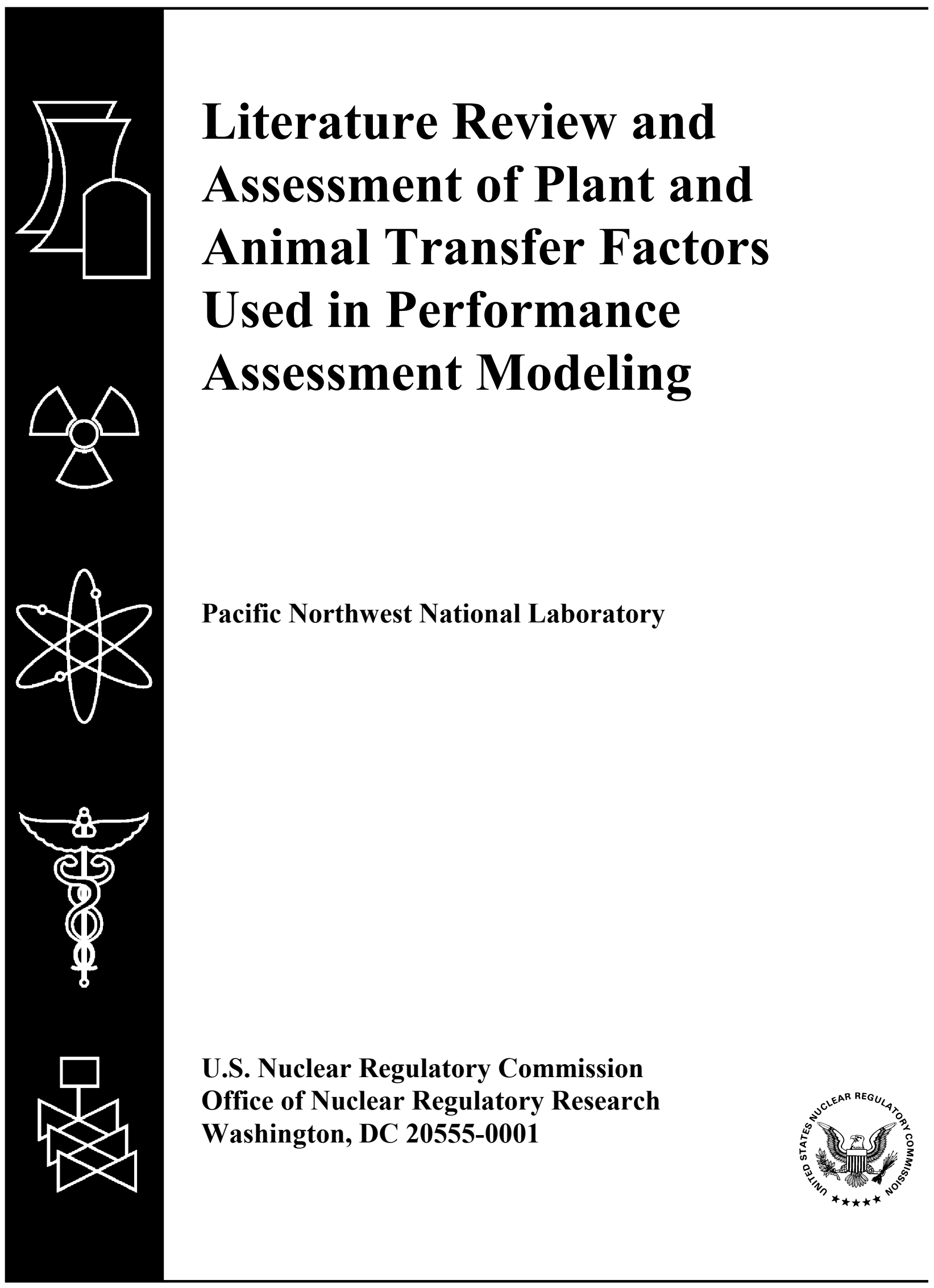




\section{Literature Review and} Assessment of Plant and Animal Transfer Factors

Used in Performance Assessment Modeling

Manuscript Completed: June 2003

Date Published: August 2003

Prepared by

D.E. Robertson, D.A. Cataldo, B.A. Napier,

K.M. Krupka, L.B. Sasser

Pacific Northwest National Laboratory

Richland, WA 99352

P.R. Reed, NRC Project Manager

Prepared for

Division of Systems Analysis and Regulatory Effectiveness

Office of Nuclear Regulatory Research

U.S. Nuclear Regulatory Commission

Washington, DC 20555-0001

NRC Job Code Y6469

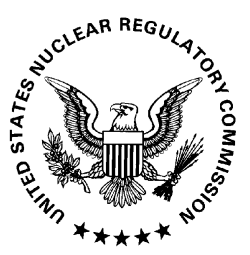




\begin{abstract}
A literature review and assessment was conducted by Pacific Northwest National Laboratory (PNNL) to update information on plant and animal radionuclide transfer factors used in performance-assessment modeling. A group of 15 radionuclides was included in this review and assessment. The review is composed of four main sections, not including the Introduction. Section 2.0 provides a review of the critically important issue of physicochemical speciation and geochemistry of the radionuclides in natural soil-water systems as it relates to the bioavailability of the radionuclides. Section 3.0 provides an updated review of the parameters of importance in the uptake of radionuclides by plants, including root uptake via the soil-groundwater system and foliar uptake due to overhead irrigation. Section 3.0 also provides a compilation of concentration ratios (CRs) for soil-to-plant uptake for the 15 selected radionuclides. Section 4.0 provides an updated review on radionuclide uptake data for animal products related to absorption, homeostatic control, approach to equilibration, chemical and physical form, diet, and age. Compiled transfer coefficients are provided for cows milk, sheeps milk, goats milk, beef, goat meat, pork, poultry, and eggs. Section 5.0 discusses the use of transfer coefficients in soil, plant, and animal modeling using regulatory models for evaluating radioactive waste disposal or decommissioned sites. Each section makes specific suggestions for future research in its area.
\end{abstract}

A compact disk (CD) is supplied with this report. The CD contains an electronic copy of this report in portable document format (PDF). The figures in this report have been printed in black and white; color versions of the figures are provided on the CD. 


\section{Contents}

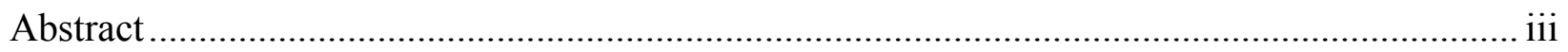

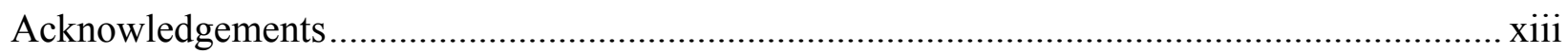

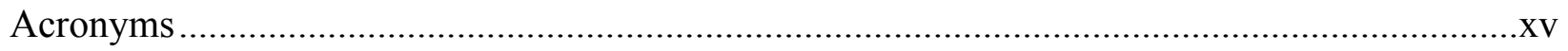

Chemical Symbols of Elements Discussed in this Report ............................................................ xvi

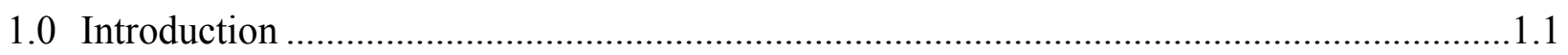

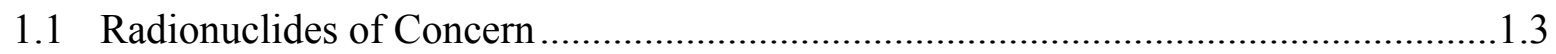

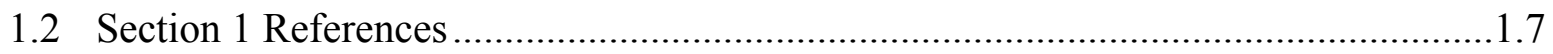

2.0 Speciation and Geochemistry of Radionuclides in Soil-Water Systems..............................2.1

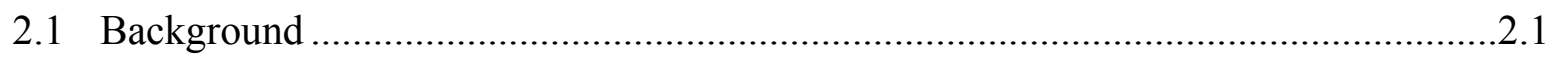

2.2 Eh-pH Species Predominance Diagrams …………………....................................... 2.5

2.3 Geochemical Processes Affecting the Mobility and Bioavailability of Selected

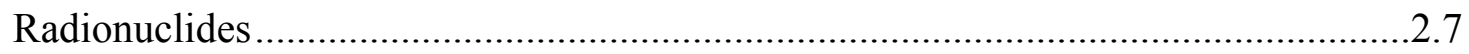

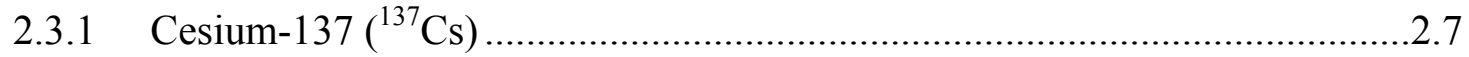

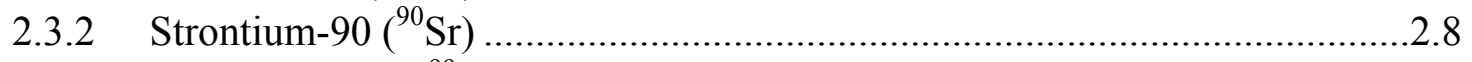

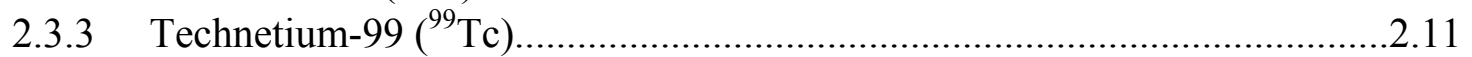

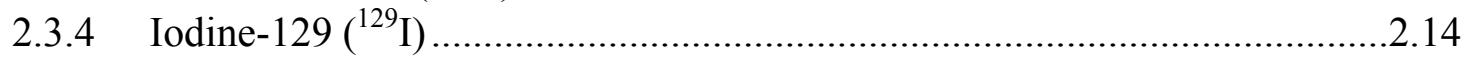

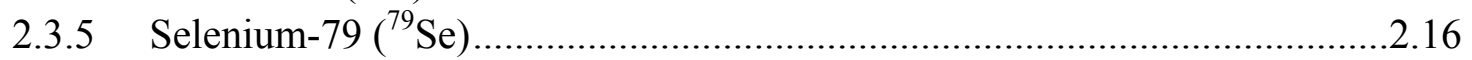

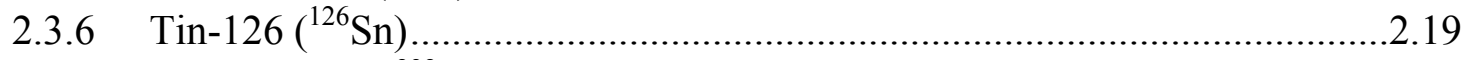

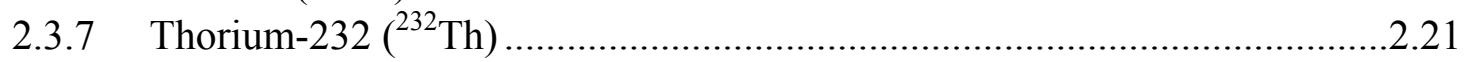

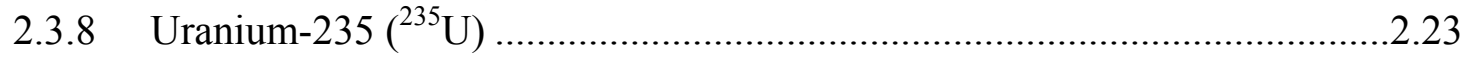

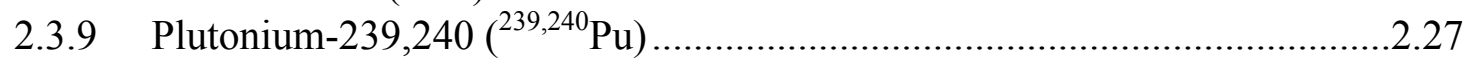

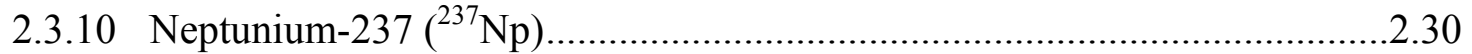

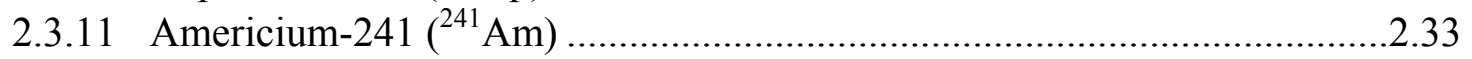

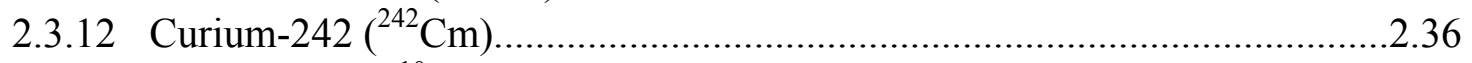

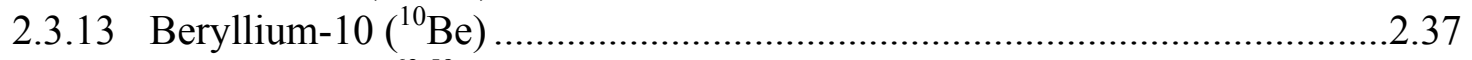

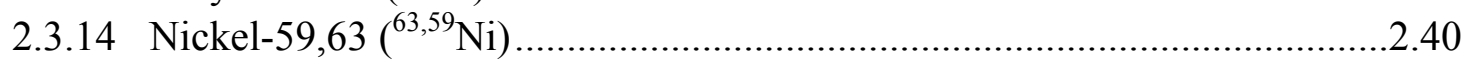

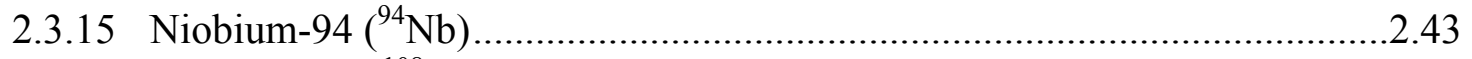

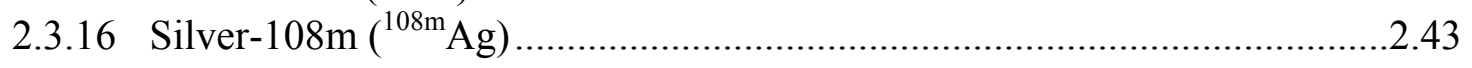

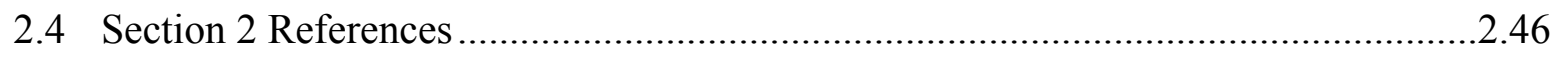




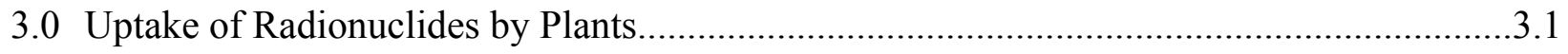

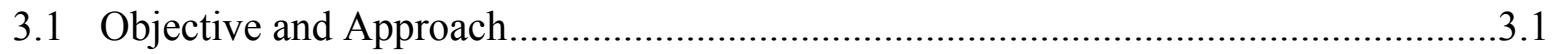

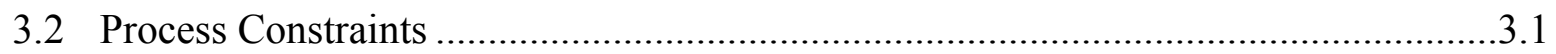

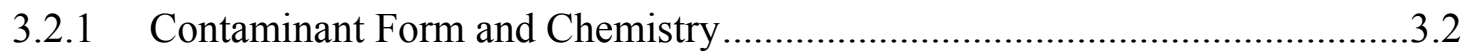

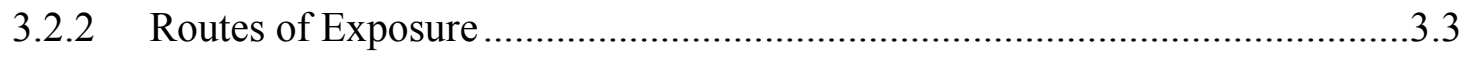

3.2.3 Biological Variables....................................................................................

3.2.4 Role of Speciation and Chemical Form/Transfer Factors and Food Chain ....3.4

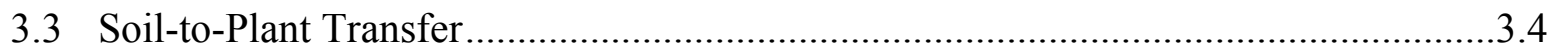

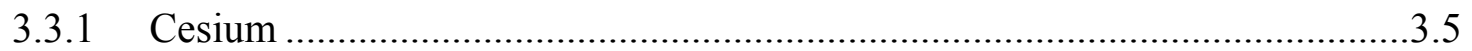

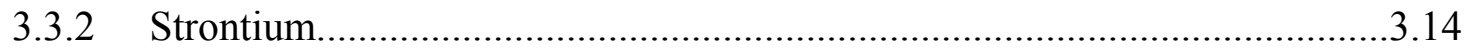

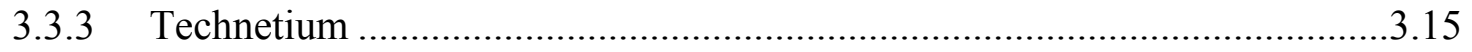

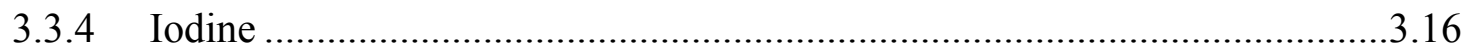

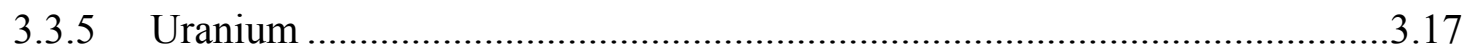

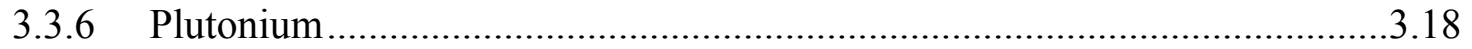

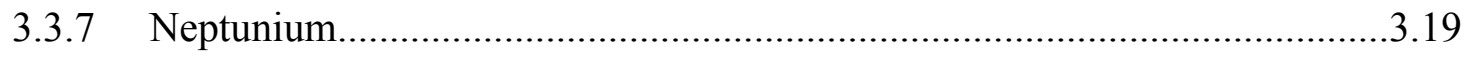

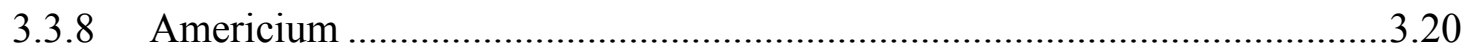

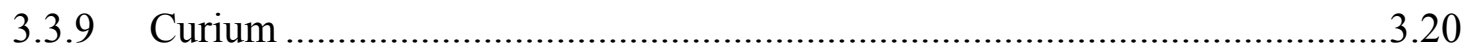

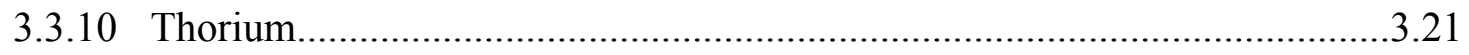

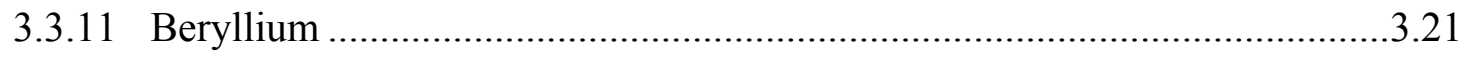

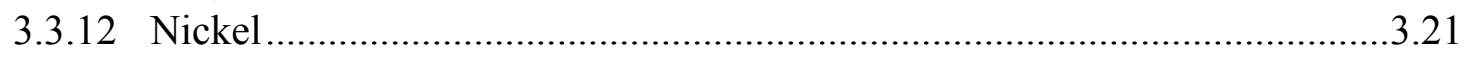

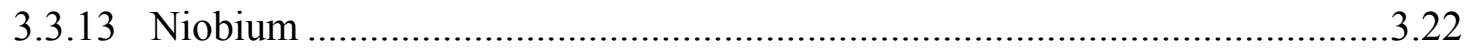

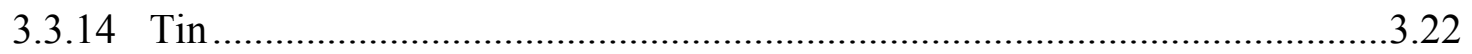

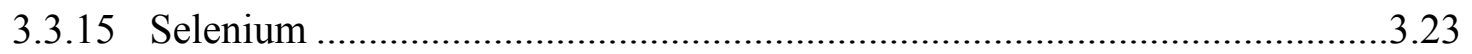

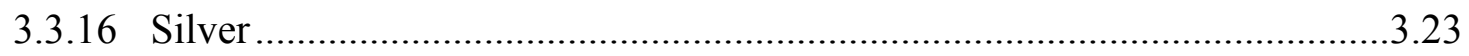

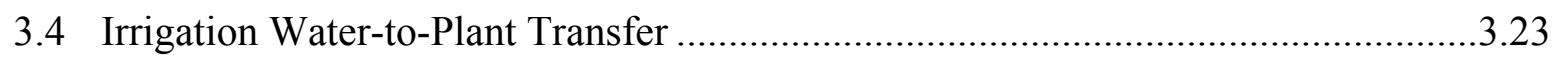

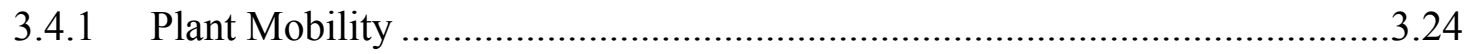

3.4.2 Potential for Foliar Absorption from Irrigation-Contaminated Surfaces.......3.25

3.4.3 Constraining Factors in Irrigation and Run-Off Processes ............................3.26

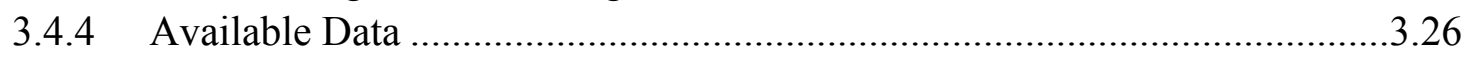

3.5 Summary of Plant Concentration Ratios, Processes, and Projected Needs ................3.27

3.5.1 Soil/Plant Concentration Ratios ...................................................................28

3.5.2 Irrigation-Water Source-Terms and Atmosphere-to-Plant Transfer...............3.28

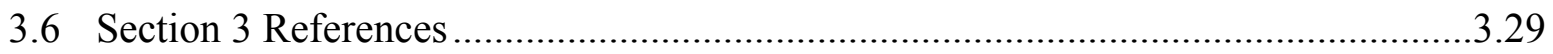

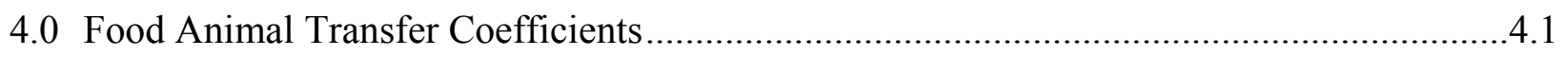

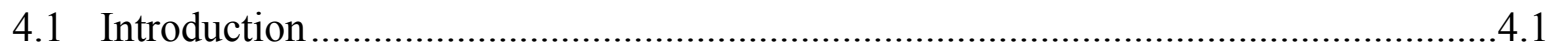




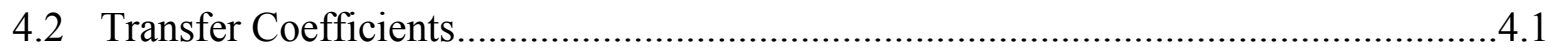

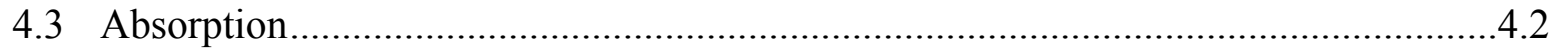

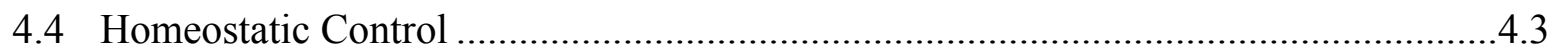

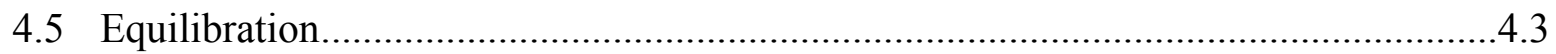

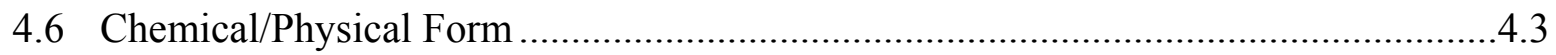

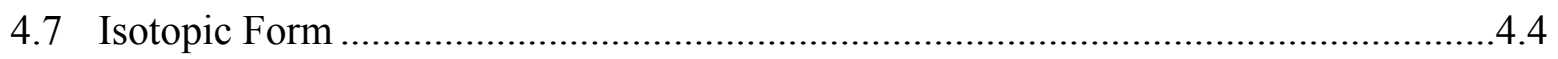

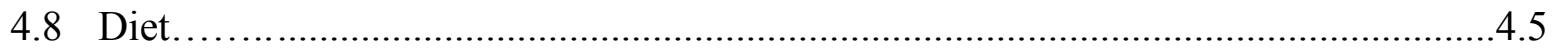

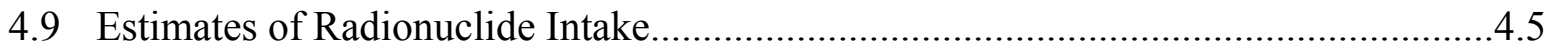

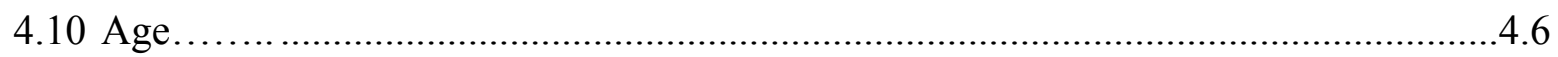

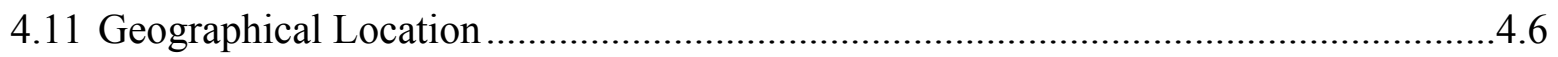

4.12 Soil and Water as Sources of Intake .....................................................................

4.13 Transfer Coefficients for Specific Radionuclides in Food-Producing Animals ..........4.8

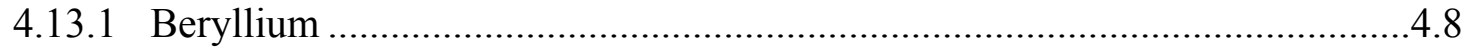

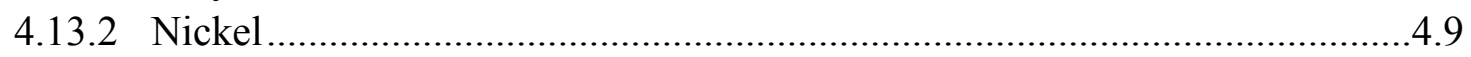

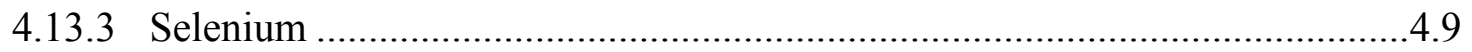

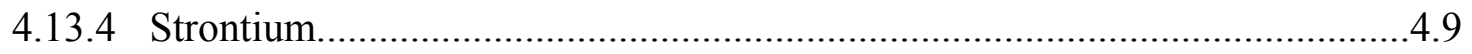

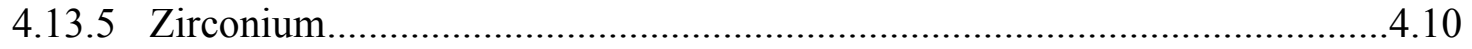

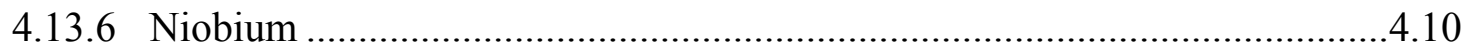

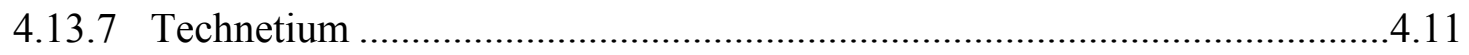

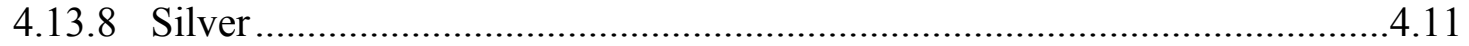

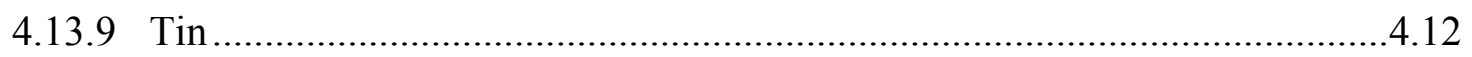

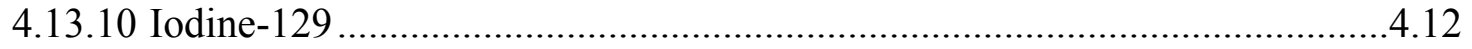

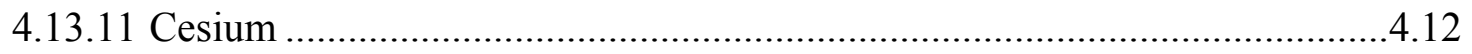

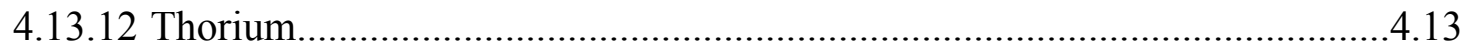

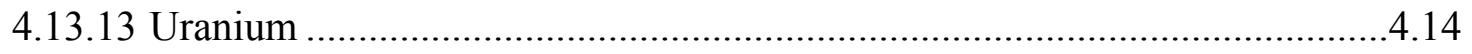

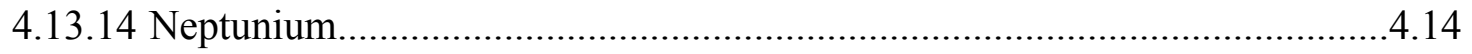

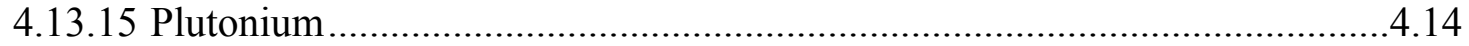

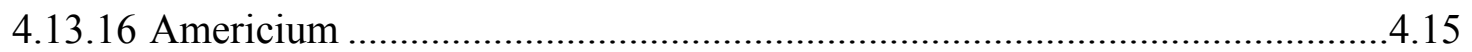

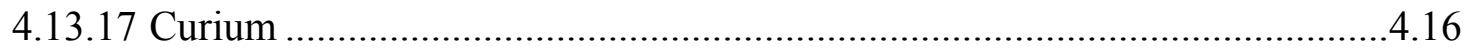

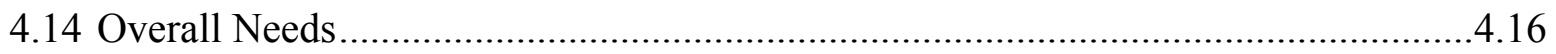

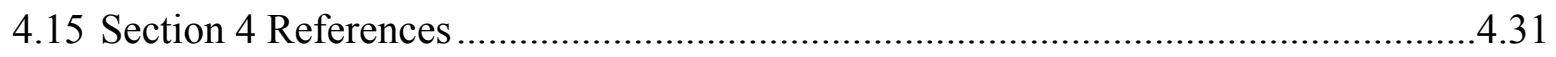


5.0 Modeling Radionuclide Behavior in Soil, Plants, and Animals

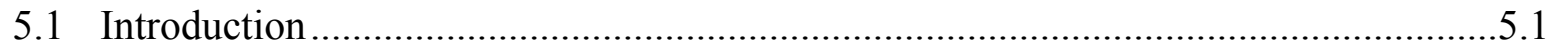

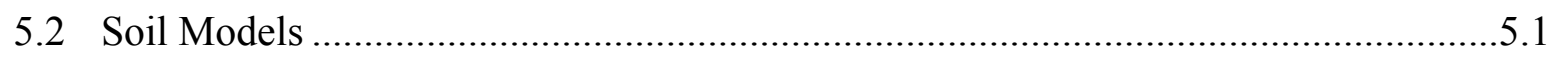

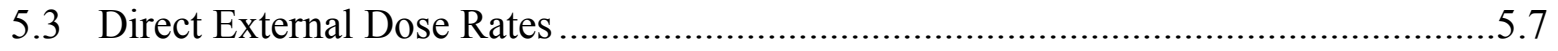

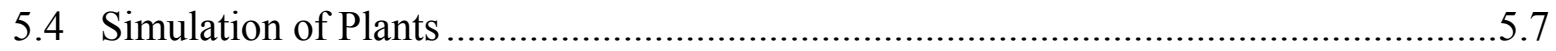

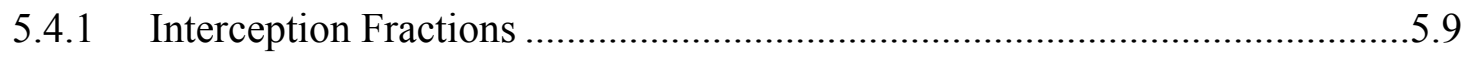

5.4.2 Contamination of Plant Surfaces with Soil ...............................................5.11

5.4.3 Weathering and Retention...................................................................... 5.12

5.4.4 Translocation from Plant Surface to Edible Portion ....................................5.12

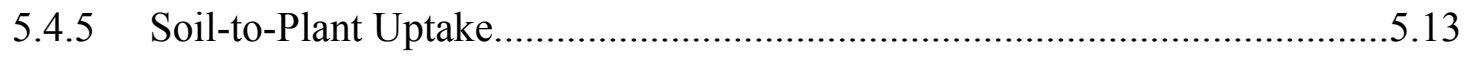

5.5 Simulation of Animal Products ........................................................................ 5.16

5.6 Sensitivity of Key Plant and Animal Parameters ............................................5.18

5.7 Recommendations Related to Modeling ........................................................... 5.18

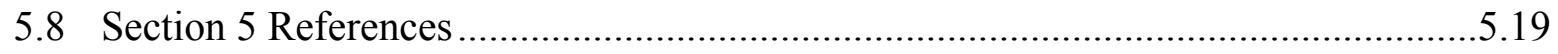




\section{List of Figures}

1.1. Change in Concentrations of Long-Lived Radionuclides in PWR Spent

Demineralizer Resin with Time

1.2. Change in Radionuclide Concentration with Time in a 304 Stainless Steel

BWR Control Rod Blade

1.3. Change in Radionuclide Concentration with Time in a PWR Control Rod

Containing Ag-Cd-In Alloy

2.1. Eh-pH Diagram Showing Dominance of Uncomplexed $\mathrm{Cs}^{+}$Aqueous Species ...............2.8

2.2. Eh-pH Diagram Showing Dominant Aqueous Species of Strontium

2.3. Diagram Showing Eh-pH Region (tan colored) that Calculates to be Oversaturated with Respect to the Solubility of Strontianite $\left(\mathrm{SrCO}_{3}\right)$

2.4. Eh-pH Diagram Showing Dominant Aqueous Species of Technetium

2.5. Diagram Showing Eh-pH Region (Tan Colored) that Calculates to be Oversaturated with Respect to the Solubility of Technetium Solids....

2.6. Eh-pH Diagram Showing Dominant Aqueous Species of Iodine

2.7. Eh-pH Diagram Showing Dominant Aqueous Species of Selenium

2.8. Diagram Showing Eh-pH Region (tan colored) that Calculates to be Oversaturated with Respect to the Solubility of Elemental Selenium.

2.9. Eh-pH Diagram Showing Dominant Aqueous Species of Tin.

2.10. Diagram Showing Eh-pH Region (Tan Colored) that Calculates to be Oversaturated with Respect to the Solubility of Tin Solids

2.11. Eh-pH Diagram Showing Dominant Aqueous Species of Thorium

2.12. Diagram Showing Eh-pH Region (tan colored) that Calculates to be Oversaturated with Respect to the Solubility of Thorianite $\left(\mathrm{ThO}_{2}\right)$

2.13. Eh-pH Diagram Showing Dominant Aqueous Species of Uranium.

2.14. Diagram Showing Eh-pH Region (tan colored) that Calculates to be Oversaturated with Respect to the Solubility of Uraninite $\left(\mathrm{UO}_{2}\right)$ .26

2.15. Eh-pH Diagram Showing Dominant Aqueous Species of Plutonium 2.28 
2.16. Diagram Showing Eh-pH Region (tan colored) that Calculates to be Oversaturated with Respect to the Solubility of $\mathrm{PuO}_{2}$

2.17. Eh-pH Diagram Showing Dominant Aqueous Species of Neptunium

2.18. Diagram Showing Eh-pH Region (Tan Colored) that Calculates to be Oversaturated with Respect to the Solubility of Neptunium Solids

2.19. Eh-pH Diagram Showing Dominant Aqueous Species of Americium.

2.20. Diagram Showing Eh-pH Region (tan colored) that Calculates to be Oversaturated with Respect to the Solubility of Americium Solids

2.21. Eh-pH Diagram Showing Dominant Aqueous Species of Beryllium

2.22. Diagram Showing Eh-pH Region (Tan Colored) that Calculates to be Oversaturated with Respect to the Solubility of Bromellite $(\mathrm{BeO})$

2.23. Eh-pH Diagram Showing Dominant Aqueous Species of Nickel

2.24. Diagram Showing Eh-pH Region (Tan Colored) that Calculates to be Oversaturated with Respect to the Solubility of Nickel Solids

2.25. Eh-pH Diagram Showing Dominant Aqueous Species of Silver.

2.26. Diagram Showing Eh-pH Region (tan colored) that Calculates to be Oversaturated with Respect to the Solubility of Acanthite $\left(\mathrm{Ag}_{2} \mathrm{~S}\right)$

5.1. Generic Model for Radionuclide Transport in Surface Soils ..............................................5.2

5.2. More Complex Soil Model.......................................................................................

5.3. Idealized Behavior of Radionuclide Concentration in Soil Following Long Periods of Irrigation for Mobile and Immobile Radionuclides

5.4. A Basic Model for Contamination of Plants .5 .8 


\section{List of Tables}

1.1. Properties of Radionuclides of Potential Concern ..................................................... 1.4

2.1. Summary of Chemical Processes Affecting the Mobility of Radionuclides....................2.2

2.2. Composition of Groundwater Used for Aqueous Speciation Calculations......................2.6

3.1. Compiled Soil/Plant and Foliar Deposition References ............................................

3.2. Mobility of Essential Elements in the Phloem of Plants, and Projected Analogue/Non Nutrient Ion Behavior ....................................................................... 3.25

3.3. Probable Bioavailability/Cuticular Transfer of Selected Elements .................................26

4.1. Radionuclide Transfer Coefficients for Cow Milk .................................................4.18

4.2. Radionuclide Transfer Coefficients for Sheep Milk ...............................................4.21

4.3. Radionuclide Transfer Coefficients for Goat Milk ................................................4.22

4.4. Radionuclide Transfer Coefficients for Beef ........................................................23

4.5. Radionuclide Transfer Coefficients for Mutton and Lamb.......................................4.25

4.6. Transfer Coefficients for Goat Meat ........................................................................ 4.27

4.7. Radionuclide Transfer Coefficients for Pork ...................................................... 4.28

4.8. Radionuclide Transfer Coefficients for Poultry ...................................................4.29

4.9. Radionuclide Transfer Coefficients for Eggs....................................................4.30

5.1. Harvested Yield, Standing Biomass, and Ratio of Dry to Wet Vegetation Used in Interception and Harvest Removal Models 


\section{Acknowledgements}

The authors are particularly grateful for the technical guidance, review, and encouragement provided by Phillip R. Reed of the U.S. Nuclear Regulatory Commission. The authors wish to express their appreciation to Wayne C. Cosby for editorial and word-processing assistance. 


\section{Acronyms}

ANDRA French national radioactive waste management agency

BDCF biosphere dose conversion factor

BNL Brookhaven National Laboratory

BPRA burnable poison rod assemblies

BWR boiling-water reactor

CD compact disk

CEC cation exchange capacity

CIS Confederation of Independent States

CR concentration ratio

CRB control rod blade

EDTA ethylenediaminetetraacetic acid

EPA U.S. Environmental Protection Agency

GSD geometrical standard deviation

HLW high-level waste

IAEA International Atomic Energy Agency

IAEA/IUR International Atomic Energy Agency/International Union of Radioecologists

INEL Idaho National Engi neering Laboratory

LAI leaf area index

LANL Los Alamos National Laboratory

LLNL Lawrence Livermore National Laboratory

LLW low-level radioactive waste

MMAD mass median aerodynamic diameter

NAS National Academy of Sciences

NCRP National Council on Ionizing Radiation and Protection

NRC U.S. Nuclear Regulatory Commission

NRC/RES U.S. Nuclear Regulatory Commission/Office of Nuclear Regulatory Research

O-R observed ratio

PA performance assessment

PDF portable document format

PNNL Pacific Northwest National Laboratory 


$\begin{array}{ll}\text { ppm } & \text { parts per million } \\ \text { PWR } & \text { pressurized-water reactor } \\ \text { PZC } & \text { point-of-zero charge } \\ \text { redox } & \text { oxidation/reduction } \\ \text { SAC } & \text { System Assessment Capability } \\ \text { TEDE } & \text { total effective dose equivalent } \\ \text { UK } & \text { United Kingdom } \\ \text { ZPC } & \text { zero point of charge }\end{array}$

\section{Chemical Symbols of Elements Discussed in this Report}

(Note: Elements have been written out in full in text except where the symbols are appropriate or more useful. Abbreviations are used in tables, in cases where isotopes or chemical formulas are used, and in long lists of elements.)

$\begin{array}{ll}\mathrm{Ag} & \text { silver } \\ \mathrm{Am} & \text { americium } \\ \mathrm{Be} & \text { beryllium } \\ \mathrm{Ca} & \text { calcium } \\ \mathrm{Ce} & \text { cerium } \\ \mathrm{Cm} & \text { curium } \\ \mathrm{Cs} & \text { cesium } \\ \mathrm{I} & \text { iodine } \\ \mathrm{K} & \text { potassium } \\ \mathrm{Mg} & \text { magnesium } \\ \mathrm{Mn} & \text { manganese } \\ \mathrm{Ni} & \text { nickel } \\ \mathrm{Pu} & \text { plutonium } \\ \mathrm{Se} & \text { selenium } \\ \mathrm{Sn} & \text { tin } \\ \mathrm{Tc} & \text { technetium } \\ \mathrm{U} & \text { uranium } \\ \mathrm{Zn} & \text { zinc } \\ \mathrm{Zr} & \text { zirconium }\end{array}$




\subsection{Introduction}

In the Nuclear Regulatory Commission's (NRC's) performance assessments, biosphere analysis provides the means to predict the total effective dose equivalent (TEDE) to persons living in the vicinity of waste-disposal facilities and decommissioning sites, assuming a gradual release of radionuclides over time to the biosphere after the waste-disposal facilities and decommissioned sites are closed. To assess the dose to individuals living near these sites, NRC's biosphere analyses include sophisticated evaluations of the food-chain pathway for potential radionuclide contamination that includes irrigation processes involved in the contamination of crops and forage with contaminated groundwater, soil mechanisms involved with both radionuclide transfers to the roots of vegetation and resuspension of contaminated soil onto plant leaves, and the location, lifestyles, and dietary habits of potentially exposed individuals.

The biosphere model is the last model in a series of models used by the NRC staff in performance assessments of waste-disposal facilities and decommissioning sites. The biosphere models used by the NRC staff in its performance assessments are based on conceptual models, their mathematical representation, and the implementing computer codes. The NRC's biosphere models, and their implementing computer codes, include hypotheses, assumptions, and simplifications that describe the reference biosphere in the vicinity of the waste-disposal facilities and decommissioning sites. The NRC staff uses the GENII-S biosphere computer codes (Leigh et al. 1992) in high-level and low-level waste-performance assessments. A newer version of this code, GENII Version 2 (Napier et al. 2003), is undergoing beta testing by the scientific community. Similar biosphere models are incorporated in the decommissioning performance-assessment codes RESRAD (Yu et al. 2002) and DandD (McFadden et al. 2001). These computer codes consider (1) radionuclide transport through many food-chain pathways such as irrigation-water deposition on vegetation and soil surfaces, (2) crop interception and retention, (3) radionuclide buildup in soils as a result of long-term irrigation deposition, (4) soil radionuclide leaching and retention mechanisms in plant root zones, (5) resuspension of radionuclide-contaminated soil onto vegetation, (6) soil to plant uptake via roots, (7) feed-toanimal product transfer, and (8) individual food product consumption rates.

The desire to provide realistic analyses of long-term performance of waste-disposal facilities and decommissioning sites leads to a need for more sophisticated food-chain analyses. As attention has focused on more realistic exposure scenarios, the data used in the biosphere pathway models have drawn attention because many parameter values are based on data of questionable quality or limited utility. A research program is underway to provide a comprehensive literature review that includes experimental and analytical results for the parameters needed by NRC staff for use in biosphere models and computer codes. This report summarizes the detailed literature review undertaken as the first step in this program.

For this literature review and assessment study, the U.S. Nuclear Regulatory Commission/Office of Nuclear Regulatory Research (NRC/RES) provided a list of 17 long-lived radionuclides for consideration in developing an updated database of plant and animal radionuclide transfer factors for use in dose-assessment modeling codes. These radionuclides are listed in Section 2.1. 
Section 2 of this report also discusses factors the control geochemical transport processes, such as aqueous complexation, oxidation/reduction (redox), adsorption/desorption and ion exchange, precipitation/dissolution, diffusion, colloid-facilitated transport, and anion exclusion. Thumbnail sketches are provided of the key geochemical processes affecting the mobility and bioavailability of each of the selected radionuclides in soils. Results are presented graphically for most contaminants of interest.

Section 3 reviews the pertinent available literature on soil-to-plant uptake for specific radionuclides, including chemical analogues where necessary, and attempts to rationalize the normal variability imposed by both physicochemical and biotic processes on bioavailability and speciation, and thus their overall behavior with respect to risk. The review is limited to terrestrial systems; specifically, source terms that include soils, and where possible, irrigation waters and catastrophic geological events. The literature on the transfer of contaminants initially deposited on plant surfaces by irrigation water to more distant portions of the plant is also reviewed. Results are provided in tabular format.

Section 4 reports on a literature review performed on radionuclide uptake data for animal products. For this task, transfer coefficients were reviewed, evaluated, and compiled for cow milk, sheep milk, goat milk, beef, goat meat, pork, poultry, and eggs. The emphasis of this review was on transfer coefficients from primary animal experiments that provided data from which transfer coefficients have been developed. The factors that influence the uptake of radionuclides into animal products related to absorption, homeostatic control, approach to equilibration, chemical and physical form, diet, and age are summarized. Results are provided in tabular format.

Section 5 discusses the use of transfer coefficients in soil, plant, and animal modeling using regulatory models for evaluating radioactive waste disposal or decommissioned sites. For such models, the dynamics of most processes are unimportant, and only the integral or average exposure is estimated. In general, models used for predicting future behavior are applied to situations where conditions change slowly, and annual average modeling is appropriate.

Each section makes specific suggestions for future research in its area. The research results are expected to be useful in:

- supporting the development of regulatory criteria (e.g., guidance, technical positions) for food-chain pathway issues involving biosphere models

- providing a basis for evaluating and auditing an applicant's or licensee's biosphere and foodchain pathway data, information, analyses, conceptual models, and computer codes used in license submittals

- providing a database of experimental data, scientific information, and scientific expertise to substantiate margins of or to quantify uncertainties in the technical basis for licensing 
- providing NRC staff with data and information for resolving biosphere issues involving irrigation pathways, food and animal transfer factors, and groundwater radionuclide release scenarios.

The results of the research program improve the NRC staff's understanding of the plant-to-soil concentration ratios and animal-transfer coefficients obtained for some important long-lived radionuclides in biosphere modeling of the performance-assessment process.

\subsection{Radionuclides of Concern}

The various types of radioactive waste presently being disposed of, or considered for future underground disposal, contain hundreds of radionuclides. However, only a few long-lived radionuclides will have any significant potential radiation-dose impact on the environs should they escape from a repository. Previous attempts to consider and prioritize radionuclide constituents of concern for waste disposal site licensing and performance assessment modeling have focused on 10 to 26 long-lived radionuclides that would potentially contribute to the offsite radiation dose (Eslinger et al. 1993; 54 FR 22578; LaPlante et al. 1996; LaPlant and Poor 1997; Wescott et al. 1995; Wilson et al. 2002).

For this literature review and assessment study, NRC/RES provided a list of some 17 long-lived radionuclides for consideration in developing an updated database of plant and animal radionuclide transfer factors for use in dose-assessment modeling codes. These radionuclides are listed in Table 1.1, together with some of their important nuclear and waste-management properties. The list is a good representation of the radioelements referred to in the above citations of radionuclides of concern from low-level and high-level waste considerations, and includes all of those well-known radionuclides shown in prior performance-assessment modeling of waste repositories to be of greatest concern from an offsite radiation dose consideration. Other radionuclides, such as ${ }^{10} \mathrm{Be}$ and ${ }^{108 \mathrm{~m}} \mathrm{Ag}$, have recently been measured in significant concentrations in spent reactor-control-rod waste materials (Robertson et al. 2000), but very little is known about their environmental behavior.

Radionuclides of potential concern include the following:

- long-lived fission products having relatively high to moderate waste inventories and high to moderate environmental mobilities $\left({ }^{99} \mathrm{Tc},{ }^{129} \mathrm{I},{ }^{79} \mathrm{Se},{ }^{126} \mathrm{Sn}\right)$

- transuranic radionuclides of relatively high waste inventories and ingestion dose conversion factors $\left({ }^{239,240} \mathrm{Pu},{ }^{241} \mathrm{Am},{ }^{242} \mathrm{Cm},{ }^{237} \mathrm{~Np}\right)$

- long-lived neutron-activation products contained in irradiated reactor waste materials, such as spent fuel disassembly hardware, spent control rods, reactor internals, and spent primary coolant demineralizer resin $\left({ }^{10} \mathrm{Be},{ }^{14} \mathrm{C},{ }^{59,63} \mathrm{Ni},{ }^{94} \mathrm{Nb},{ }^{108 \mathrm{~m}} \mathrm{Ag}\right)$

- naturally-occurring actinide radionuclides having relatively high waste inventories $\left({ }^{235,238} \mathrm{U}\right.$, $\left.{ }^{232} \mathrm{Th}\right)$. 
Table 1.1. Properties of Radionuclides of Potential Concern

\begin{tabular}{|c|c|c|c|c|c|}
\hline Radionuclide & $\begin{array}{c}\text { Half-Life } \\
\text { (Years) }\end{array}$ & $\begin{array}{c}\text { Decay Mode } \\
\text { (Type, Energy) }\end{array}$ & $\begin{array}{c}\text { Waste } \\
\text { Inventory }\end{array}$ & $\begin{array}{l}\text { Environ. } \\
\text { Mobility }\end{array}$ & $\begin{array}{c}\text { Ingestion Dose } \\
\text { Conversion } \\
\text { Factor (Sv/Bq) }\end{array}$ \\
\hline${ }^{99} \mathrm{Tc}$ & 213,000 & $\beta^{-}, 294 \mathrm{keV}$ & High & High & $3.95 \mathrm{E}-10$ \\
\hline${ }^{129} \mathrm{I}$ & $1.57 \mathrm{E}+7$ & $\begin{array}{l}\beta^{-}, 150 \mathrm{keV} \\
\gamma 39.6 \mathrm{keV}\end{array}$ & Low & High & $7.46 \mathrm{E}-8$ \\
\hline${ }^{14} \mathrm{C}$ & 5,715 & $\beta^{-}, 157 \mathrm{keV}$ & Moderate & High & $5.64 \mathrm{E}-10$ \\
\hline${ }^{79} \mathrm{Se}$ & 650,000 & $\beta^{-}, 160 \mathrm{keV}$ & Moderate & Moderate & $2.35 \mathrm{E}-9$ \\
\hline${ }^{126} \mathrm{Sn}$ & 250,000 & $\begin{array}{l}\beta^{-}, 250 \mathrm{keV} \\
\gamma 87.6 \mathrm{keV}\end{array}$ & Moderate & Low & $5.27 \mathrm{E}-9$ \\
\hline${ }^{232} \mathrm{Th}$ & $1.4 \mathrm{E}+12$ & $\alpha 4012 \mathrm{keV}$ & NORM & Low & $7.38 \mathrm{E}-7$ \\
\hline${ }^{238} \mathrm{U}$ & $\begin{array}{l}7.04 \mathrm{E}+8 \\
4.47 \mathrm{E}+9\end{array}$ & $\begin{array}{l}\alpha 7040 \mathrm{keV} \\
\alpha 4197 \mathrm{keV}\end{array}$ & High & Low & $\begin{array}{l}7.19 \mathrm{E}-8 \\
6.88 \mathrm{E}-8\end{array}$ \\
\hline $\begin{array}{l}{ }^{239} \mathrm{Pu} \\
{ }^{240} \mathrm{Pu}\end{array}$ & $\begin{array}{c}24,100 \\
6537\end{array}$ & $\begin{array}{l}\alpha 5156 \mathrm{keV} \\
\alpha 5168 \mathrm{keV}\end{array}$ & High & Low & $9.56 \mathrm{E}-7$ \\
\hline${ }^{237} \mathrm{~Np}$ & $2.14 \mathrm{E}+6$ & $\alpha 4788$ & High & Moderate & $1.20 \mathrm{E}-6$ \\
\hline${ }^{241} \mathrm{Am}$ & 432.7 & $\begin{array}{l}\alpha 5486 \mathrm{keV} \\
\gamma 59.9 \mathrm{keV}\end{array}$ & High & Low & $9.84 \mathrm{E}-7$ \\
\hline${ }^{242} \mathrm{Cm}$ & 0.446 & $\alpha 6113 \mathrm{keV}$ & Moderate & Low & $3.10 \mathrm{E}-8$ \\
\hline${ }^{10} \mathrm{Be}$ & $1.5 \mathrm{E}+6$ & $\beta^{-}, 556 \mathrm{keV}$ & $\begin{array}{l}\text { Moderate } \\
\text { in CRB }\end{array}$ & Low & $1.26 \mathrm{E}-9$ \\
\hline $\begin{array}{l}{ }^{59} \mathrm{Ni} \\
{ }^{63} \mathrm{Ni}\end{array}$ & $\begin{array}{c}76,000 \\
100\end{array}$ & $\begin{array}{l}\mathrm{EC}, 6.9 \mathrm{keV} \\
\beta^{-}, 66.9 \mathrm{keV}\end{array}$ & $\begin{array}{l}\text { High in } \\
\text { act. metals }\end{array}$ & Low & $\begin{array}{l}5.67 \mathrm{E}-11 \\
1.56 \mathrm{E}-10\end{array}$ \\
\hline${ }^{94} \mathrm{Nb}$ & 20,000 & $\begin{array}{c}\beta^{-}, 473 \mathrm{keV} \\
\gamma 703 ; 871 \mathrm{keV}\end{array}$ & Moderate & Low & $1.93 \mathrm{E}-9$ \\
\hline${ }^{108 m} \mathrm{Ag}$ & 130 & $\begin{array}{c}\mathrm{EC} / \beta^{+} \\
\gamma 723 ; 434 ; 614\end{array}$ & $\begin{array}{l}\text { High in } \\
\text { CR alloys }\end{array}$ & Low & $2.09 \mathrm{E}-9$ \\
\hline
\end{tabular}

Most of the long-lived fission product, transuranic, and actinide radionuclides of concern have been studied to varying degrees with respect to their environmental mobility and biological uptake. However, several radionuclides that have not been previously considered in radioactive waste management and disposal site performance assessments deserve special explanation for including them in this literature review and assessment.

Only recently have ${ }^{10} \mathrm{Be}$ and ${ }^{108 \mathrm{~m}} \mathrm{Ag}$ been shown to be present in significant concentrations in spent reactor control rod materials and other types of low-level waste (Robertson et al. 2000), and further performance assessment modeling of the risk and dose need to be conducted to determine if they should be given further consideration from a waste-disposal standpoint. Beryllium-10 is a very long-lived (1.6 million year half-life) radionuclide that is a pure beta emitter (556 keV max.). It can be produced by a variety of nuclear reactions, but for nuclear power plant low-level waste, the ${ }^{10} \mathrm{~B}(\mathrm{n}, \mathrm{p}){ }^{10} \mathrm{Be}$ reaction is the most important because the parent isotope, ${ }^{10} \mathrm{~B}$, is present in spent boiling-water reactor (BWR) control rod blades as boron carbide 
$\mathrm{z}\left(\mathrm{B}_{4} \mathrm{C}\right)$ and in spent pressurized-water reactor (PWR) burnable poison rod assemblies (BPRAs) as borosilicate glass. Soluble boron is used as a chemical reactivity shim in PWR primary coolant at concentrations of up to several thousand parts per million (ppm) of boron. Therefore, ${ }^{10} \mathrm{Be}$ can be produced from the ${ }^{10} \mathrm{~B}$ in control-rod assemblies and in PWR primary coolant. Once the ${ }^{10} \mathrm{Be}$ is produced in the primary coolant, it is capable of then entering into most of the lowlevel waste streams generated at nuclear power stations, e.g., primary demineralizer resins, filters, sludges, and evaporator bottoms. Figure 1.1 shows the change in relative concentration of ${ }^{10} \mathrm{Be}$ with decay time in PWR spent primary demineralizer resin. This figure indicates that after about 100 years, ${ }^{10} \mathrm{Be}$ will be the third most abundant radionuclide in the waste resin.

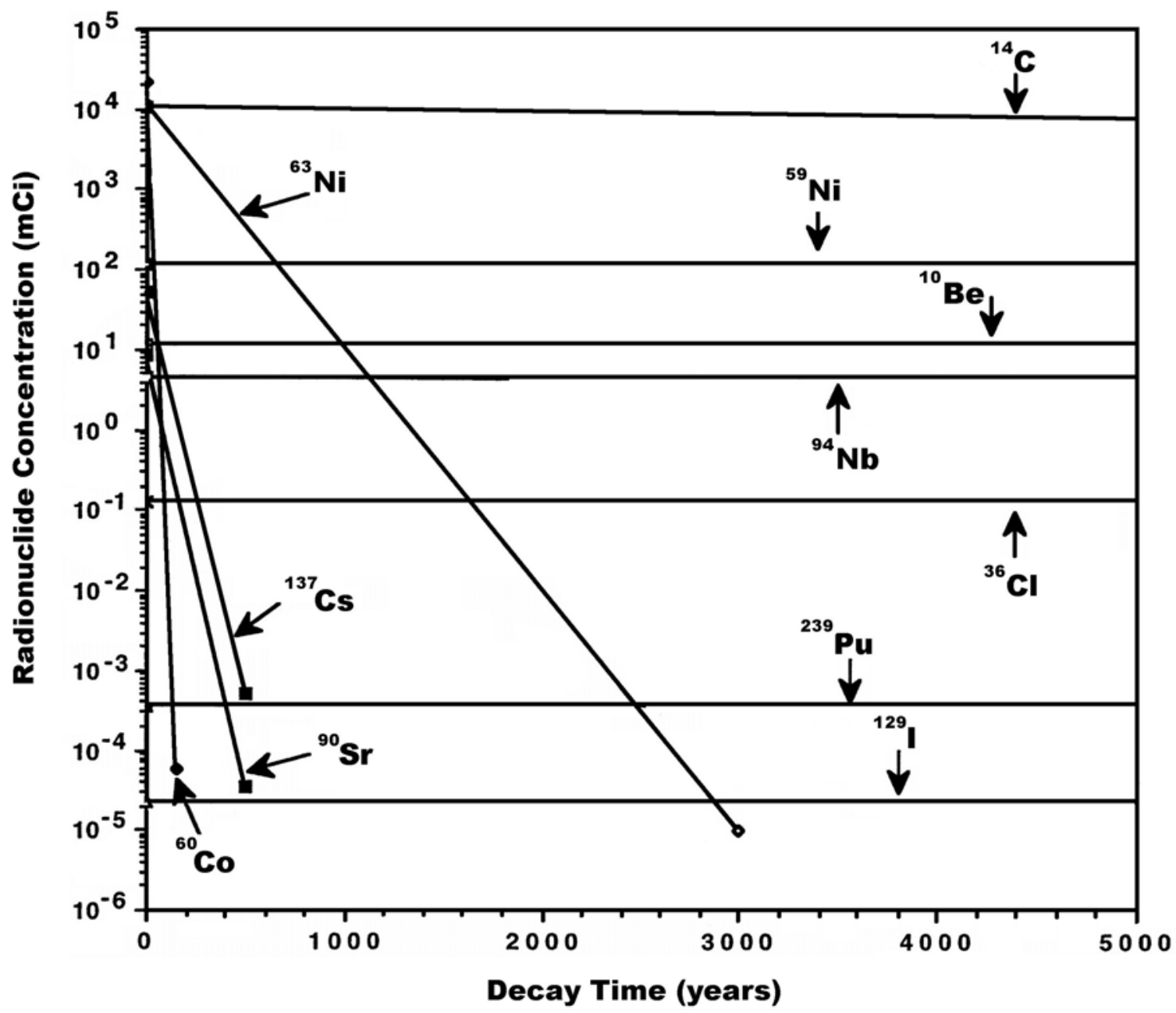

Figure 1.1. Change in Concentrations of Long-Lived Radionuclides in PWR Spent Demineralizer Resin with Time. (After 100 years, ${ }^{10} \mathrm{Be}$ will be the third most abundant radionuclide in the waste resin.)

Figure 1.2 shows the change in concentration with time of long-lived radionuclides in a spent BWR stainless steel control rod blade (CRB). This figure shows that after about 100 years of decay time, ${ }^{10} \mathrm{Be}$ will be the third most abundant radionuclide in the $\mathrm{CRB}$, and after several thousand years, it will be second only to ${ }^{59} \mathrm{Ni}$ in abundance. It is obvious from its relatively high 
abundance in certain types of low-level waste that ${ }^{10} \mathrm{Be}$ deserves an inventory and environmental behavior assessment to determine if it would significantly contribute to the offsite dose at a radioactive waste disposal facility.

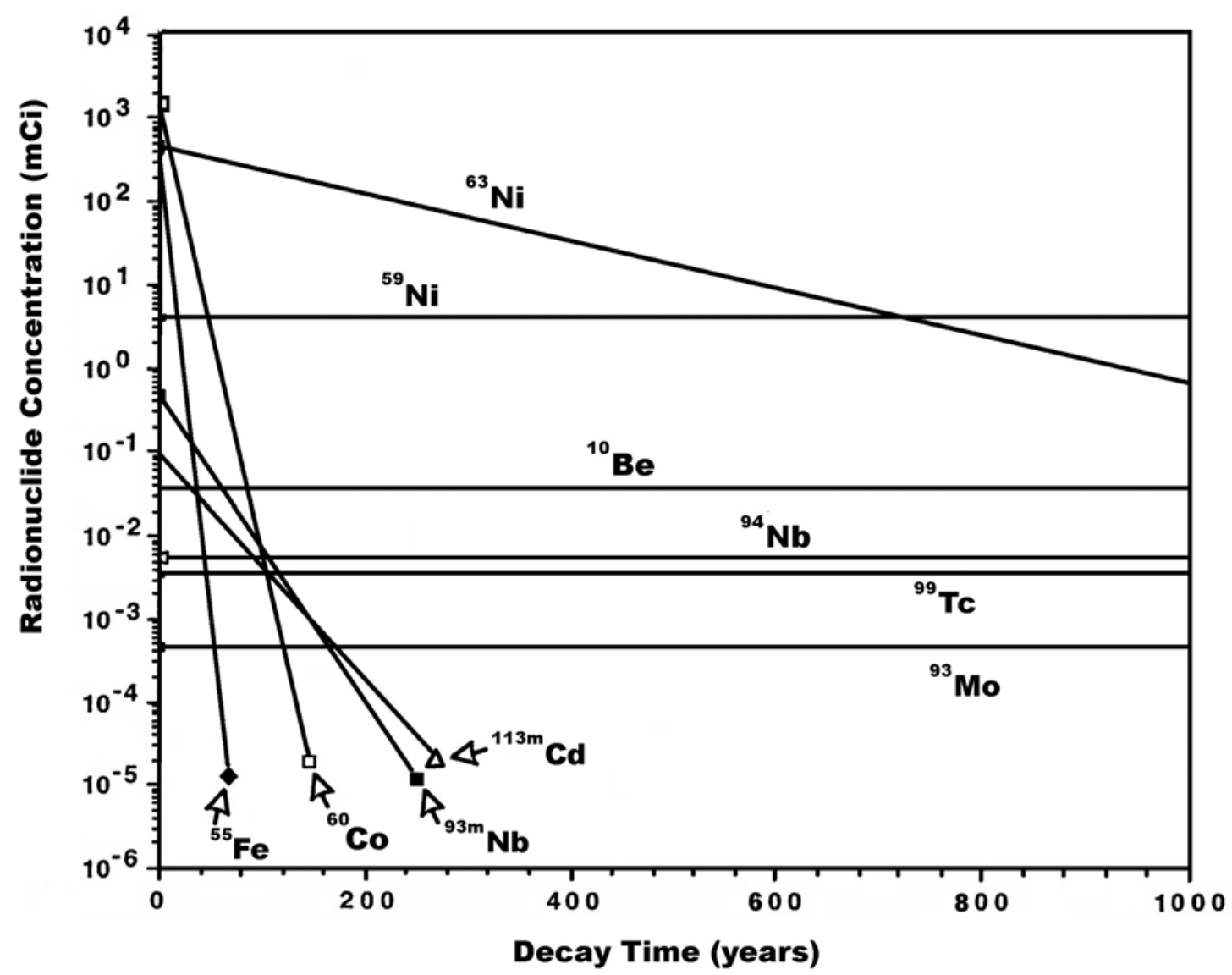

Figure 1.2. Change in Radionuclide Concentration with Time in a 304 Stainless Steel BWR Control Rod Blade. (After about 100 years ${ }^{10}$ Be will be the third most abundant radionuclide in the control rod.)

Another long-lived radionuclide that deserves further assessment from a radiation-dose consideration is ${ }^{108 \mathrm{~m}} \mathrm{Ag}$. Silver- $108 \mathrm{~m}$ is a 130 -year half-life radionuclide produced by the thermal neutron activation reaction, ${ }^{107} \mathrm{Ag}(\mathrm{n}, \gamma){ }^{108 \mathrm{~m}} \mathrm{Ag}$. Silver is present at a concentration of $80 \%$ in the Ag-Cd-In alloy used in PWR control rod assemblies. Therefore, ${ }^{108 \mathrm{~m}} \mathrm{Ag}$ is a major constituent of these types of control rod assemblies that are gradually being replaced at PWR stations and is many orders of magnitude higher in concentrations than the other activation products present in these spent control rods (see Figure 1.3). The ${ }^{108 \mathrm{~m}} \mathrm{Ag}$ decays with the emission of several high-energy gamma rays (434, 614, and $723 \mathrm{keV})$ and therefore has a relatively high curie-to-dose conversion factor. Silver-108m is generally not present in significant concentrations in other types of low-level waste normally generated at commercial nuclear power stations, but its high concentrations in spent PWR control rods justifies a further assessment of its potential waste inventory and its environmental and biological uptake behavior. 


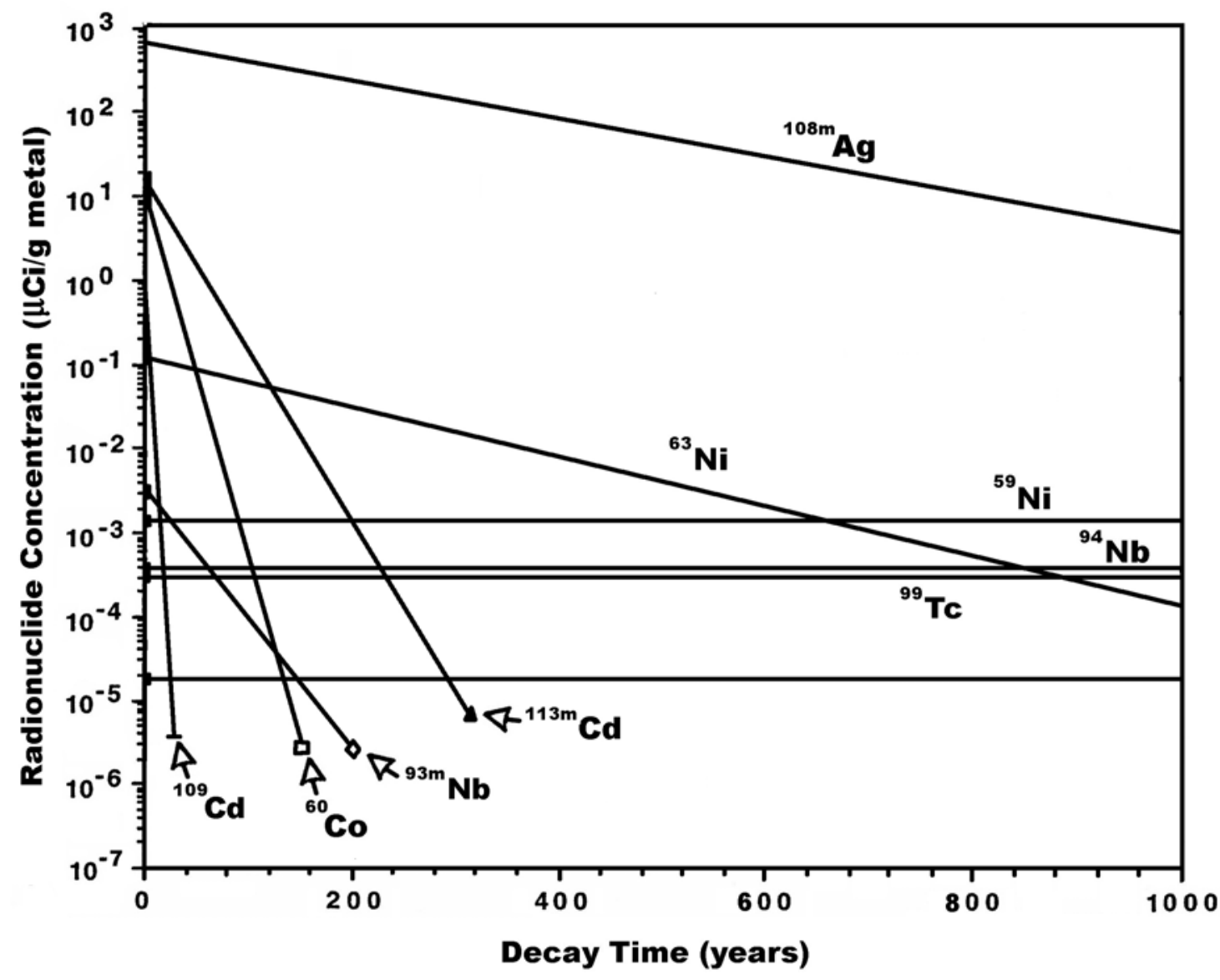

Figure 1.3. Change in Radionuclide Concentration with Time in a PWR Control Rod Containing Ag-Cd-In Alloy

The neutron activation product radionuclides ${ }^{59,63} \mathrm{Ni},{ }^{94} \mathrm{Nb}$, and ${ }^{14} \mathrm{C}$ are also present in these types of low-level waste materials in significant quantities, which is also shown in Figure 1.1 through Figure 1.3. However, very little has been published concerning the environment and biological uptake behavior of ${ }^{59,63} \mathrm{Ni}$ and ${ }^{94} \mathrm{Nb}$, and therefore they were included in this literature review and assessment.

\subsection{Section 1 References}

Leigh CD, BM Thompson, JE Campbell, DE Longsine, RA Kennedy, and BA Napier. 1992. User's Guide for GENII-S: A Code for Statistical and Deterministic Simulations of Radiation Doses to Humans from Radionuclides in the Environment. SAND91-0561A, Sandia National Laboratories, Albuquerque, NM.

McFadden K, DA Brosseau, WE Beyeler, and CD Updegraff. 2001. Residual Radioactive Contamination from Decommissioning, User's Manual DandD Version 2.1. NUREG/CR-5512, Vol. 2, U.S. Nuclear Regulatory Commission, Washington, D.C. 
Napier BA, DL Strenge, JV Ramsdell, Jr, PW Eslinger, and C Fosmire. 2003. GENII Version 2: Software Design Document, Pacific Northwest National Laboratory, Richland, WA. Available at http://www.epa.gov/rpdweb00/neshaps/models.htm

Yu C, AJ Zielen, JJ Cheng, DJ LePoire, E Gnanapragasam, S Kamboj, J Arnish, A Wallo III, WA Williams, and H Peterson. 2002. User's Manual for RESRAD Version 6. ANL/EAD-4, Argonne National Laboratory, Argonne, IL. 


\subsection{Speciation and Geochemistry of Radionuclides in Soil-Water Systems}

\subsection{Background}

The concentrations, mobility, and bioavailability of radionuclides in surface and subsurface geologic systems ${ }^{(a)}$ are controlled by numerous hydrologic and geochemical processes. These primarily include the amount and nature of radionuclides present at the source; the rate of their release from the source; hydrologic factors, such as dispersion, advection, and dilution; and geochemical processes, such as aqueous complexation, oxidation/reduction (redox), adsorption/desorption and ion exchange, precipitation/dissolution, diffusion, colloid-facilitated transport, and anion exclusion. Additionally, in the uppermost layer of surface soil, ${ }^{(b)}$ the mobility of radionuclides can also be increased by biological activity and by the drying and subsequent cracking of soils. Colloid-facilitated transport and anion exclusion have received considerable attention recently in that they can enhance the transport of certain radionuclides. However, these processes are hard to quantify, and the extent to which they occur is difficult to determine. The geochemical processes listed above are discussed in detail in sources such as Baes and Mesmer (1976), Garrels and Christ (1965), Langmuir (1997), Lindsay (1979), Morel (1983), Nordstrom and Munoz (1985), Sposito (1989, 1994), Stumm and Morgan (1981), Yariv and Cross (1979), and others, and the references cited therein. Table 2.1, taken from the U.S. Environmental Protection Agency (EPA 1999a), summarizes the mechanism, anticipated effect on radionuclide mobility, and key environmental factors associated with each of these geochemical processes. The reader is cautioned that the importance of colloid-facilitated migration, especially in aquifer systems that do not involve fracture flow of groundwater, is still a subject of debate.

Some radionuclides, such as technetium, uranium, and plutonium, may be present in more than one oxidation state in the environment. The adsorption and precipitation behavior of different oxidation states of a particular radionuclide are usually very different. For example, in environmental systems, the most stable oxidation states of technetium are +7 and +4 under oxidizing and reducing geochemical conditions, respectively. The chemical behavior of technetium in these two oxidation states differs drastically. Dissolved Tc(VII) exists as pertechnetate anion, $\mathrm{TcO}_{4}{ }^{-}$, over the complete $\mathrm{pH}$ range of natural waters under oxic conditions. Because the pertechnetate anion is highly soluble and is not strongly sorbed, it is highly mobile in most oxidizing systems. Under reducing conditions, however, Tc(IV) exists as hydrolyzed cations and is relatively immobile in the absence of strongly complexing ligands. Technetium(IV) is highly sorbed and forms the sparingly soluble $\mathrm{TcO}_{2} \cong \mathrm{nH}_{2} \mathrm{O}$ solid.

(a) Surface and subsurface geologic systems include soils, sediments, surface waters, soil pore waters, groundwaters, and geological rock formations.

(b) The terms "soil" and "sediment" have particular meanings, depending on one's technical discipline. For example, "soil" is often limited to referring to the top layer of the earth's surface, suitable for plant life. The term "sediment" is usually reserved for transported and deposited particles derived from soil, rocks, or biological material. In this report, the term "soil" is used to as a general term to refer to all unconsolidated geologic materials. 
Table 2.1. Summary of Chemical Processes Affecting the Mobility of Radionuclides

\begin{tabular}{|c|c|c|c|}
\hline $\begin{array}{l}\text { Geochemical } \\
\text { Process }\end{array}$ & Mechanism & $\begin{array}{c}\text { Affect on } \\
\text { Radionuclide Mobility }\end{array}$ & Important Factors \\
\hline $\begin{array}{l}\text { Aqueous } \\
\text { complexation }\end{array}$ & $\begin{array}{l}\text { Reaction where an } \\
\text { aqueous molecular unit } \\
\text { (ion) acts as a central } \\
\text { group to attract and } \\
\text { form a close } \\
\text { association with other } \\
\text { atoms or molecules }\end{array}$ & $\begin{array}{l}\text { May enhance mobility } \\
\text { or retardation, } \\
\text { depending on } \\
\text { radionuclide and } \\
\text { geochemical conditions }\end{array}$ & $\begin{array}{l}\text { - Function of } \mathrm{pH} \text { and redox conditions } \\
\text { - Complexation may lower the } \\
\text { potential for adsorption and/or } \\
\text { increase solubility, both of which can } \\
\text { enhance the potential for mobility } \\
\text { - Complexes may more readily bond to } \\
\text { soils and thus retard migration } \\
\text { - Organic ligands from humic } \\
\text { materials can be present in } \\
\text { significant concentrations and } \\
\text { dominate radionuclide complexation } \\
\text { in some systems }\end{array}$ \\
\hline $\begin{array}{l}\text { Oxidation/ } \\
\text { Reduction (redox) } \\
\text { reactions }\end{array}$ & $\begin{array}{l}\text { Reaction where } \\
\text { electrons are } \\
\text { transferred completely } \\
\text { from one species to } \\
\text { another }\end{array}$ & $\begin{array}{l}\text { May enhance mobility } \\
\text { or retardation, } \\
\text { depending on } \\
\text { radionuclide and } \\
\text { geochemical conditions }\end{array}$ & $\begin{array}{l}\text { - Change in redox status changes } \\
\text { aqueous speciation, which may } \\
\text { increase or decrease adsorption and } \\
\text { solubility } \\
\text { - If the redox status is sufficiently low } \\
\text { to induce the precipitation of sulfide } \\
\text { minerals, reprecipitation of some } \\
\text { radionuclides may be expected } \\
\text { - The more difficult to predict mobility } \\
\text { of redox-sensitive species because } \\
\text { many redox reactions are kinetically } \\
\text { slow in natural waters, and several } \\
\text { elements may never reach } \\
\text { equilibrium between their various } \\
\text { valence states }\end{array}$ \\
\hline $\begin{array}{l}\text { Adsorption/ } \\
\text { desorption and ion } \\
\text { exchange }\end{array}$ & $\begin{array}{l}\text { Special case of a } \\
\text { complexation reaction } \\
\text { where there is a net } \\
\text { accumulation of a } \\
\text { radionuclide at the } \\
\text { interface between a } \\
\text { solid phase and an } \\
\text { aqueous solution } \\
\text { phase; does not include } \\
\text { the development of a } \\
\text { three-dimensional } \\
\text { molecular structure }\end{array}$ & Enhances retardation & $\begin{array}{l}\text { - Occurs primarily in response to } \\
\text { electrostatic attraction } \\
\text { - Very dependent on pH and } \\
\text { mineralogy } \\
\text { - Anion adsorption is greatest at low } \\
\text { pH and decreases with increasing pH } \\
\text { - Cation adsorption is greatest at high } \\
\text { pH and decreases with deceasing pH } \\
\text { - Some radionuclides may be present } \\
\text { as cations or anions , dependingon } \\
\text { pH } \\
\text { - Totally-to-partially reversible; } \\
\text { decline in dissolved radionuclide } \\
\text { concentration may result in } \\
\text { desorption and release of adsorbed } \\
\text { radionuclide to water } \\
\text { - Likely key process controlling } \\
\text { radionuclide mobility in areas where } \\
\text { chemical equilibrium exists }\end{array}$ \\
\hline
\end{tabular}


Table 2.1. (cont'd)

\begin{tabular}{|c|c|c|c|}
\hline $\begin{array}{l}\text { Geochemical } \\
\text { Process }\end{array}$ & Mechanism & $\begin{array}{c}\text { Affect on } \\
\text { Radionuclide Mobility }\end{array}$ & Important Factors \\
\hline $\begin{array}{l}\text { Precipitation/ } \\
\text { dissolution }\end{array}$ & $\begin{array}{l}\text { Special case of a } \\
\text { complexation reaction } \\
\text { in which the complex } \\
\text { formed by two or more } \\
\text { aqueous species is a } \\
\text { solid with three- } \\
\text { dimensional molecular } \\
\text { structure }\end{array}$ & Enhances retardation & $\begin{array}{l}\text { - Very dependent on } \mathrm{pH} \text { and redox } \\
\text { conditions } \\
\text { - Totally-to-partially reversible; decline in } \\
\text { dissolved radionuclide concentration } \\
\text { may result in dissolution of precipitated } \\
\text { radionuclide to groundwater } \\
\text { - Likely process where chemical } \\
\text { nonequilibium exists, an area where } \\
\text { high radionuclide concentrations exist, } \\
\text { or where steep pH and/or redox } \\
\text { gradients exist }\end{array}$ \\
\hline Diffusion & $\begin{array}{l}\text { Molecular process of } \\
\text { transport of matter in } \\
\text { the absence of bulk } \\
\text { flow }\end{array}$ & Enhances mobility & $\begin{array}{l}\text { Flux of matter due to diffusion is } \\
\text { proportional to concentration gradient }\end{array}$ \\
\hline $\begin{array}{l}\text { Colloid- } \\
\text { facilitated } \\
\text { transport }\end{array}$ & $\begin{array}{l}\text { Radionuclides } \\
\text { associated with } \\
\text { suspended fine-grained } \\
\text { material (smaller than } \\
\text { clay size) that may be } \\
\text { transported with } \\
\text { flowing soil pore water } \\
\text { and groundwater }\end{array}$ & Enhances mobility & $\begin{array}{l}\text { Little information on occurrence, } \\
\text { mineralogical and physicochemical } \\
\text { properties, or conditions conducive to } \\
\text { the generation of mobile colloids } \\
\text { - May originate from the dispersion of } \\
\text { soils, decementation of secondary } \\
\text { mineral phases, and/or the precipitation } \\
\text { of groundwater constituents } \\
\text { - Difficult-to-collect colloids from } \\
\text { subsurface in a manner that minimizes } \\
\text { or eliminates sampling artifacts } \\
\text { Difficult-to-unambiguously delineate } \\
\text { between the radionuclides in the } \\
\text { mobile-aqueous and mobile-solid } \\
\text { phases }\end{array}$ \\
\hline $\begin{array}{l}\text { Anion } \\
\text { exclusion }\end{array}$ & $\begin{array}{l}\text { Occurs when the } \\
\text { diffuse double layer, an } \\
\text { extension of a particle's } \\
\text { negative surface charge } \\
\text { into the surrounding } \\
\text { solution, repulses } \\
\text { anions }\end{array}$ & Enhances mobility & $\begin{array}{l}\text { - By excluding anions from the diffuse } \\
\text { double layer, where water is relatively } \\
\text { immobile, anions restricted to the faster } \\
\text { moving pore water, resulting in an } \\
\text { average rate of anion transport greater } \\
\text { than the average pore-water velocity } \\
\text { defined by Darcy's Law } \\
\text { - More pronounced with higher CEC, i.e., } \\
\text { negative charge, of the soil or rock. }\end{array}$ \\
\hline
\end{tabular}


Adsorption/desorption (including ion exchange) and precipitation/dissolution are considered the most important processes affecting radionuclide interactions with soils. Precipitation/dissolution is more likely to be an important process where elevated concentrations of dissolved radionuclides exist, such as in the near-field environment of radioactive waste disposal facilities or the spill sites of radionuclide-containing wastes or where steep $\mathrm{pH}$ or redox gradients exist. Adsorption/desorption will likely be the key process controlling radionuclide retardation in areas where trace concentrations of dissolved radionuclides exist, such as those associated with farfield environments of disposal facilities or spill sites or in areas of where soils are to be irrigated using radionuclide-contaminated water.

Adsorption occurs primarily in response to electrostatic attraction. The degree of adsorption of ions is strongly governed by the $\mathrm{pH}$ of the solution because the magnitude and polarity of the net surface charge of a solid changes with $\mathrm{pH}$. Mineral surfaces become increasingly more negatively charged as $\mathrm{pH}$ increases. The $\mathrm{pH}$ at which the net charge of solid surface changes from positive to negative is called the point-of-zero charge (PZC), or zero point of charge (ZPC) (Stumm and Morgan 1981; Langmuir 1997). At $\mathrm{pH}$ values greater than the $\mathrm{pH}_{\mathrm{PZC}}$, deprotonation of surface hydroxyl groups results in a net negative charge. At $\mathrm{pH}$ values less than the $\mathrm{pH}_{\mathrm{PZC}}$, the surface becomes protonated, which results in a net positive surface charge. Therefore, adsorption of radionuclides present as anions is expected to be greatest at low $\mathrm{pH}$ and decreases with increasing $\mathrm{pH}$. the adsorption of cations, on the other hand, is greatest at high $\mathrm{pH}$ and decreases with decreasing $\mathrm{pH}$.

Throughout this section, "sorption" will be used as a generic term devoid of mechanism and used to describe the partitioning of dissolved aqueous-phase constituents to a solid phase. When a radionuclide is associated with a geologic material, however, it is usually not known if the radionuclide is adsorbed onto the surface of the solid, absorbed into the structure of the solid, precipitated as a three-dimensional molecular structure on the surface of the solid, or partitioned into the organic matter (Sposito 1989). The term "sorption" encompasses all of the above processes.

The sorption of radionuclides on soils is frequently quantified by the partition (or distribution) coefficient $\left(\mathrm{K}_{\mathrm{d}}\right)$. The $\mathrm{K}_{\mathrm{d}}$ parameter is a factor related to the partitioning of a radionuclide between the solid and aqueous phases and is defined as the ratio of the quantity of the adsorbate adsorbed per mass of solid to the amount of the adsorbate remaining in solution at equilibrium. Radionuclides that adsorb very strongly to soil have large $\mathrm{K}_{\mathrm{d}}$ values (typically greater than $100 \mathrm{~mL} / \mathrm{g}$ ) compared to those values for radionuclides that are not significantly retarded by adsorption. Radionuclides that do not adsorb to soil and migrate essentially at the same rate as the waterflow have $\mathrm{K}_{\mathrm{d}}$ values near $0 \mathrm{~mL} / \mathrm{g}$. The $\mathrm{K}_{\mathrm{d}}$ model is the simplest yet least robust sorption model available. However, the $\mathrm{K}_{\mathrm{d}}$ metric is the most common measure used in hydrologic transport and biosphere codes to describe the extent to which contaminants are sorbed to soils. The primary advantage of the $\mathrm{K}_{\mathrm{d}}$ model is that it is easily inserted into computer codes to quantify the reduction in the extent of transport of a radionuclide relative to groundwater. The $\mathrm{K}_{\mathrm{d}}$ is an empirical unit of measurement that attempts to account for various chemical and physical retardation mechanisms that are influenced by a myriad of variables. As such, the $\mathrm{K}_{\mathrm{d}}$ model is often the subject of criticism. The technical issues, complexities, and shortcomings of 
the $\mathrm{K}_{\mathrm{d}}$ approach to describing radionuclide sorption to soils are discussed in detail in EPA (1999a) and the references cited therein.

\subsection{Eh-pH Species Predominance Diagrams}

Computer modeling methods were used to calculate from equilibrium thermodynamic principals, the distributions of dominant aqueous species, and potential solubility controls for the environmentally important oxidation states of each of the selected radionuclides. The results of these speciation and solubility calculations for each radionuclide were graphically presented as a series of Eh-pH (or Pourbaix) diagrams. The theory behind the calculation of Eh-pH diagrams is discussed by Garrels and Christ (1965), Langmuir(1997), Nordstrom and Munoz (1985), and others.

The Eh-pH diagrams were calculated for this report using the The Geochemist's Workbench ${ }^{\circledR}$ (Version 4.0) software package and the expanded thermodynamic database file "thermo.com.V8.R6+.dat" provided with the software package. The Lawrence Livermore National Laboratory (LLNL) developed this database file originally for use with the EQ3/6 geochemical model. The Eh-pH diagrams presented below are meant for demonstration purposes only. It was beyond the scope and available resources for this project to evaluate the adequacy of the species and constants in the thermodynamic database relative to what is available in the most current literature. It should be noted that this database file does include the thermodynamic values for the uranium and americium species given, respectively, in the extensive reviews by Grenthe et al. (1992) and Silva et al. (1995). The database file, however, does predate the publication of the extensive reviews of technetium species and associated thermodynamic values by Rard et al. (1999) and of neptunium and plutonium species and associated thermodynamic values by Lemire et al. (2001).

Unless otherwise noted, the Eh-pH diagrams were calculated at 25EC for an aqueous solution having the hypothetical "average value" composition listed in Table 2.2 and a radionuclide concentration of $1 \times 10^{-8} \mathrm{~mol} / \mathrm{L}$. This water analysis was provided by the NRC Technical Monitor for geochemical modeling calculations completed on an earlier NRC project, and represented at that time, the composition of an aqueous solution being considered by NRC for a low-level radioactive waste (LLW) performance assessment (PA) test case. The radionuclide concentration of $1 \times 10^{-8} \mathrm{~mol} / \mathrm{L}$ was arbitrarily selected to help demonstrate the importance of aqueous complexation, redox, and possible solubility reactions for each radionuclide. Although radionuclide concentrations in the far-field environments, such as deep groundwater and irrigated water systems, will likely be lower than $1 \times 10^{-8} \mathrm{~mol} / \mathrm{L}$, the dominant aqueous species that are calculated at lower concentrations of each radionuclide will not differ significantly from those plotted in the Eh-pH diagrams in following section. Each diagram contains two dashed black lines at (Eh $1.2 \mathrm{~V}-\mathrm{pH} 0$ to Eh $0.4 \mathrm{~V}-\mathrm{pH} 14)$ and (Eh $0.0 \mathrm{~V}-\mathrm{pH} 0$ to Eh $-0.8 \mathrm{~V}-\mathrm{pH}$ 14) that represent the Eh-pH boundaries at 1 atm pressure for the breakdown of water to its gaseous components. The redox conditions for essentially all environmental systems occur in the region within these water-stability limits. At Eh-pH values above the upper black dashed line, water breaks down to oxygen gas. At Eh-pH values below the lower black dashed line, water breaks down to hydrogen gas. 
Table 2.2. Composition of Groundwater Used for Aqueous Speciation Calculations

\begin{tabular}{|c|c|c|}
\hline Variable & Average Value & Range \\
\hline $\mathrm{pH}$ & 5.8 & $4.5-7.3$ \\
\hline $\mathrm{Eh}(\mathrm{mV})$ & 500 & $350-700$ \\
\hline Conductivity $(\mu \mathrm{mho} / \mathrm{cm})$ & 50 & $10-250$ \\
\hline Dissolved oxygen (ppm) & 6 & $5-10$ \\
\hline Total dissolved solids (ppm) & 13 & $10-20$ \\
\hline Dissolved organic carbon (ppm) & 6 & - (a) \\
\hline Alkalinity $\left(\mathrm{CaCO}_{3}\right)(\mathrm{ppm})$ & 15 & $1-100$ \\
\hline Cations & \multicolumn{2}{|c|}{$\longrightarrow$ ppm } \\
\hline $\mathrm{Na}$ & 6 & $<1-17$ \\
\hline $\mathrm{K}$ & 2 & $0.2-10$ \\
\hline $\mathrm{Ca}$ & 3 & $<0.1-40$ \\
\hline $\mathrm{Mg}$ & 0.4 & $<0.01-3$ \\
\hline $\mathrm{Fe}$ & 0.030 & $0.010-1.600$ \\
\hline $\mathrm{Mn}$ & 0.030 & $0.005-0.780$ \\
\hline $\mathrm{SiO}_{2}$ (silica) & 6 & $0.1-12$ \\
\hline $\mathrm{Ba}$ & 0.2 & $0-1$ \\
\hline $\mathrm{Sr}$ & 0.1 & $0-0.5$ \\
\hline Anions & \multicolumn{2}{|c|}{$\longrightarrow$ ppm } \\
\hline $\mathrm{F}$ & 0.1 & $0-0.4$ \\
\hline $\mathrm{Cl}$ & 4 & $0.5-16$ \\
\hline $\mathrm{NO}_{3}+\mathrm{NO}_{2}($ as $\mathrm{N})$ & 0.2 & $0.02-4$ \\
\hline $\mathrm{SO}_{4}$ & 2 & $0.2-20$ \\
\hline $\mathrm{PO}_{4}$ & - $^{\text {(b) }}$ & $0.03-2.2$ \\
\hline
\end{tabular}

Obviously, there are significant differences between surface waters and groundwaters, and considerable variability in the concentrations of various constituents in surface and groundwaters. The Eh-pH calculations plotted below simply demonstrate what species might exist for a given radionuclide in any water containing the specified concentrations of each inorganic ligand in Table 2.2. If the concentration of a complexing ligand, such as phosphate, is less for a site-specific groundwater compared to that used for our calculations, then aqueous complexes containing that radionuclide and ligand may be less important for that water. Also, it is important to note that the water composition in Table 2.2 has a low ionic strength and contains no natural, e.g., humic or fulvic acids ${ }^{(a)}$, or anthropogenic, e.g., ethylenediaminetetraacetic acid

(a) "Humic and fulvic acids are breakdown products of cellulose from vascular plants. Humic acids are defined as the alkaline-soluble portion of the organic material (humus), which precipitates from solution at low $\mathrm{pH}$, and are generally of high molecular weight. Fulvic acids are the alkaline-soluble portion that remains in solution at low $\mathrm{pH}$ and is of lower molecular weight" (Gascoyne 1982). 
(EDTA), organic ligands. Some radionuclides can form strong complexes with natural or anthropogenic organic ligands, which can have important effects on their mobility and bioavailability in soils.

\subsection{Geochemical Processes Affecting the Mobility and Bioavailability of Selected Radionuclides}

The purpose of the following sections in this chapter is to provide a thumbnail sketch of the key geochemical processes affecting the mobility and bioavailability of each of the selected radionuclides in soils. Because aqueous complexation, redox, and sorption processes do not vary from isotope to isotope of any particular element, the following discussions will be presented for convenience in terms of the element and its various oxidation states and not in terms of any particular isotope.

\subsubsection{Cesium-137 $\left({ }^{137} \mathrm{Cs}\right)$}

The environmental behavior of cesium has been reviewed by others, such as EPA (1999b), Lieser and Steinkopff (1989a), Onishi et al. (1981), and Ames and Rai (1978). Cesium exists in environment systems in the +1 oxidation state. The speciation of cesium in environmental systems is relatively simple compared to the other contaminants considered in this summary. Cesium will exist predominately as the uncomplexed $\mathrm{Cs}^{+}$ion, as shown in the Eh-pH diagram in Figure 2.1, across the full $\mathrm{pH}$ range of aqueous systems. Cesium does not form any important aqueous complexes with ligands and organic matter found in natural systems. Cesiumcontaining solids are highly soluble in aqueous systems. Therefore, the precipitation and coprecipitation of cesium-containing solids are not important processes in controlling the concentration of dissolved cesium in environmental systems.

Cesium sorbs rather strongly to most minerals, i.e., large $K_{d}$ values. The sorption of cesium is reviewed in detail in EPA (1999b). Cesium sorption occurs primarily by ion exchange in most soil systems except when mica-like minerals are present. On certain mica-like clay minerals, such as illite $\left\{\left(\mathrm{K}, \mathrm{H}_{3} \mathrm{O}\right)(\mathrm{Al}, \mathrm{Mg}, \mathrm{Fe})_{2}(\mathrm{Si}, \mathrm{Al})_{4} \mathrm{O}_{10}\left[(\mathrm{OH})_{2}, \mathrm{H}_{2} \mathrm{O}\right]\right\}$ and vermiculite $\left[\left(\mathrm{Mg}, \mathrm{Fe}^{\mathrm{II}}, \mathrm{Al}\right)_{3}(\mathrm{Si}, \mathrm{Al})_{4} \mathrm{O}_{10}(\mathrm{OH})_{2} \cdot 4 \mathrm{H}_{2} \mathrm{O}\right]$, cesium sorption results in the selective fixation of cesium between structural layers of these minerals. Some researchers have considered the exchange of trace cesium on these mica-like clays to be nearly irreversible (see Douglas 1989 and references therein). The extent to which cesium sorbs by this process will depend on the concentration of mica-like clays in the soil, and the concentration of major cations, such as $\mathrm{K}^{+}$(EPA 1999b). The $\mathrm{K}^{+}$can effectively compete with $\mathrm{Cs}^{+}$for ion exchange sites because its hydrated ionic radii are similar and smaller than those for the other alkali and alkaline earth ions. Cesium may also adsorb to iron oxides by complexation of cesium to surface mineral sites whose abundance is $\mathrm{pH}$ dependent (Schwertmann and Taylor 1989). The sorption of cesium to humic substances is generally quite weak (Bovard et al. 1968). Because cesium readily sorbs to minerals, there is a potential for colloid-facilitated transport of cesium that is sorbed on colloidal-size particles of soil minerals. 


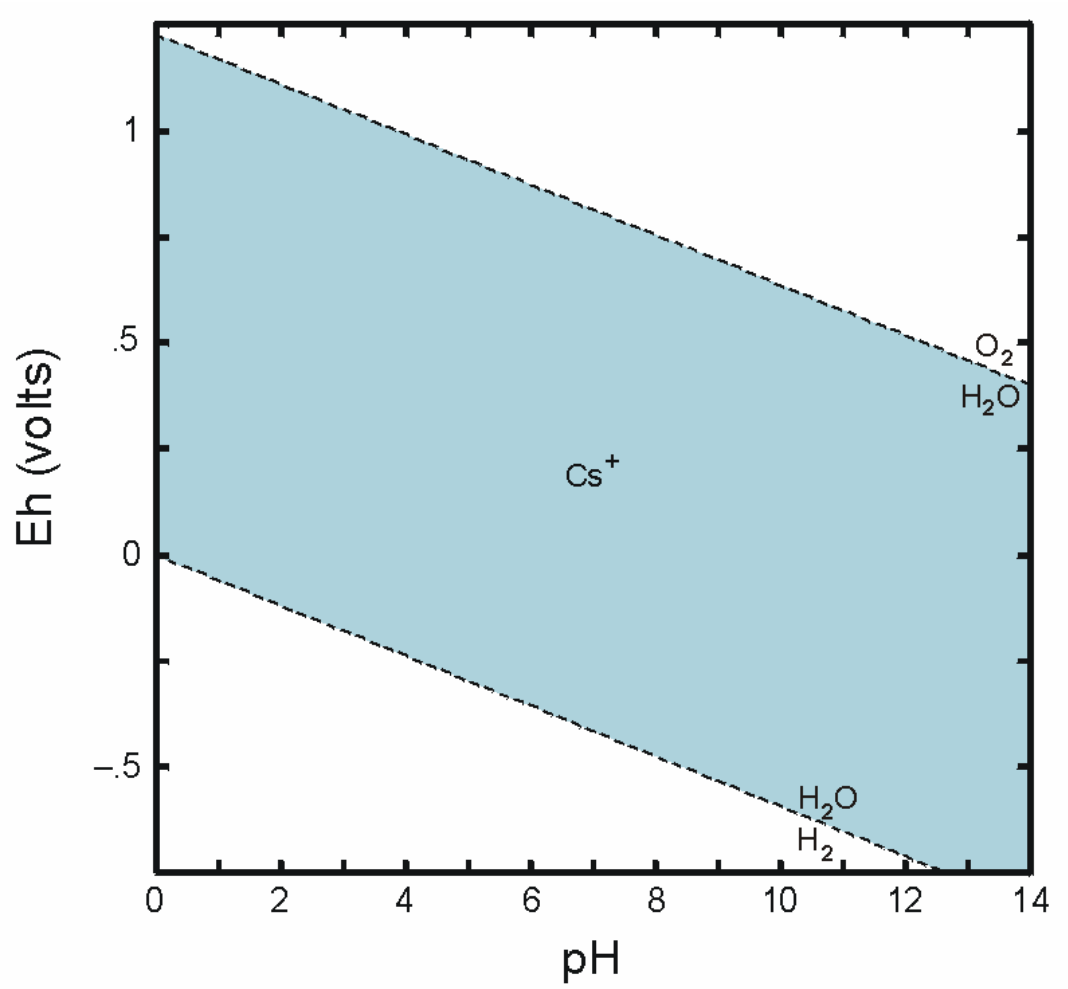

Figure 2.1. Eh-pH Diagram Showing Dominance of Uncomplexed $\mathrm{Cs}^{+}$Aqueous Species (diagram was calculated at a total concentration of $1 \times 10^{-8} \mathrm{~mol} / \mathrm{L}$ dissolved cesium at $25^{\circ} \mathrm{C}$ )

\subsubsection{Strontium-90 $\left({ }^{90} \mathrm{Sr}\right)$}

The geochemical behavior of strontium in nature has been reviewed by EPA (1999b), Onishi et al. (1981), Ames and Rai (1978), and others. Strontium is an alkaline-earth element and exists in environmental systems only in the +2 oxidation state. The speciation of strontium in aqueous systems will not be significantly affected by complexation with dissolved inorganic, e.g., carbonate, sulfate, chloride, and nitrate, and organic ligands (EPA 1999b and references therein). The Eh-pH diagram in Figure 2.2 shows the dominant strontium aqueous species calculated at $25^{\circ} \mathrm{C}$ using a total concentration of $1 \times 10^{-8} \mathrm{~mol} / \mathrm{L}$ dissolved strontium and the ligand concentrations listed in Table 2.2. These calculations indicate that dissolved strontium will be present predominantly as the uncomplexed $\mathrm{Sr}^{2+}$ ion throughout the entire $\mathrm{pH}$ range up to approximately a $\mathrm{pH}$ of 11 . At $\mathrm{pH}$ values greater than 11 , the neutral carbonate complex $\mathrm{SrCO}_{3}{ }^{\circ}(\mathrm{aq})$ is predicted to be the dominant aqueous complex of strontium at these geochemical conditions.

In alkaline, high $\mathrm{pH}$ soils, the precipitation of strontianite $\left(\mathrm{SrCO}_{3}\right)$ or coprecipitation in calcite may be important mechanisms for controlling the maximum concentrations of dissolved strontium (Lefevre et al. 1993). As an alkaline-earth element, strontium can form similar solid phases as those with calcium. In certain soil systems, celestite $\left(\mathrm{SrSO}_{4}\right)$ and strontianite are potentially two important solubility controls for strontium, but most strontium minerals are highly soluble. These two strontium minerals are analogous to anhydrite $\left(\mathrm{CaSO}_{4}\right)$ and calcite 
$\left(\mathrm{CaCO}_{3}\right)$ for calcium. Celestite may precipitate in acidic soil environments at elevated concentrations of total dissolved strontium and sulfate, e.g., greater than $10^{-4}-\mathrm{mol} / \mathrm{L}$ total strontium. Strontianite, on the other hand, is only stable in highly alkaline soils. Based on the ligand concentrations in Table 2.2, an aqueous solution containing a total concentration of dissolved strontium of $10^{-7.7} \mathrm{~mol} / \mathrm{L}$ calculates to be oversaturated with respect to the solubility of strontianite at $\mathrm{pH}$ values greater than 11 (Figure 2.3). Under these geochemical conditions, strontianite may potentially precipitate in soils having these elevated $\mathrm{pH}$ conditions and control the maximum concentration of total dissolved strontium. At higher strontium concentrations, the Eh-pH region of strontianite oversaturation would extend to lower, near-neutral $\mathrm{pH}$ values. At strontium concentrations less than $10^{-7.7} \mathrm{~mol} / \mathrm{L}$, strontianite calculates to be undersaturated for these geochemical conditions.

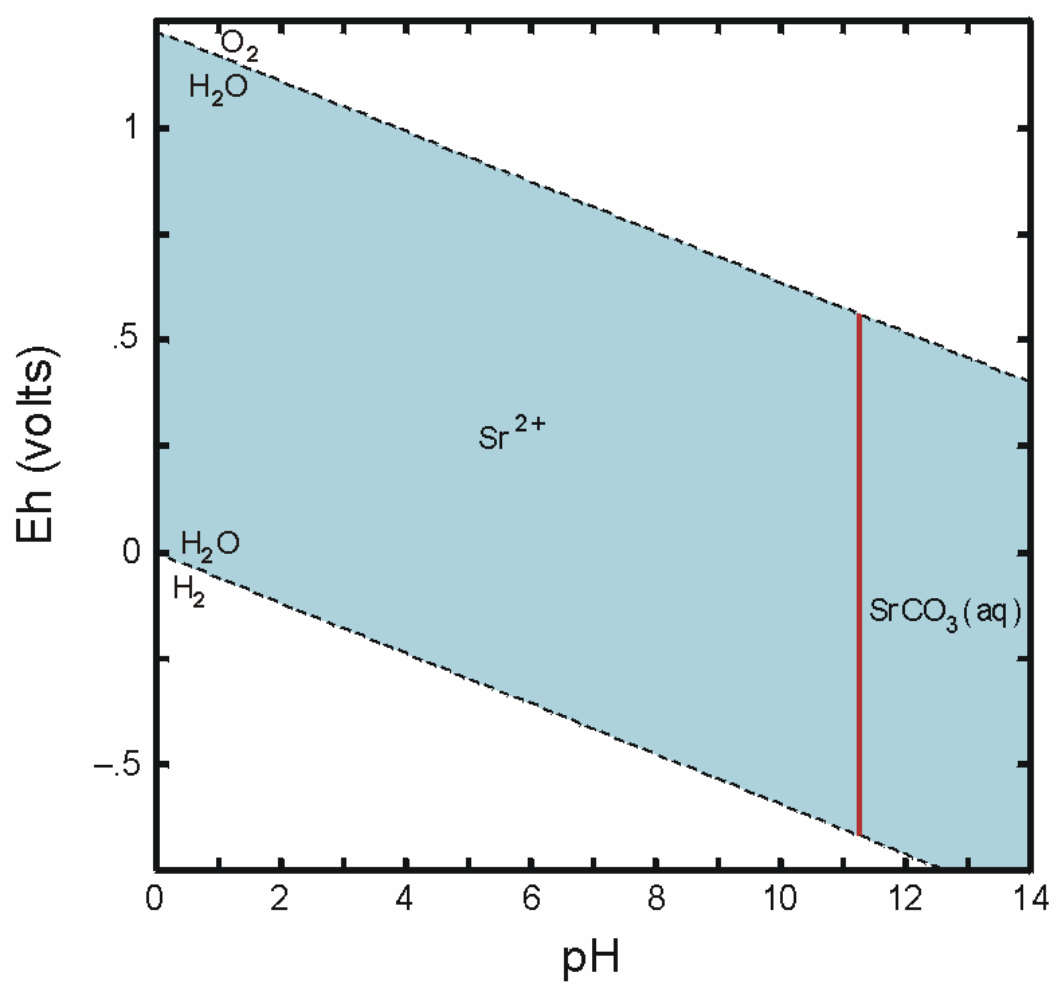

Figure 2.2. Eh-pH Diagram Showing Dominant Aqueous Species of Strontium (diagram was calculated at a total concentration of $1 \times 10^{-8} \mathrm{~mol} / \mathrm{L}$ dissolved strontium at $25^{\circ} \mathrm{C}$ )

However, strontium does not commonly precipitate as a pure, end-member mineral, such as strontianite, in soils, because the total concentrations of dissolved strontium in most environmental systems are typically less than the solubility limits of strontium-containing minerals and much lower than the concentrations of dissolved calcium. Because the ionic radii for $\mathrm{Sr}^{2+}(1.12 \AA)$ and $\mathrm{Ca}^{2+}(0.99 \AA)$ are similar, strontium can substitute for calcium in the structure of minerals to coprecipitate, i.e., forms a limited solid solution, as a strontium-containing calcite $\left(\mathrm{Ca}_{1-\mathrm{x}} \mathrm{Sr}_{\mathrm{x}} \mathrm{CO}_{3}\right)$ (Veizer 1983; Faure and Powell 1972). 
The adsorption of strontium has been studied and reviewed extensively (see the reviews in Ames and Rai 1978; Onishi et al. 1981; Strenge and Peterson 1989; EPA 1999b, and the studies cited therein). In most soil systems, the adsorption of strontium is controlled primarily by cation exchange. The most important ancillary parameters affecting the adsorption and $\mathrm{K}_{\mathrm{d}}$ values for strontium are the $\mathrm{CEC}$ of soil, $\mathrm{pH}$, and concentrations of calcium and stable strontium naturally present in soil. Strontium $\mathrm{K}_{\mathrm{d}}$ values vary over a wide range, depending on the values of these parameters, and typically increase with increasing CEC and $\mathrm{pH}$ values. Strontium $\mathrm{K}_{\mathrm{d}}$ values of less than $1 \mathrm{~mL} / \mathrm{g}$ to more than 30,000 mL/g have been reported (EPA 1999b; Sheppard and Thibault 1990). The correlation between strontium $\mathrm{K}_{\mathrm{d}}$ values and $\mathrm{pH}$ is likely the result of $\mathrm{H}^{+}$ ions competing with $\mathrm{Sr}^{2+}$ for exchange sites.

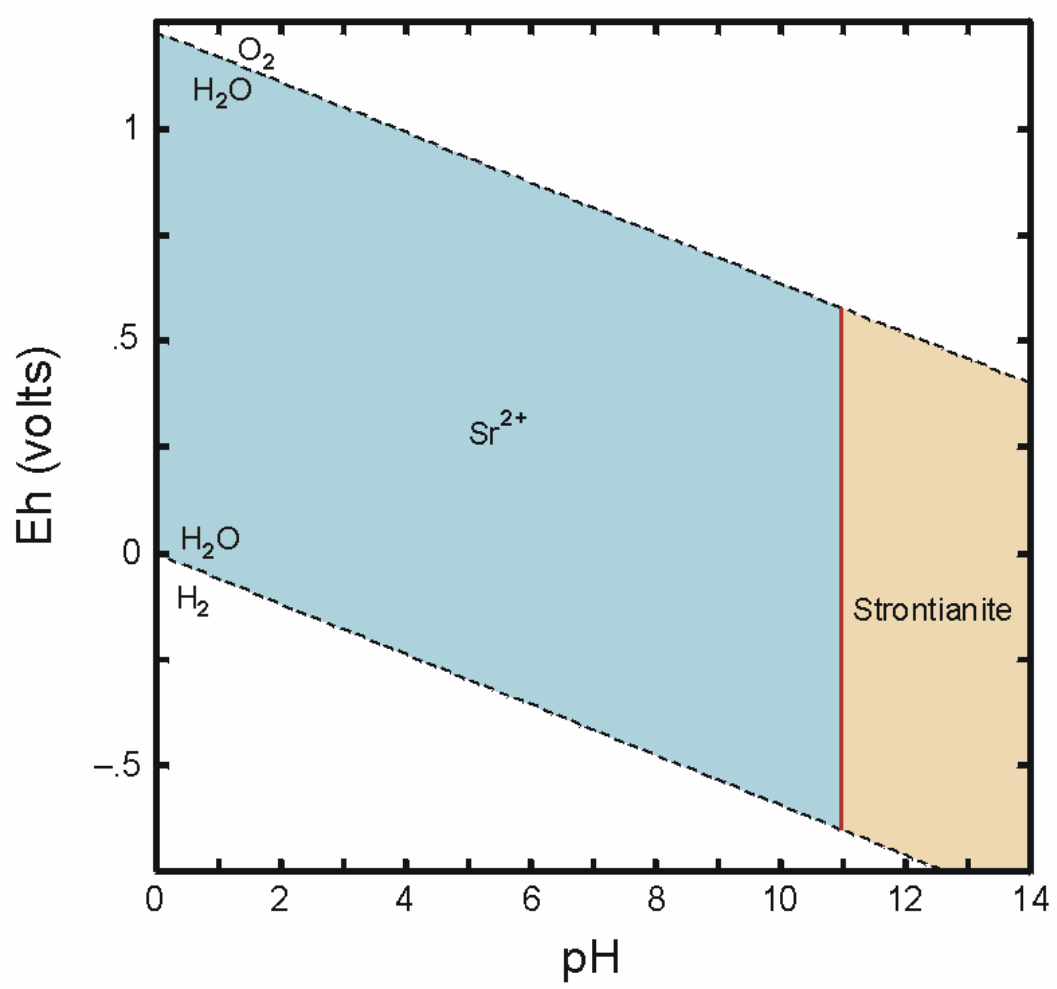

Figure 2.3. Diagram Showing Eh-pH Region (tan colored) that Calculates to be Oversaturated with Respect to the Solubility of Strontianite $\left(\mathrm{SrCO}_{3}\right)$ (diagram was calculated at a total concentration of $1 \times 10^{-7.7} \mathrm{~mol} / \mathrm{L}$ dissolved strontium at $25^{\circ} \mathrm{C}$ )

The adsorption of strontium has also been found to decrease with increasing ionic strength (Rhodes 1957; Routson et al. 1980) and increasing concentrations of competing cations, such as calcium and stable strontium (Kokotov and Popova 1962; Schulz 1965). Adsorption studies indicate that strontium will dominate most alkaline and alkaline earth elements in competition for exchange sites on an equivalence basis (see studies cited in EPA 1999b). Kokotov and Popova (1962) list the following ranking of the most common groundwater cations relative to their capability to compete with radioactive strontium for exchange sites:

$$
\text { Stable } \mathrm{Sr}^{2+}>\mathrm{Ca}^{2+}>\mathrm{Mg}^{2+}>\mathrm{K}^{+}>\mathrm{NH}_{4}{ }^{+}>\mathrm{Na}^{+}
$$


However, because calcium concentrations in environmental systems are commonly a couple orders of magnitude greater than stable strontium concentrations and many orders of magnitude greater than ${ }^{90} \mathrm{Sr}$ concentrations, the significantly greater mass of calcium increases the possibility that calcium will outcompete strontium, especially ${ }^{90} \mathrm{Sr}$, for exchange sites and decrease the adsorption of strontium in soils.

\subsubsection{Technetium-99 $\left({ }^{99} \mathrm{Tc}\right)$}

The behavior of technetium in environmental systems has been reviewed extensively by others. Reviews include EPA (2003), Lieser (1993), Gu and Schulz (1991), Sparks and Long (1987), Meyer et al. (1985), Beasley and Lorz (1984), Coughtrey et al. (1983), Onishi et al. (1981), Wildung et al. (1979), Ames and Rai (1978), and others. Hughes and Rossotti (1987) review in detail the solution chemistry of technetium. Technetium exists in oxidation states from +7 to -1 . In natural environments, the most stable oxidation states of technetium are +7 and +4 under oxidizing and reducing conditions, respectively. Other oxidation states are encountered chiefly in complex compounds (Mazzi 1989).

Technetium(VII) can be reduced to Tc(IV) by abiotic and biotic processes. This reduction results in a decrease in the dissolved concentrations of technetium due to the precipitation of the sparingly soluble, amorphous $\mathrm{TcO}_{2} \cdot 2 \mathrm{H}_{2} \mathrm{O}$. In reduced iron-sulfide systems, $\mathrm{Tc}$ (VII) can be reduced to Tc(IV) by coprecipitation with FeS solid (mackinawite) (Wharton et al. 2000). The reduction of Tc(VII) to Tc(IV) by surface-mediated processes has been the subject of extensive studies due to the importance of these reactions relative to the possible retardation of technetium in environmental systems and development of permeable barrier technologies, e.g., Wharton et al. 2000; Byegård et al. 1992; Eriksen and Cui 1991; Haines et al. 1987; Bondietti and Francis 1979.

Microbial reduction of $\mathrm{Tc}(\mathrm{VII})$ has also been suggested as a potential mechanism for retardation and removal of technetium from contaminated soils and waters, e.g., Lovley (1993, 1995). Certain dissimilatory metal-reducing bacteria and sulfate-reducing bacteria have been determined to be capable of coupling the oxidation of organic carbon or hydrogen to the reduction of Tc(VII) to Tc(IV) (Lloyd and Macaskie 1996; Lloyd et al. 1997, 1998, 1999, 2000b; Wildung et al. 2000; Fredrickson et al. 2000).

The environmental behavior of technetium under oxic conditions has been studied extensively. Figure 2.4 is an Eh-pH diagram that shows the dominant aqueous hydrolytic species of technetium in the absence of dissolved ligands other than hydroxide. The diagram was calculated at $25^{\circ} \mathrm{C}$ using a concentration of $1 \times 10^{-7.5} \mathrm{~mol} / \mathrm{L}$ total dissolved technetium. Dissolved technetium is present in oxic environmental systems as the aqueous $\mathrm{Tc}(\mathrm{VII})$ oxyanion species $\mathrm{TcO}_{4}{ }^{-}$over the complete $\mathrm{pH}$ range of natural waters. The $\mathrm{TcO}_{4}{ }^{-}$anion is essentially nonadsorptive, i.e., $\mathrm{K}_{\mathrm{d}}$ values are $\approx 0 \mathrm{~mL} / \mathrm{g}$, at near neutral and basic $\mathrm{pH}$ values and is also highly soluble. The concentration of Tc(VII) in soils and groundwater will therefore not be limited by adsorption or solubility processes and thus will be highly mobile in oxic environments. 


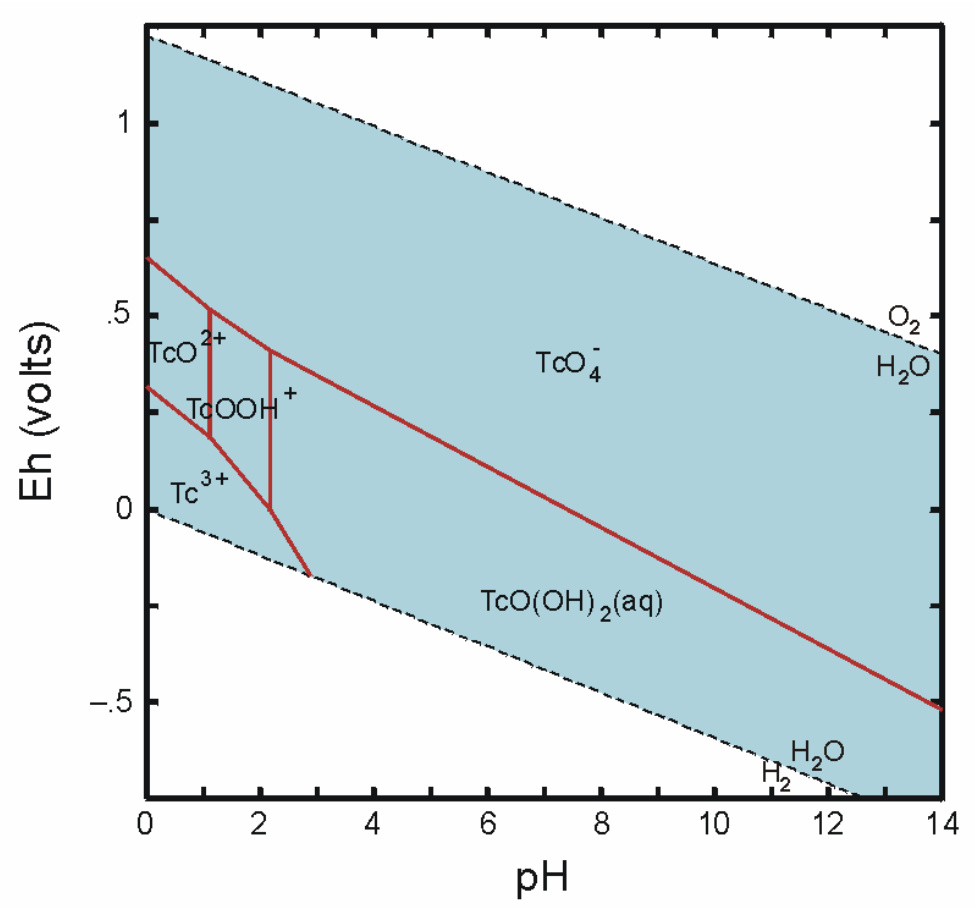

Figure 2.4. Eh-pH Diagram Showing Dominant Aqueous Species of Technetium (diagram was calculated at a total concentration of $1 \times 10^{-7.5} \mathrm{~mol} / \mathrm{L}$ dissolved technetium at $25^{\circ} \mathrm{C}$ )

Under reducing conditions, technetium aqueous speciation is dominated at $\mathrm{pH}$ values greater than 2 by the neutral $\mathrm{Tc}(\mathrm{IV})$ species $\mathrm{TcO}(\mathrm{OH})_{2}{ }^{\circ}$ (aq) in the absence of dissolved carbonate (Figure 2.4). In carbonate-containing waters, Tc(IV) carbonate complexes, such as $\mathrm{TcCO}_{3}(\mathrm{OH})_{2}{ }^{\circ}(\mathrm{aq})$ and $\mathrm{TcCO}_{3}(\mathrm{OH})_{3}{ }^{-}$, may become important aqueous complexes of technetium (Eriksen et al. 1992; Paquette and Lawrence 1985). Thermodynamic calculations suggest the possible formation of $\mathrm{Tc}^{3+}$ at $\mathrm{pH}$ values less than 2 under extremely reducing conditions. Technetium(IV) is sparingly soluble and highly sorbed and is therefore considered to be essentially immobile in reducing environments.

Rard et al. (1999) have published an extensive, detailed review of the chemical thermodynamics of americium aqueous species and solids. However, as previously noted, the thermodynamic database used to calculate the Eh-pH diagram predates the data tabulated in Rard et al. (1999). Although the thermodynamic stability of $\mathrm{TcO}_{4}{ }^{-}$is well established, thermodynamic data for other aqueous complexes and solids containing technetium in its various valence states are extremely limited (see Rard et al. 1999). The absence of such data precludes the use of thermodynamic calculations to evaluate the environmental behavior of reduced species of dissolved technetium with respect to $\mathrm{pH}$, Eh, and the presence of important dissolved complexing ligands such as dissolved phosphate, sulfate, chloride, and others. Studies of technetium under reducing conditions are limited compared to the number of technetium studies conducted under oxic conditions.

The reader should note that many species distribution calculations and Eh-pH diagrams presented in literature published before the critical review by Rard et al. (1999) included the 
aqueous neutral dimer species $\left[\mathrm{TcO}(\mathrm{OH})_{2}\right]_{2}{ }^{\mathrm{o}}(\mathrm{aq})$. For many calculations, $\left[\mathrm{TcO}(\mathrm{OH})_{2}\right]_{2}{ }^{\mathrm{o}}$ (aq) was predicted to be the dominant $\mathrm{Tc}(\mathrm{IV})$ species at neutral and basic $\mathrm{pH}$ values instead of the monomer $\mathrm{TcO}(\mathrm{OH})_{2}{ }^{\mathrm{o}}(\mathrm{aq})$. Moreover, the calculated Eh-pH stability field for the dimer $\left[\mathrm{TcO}(\mathrm{OH})_{2}\right]_{2}{ }^{\circ}$ (aq) expanded in Eh-pH space with increasing concentration of dissolved Tc(IV) due to its stoichiometric factor. Rard et al. (1999) found it difficult to evaluate the results of the study on which the dimer species and associated thermodynamic constant were based and therefore did not accept those results and the species $\left[\mathrm{TcO}(\mathrm{OH})_{2}\right]_{2}{ }^{\circ}(\mathrm{aq})$ for their thermodynamic database for technetium compounds.

Solubility processes may control the concentration of technetium in soils under reducing conditions. Figure 2.5 shows the Eh-pH conditions under which an aqueous solution containing $1 \times 10^{-7.5} \mathrm{~mol} / \mathrm{L}$ total dissolved technetium calculates to be oversaturated with technetium solids. Technetium(VII), as $\mathrm{TcO}_{4}^{-}$, is highly soluble, and does not form solubility-controlling phases in geochemical systems. In the Eh-pH region defined by the tan-colored area in Figure 2.5, the amorphous solid $\mathrm{TcO}_{2} \cdot 2 \mathrm{H}_{2} \mathrm{O}$ calculates to be oversaturated based on the available thermodynamic data and may precipitate at these Eh-pH conditions to limit the maximum concentration of dissolved technetium in soil.

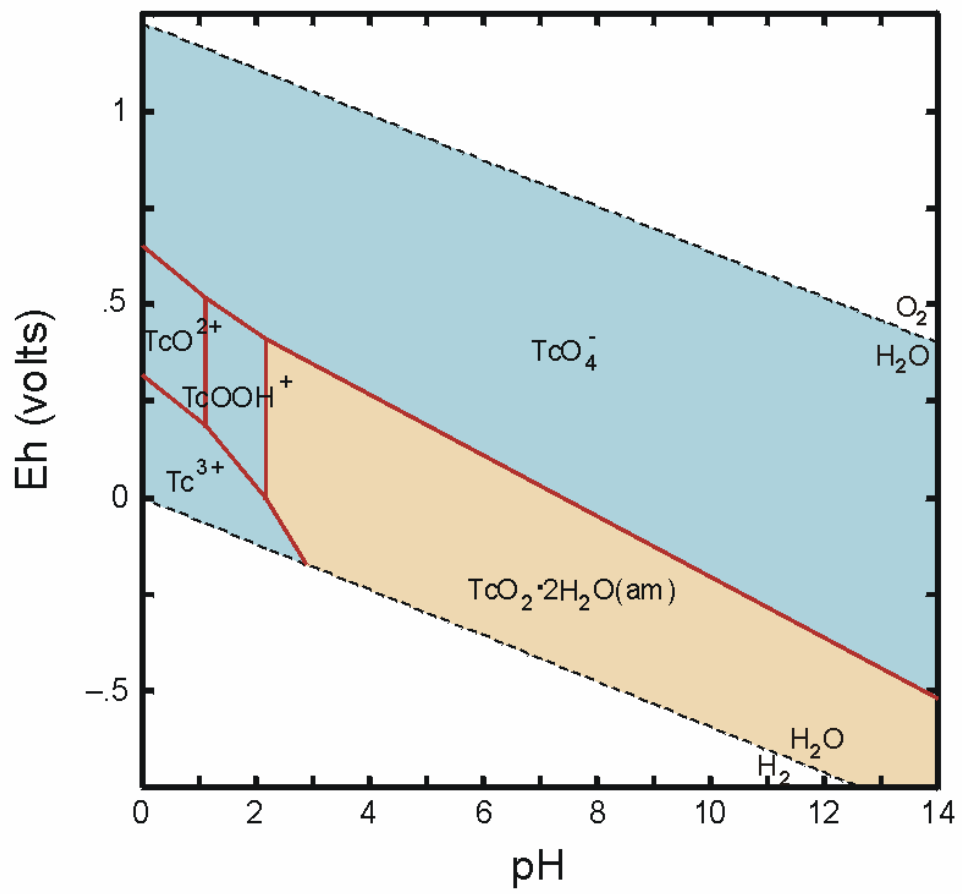

Figure 2.5. Diagram Showing Eh-pH Region (Tan Colored) that Calculates to be Oversaturated with Respect to the Solubility of Technetium Solids (diagram was calculated at a total concentration of $1 \times 10^{-7.5} \mathrm{~mol} / \mathrm{L}$ dissolved technetium at $25^{\circ} \mathrm{C}$ )

Numerous studies on the sorption of technetium on sediments, soils, pure minerals, oxide phases, and crushed rock materials have been conducted. An extensive review of these studies is presented in EPA (2003). These studies consist primarily of measurements of $\mathrm{K}_{\mathrm{d}}$ values for $\mathrm{Tc}(\mathrm{VII})$. The adsorption of $\mathrm{Tc}(\mathrm{VII})$ oxyanion $\mathrm{TcO}_{4}{ }^{-}$is expected to be very low to zero, i.e., $\mathrm{K}_{\mathrm{d}}$ 
values of $\approx 0 \mathrm{~mL} / \mathrm{g}$, at near neutral and basic $\mathrm{pH}$ conditions and to increase when $\mathrm{pH}$ values decrease to less than 5 . However, $\mathrm{K}_{\mathrm{d}}$ values for $\mathrm{Tc}(\mathrm{VII})$ sorbed on sediments high in organic matter can be considerable (Thibault et al. 1990). Wildung et al. (1974) determined that the sorption of $\mathrm{TcO}_{4}{ }^{-}$is positively correlated to the organic carbon content of soils, but studies of the effect that organic material has on the sorption of Tc(VII) in soils are limited. Measurable adsorption of $\mathrm{Tc}(\mathrm{VII})$ observed in experiments conducted with organic material as well as with crushed rock and Fe(II)-containing minerals has been attributed to the reduction of $\mathrm{Tc}(\mathrm{VII})$ to $\mathrm{Tc}(\mathrm{IV})$. Technetium(IV) is considered to be essentially immobile because it readily precipitates as sparingly soluble hydrous oxides and forms strong complexes with surface sites on iron and aluminum oxides and clays.

\subsubsection{Iodine-129 $\left({ }^{129} \mathrm{I}\right)$}

The environmental behavior of iodine has been reviewed by others, such as Lieser and Steinkopff (1989b), Whitehead (1984), Coughtrey et al. (1983), and Ames and Rai (1978). Although the environmental chemistry of iodine is normally assumed to be simple and well known, recent studies suggest that the fate and mobility of iodine in environmental systems may be more complex than expected. This complexity is caused by the multiple redox states of iodine that may exist under oxidizing conditions. The $-1,+5$, and molecular $\mathrm{I}_{2}$ oxidation states are those most relevant for iodine in environmental systems.

Figure 2.6 is an Eh-pH diagram that shows the dominant aqueous species of iodine predicted to present at $25 \mathrm{EC}$ and a total concentration of $1 \times 10^{-8} \mathrm{~mol} / \mathrm{L}$ dissolved iodine. In most aqueous environments, iodine is present as the iodide ion, $\mathrm{I}^{-}$. The stability range of $\mathrm{I}^{-}$extends almost over the entire $\mathrm{pH}$ and Eh range for the thermodynamic stability of water. In marine and highly oxidizing environments, such as surface waters and some oxygenated shallow groundwaters, iodine may be present in the +5 oxidation state as the iodate ion, $\mathrm{IO}_{3}{ }^{-}$. Under oxidizing, acidic conditions, molecular $\mathrm{I}_{2}{ }^{\circ}$ (aq) may form from the reduction of $\mathrm{IO}_{3}{ }^{-}$or the oxidation of $\mathrm{I}^{-}$.

Some iodine sorption studies suggest that the oxidation state of iodine may have an impact on the observed sorption behavior of iodine in soils. The organic contents and/or microbial processes may affect the redox reactions of iodine in soils. For example, studies, such as Skogerboe and Wilson (1981), indicate that fulvic acid derived from soil is capable of reducing molecular $\mathrm{I}_{2}{ }^{\mathrm{o}}(\mathrm{aq})$ and $\mathrm{IO}_{3}{ }^{-}$to $\mathrm{I}^{-}$under conditions generally characteristic of natural waters.

The volatilization of iodine from soil to the atmosphere may occur as a result of both chemical and microbiological processes (Whitehead 1984). The chemical processes generally result in molecular iodine or hydrogen iodide, and the microbiological processes yield organic compounds, such as methyl iodide. Methyl iodide is not strongly retained by soil components and is only slightly soluble in water (Whitehead 1984). 


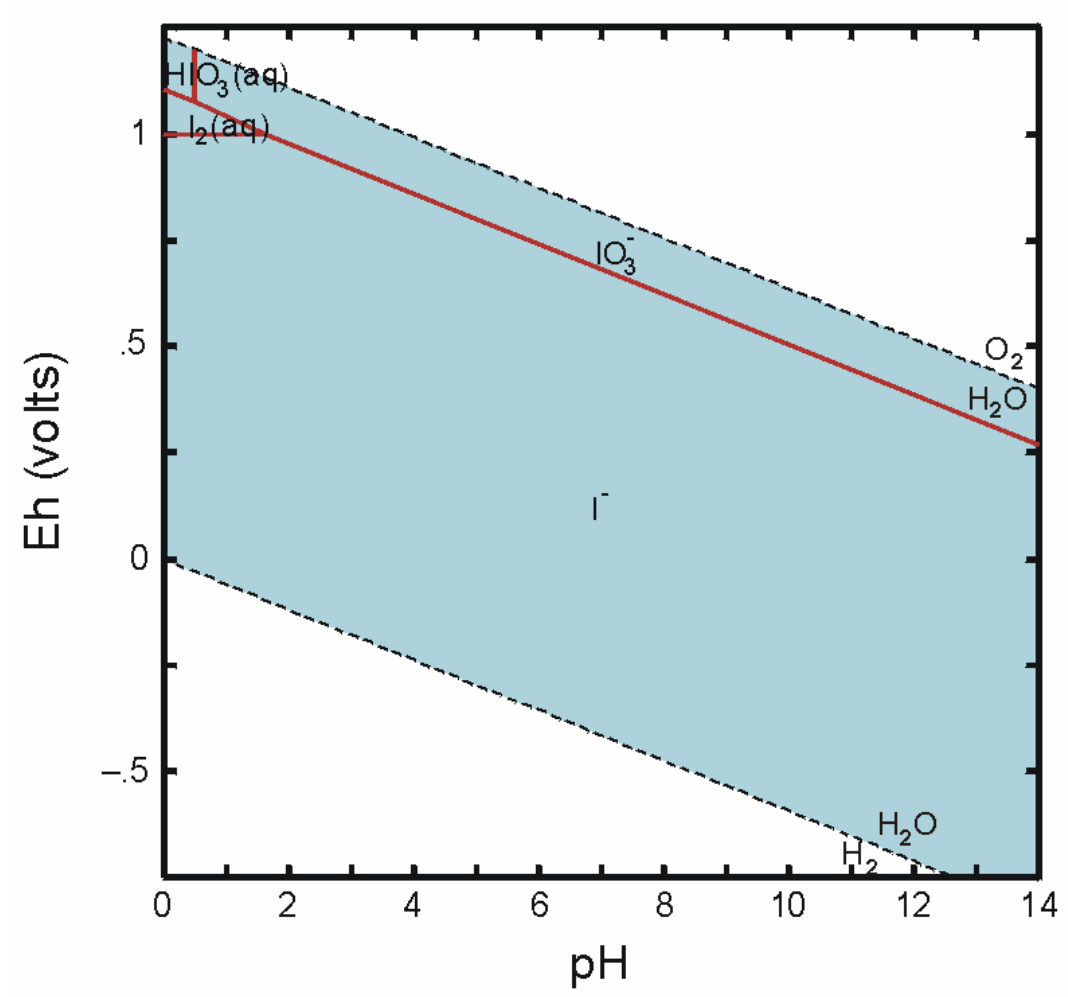

Figure 2.6. Eh-pH Diagram Showing Dominant Aqueous Species of Iodine (diagram was calculated at a total concentration of $1 \times 10^{-8} \mathrm{~mol} / \mathrm{L}$ dissolved iodine at $25^{\circ} \mathrm{C}$ )

The precipitation of iodine-containing solids is not likely to be an important process in soils due to the low concentrations of iodine in environmental systems and the high solubility of iodinecontaining minerals. Iodine can be found as a primary component in some rare, naturally occurring minerals that are associated with evaporite and brine deposits (Johnson 1994; Doner and Lynn 1977). The iodide is commonly present in substitution for other halogen elements, such as chloride and bromide, whereas iodate is typically associated with sulfate- or nitrate-type minerals. However, such minerals are expected to be highly soluble in soils.

A detailed review of iodine adsorption studies is given in EPA (2003). Iodine studies published before 1976 are reviewed in Onishi et al. (1981) and Ames and Rai (1978). The majority of these adsorption studies pertain to the adsorption of iodide. Adsorption of iodine species appears to be controlled in part by soil organic matter and in part by iron and aluminum oxides, with the adsorption of iodine becoming increasingly important under more acidic conditions. Numerous studies have been conducted in which $\mathrm{K}_{\mathrm{d}}$ values for iodide adsorption on soil have been reported along with associated $\mathrm{pH}$ values and/or soil organic carbon contents (Kaplan et al. 1996, 1998a, 1998b, 2000a, 2000b; Fukui et al. 1996; Bird and Schwartz 1996; Serne et al. 1993; Muramatsu et al. 1990; Sheppard and Thibault 1988; Gee and Campbell 1980). The results of these published studies suggest that the adsorption of iodide increases with increasing soil organic matter, but the majority $(>90 \%)$ of the reported $\mathrm{K}_{\mathrm{d}}$ values for iodide are limited to soils containing less than $0.2 \mathrm{wt} . \%$ organic matter contents. 
Although the extent of sorption is typically low, especially in systems containing little or no organic matter, $\mathrm{I}^{-}$and $\mathrm{IO}_{3}{ }^{-}$are sorbed to a measurable extent by soils and some oxide and sulfide minerals at near neutral and alkaline $\mathrm{pH}$ conditions. Values of $\mathrm{K}_{\mathrm{d}}$ for iodide have been reported in the range from 1 to $10 \mathrm{~mL} / \mathrm{g}$ for the $\mathrm{pH}$ range from 4 to 10 , but most of the reported $\mathrm{K}_{\mathrm{d}}$ values are typically less than $3 \mathrm{ml} / \mathrm{g}$. The adsorption behavior of $\mathrm{IO}_{3}{ }^{-}$also appears to be appreciably different from that of $\mathrm{I}^{-}$, in that $\mathrm{IO}_{3}{ }^{-}$sorbs much more strongly than $\mathrm{I}^{-}$to soil and mineral surfaces.

Because iodine is present as either the anions $\mathrm{I}^{-}$or $\mathrm{IO}_{3}{ }^{-}$in most soils, conventional wisdom suggests that their adsorption on soils and most individual mineral phases should be negligible at near neutral and alkaline $\mathrm{pH}$ conditions. Mechanisms causing this sorption behavior of iodine at these $\mathrm{pH}$ conditions are not completely understood. Some have proposed that this observed adsorption behavior in soils may be a result of the oxidation of $\mathrm{I}^{-}$and/or reduction of $\mathrm{IO}_{3}{ }^{-}$to the more reactive molecular $\mathrm{I}_{2}{ }^{\circ}$ (aq) and/or its hydrolysis products (Yu et al. 1996; Behrens 1982; Whitehead 1974). Some investigators believe that this iodine redox process may result from organic matter and/or microbial processes in the soils. For example, as noted previously, some researchers have found positive correlations between the adsorption of iodine and organic matter content in soils. In other studies, the iodine adsorption was determined to decrease when soils are treated with fungicide, bactericide, irradiation, or heat. Others have proposed that iodine adsorption was primarily a consequence of physical processes that are associated with the surfaces and entrapment in the micropores and structural cavities in the organic matter.

\subsubsection{Selenium-79 $\left({ }^{79} \mathrm{Se}\right)$}

The geochemistry and environmental behavior of selenium in soil, groundwater, and geological systems is reviewed by the National Academy of Sciences (NAS 1976), Rai et al. (1984), Elrashidi et al. (1989), Mayland et al. (1989), McNeal and Balistrieri (1989), and others. The aqueous speciation and possible solubility controls for selenium in soil systems are calculated and discussed by Rai et al. (1984) and Elrashidi et al. (1989).

Selenium can be found in the $-2,0,+4$, and +6 oxidation states (Baes and Mesmer 1976). The Eh-pH diagram in Figure 2.7 shows the dominant aqueous species for dissolved selenium. The diagram was calculated at $25^{\circ} \mathrm{C}$ using a concentration of $1 \times 10^{-8} \mathrm{~mol} / \mathrm{L}$ total dissolved selenium and the ligand concentrations listed in Table 2.2. Figure 2.7 is consistent with the Eh-pH diagram given for selenium inorganic aqueous species in Rai et al. (1984). As indicated in Figure 2.7, dissolved selenium will be present in the +6 oxidation state under oxidizing conditions as the dominant species $\mathrm{HSeO}_{4}{ }^{-}$and $\mathrm{SeO}_{4}{ }^{2-}$ at $\mathrm{pH}$ values less than and greater than 2 , respectively. Under moderately oxidizing to reducing conditions, the $\mathrm{Se}(\mathrm{IV})$ species $\mathrm{H}_{2} \mathrm{SeO}_{3}{ }^{\circ}$ (aq), $\mathrm{HSeO}_{3}{ }^{-}$, and $\mathrm{HSeO}_{3}{ }^{2-}$ calculate to be dominant at $\mathrm{pH}$ values less than approximately 2.5 , from 2.5 to 7 , and greater than 7, respectively. The $\mathrm{Se}(-2)$ species $\mathrm{H}_{2} \mathrm{Se}^{\mathrm{o}}$ (aq) and $\mathrm{HSe}^{-}$are the dominant aqueous species of selenium at $\mathrm{pH}$ values less than and greater than about 4, respectively, under highly reducing conditions. It is interesting to note that the Eh-pH diagram (Figure 2.7) indicates that dissolved selenium in the $-2,+4$, and +6 oxidation states will be present as anionic species at $\mathrm{pH}$ values greater than 4 under all redox conditions within the thermodynamic stability range of water. 
The formation of methylated forms of selenium, such as dimethyl selenide $\left(\mathrm{CH}_{3} \mathrm{SeCH}_{3}\right)$ and dimethyl diselenide $\left(\mathrm{CH}_{3} \mathrm{SeSeCH}_{3}\right)$, has been detected and studied in laboratory experiments and environmental systems (e.g., Chasteen 1998; Guo et al. 1999; Zhang et al. 1999; Zhang and Frankenberger 2000). Chasteen (1998) gives a detailed review of the volatile chemical species of selenium. Due to the relatively high vapor pressure of these compounds, the formation of methylated forms of selenium can be significant contributors to the mobility of selenium in environmental systems.

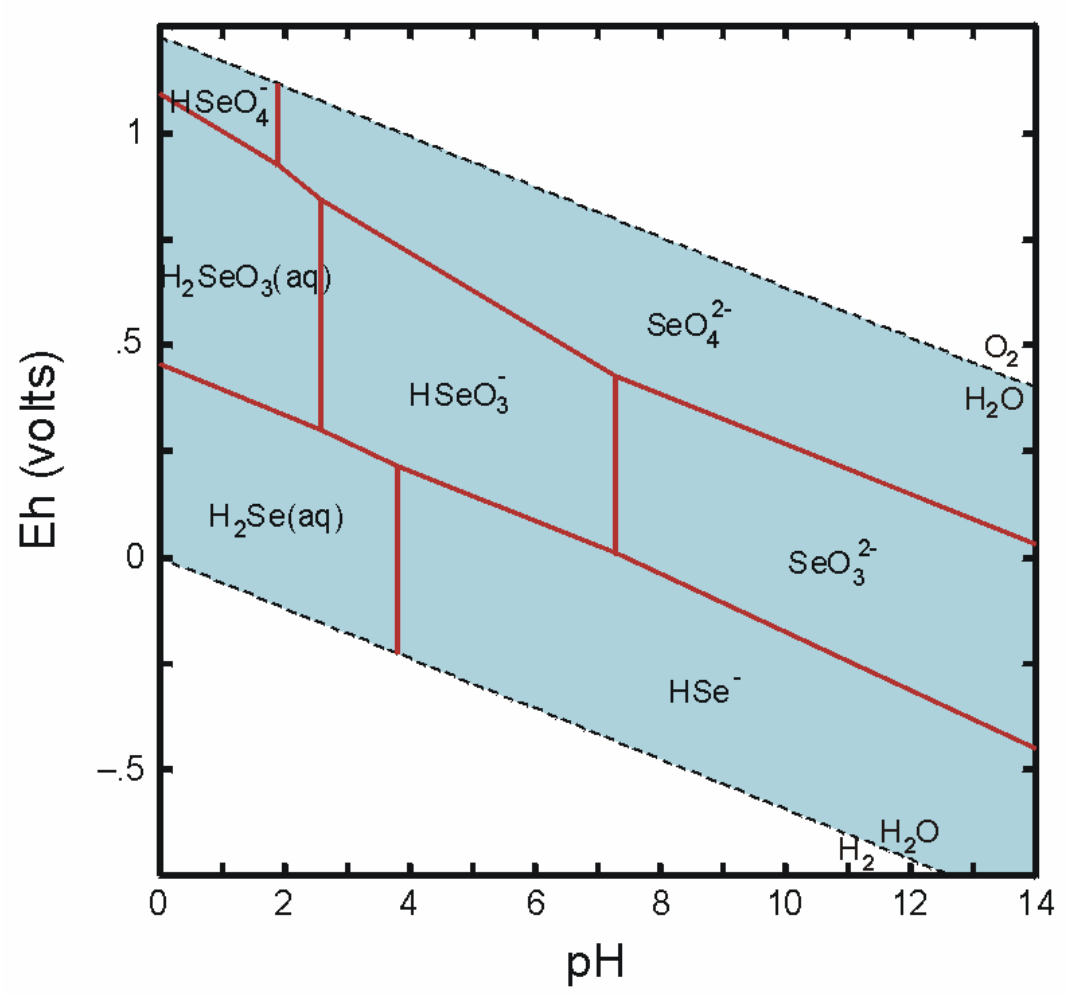

Figure 2.7. Eh-pH Diagram Showing Dominant Aqueous Species of Selenium (diagram was calculated at a total concentration of $1 \times 10^{-8} \mathrm{~mol} / \mathrm{L}$ dissolved selenium at $\left.25^{\circ} \mathrm{C}\right)$

In some soil systems under moderately and highly reducing conditions, the concentration of dissolved selenium may be controlled by the precipitation of selenium solids, such as elemental selenium $\left(\mathrm{Se}^{\mathrm{o}}\right)$. Figure 2.8 shows the Eh-pH region (tan-colored area) that calculates to be oversaturated with respect to solid elemental selenium $\left(\mathrm{Se}^{\circ}\right)$ for an aqueous solution containing a total concentration of dissolved selenium of $10^{-8} \mathrm{~mol} / \mathrm{L}$ and the ligand concentrations in Table 2.2. Figure 2.8 is essentially identical to the $\mathrm{Eh}-\mathrm{pH}$ solubility diagram given in McNeal and Balistrieri (1989). These calculations indicate that elemental selenium is relatively insoluble in soils over a wide range of $\mathrm{pH}$ conditions under moderately reducing conditions and would limit the mobility of selenium in such environmental systems. In highly reducing and organic-rich systems containing dissolved sulfide or bisulfide, selenium-sulfide solids and metal selenides, such as ferroselite $\left(\mathrm{FeSe}_{2}\right)$, are insoluble and would limit the concentration of dissolved selenium and its mobility in such soil systems. 
Selenium can be reduced to its lower oxidation states by abiotic and biotic processes. Studies by Losi et al. (1998), Nelson et al. (1996), Poole and Porter (1999), and others show that dissolved selenium can be reduced by bacteria processes. These reactions can result in the bioreduction of selenium to insoluble forms, such as solid elemental selenium $\left(\mathrm{Se}^{\mathrm{o}}\right)$ or $\mathrm{S}_{1-\mathrm{x}} \mathrm{Se}_{\mathrm{x}}$, which will limit the mobility and bioavailability of selenium in soil systems.

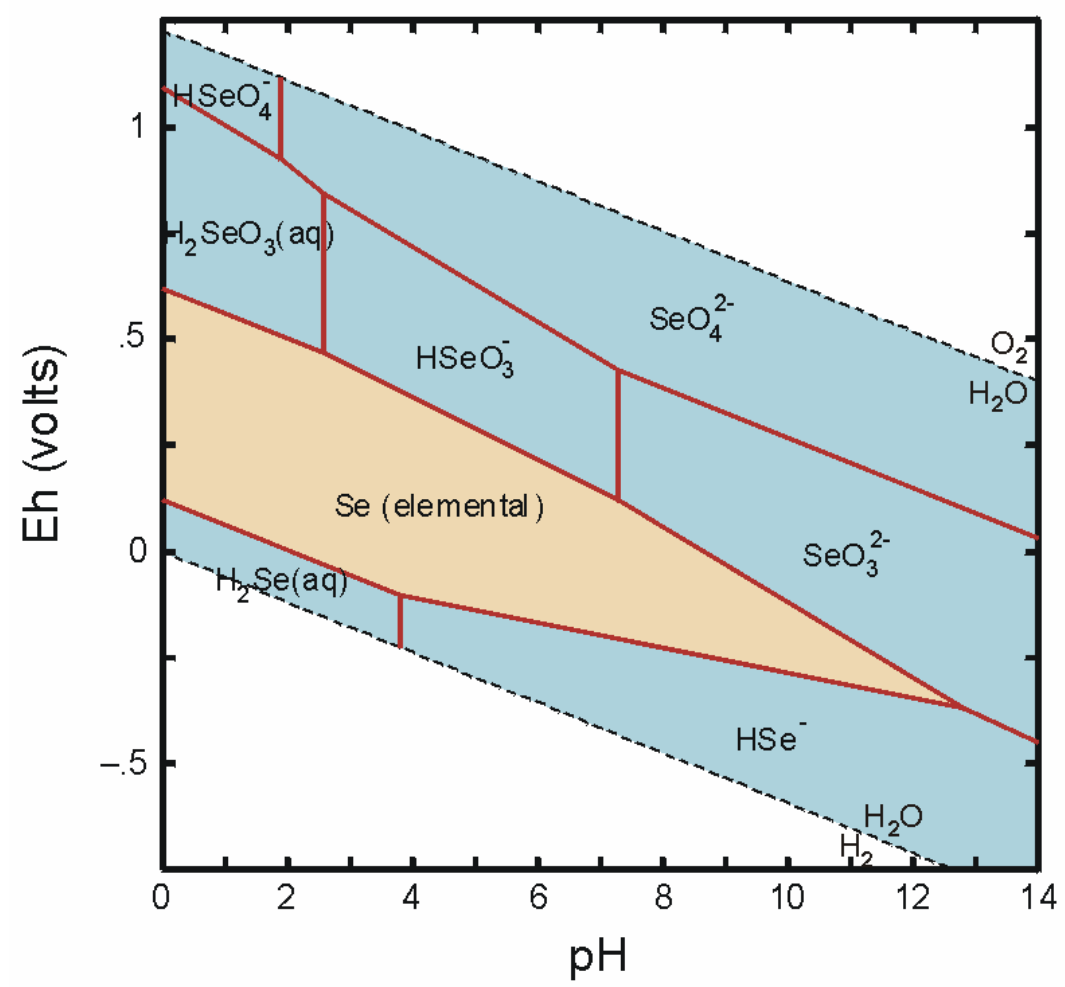

Figure 2.8. Diagram Showing Eh-pH Region (tan colored) that Calculates to be Oversaturated with Respect to the Solubility of Elemental Selenium (diagram was calculated at a total concentration of $1 \times 10^{-8} \mathrm{~mol} / \mathrm{L}$ dissolved selenium at $25^{\circ} \mathrm{C}$ )

The concentration of selenium in most soil systems under oxidizing conditions is likely controlled by adsorption processes. The adsorption of selenium has not been studied extensively. Thibault et al. (1990) do not identify any $\mathrm{K}_{d}$ values for selenium in their critical review and compilation. Because the dominant aqueous species of $\mathrm{Se}(\mathrm{IV})$ and $\mathrm{Se}(\mathrm{VI})$ are anionic over the $\mathrm{pH}$ range of most soils (see Figure 2.7), the adsorption of selenium to mineral surfaces would be expected to be minimal to zero in most soil systems under oxidizing and moderately reducing conditions. However, published adsorption studies indicate that hydrous oxides of iron and aluminum and amorphous alumino-silicates have a high sorptive affinity for $\mathrm{Se}(\mathrm{VI})$ and Se(IV) (Rai et al. 1984 and references therein). The limited number of $\mathrm{K}_{\mathrm{d}}$ data listed for selenium in compilations, such as Rai et al. (1984) and Cantrell et al. (2002), typically range from a few milliliters per gram to several tens of milliliters per gram. The adsorption of selenium is also dependent on $\mathrm{pH}$ with adsorption being strong under acidic conditions and 
decreasing with increasing $\mathrm{pH}$. This $\mathrm{pH}$ dependency is consistent with that known for other radionuclides and inorganic contaminants present primarily as anionic species.

\subsubsection{Tin-126 $\left({ }^{126} \mathrm{Sn}\right)$}

The geochemistry of tin has not been studied extensively, and little information exists regarding its environmental behavior in soil and groundwater systems. Tin can exist in compounds in several oxidation states from -4 to +4 . Only the +2 and +4 states are important for tin in natural systems (Baes and Mesmer 1976).

Figure 2.9 is an Eh-pH diagram that shows the dominant aqueous species of tin predicted to be present at a total concentration of $1 \times 10^{-8} \mathrm{~mol} / \mathrm{L}$ dissolved tin and the ligand concentrations listed in Table 2.2. The speciation calculations indicate that dissolved tin would be present in the +4 oxidation state as the aqueous complex $\mathrm{Sn}(\mathrm{OH})_{4}{ }^{\mathrm{o}}$ (aq) in most aqueous environments. Under acidic, highly reducing conditions, dissolved tin would be present in the reduced +2 state as the uncomplexed ion $\mathrm{Sn}^{2+}$ (Figure 2.9).

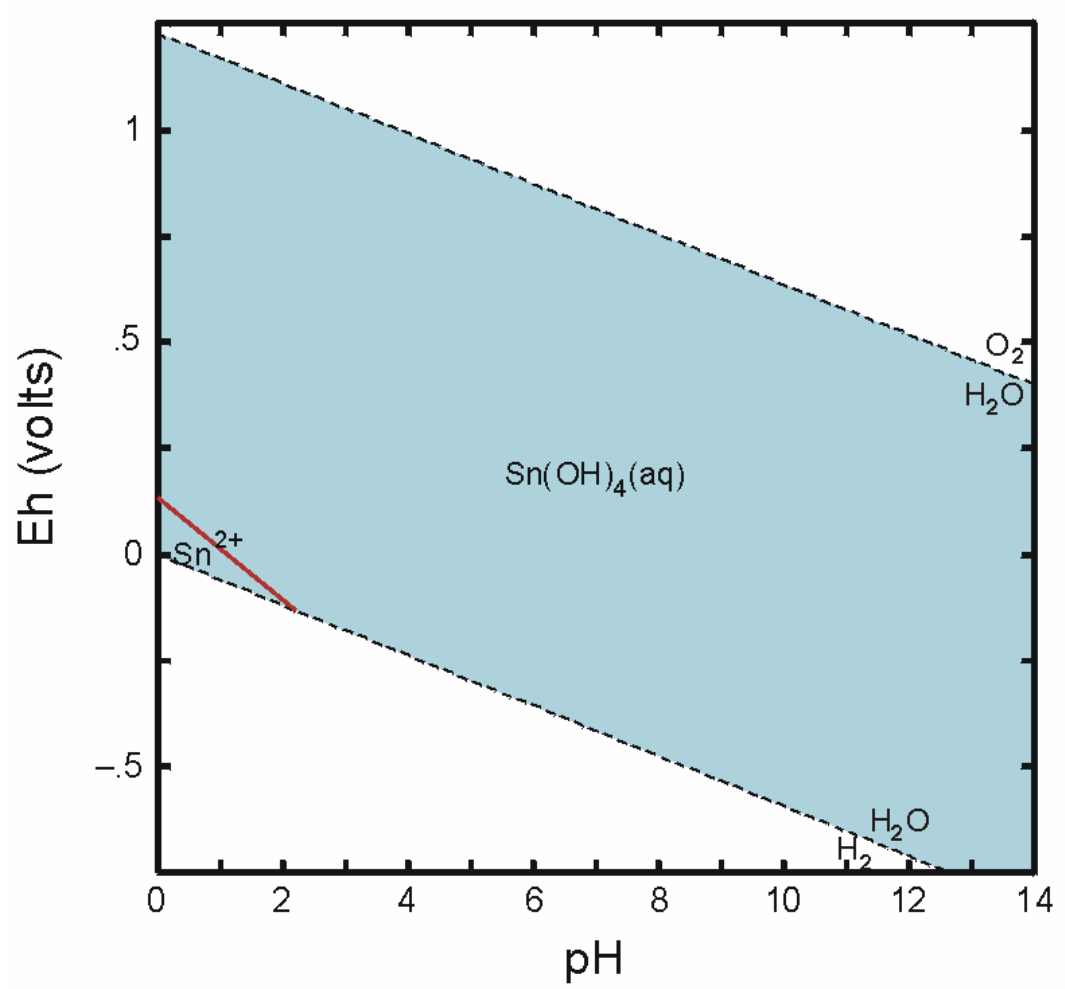

Figure 2.9. Eh-pH Diagram Showing Dominant Aqueous Species of Tin (diagram was calculated at a total concentration of $1 \times 10^{-8} \mathrm{~mol} / \mathrm{L}$ dissolved tin at $25^{\circ} \mathrm{C}$ )

Information regarding the aqueous speciation of tin is extremely limited. Séby et al. (2001) recently completed a critical review of the thermodynamic data for inorganic tin species. Although their recommended values for tin species are not included in the current thermodynamic database that we used with The Geochemist's Workbench ${ }^{\circledR}$ software package, 
their speciation calculations also indicate that $\mathrm{Sn}^{2+}$ and its hydrolysis products are limited to very reducing conditions at or below the stability boundary for the breakdown of water to $\mathrm{H}_{2}(\mathrm{~g})$.

Séby et al. (2001) also note that information regarding the hydrolysis of $\mathrm{Sn}$ (IV) and speciation in general is limited due to the low solubility of $\mathrm{SnO}_{2}$ (the mineral cassiterite) and its precipitation in laboratory studies of Sn(IV) speciation. Ashby and Craig (1988) review the available information on the methylation of tin. Their review suggests that tin methylation may occur by abiotic and biotic process and thus may contribute to the mobility of tin in environmental conditions.

Figure 2.10 shows the Eh-pH regions (tan-colored areas) in which tin solids calculate to be oversaturated for a total concentration of $1 \times 10^{-8} \mathrm{~mol} / \mathrm{L}$ dissolved tin based on the available thermodynamic data and the ligand concentrations listed in Table 2.2. The calculations indicate that berndtite $\left(\mathrm{SnS}_{2}\right)$ may be a solubility control for tin in environmental systems that are highly reducing and contain dissolved sulfide. Cassiterite calculates to oversaturated over the Eh-pH region indicated by $\mathrm{Sn}(\mathrm{OH})_{4}{ }^{\circ}(\mathrm{aq})$ in Figure 2.10 when the total concentration of dissolved tin is increased to $1 \times 10^{-7.5} \mathrm{~mol} / \mathrm{L}$.

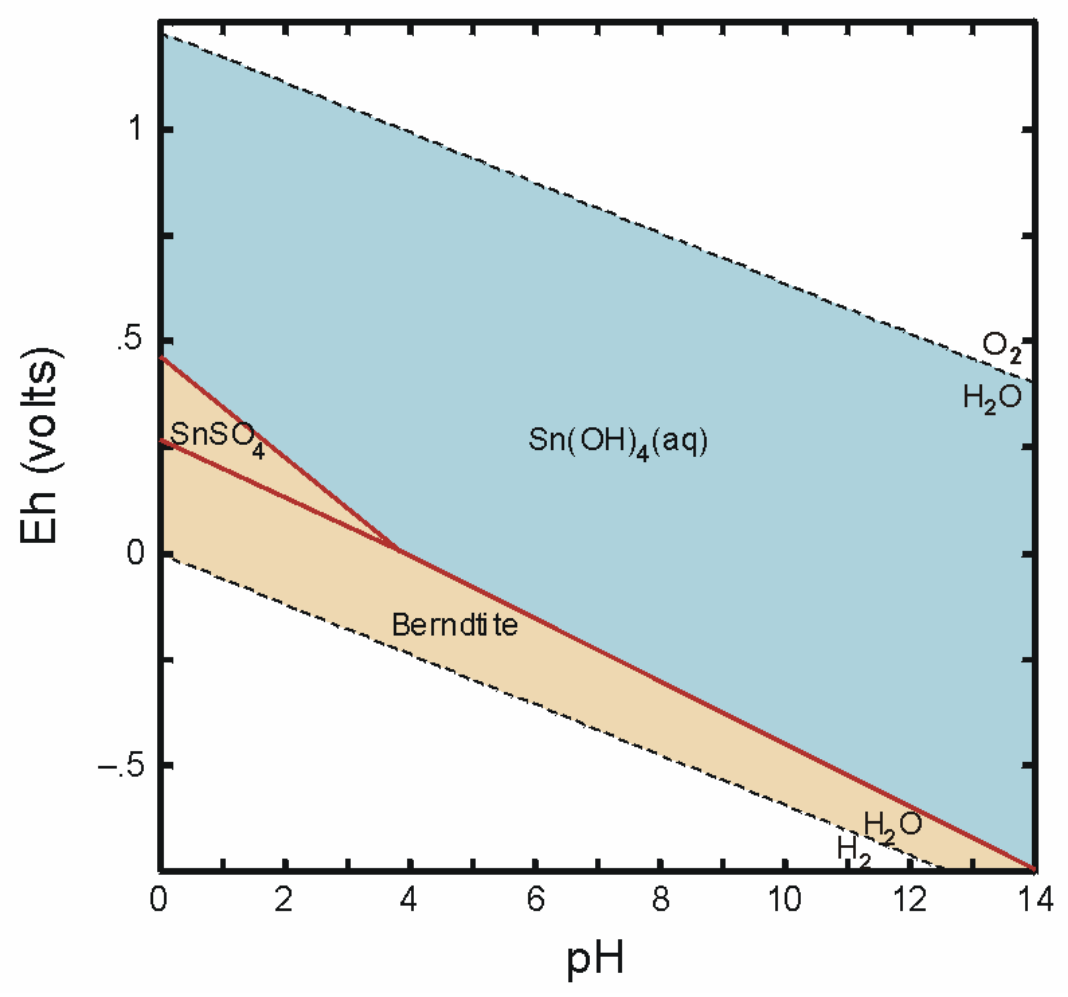

Figure 2.10. Diagram Showing Eh-pH Region (Tan Colored) that Calculates to be Oversaturated with Respect to the Solubility of Tin Solids (diagram was calculated at a total concentration of $1 \times 10^{-8} \mathrm{~mol} / \mathrm{L}$ dissolved tin at $25^{\circ} \mathrm{C}$ ) 
No information was identified regarding the adsorption behavior of $\mathrm{Sn}(\mathrm{IV})$ in soils. Given that tin will be present in the +4 oxidation state in most environmental systems, tin is likely to be at least moderately sorbed in soils due to the low solubility of cassiterite, assuming that no anionic aqueous complexes form.

\subsubsection{Thorium-232 $\left({ }^{232} \mathrm{Th}\right)$}

The geochemical behavior of thorium in natural systems has been reviewed by others, such as EPA (1999b), Lieser and Hill (1992), Langmuir and Herman (1980), Onishi et al. (1981), and Ames and Rai (1978). Thorium occurs only in the +4 oxidation state in natural soil-water environments. Figure 2.11 is an Eh-pH diagram that shows the dominant aqueous species for dissolved thorium. The diagram was calculated at $25^{\circ} \mathrm{C}$ using a concentration of $1 \times 10^{-8} \mathrm{~mol} / \mathrm{L}$ total dissolved thorium and the ligand concentrations listed in Table 2.2. The thermodynamic data used to calculate the Eh-pH diagram were from a critical review by Langmuir and Herman (1980) of the available thermodynamic data for thorium-containing aqueous species and solids. Dissolved thorium forms a variety of hydroxyl complexes at $\mathrm{pH}$ values above 3 (Baes and Mesmer 1976; Cotton and Wilkinson 1980). In the absence of dissolved ligands other than hydroxide, the uncomplexed ion $\mathrm{Th}^{4+}$ calculates to be the dominant aqueous species at $\mathrm{pH}$ values less than about 3.5. At $\mathrm{pH}$ values greater than 3.5, the hydrolysis of thorium is dominated by the aqueous species $\mathrm{Th}(\mathrm{OH})_{2}{ }^{2+}$ and $\mathrm{Th}(\mathrm{OH})_{4}{ }^{\mathrm{o}}(\mathrm{aq})$ with increasing $\mathrm{pH}$. For conditions used to calculate Figure 2.11, the neutral hydroxide complex $\mathrm{Th}(\mathrm{OH})_{4}{ }^{\circ}$ (aq) dominates the aqueous speciation of dissolved thorium at $\mathrm{pH}$ values greater than 5. Baes and Mesmer (1976) also note that the large effective charge of the $\mathrm{Th}^{4+}$ ion can result in the formation of polynuclear thoriumhydrolysis complexes with increasing concentrations of dissolved thorium. Langmuir and Herman (1980) list estimated thermodynamic values for the thorium polynuclear hydrolyzed species $\mathrm{Th}_{2}(\mathrm{OH})_{2}{ }^{6+}, \mathrm{Th}_{4}(\mathrm{OH})_{8}{ }^{8+}$, and $\mathrm{Th}_{6}(\mathrm{OH})_{15}{ }^{9+}$. Although our present knowledge of the formation of these polynuclear species is poor, they are believed to play a role in mobility of thorium in natural soil-water systems.

In addition to hydrolytic complexes, dissolved thorium can form strong various aqueous complexes with inorganic ligands, such as dissolved carbonate, fluoride, phosphate, chloride, nitrate, and organic ligands. As shown in Figure 2.11, the complex $\mathrm{ThF}_{2}{ }^{2+}$ calculates to be dominant at $\mathrm{pH}$ values less than 5 for the ligand concentrations used for these speciation calculations. Thorium phosphate complexes also calculate to be important at acidic and nearneutral $\mathrm{pH}$ conditions. Although phosphate complexation is expected to have a role in the mobility of thorium in this $\mathrm{pH}$ range of $\mathrm{pH}$ values, the adequacy of the thermodynamic constants tabulated for thorium phosphate complexes in Langmuir and Herman (1980) are suspect, and may over predict the stability of these complexes. Studies, such as LaFlamme and Murray (1987) and Rai et al. (1995), completed since the review by Langmuir and Herman (1980) indicate the presence of dissolved thorium carbonate complexes and their importance to the solution chemistry of thorium. Östhols et al. (1994) have determined thermodynamic constants

for the thorium carbonate complexes $\mathrm{Th}(\mathrm{OH})_{3} \mathrm{CO}_{3}{ }^{-}$and $\mathrm{Th}\left(\mathrm{CO}_{3}\right)_{5}{ }^{6-}$, but these species and associated stability constants were in the thermodynamic database used to calculate the Eh-pH diagram in Figure 2.11. 


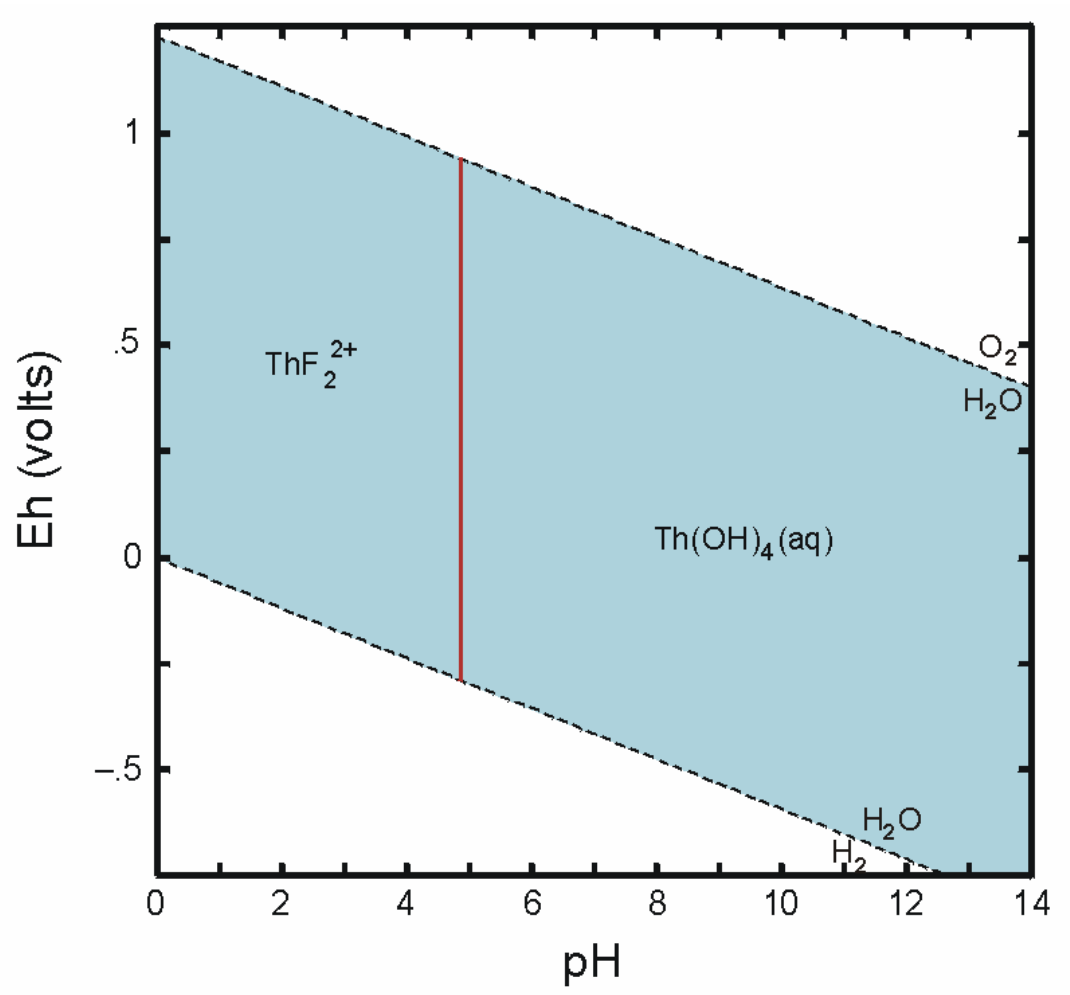

Figure 2.11. Eh-pH Diagram Showing Dominant Aqueous Species of Thorium (diagram was calculated at a total concentration of $1 \times 10^{-8} \mathrm{~mol} / \mathrm{L}$ dissolved thorium at $\left.25^{\circ} \mathrm{C}\right)$

Thorium is considered to be sparingly soluble in most environmental systems. The main thorium-containing minerals, thorite $\left([\mathrm{Th}, \mathrm{U}, \mathrm{Ce}, \mathrm{Fe}\right.$, etc. $\left.] \mathrm{SiO}_{4}\right)$, thorianite (crystalline $\left.\mathrm{ThO}_{2}\right)$, monazite ([Ce,La,Th] $\left.\mathrm{PO}_{4}\right)$ and zircon $\left(\mathrm{ZrSiO}_{4}\right)$, are resistant to chemical weathering and do not dissolve readily at low-temperature in surface and groundwaters. Figure 2.12 shows the Eh-pH conditions for which water containing $1 \times 10^{-8} \mathrm{~mol} / \mathrm{L}$ total dissolved thorium calculates to be oversaturated with respect to crystalline thorianite. However, because these minerals form at temperature and pressure conditions associated with igneous and metamorphic rocks (Frondel 1958; Deer et al. 1967), it is unlikely that the thermodynamic equilibrium solubilities of these minerals will control the concentration of dissolved thorium in low-temperature soil systems. The maximum concentration of dissolved thorium that may occur in low-temperature aqueous systems may be controlled by the solubility of hydrous thorium oxide. The solubility of hydrous thorium oxide has been studied experimentally by Ryan and Rai (1987), Felmy et al. (1991), and Rai et al. (1995). It is known to precipitate in laboratory experiments conducted at low temperature, oversaturated conditions over several weeks. If this solid precipitates in a natural environment, it will likely alter with time to a more crystalline solid that has a lower solubility.

Thorium concentrations in soil systems may also be controlled to very low levels less than a few micrograms per liter) by adsorption processes. Iron and manganese oxides are expected to be important adsorbents of thorium. Humic substances are considered particularly important in the adsorption of thorium (Gascoyne 1982). Thibault et al. (1990) compiled and reviewed published $\mathrm{K}_{\mathrm{d}}$ data for thorium as a function of soil type and list $\mathrm{K}_{\mathrm{d}}$ values for thorium that range from 207 
to $1.3 \times 10^{7} \mathrm{~mL} / \mathrm{g}$. However, as cautioned in EPA (1999b), the studies resulting in these very large $K_{d}$ values should be used with caution in case the initial thorium concentrations used for the measurements were too great, and precipitation of a thorium solid, e.g., hydrous thorium oxide, had occurred during the equilibration with soil. Thorium adsorption studies by LaFlamme and Murray (1987) indicated a strong influence of carbonate alkalinity on thorium adsorption. In their experiments at $\mathrm{pH} 9$, LaFlamme and Murray (1987) observed a decrease of thorium adsorption with the addition of carbonate alkalinity. They attributed this decrease in thorium adsorption to the competition for surface sites by $\mathrm{CO}_{3}{ }^{2-}$ and $\mathrm{HCO}_{3}{ }^{-}$and the formation of soluble thorium-carbonate anionic complexes.

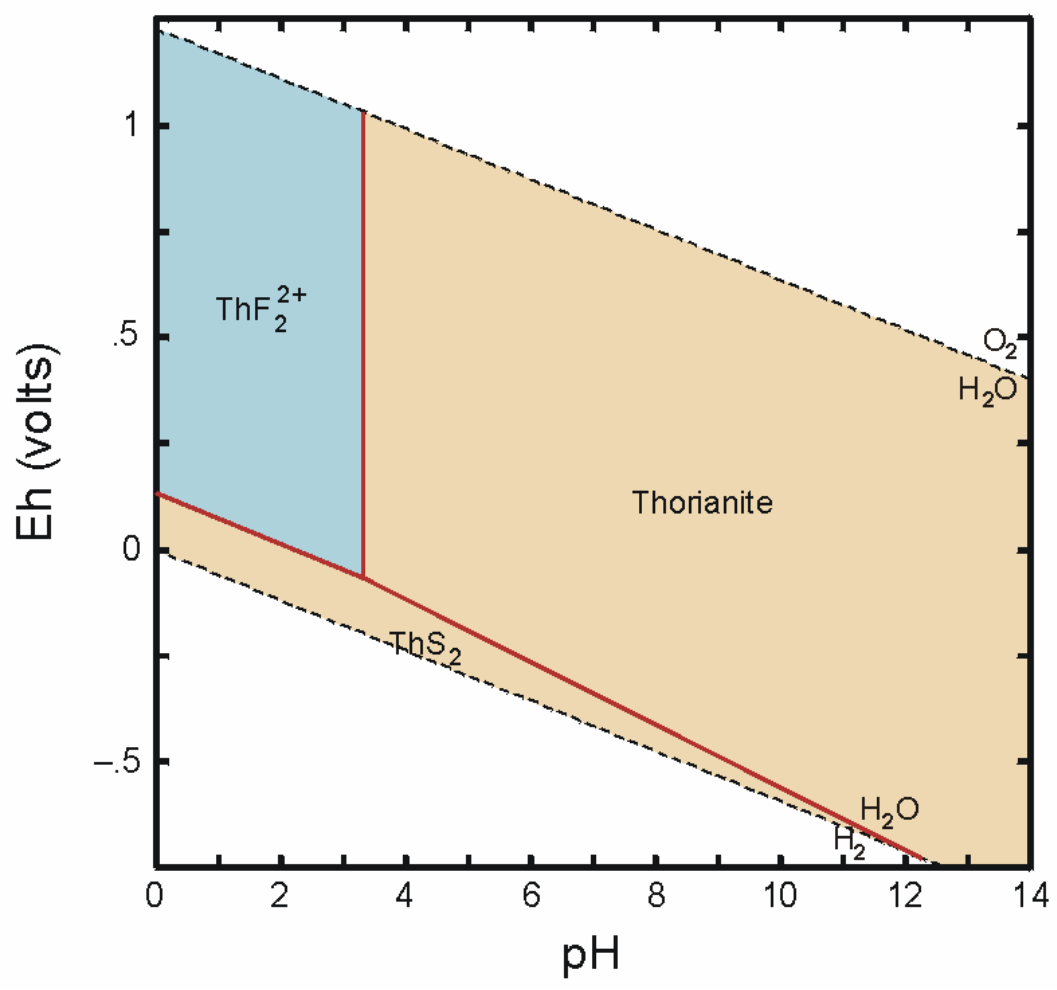

Figure 2.12. Diagram Showing Eh-pH Region (tan colored) that Calculates to be Oversaturated with Respect to the Solubility of Thorianite $\left(\mathrm{ThO}_{2}\right)($ diagram was calculated at a total concentration of $1 \times 10^{-8} \mathrm{~mol} / \mathrm{L}$ dissolved thorium at $\left.25^{\circ} \mathrm{C}\right)$

\subsubsection{Uranium-235 $\left({ }^{235} \mathrm{U}\right)$}

The geochemical behavior of uranium has received extensive study due to the importance of uranium as an energy source and as a geochronology indicator. There have been several published reviews of the geochemical behavior of uranium. The review by Langmuir (1978) and an updated discussion in Langmuir (1997) are particularly noteworthy. In 1999, an extensive compilation of detailed reviews on the mineralogical, geochemical, and environmental behavior of uranium was published in Burns and Finch (1999). 
Uranium can exist in the $+3,+4,+5$, and +6 oxidation states in aqueous environments. Uranium(VI), i.e., uranyl, $\mathrm{UO}_{2}{ }^{2+}$, and $\mathrm{U}(\mathrm{IV})$ are the most common oxidation states of uranium in natural environments. Uranium will exist in the +6 oxidation state under oxidizing to mildly reducing environments. Uranium(IV) is stable under reducing conditions and is considered relatively immobile because $\mathrm{U}(\mathrm{IV})$ forms sparingly soluble minerals, such as uraninite $\left(\mathrm{UO}_{2}\right)$. Dissolved U(III) easily oxidizes to U(IV) under most reducing conditions found in nature. The $\mathrm{U}(\mathrm{V})$ aqueous species $\left(\mathrm{UO}_{2}{ }^{+}\right)$readily disproportionates to $\mathrm{U}(\mathrm{IV})$ and $\mathrm{U}(\mathrm{VI})$. As with the redox of technetium, the reduction of U(VI) to U(IV) by abiotic and biotic processes has recently received considerable attention because the oxidation state of uranium has a significant effect on its mobility in waste streams and the natural environment. These reaction processes are the basis for certain remediation technologies, such as permeable barriers composed of zero-valent iron particles, i.e., as metallic iron, or sodium-dithionite-reduced soils. Microbial reduction of U(VI) has also been suggested as a potential mechanism for removal of uranium from contaminated waters and soils, e.g., Lovley (1993, 1995). Suzuki and Banfield (1999) provide a detailed review and extensive reference list on the interactions between uranium and microorganisms.

The Eh-pH diagram in Figure 2.13 shows the dominant aqueous species for dissolved uranium. The diagram was calculated at $25^{\circ} \mathrm{C}$ using a concentration of $1 \times 10^{-8} \mathrm{~mol} / \mathrm{L}$ total dissolved uranium and the ligand concentrations listed in Table 2.2. The aqueous speciation of $\mathrm{U}(\mathrm{VI})$ in carbonate-containing waters at near neutral and basic higher $\mathrm{pH}$ values is dominated by a series of strong anionic aqueous carbonate complexes [e.g., $\mathrm{UO}_{2} \mathrm{CO}_{3}{ }^{\circ}(\mathrm{aq}), \mathrm{UO}_{2}\left(\mathrm{CO}_{3}\right)_{2}{ }^{2-}$, and $\left.\mathrm{UO}_{2}\left(\mathrm{CO}_{3}\right)_{3}{ }^{4-}\right]$. Because anions do not readily adsorb to mineral surfaces at basic $\mathrm{pH}$ conditions, the formation of anionic $\mathrm{U}(\mathrm{VI})$ carbonate complexes at $\mathrm{pH}$ values greater than 6 result in an increase in U(VI) solubility, decreased U(VI) adsorption, and thus increased mobility of uranium. The Hanford vadose zone and upper unconfined aquifer environments contain adequate carbonate concentrations to have these uranyl carbonate complexes dominate the aqueous speciation of uranium. Under reducing conditions, the speciation of U(IV) is dominated by the neutral aqueous species $\mathrm{U}(\mathrm{OH})_{4}{ }^{\circ}$ (aq) at $\mathrm{pH}$ values greater than 2 .

In addition to dissolved carbonate, uranium can also form stable complexes with other naturally occurring inorganic and organic ligands. For example, Sandino and Bruno (1992) showed that $\mathrm{UO}_{2}{ }^{2+}$-phosphate complexes $\left[\mathrm{UO}_{2} \mathrm{HPO}_{4}{ }^{\circ}\right.$ (aq) and $\left.\mathrm{UO}_{2} \mathrm{PO}_{4}{ }^{-}\right]$could be important in aqueous systems with a pH between 6 and 9 when the total concentration ratio $\mathrm{PO}_{4}($ total $) / \mathrm{CO}_{3}$ (total) is greater than 0.1 . Complexes with sulfate, fluoride, and possibly chloride are potentially important uranyl species where concentrations of these anions are high. However, their stability is considerably less than the carbonate and phosphate complexes (Grenthe et al. 1992). Organic complexes may also be important to uranium aqueous chemistry, thereby increasing their solubility and mobility. The uncomplexed uranyl ion has a greater tendency to form complexes with fulvic and humic acids than many other metals with a +2 valence (Kim 1986). This has been attributed to the greater "effective charge" of the uranyl ion compared to other divalent metals. Kim (1986) also concluded that the tendency for $\mathrm{U}^{4+}$ to form humic- or fulvic-acid complexes is less than its tendency to hydrolyze or form carbonate complexes based on comparison of stability constants. 


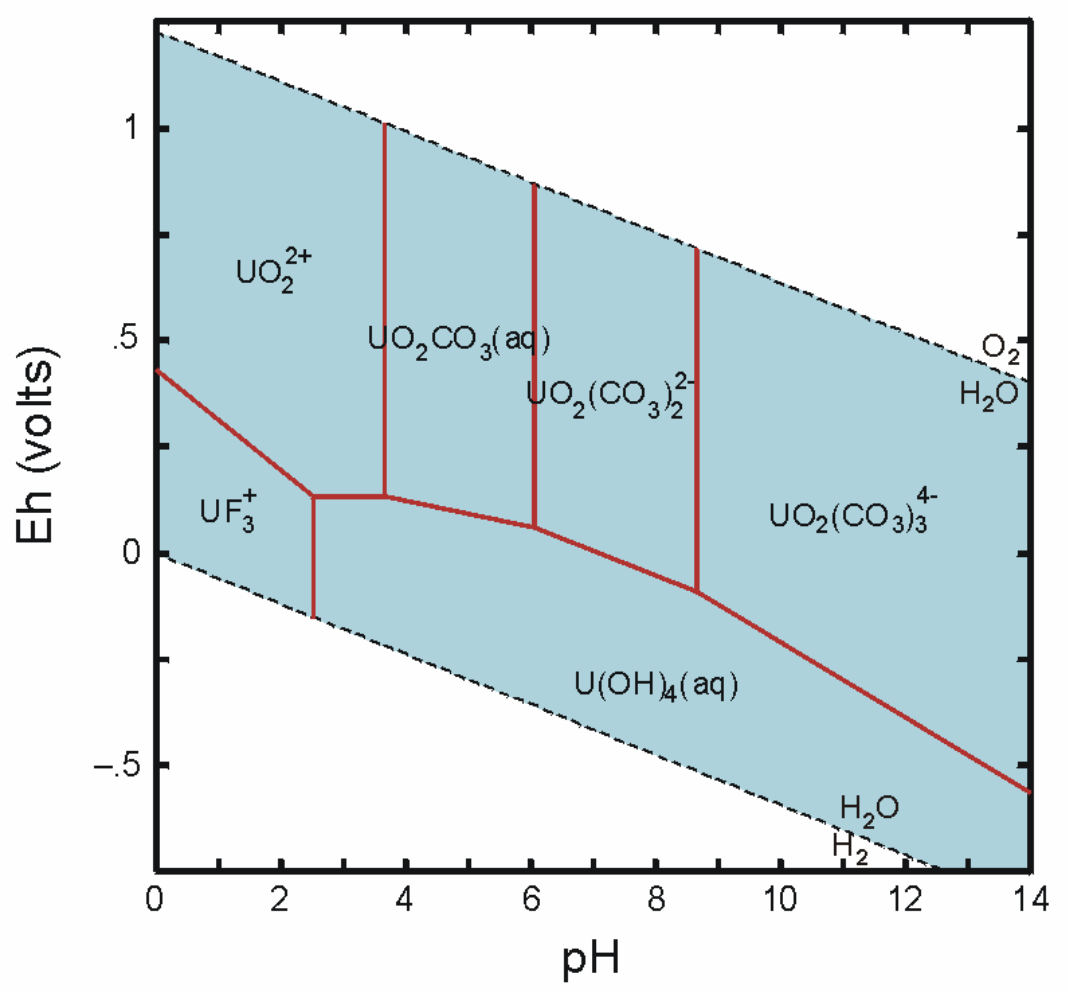

Figure 2.13. Eh-pH Diagram Showing Dominant Aqueous Species of Uranium (diagram was calculated at a total concentration of $1 \times 10^{-8} \mathrm{~mol} / \mathrm{L}$ dissolved uranium at $\left.25^{\circ} \mathrm{C}\right)$

Uranium mineral precipitation and coprecipitation processes may also be important for some environmental conditions, and several uranium (co)precipitates may form, depending on the geochemical conditions (Finch and Murakami 1999; Falck 1991; Frondel 1958). Uranium(IV) is considered relatively immobile under reducing conditions because U(IV) readily precipitates as sparingly soluble minerals, such as uraninite, which has compositions ranging from $\mathrm{UO}_{2}$ to $\mathrm{UO}_{2.25}$. Figure 2.14 shows the Eh-pH region (tan-colored area) in which uraninite $\left(\mathrm{UO}_{2}\right)$ calculates to be oversaturated for a total concentration of $1 \times 10^{-8} \mathrm{~mol} / \mathrm{L}$ dissolved uranium based on the available thermodynamic data. In geologic systems represented by these Eh-pH conditions (tan-colored area in Figure 2.14), uraninite may precipitate and limit the maximum concentration of dissolved uranium to $1 \times 10^{-8} \mathrm{~mol} / \mathrm{L}$ or less in those soils.

Solubility processes may also be particularly important for the environmental behavior of U(VI) under oxidizing conditions in those soils that become partially saturated with water or completely dry between periods of recharge, such as the surface soils and vadose-zone sediments. Under these conditions, the concentration of uranium in the residue pore fluids may exceed the solubility limits for $\mathrm{U}(\mathrm{VI})$-containing minerals and/or coprecipitates with other minerals, such as iron oxides. Potentially important mineral solubility controls for $\mathrm{U}(\mathrm{VI})$ include compreignacite $\left(\mathrm{K}_{2} \mathrm{U}_{6} \mathrm{O}_{19} \cdot 11 \mathrm{H}_{2} \mathrm{O}\right)$, uranophane $\left[\mathrm{Ca}\left(\mathrm{UO}_{2}\right)_{2}\left(\mathrm{SiO}_{3}\right)_{2}(\mathrm{OH})_{2} \cdot 5 \mathrm{H}_{2} \mathrm{O}\right]$, boltwoodite $\left[\mathrm{K}\left(\mathrm{H}_{3} \mathrm{O}\right) \mathrm{UO}_{2}\left(\mathrm{SiO}_{4}\right) \cdot 1.5 \mathrm{H}_{2} \mathrm{O}\right]$, sklodowskite $\left[\mathrm{Mg}\left(\mathrm{UO}_{2}\right)_{2}\left(\mathrm{SiO}_{3}\right)_{2}(\mathrm{OH})_{2} \cdot 5 \mathrm{H}_{2} \mathrm{O}\right]$, becquerelite $\left(\mathrm{CaU}_{6} \mathrm{O}_{19} \cdot 10 \mathrm{H}_{2} \mathrm{O}\right)$, carnotite $\left[\left(\mathrm{K}_{2}\left(\mathrm{UO}_{2}\right)_{2}\left(\mathrm{VO}_{4}\right)_{2} \cdot 3 \mathrm{H}_{2} \mathrm{O}\right]\right.$, schoepite $\left(\mathrm{UO}_{3} \mathrm{~A} 2 \mathrm{H}_{2} \mathrm{O}\right)$, rutherfordine 
$\left(\mathrm{UO}_{2} \mathrm{CO}_{3}\right)$, tyuyamunite $\left[\mathrm{Ca}\left(\mathrm{UO}_{2}\right)_{2}\left(\mathrm{VO}_{4}\right)_{2} \cdot 5-8 \mathrm{H}_{2} \mathrm{O}\right]$, autunite $\left[\mathrm{Ca}\left(\mathrm{UO}_{2}\right)_{2}\left(\mathrm{PO}_{4}\right)_{2} \cdot 10-12 \mathrm{H}_{2} \mathrm{O}\right]$, and potassium autunite $\left[\mathrm{K}_{2}\left(\mathrm{UO}_{2}\right)_{2}\left(\mathrm{PO}_{4}\right)_{2} \cdot 10-12 \mathrm{H}_{2} \mathrm{O}\right]$ (Langmuir 1997).

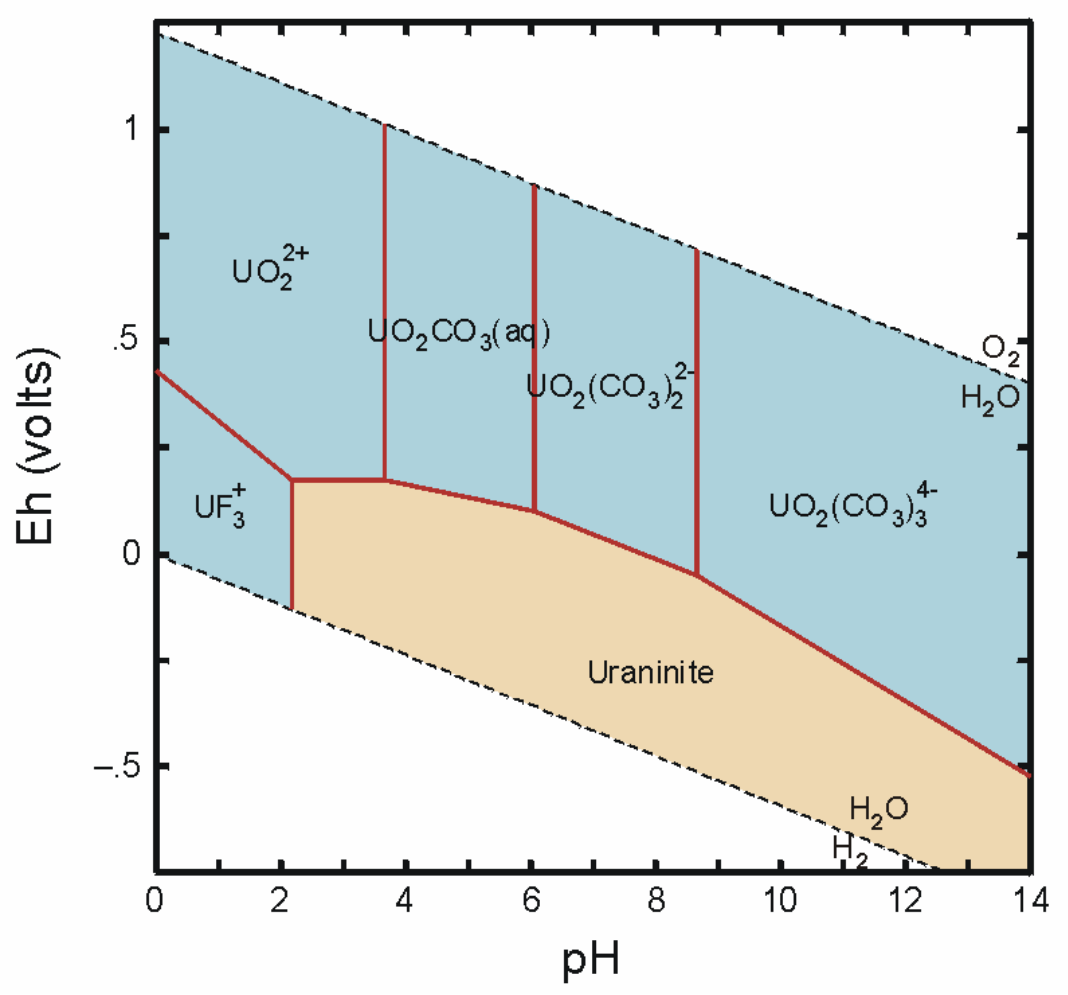

Figure 2.14. Diagram Showing Eh-pH Region (tan colored) that Calculates to be Oversaturated with Respect to the Solubility of Uraninite $\left(\mathrm{UO}_{2}\right)$ (diagram was calculated at a total concentration of $1 \times 10^{-8} \mathrm{~mol} / \mathrm{L}$ dissolved uranium at $25^{\circ} \mathrm{C}$ )

Given the omnipresence of carbonate in natural systems and the formation of strong aqueous $\mathrm{U}(\mathrm{VI})$ carbonate complexes, adsorption instead of solubility will likely control the concentration of U(VI) under oxidizing conditions at dilute concentrations of dissolved uranium away from local sources of uranium contamination. An extensive review of published uranium adsorption studies is given in EPA (1999b). Uranium(VI) adsorbs onto a variety of minerals and related phases, including clays (e.g., Ames et al. 1982; Chisholm-Brause et al. 1994), oxides and silicates (e.g., Hsi and Langmuir 1985; Waite et al. 1994), and natural organic material (e.g., Borovec et al. 1979; Shanbhag and Choppin 1981; Read et al. 1993). Important environmental parameters affecting uranium adsorption include redox conditions, $\mathrm{pH}$, and concentrations of complexing ligands, such as dissolved carbonate, ionic strength, and mineralogy.

As with the adsorption of most dissolved metals, aqueous $\mathrm{pH}$ has a significant effect on $\mathrm{U}(\mathrm{VI})$ adsorption due to the consequence of $\mathrm{pH}$ on $\mathrm{U}(\mathrm{VI})$ aqueous speciation and the number of exchange sites on variable charged surfaces of solids such as iron-, aluminum-oxides, and natural organic matter. Depending on the adsorbent, the measured adsorption of U(VI) by soils and single-mineral phases in carbonate-containing aqueous solutions is low at $\mathrm{pH}$ values less than 3 , 
increases rapidly with increasing $\mathrm{pH}$ from $\mathrm{pH} 3$ to 5 , reaches a maximum in adsorption in the $\mathrm{pH}$ range from $\mathrm{pH} 5$ to $\mathrm{pH} 7$ to 8 , and then decreases with increasing $\mathrm{pH}$ at $\mathrm{pH}$ values greater than 7 to 8, dependent on adsorbent (see Figure J.4 in EPA 1999b and references cited therein). The observed increase in $\mathrm{U}(\mathrm{VI})$ adsorption onto sediments from acidic to near-neutral $\mathrm{pH}$ values is due to the dominant $\mathrm{U}(\mathrm{VI})$ aqueous species being cationic and neutral over this $\mathrm{pH}$ range (see Figure 2.13). However, the subsequent decrease in $\mathrm{U}(\mathrm{VI})$ adsorption with increasing basic $\mathrm{pH}$ values results from the dominant $\mathrm{U}(\mathrm{VI})$ aqueous species being anionic $\mathrm{U}(\mathrm{VI})$ carbonate complexes. In the absence of dissolved carbonate, uranium sorption to iron oxide and clay minerals has been shown to be extensive and remain at a maximum at $\mathrm{pH}$ values near and above neutral pH (Kent et al. 1988; Hsi and Langmuir 1985; Ames et al. 1982). However, in the presence of carbonate and organic complexants, $\mathrm{U}(\mathrm{VI})$ adsorption has been shown to be substantially reduced or inhibited. Even differences in partial pressures of $\mathrm{CO}_{2}$ have a major effect on uranium adsorption at neutral $\mathrm{pH}$ conditions. Waite et al. (1994), for example, show that the percent of $\mathrm{U}(\mathrm{VI})$ adsorbed onto ferrihydrite decreases from approximately $97 \%$ to $38 \%$ when $\mathrm{CO}_{2}$ is increased from ambient $(0.03 \%)$ to elevated $(1 \%)$ partial pressures.

Naturally occurring organic matter in soils is also important in the adsorption of uranium. Several mechanisms have been proposed for $\mathrm{U}(\mathrm{VI})$ adsorption by organic matter (Kaplan et al. 1995). The adsorption of uranium to humic substances may occur through ion exchange and complexation processes that result in the formation of stable U(VI) complexes involving the acidic functional groups (Idiz et al. 1986; Boggs et al. 1985; Shanbhag and Choppin 1981; Borovec et al. 1979). Alternatively, Nash et al. (1981) has suggested that organic material may act to reduce dissolved $\mathrm{U}(\mathrm{VI})$ species to $\mathrm{U}(\mathrm{IV})$.

\subsubsection{Plutonium-239,240 $\left({ }^{239,240} \mathrm{Pu}\right)$}

The geochemical behavior of plutonium in natural systems has been reviewed by EPA (1999b), Onishi et al. (1981), Ames and Rai (1978), and others. Plutonium can exist in the $+3,+4,+5$, and +6 oxidation states under most environmental conditions (Allard and Rydberg 1983). Under oxidizing conditions, $\mathrm{Pu}(\mathrm{IV}), \mathrm{Pu}(\mathrm{V})$, and $\mathrm{Pu}(\mathrm{VI})$ are common, whereas $\mathrm{Pu}(\mathrm{III})$ and $\mathrm{Pu}(\mathrm{IV})$ would exist under reducing conditions.

The dominant aqueous species of plutonium are shown as a function of Eh-pH conditions in Figure 2.15. The Eh-pH diagram was calculated using a concentration of $1 \times 10^{-8} \mathrm{~mol} / \mathrm{L}$ total dissolved plutonium and the ligand concentrations listed in Table 2.2. As indicated in Figure 2.15, $\mathrm{Pu}(\mathrm{III})$ species, such as $\mathrm{Pu}^{3+}$, would be dominant up to $\mathrm{pH}$ values of approximately 8.5 under reducing conditions. The $\mathrm{Pu}(\mathrm{IV})$ species $\mathrm{Pu}(\mathrm{OH})_{4}{ }^{\circ}$ (aq) is predicted to have a large stability range extending above near neutral $\mathrm{pH}$ values at moderately oxidizing conditions to $\mathrm{pH}$ values greater than 8 under reducing conditions. Plutonium can exist in $+4,+5$, and +6 oxidation states under oxidizing conditions (Keeney-Kennicutt and Morse 1985) as shown in Figure 2.15. However, a number of investigators believe that $\mathrm{Pu}(\mathrm{V})$ is the dominant oxidation state of plutonium under oxidizing conditions (Nelson and Orlandini 1979; Aston 1980; Bondietti and Trabalka 1980, Rai et al. 1980b). 


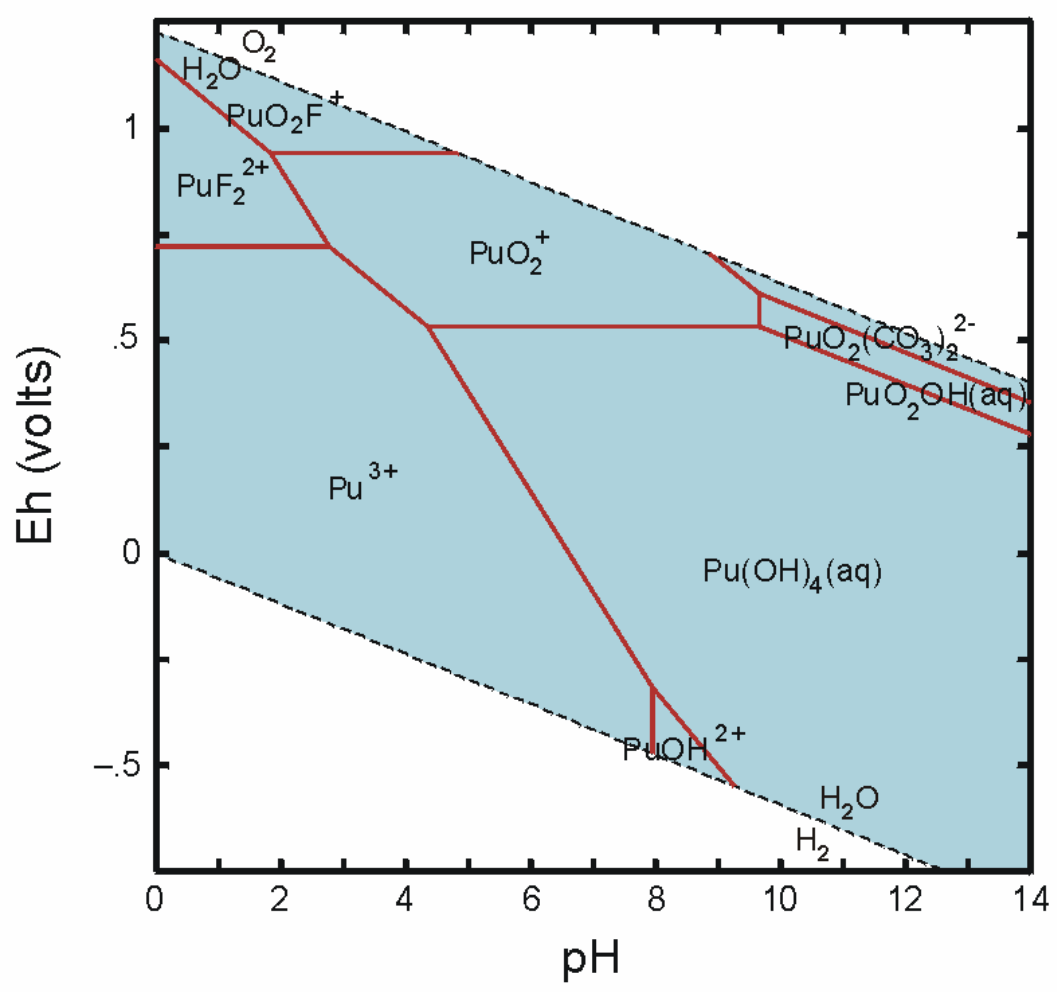

Figure 2.15. Eh-pH Diagram Showing Dominant Aqueous Species of Plutonium (diagram was calculated at a total concentration of $1 \times 10^{-8} \mathrm{~mol} / \mathrm{L}$ dissolved plutonium at $25^{\circ} \mathrm{C}$ )

Dissolved plutonium can form stable complexes with a variety of inorganic and organic ligands (Cleveland 1979). Plutonium is expected to form stronger complexes with dissolved carbonate, sulfate, phosphate, and fluoride, relative to those with ligands such as chloride and nitrate. Plutonium can also form strong mixed hydroxy-carbonate ligand complexes [e.g., $\mathrm{Pu}(\mathrm{OH})_{2}\left(\mathrm{CO}_{3}\right)_{2}{ }^{2-}$ ] (Yamaguchi et al. 1994; Tait et al. 1995). Dissolved plutonium may also form complexes with dissolved organic matter, such as fulvic and humic material. The nature of these complexes and their stability constants have not been fully characterized, but the formation of these humic complexes may dominate the aqueous speciation of plutonium in aqueous systems at $\mathrm{pH}$ values less than about 6 (Allard and Rydberg 1983).

Several studies show that plutonium associated with soils and particulate organic material is present in the +4 oxidation state (Nelson and Lovett 1980; Silver 1983; Nelson et al. 1987). Laboratory studies conducted by Rai et al. (1980a), Delegard (1987), and Yamaguchi et al. (1994) indicate that a freshly precipitated amorphous $\mathrm{PuO}_{2} \cdot \mathrm{xH}_{2} \mathrm{O}$ phase controls the equilibrium solubility of plutonium. Under oxidizing conditions, the precipitation of amorphous $\mathrm{PuO}_{2} \cdot \mathrm{xH}_{2} \mathrm{O}$ may control the maximum concentrations of dissolved plutonium at approximately $10^{-8} \mathrm{~mol} / \mathrm{L}$ or less in soils. Figure 2.16 shows the Eh-pH region (tan-colored area) in which $\mathrm{PuO}_{2}$ calculates to be oversaturated for a total concentration of $1 \times 10^{-8} \mathrm{~mol} / \mathrm{L}$ dissolved plutonium based on the available thermodynamic data and the ligand concentrations listed in Table 2.2. 


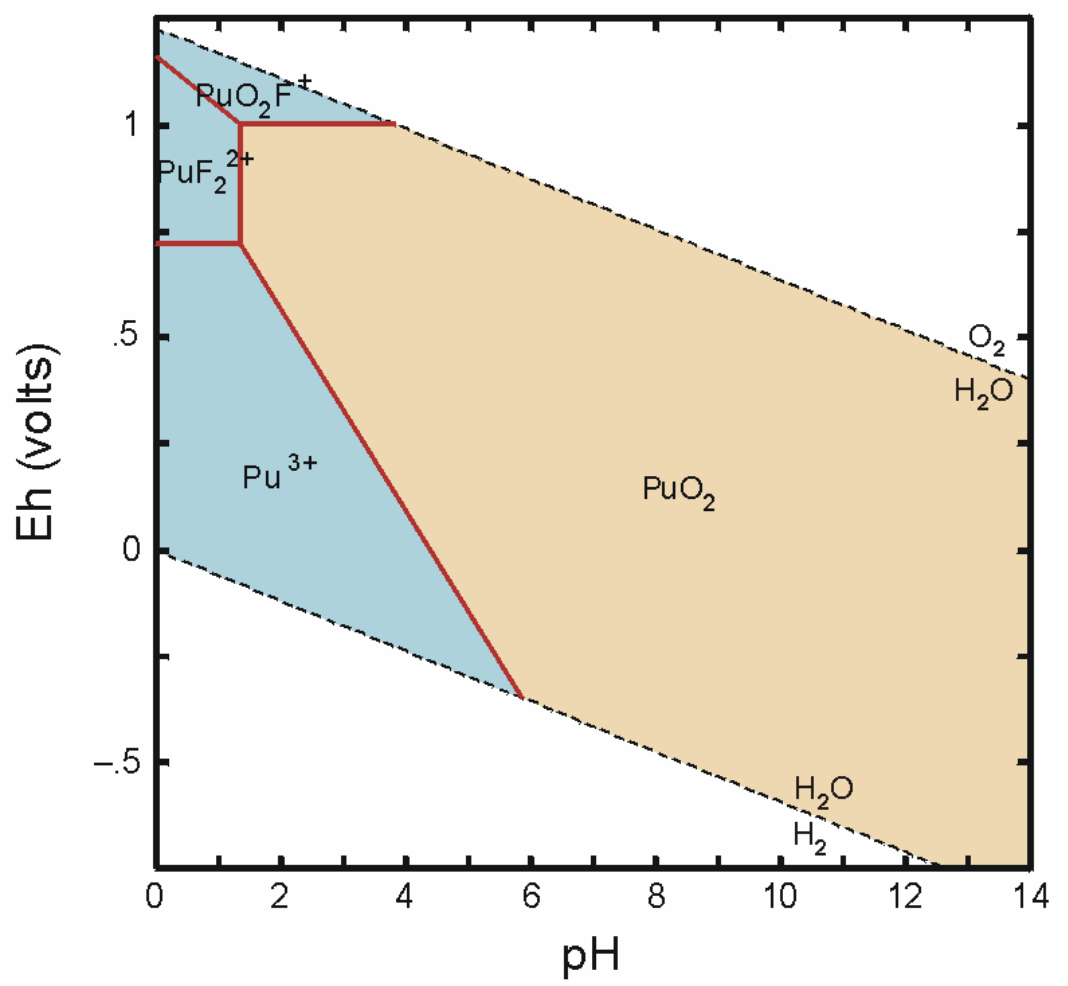

Figure 2.16. Diagram Showing Eh-pH Region (tan colored) that Calculates to be Oversaturated with Respect to the Solubility of $\mathrm{PuO}_{2}$ (diagram was calculated at a total concentration of $1 \times 10^{-8} \mathrm{~mol} / \mathrm{L}$ dissolved plutonium at $25^{\circ} \mathrm{C}$ )

Dissolved plutonium in the environment is typically present at less than $10^{-15} \mathrm{~mol} / \mathrm{L}$ (EPA 1999b). This indicates that adsorption may be the main process affecting the retardation of plutonium in soils. Plutonium is known to adsorb strongly to a variety of soil components, including clays, oxides, hydroxides, oxyhydroxides, aluminosilicates and organic matter (see review in EPA 1999b and references therein). Several studies show that plutonium present in the higher +5 and +6 oxidation states may be reduced to the +4 state by adsorption onto iron-oxide surfaces containing $\mathrm{Fe}(\mathrm{II})$ (EPA 1999b). The $\mathrm{K}_{\mathrm{d}}$ values for plutonium can range typically over several orders of magnitude, depending on the properties of the substrate, $\mathrm{pH}$, and the composition of solution (Baes and Sharp 1983; Coughtrey et al. 1985; Thibault et al. 1990). The $\mathrm{K}_{\mathrm{d}}$ values listed for plutonium in the compilation by Thibault et al. (1990) range from 27 to $190,000 \mathrm{~mL} / \mathrm{g}$. However, EPA (1999a) cautions that measurements resulting in very large $\mathrm{K}_{\mathrm{d}}$ values may have been compromised by precipitation processes.

Adsorption studies indicate that the presence of increasing concentrations of ligands typically decrease plutonium adsorption (EPA 1999b). If no complexing ligands are present, the adsorption of plutonium in general increases with increasing $\mathrm{pH}$ from about $\mathrm{pH} 5$ to 9 . At $\mathrm{pH}$ values of 7 and greater, concentrations of dissolved carbonate and hydroxide will decrease the adsorption of plutonium and increase its mobility in soils as a result of the formation of strong mixed ligand complexes with plutonium (EPA 1999b). The laboratory study by Sanchez et al. (1985) showed that increasing carbonate concentrations decreased the adsorption of $\mathrm{Pu}(\mathrm{IV})$ and 
$\mathrm{Pu}(\mathrm{V})$ on the surface of goethite $[\alpha-\mathrm{FeO}(\mathrm{OH})]$. At low $\mathrm{pH}$ conditions in the presence of high concentrations of dissolved organic carbon, plutonium-organic complexes may control the adsorption and mobility of plutonium in soils (EPA 1999a).

\subsubsection{Neptunium-237 $\left({ }^{237} \mathrm{~Np}\right)$}

The environmental chemistry and mobility of neptunium in surface water, groundwater, and geologic environments has been reviewed by others, such as Silva and Nitsche (1995), Tanaka et al. (1992), Lieser and Mühlenweg (1988), Coughtrey et al. (1984), Thompson (1982), Onishi et al. (1981), and Ames and Rai (1978). Neptunium may exist in the $+3,+4,+5,+6$, and +7 valence states, but only the $+4,+5$, and possibly +6 states are relevant to natural environments. Neptunium(VI) is stable only in highly oxidizing solutions and is therefore not important under most environmental conditions. Neptunium(V) exists in oxidizing environmental systems and is considered relatively mobile because $\mathrm{Np}(\mathrm{V})$ aqueous species do not readily adsorb to soil, and $\mathrm{Np}(\mathrm{V})$ solids are quite soluble. Neptunium(IV) occurs under reducing conditions and is less mobile than $\mathrm{Np}(\mathrm{V})$. Like $\mathrm{U}(\mathrm{IV})$ and $\mathrm{Pu}(\mathrm{IV}), \mathrm{Np}(\mathrm{IV})$ may form sparingly soluble oxide and hydroxide solids that limit the mobility of $\mathrm{Np}(\mathrm{IV})$ under reducing conditions.

The reduction of redox-sensitive elements, such as neptunium, by abiotic and biotic processes has been the subject of considerable interest because these reactions have a significant effect on the environmental mobility of redox-sensitive elements. For example, redox-sensitive elements can be immobilized by surface-mediated, heterogeneous reduction/sorption reactions on $\mathrm{Fe}(\mathrm{II})$-containing oxide and silicate minerals that exist as coatings on soil particles and/or primary constituents of soils (see review in White 1990). The heterogeneous electrochemical reactions occur by electron transfer reactions by which the $\mathrm{Fe}(\mathrm{II})$ is oxidized to $\mathrm{Fe}(\mathrm{III})$, and the redox-sensitive contaminant, is reduced to a lower valence state, such as reduction of $\mathrm{Np}(\mathrm{V})$ to $\mathrm{Np}(\mathrm{IV})$. Surface-mediated, heterogeneous reduction/sorption of $\mathrm{Np}(\mathrm{V})$ has been studied by Hakanen and Lindberg (1991), Susak et al. (1983), Meyer et al. (1984), and Bondietti and Francis (1979).

The reduction of $\mathrm{Np}(\mathrm{V})$ to $\mathrm{Np}(\mathrm{IV})$ by biotic processes has also been demonstrated. Lloyd et al. (2000a) conducted a biochemical study of the reduction of $\mathrm{Np}(\mathrm{V})$. Their experiments demonstrated that Shewanella putrefaciens reduced $\mathrm{Np}(\mathrm{V})$ to a lower valence state, possibly $\mathrm{Np}(\mathrm{IV})$. However, this reduction process was not sufficient to remove neptunium from solution. Lloyd et al. (2000a) were able to remove ${ }^{237} \mathrm{~Np}$ and its daughter product ${ }^{233} \mathrm{~Pa}$ from solution by bioprecipitation using a combination of the two organisms $S$. putrefaciens and Citrobacter sp. The bioprecipitation resulted from bioreduction to $\mathrm{Np}(\mathrm{IV})$ by $S$. putrefaciens in concert with phosphate liberation by the Citrobacter $s p$ from the glycerol 2-phosphate solution.

The thermodynamic data for neptunium aqueous species and solids are limited and not well known relative to other radionuclides. Lemire et al. (2001) have published an extensive, detailed review of the chemical thermodynamics of neptunium. However, as noted in Section 2.2, the thermodynamic values compiled in their review were not included in the thermodynamic database used to calculate the Eh-pH diagrams. Figure 2.17 is an Eh-pH diagram that shows the dominant aqueous species for dissolved neptunium. The diagram was calculated at $25^{\circ} \mathrm{C}$ using a concentration of $1 \times 10^{-8} \mathrm{~mol} / \mathrm{L}$ total dissolved neptunium and the ligand concentrations listed in 
Table 2.2. Under oxidizing conditions, the neptunyl ion, $\mathrm{NpO}_{2}{ }^{+}$, calculates to be the dominant $\mathrm{Np}(\mathrm{V})$ aqueous species at $\mathrm{pH}$ values less than $\mathrm{pH}$ 8.5. At higher $\mathrm{pH}$ values, anionic $\mathrm{Np}(\mathrm{V})$ carbonate complexes, such as $\mathrm{NpO}_{2} \mathrm{CO}_{3}{ }^{-}$and $\mathrm{NpO}_{2}\left(\mathrm{CO}_{3}\right)_{3}{ }^{5-}$, are predicted to be the aqueous complexes under oxidizing conditions. Under reducing conditions, the hydroxyl complex $\mathrm{Np}(\mathrm{OH})_{4}{ }^{\circ}$ (aq) is the dominant $\mathrm{Np}(\mathrm{IV})$ aqueous complex at $\mathrm{pH}$ values greater than 4 (Figure 2.17). Based the available thermodynamic data and ligand concentrations used for these speciation calculations, the species $\mathrm{NpF}_{2}{ }^{2+}$ may be the important $\mathrm{Np}(\mathrm{IV})$ aqueous complex at very acidic $\mathrm{pH}$ values under moderately oxidizing to reducing conditions.

Moulin et al. (1992) reviews the aqueous speciation of neptunium in the presence of humic substances in soils and natural waters. The complexation and reduction of $\mathrm{Np}(\mathrm{V})$ with humic substances has also been investigated by various laboratories with different experimental methods (Artinger et al. 2000; Sakamoto et al. 2000; Zeh et al. 1999; Marquardt and Kim 1996, 1998; Rao and Choppin 1995; Choppin 1992; Kim and Sekine 1991). The results of these studies suggest that humate complexation of $\mathrm{Np}(\mathrm{V})$ may play an important role in systems with relatively high humic acid concentrations. Reduction of $\mathrm{Np}(\mathrm{V})$ to $\mathrm{Np}(\mathrm{IV})$ by interaction with humic acid may also be another important reaction to consider relative to the environmental behavior of neptunium.

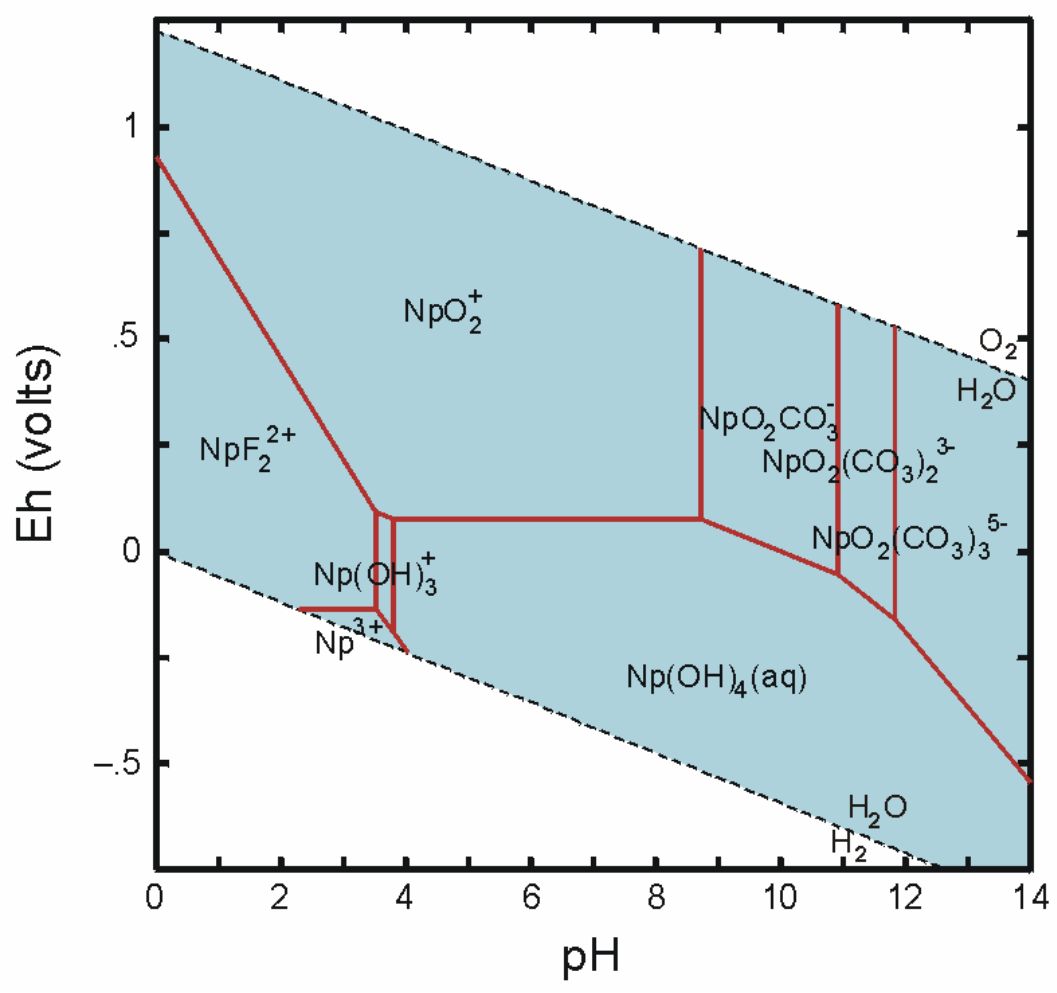

Figure 2.17. Eh-pH Diagram Showing Dominant Aqueous Species of Neptunium (diagram was calculated at a total concentration of $1 \times 10^{-8} \mathrm{~mol} / \mathrm{L}$ dissolved neptunium at $\left.25^{\circ} \mathrm{C}\right)$ 
The solubility of $\mathrm{Np}(\mathrm{V})$ has been studied extensively for the purpose of estimating the maximum solubility concentrations of dissolved neptunium that might be released under oxidizing conditions from a geologic repository for HLW with subsequent migration in groundwater systems (e.g., Novak and Roberts 1995; Neck et al. 1994; Lemire 1984). If the concentrations of dissolved $\mathrm{Np}(\mathrm{V})$ are sufficiently high, the solubility of $\mathrm{Np}(\mathrm{V})$ may be controlled by hydroxide or carbonate solids. In carbonate-free aqueous solutions with $\mathrm{OH}^{-}$as the only complexing ligand, the maximum concentration of dissolved $\mathrm{Np}(\mathrm{V})$ is likely determined by the solubility product of solids, such as $\mathrm{Np}_{2} \mathrm{O}_{5} \cdot \mathrm{xH}_{2} \mathrm{O}$ (Efurd et al. 1998) or solid $\mathrm{NpO}_{2} \mathrm{OH}$ (Al Mahamid et al. 1998, Roberts et al. 1996). In carbonate-rich solutions, a variety of solids, such as hydrated $\mathrm{NaNpO}_{2} \mathrm{CO}_{3}\left(\mathrm{Neck}\right.$ et al. 1994, Lemire et al. 1993), $\mathrm{Na}_{3} \mathrm{NpO}_{2}\left(\mathrm{CO}_{3}\right)_{2}(\mathrm{Al}$ Mahamid et al. 1998, Neck et al. 1994, Lemire et al. 1993), and $\mathrm{KNpO}_{2} \mathrm{CO}_{3}$ (Al Mahamid et al. 1998, Lemire et al. 1993), have been studied as possible solubility controls for the maximum concentrations of dissolved $\mathrm{Np}(\mathrm{V})$ under oxidizing conditions.

Under reducing conditions, $\mathrm{Np}(\mathrm{IV})$ is not considered very mobile because it forms sparingly soluble oxide and hydroxide solids. Solids, such as Np(IV) hydrous oxide (Nakayama et al. 1996; Rai and Ryan 1985), amorphous $\mathrm{NpO}_{2} \times \mathrm{xH} 2 \mathrm{O}$ (Rai et al. 1987), and amorphous $\mathrm{NpO}_{2}$ (Rai et al. 1999) have been studied as possible solubility controls for $\mathrm{Np}(\mathrm{IV})$. In the study by Itagaki et al. (1991), the precipitation of amorphous $\mathrm{NpO}_{2} \cdot \mathrm{xH}_{2} \mathrm{O}$ and its colloids were found to be important to the mobility of neptunium in environmental systems.

Figure 2.18 shows that solid $\mathrm{NpO}_{2}$ is oversaturated over a large range of Eh-pH conditions for a system containing $1 \times 10^{-8} \mathrm{~mol} / \mathrm{L}$ total dissolved neptunium. In the Eh-pH region defined by the tan-colored area in Figure 2.18, $\mathrm{NpO}_{2}$ calculates to be oversaturated based on the available thermodynamic data and may precipitate at these Eh-pH conditions to limit the maximum concentration of dissolved technetium in soil.

An extensive review of neptunium adsorption studies on soils, pure minerals, oxide phases, and crushed rock materials is presented in EPA (2003). Coughtrey et al. (1984) review sorption studies published before 1984. Neptunium(V) species adsorb to some extent to iron oxide and clay minerals, but do not adsorb to a major degree on most common minerals. Therefore, dissolved $\mathrm{Np}(\mathrm{V})$ is considered to be relatively mobile in soil systems. Because $\mathrm{NpO}_{2}{ }^{+}$does not compete favorably with dissolved $\mathrm{Ca}^{2+}$ and other divalent ions for adsorption sites on soils, the $\mathrm{K}_{\mathrm{d}}$ values for $\mathrm{Np}(\mathrm{V})$ are relatively low (Kaplan and Serne 2000). The results of experimental studies indicate that the adsorption of $\mathrm{Np}(\mathrm{V})$ has a strong dependence on $\mathrm{pH}$, especially for iron oxides (Kohler et al. 1999; Girvin et al. 1991; Allard 1984). The adsorption of Np(V) has a strong dependence on $\mathrm{pH}$. Typically, the sorption of $\mathrm{Np}(\mathrm{V})$ on minerals is negligible at $\mathrm{pH}$ values less than $\mathrm{pH}$, and increases rapidly at $\mathrm{pH}$ values between 5 to 7 . This $\mathrm{pH}$-dependency is expected for ions that are present in solution primarily as cations, such as $\mathrm{NpO}_{2}{ }^{+}$(EPA 1999a). In carbonate-containing solutions, the adsorption of $\mathrm{Np}(\mathrm{V})$ on iron oxides has been observed to decrease at $\mathrm{pH}$ values greater than 7 to 9 in response to the formation of aqueous $\mathrm{Np}(\mathrm{VI})$ carbonate complexes (Kohler et al. 1999). This latter behavior is analogous to that observed for the adsorption of $\mathrm{U}(\mathrm{VI})$ in carbonate-solutions at alkaline $\mathrm{pH}$ values (see Section 2.2.2.8). 


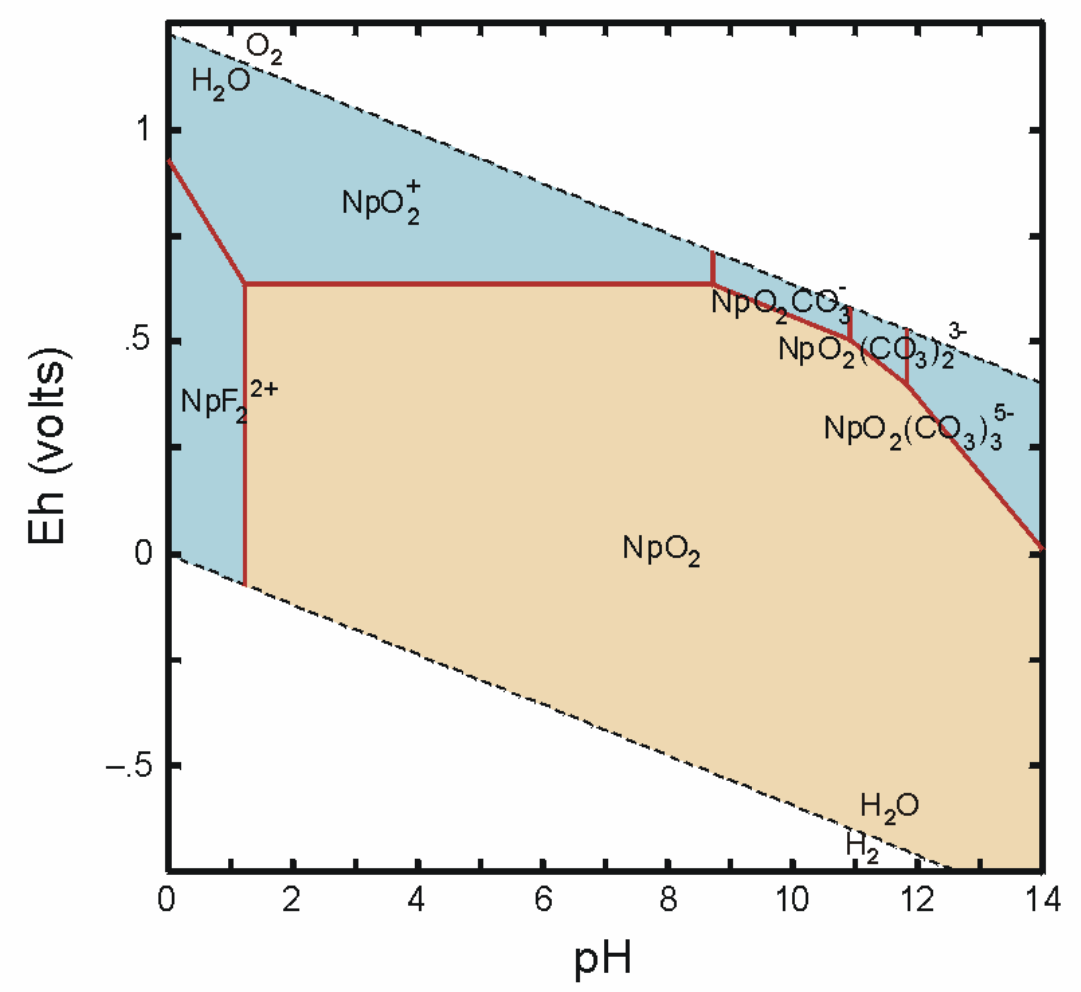

Figure 2.18. Diagram Showing Eh-pH Region (Tan Colored) that Calculates to be Oversaturated with Respect to the Solubility of Neptunium Solids (diagram was calculated at a total concentration of $1 \times 10^{-8} \mathrm{~mol} / \mathrm{L}$ dissolved neptunium at $25^{\circ} \mathrm{C}$ )

\subsubsection{Americium-241 ( $\left.{ }^{241} \mathrm{Am}\right)$}

The environmental behavior of americium has been reviewed by Silva and Nitsche (1995), Coughtrey et al. (1984), Onishi et al. (1981), Ames and Rai (1978), and others. Moulin et al. $(1988,1992)$ review the aqueous speciation of Am(III) in natural waters and in the presence of humic substances in natural waters, respectively. Silva et al. (1995) have published an extensive, detailed critical review of the chemical thermodynamics of americium aqueous species and solids. Americium can exist in the $+3,+4,+5$, and +6 oxidation states. However, Am(III) is the most stable and important oxidation state in environmental systems. The higher oxidation states are strong oxidizing agents and stable only in systems containing no oxidizable compounds (Ames and Rai 1978).

Figure 2.19 is an Eh-pH diagram that shows the dominant aqueous species of americium. The diagram was calculated at $25^{\circ} \mathrm{C}$ using a total concentration of $1 \times 10^{-8} \mathrm{~mol} / \mathrm{L}$ dissolved americium and dissolved ligand concentrations given in Table 2.2. Americium is present in the +3 oxidation state in all of the dominant species predicted to be stable for the Eh-pH region of environmental interest. The uncomplexed ion $\mathrm{Am}^{3+}$ is the dominant aqueous species at moderately to highly acidic conditions. At near neutral to alkaline $\mathrm{pH}$ conditions, Am(III) carbonate and hydroxyl complexes will dominate the aqueous speciation of Am(III) (Figure 2.19). Aqueous complexes, such as $\mathrm{Am}\left(\mathrm{CO}_{3}\right)_{3}{ }^{3-}$, will be increasingly important with increasing 
concentrations of dissolved carbonate at alkaline $\mathrm{pH}$ conditions. In soils, studies indicate that Am(III) may also form strong complexes with humic substances (Moulin et al. 1992).

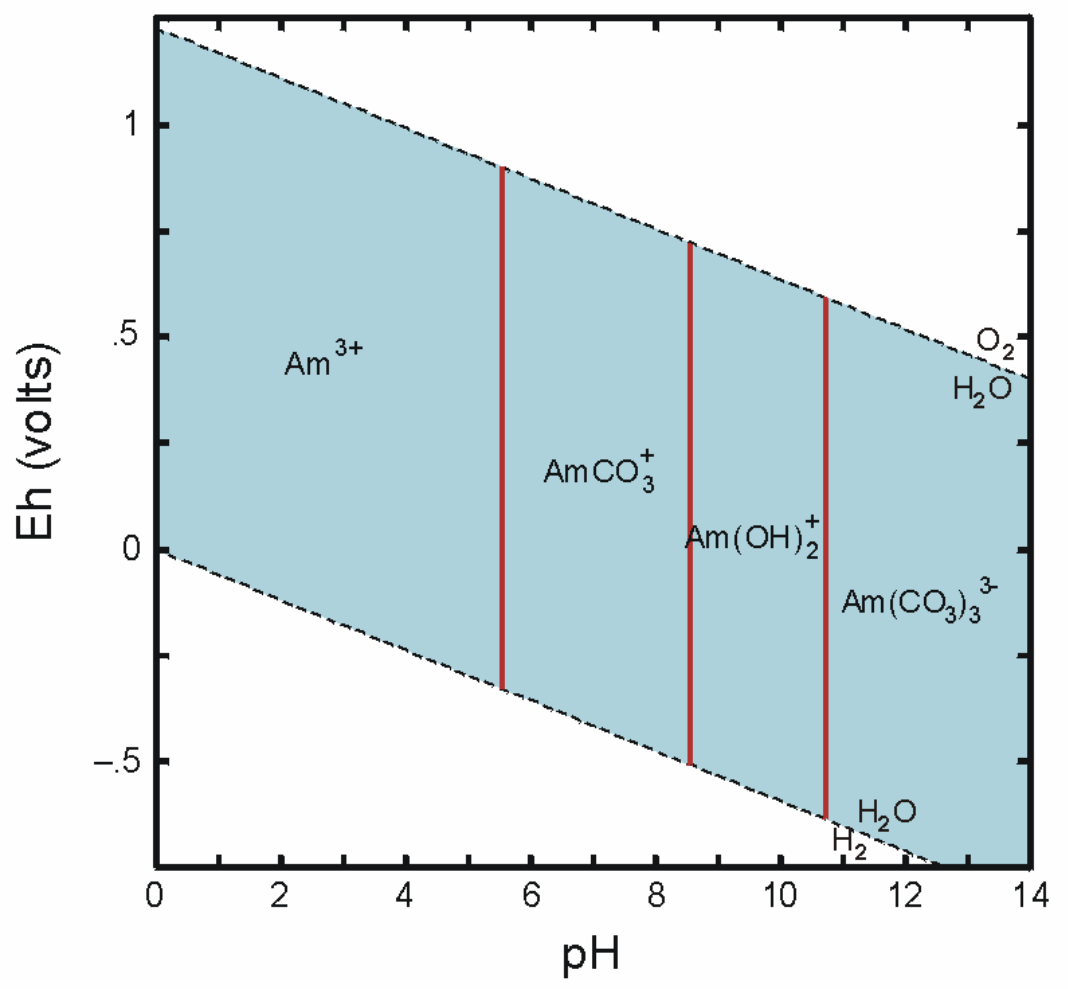

Figure 2.19. Eh-pH Diagram Showing Dominant Aqueous Species of Americium (diagram was calculated at a total concentration of $1 \times 10^{-8} \mathrm{~mol} / \mathrm{L}$ dissolved americium at $25^{\circ} \mathrm{C}$ )

Concentrations of dissolved Am(III) in soil environments may be controlled by the precipitation of hydroxide or carbonate solids in some systems (e.g., Felmy et al. 1990; Vitorge 1992; Silva 1984). In the Eh-pH region defined by the tan-colored area in Figure 2.20, the solid $\mathrm{Am}(\mathrm{OH})_{3}$ calculates to be oversaturated based on the available thermodynamic data and the americium and ligand concentrations used for Figure 2.19. Under these Eh-pH conditions (tan-colored area in Figure 2.20), $\mathrm{Am}(\mathrm{OH})_{3}$ may precipitate to limit the maximum concentration of dissolved Am(III) in soil. With increasing $\mathrm{pH}$ and dissolved carbonate concentrations, solids such as $\mathrm{AmOHCO}_{3}$ and $\mathrm{Am}_{2}\left(\mathrm{CO}_{3}\right)_{3}$ will be the likely solubility controls for dissolved Am(III). Vitorge (1992) used thermodynamic calculations to predict the stability domains of these Am(III) solids as a function of $\mathrm{pH}$ and dissolved carbonate.

Most sorption studies indicate that Am(III) readily sorbs to soils, pure minerals, and crushed rock materials and exhibits high $\mathrm{K}_{\mathrm{d}}$ values that are often in the range of 1,000 to greater than $100,000 \mathrm{~mL} / \mathrm{g}$. Americium(III) is therefore considered one of the most immobile actinide elements in the environment. An extensive review of Am(III) sorption studies is presented in EPA (2003). Americium(III) adsorption studies published before 1984 have been reviewed by Coughtrey et al. (1984), Onishi et al. (1981), and Ames and Rai (1978). As discussed above, the concentrations of dissolved Am(III) may be controlled in some soil systems by precipitation of 
hydroxide or carbonate solids. Therefore, some sorption measurements resulting in very high $\mathrm{K}_{\mathrm{d}}$ values may have been affected by the precipitation of an Am(III) solid (EPA 1999a).

The adsorption of $\mathrm{Am}(\mathrm{III})$ is strongly $\mathrm{pH}$ dependent and increases with increasing $\mathrm{pH}$ with peak adsorption occurring between $\mathrm{pH}$ values of 5 and 6 (EPA 2003). This observed $\mathrm{pH}$ dependence is expected because the dominant aqueous species of $\mathrm{Am}$ (III) in the $\mathrm{pH}$ range of natural waters are primarily $\mathrm{Am}^{3+}$ and cationic carbonate and hydroxyl complexes at acidic and basic $\mathrm{pH}$ values, respectively (Figure 2.19). Americium(III) is more mobile at low to moderate $\mathrm{pH}$ values where the net surface charge on minerals becomes more positive and in high ionic strength solutions. Adsorption of Am(III) might decrease in the $\mathrm{pH}$ values greater than 10 due to the dominance of the anionic complex $\mathrm{Am}\left(\mathrm{CO}_{3}\right)_{3}{ }^{3-}$ (Figure 2.19).

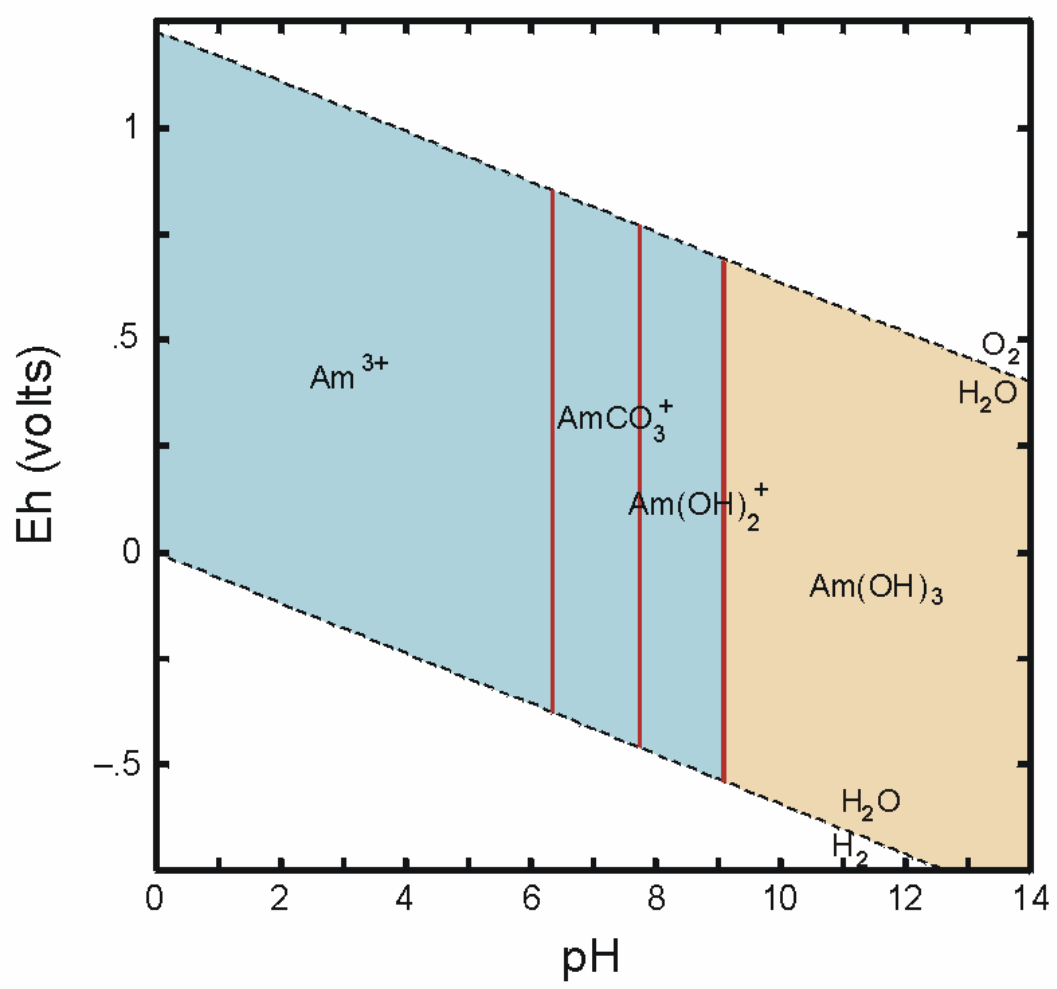

Figure 2.20. Diagram Showing Eh-pH Region (tan colored) that Calculates to be Oversaturated with Respect to the Solubility of Americium Solids (diagram was calculated at a total concentration of $1 \times 10^{-8} \mathrm{~mol} / \mathrm{L}$ dissolved americium at $\left.25^{\circ} \mathrm{C}\right)$

However, the tendency of Am(III) to strongly sorb to soil particles suggests that there is potential for colloid-facilitated transport of Am(III). For example, studies by Sheppard et al. (1979), Penrose et al. (1990), and Kaplan et al. (1994) have shown colloid-facilitated transport of Am(III) in certain soil systems. Sheppard et al. (1979) used batch-equilibration experiments to study the sorption of Am(III) and Cm(III) to colloidal-size soil particles that are potentially diffusible in soil/water systems. The experiments were conducted with distilled water and 14 soils from Muscatine, Illinois; Hanford, Washington; Barnwell, South Carolina; Idaho Falls, Idaho; and Paradise and Placerville, California. Centrifugation measurements indicated that 
much of the Am(III) was retained by the colloidal-size soil particles. Sheppard et al. (1979) suggested that colloids of clay and humic acids are potentially important processes for the transport of actinides in soil/water systems. Laboratory studies by Penrose et al. (1990) predicted that the movement of americium and plutonium would be limited to less than a few meters through a shallow aquifer within the site of the Los Alamos National Laboratory (LANL), which is in a semiarid region. However, both actinides were detected in monitoring wells as far as $3,390 \mathrm{~m}(11,122 \mathrm{ft})$ down gradient from the point source and were determined to be primarily associated with colloids 0.025 to $0.45 \mathrm{~m}(0.082$ to $1.5 \mathrm{ft})$ in diameter. Similarly, the results of laboratory measurements using site-specific soils and a two-phase solute transport code indicated that americium, curium, plutonium, and uranium would migrate less than $10 \mathrm{~m}(32.8 \mathrm{ft})$ in the F-Area of the Savannah River Site (Kaplan et al. 1994). The contaminants, however, were found associated with groundwater colloids 1,200 $\mathrm{m}(3,937 \mathrm{ft})$ away from the point source.

\subsubsection{Curium-242 $\left({ }^{242} \mathrm{Cm}\right)$}

The environmental behavior of curium has been reviewed by Silva and Nitsche (1995), Coughtrey et al. (1984), Onishi et al. (1981), Ames and Rai (1978), and others. Curium can exist in the +3 and +4 oxidation states, but the +3 state is the dominant oxidation state in natural waters. Curium(IV) is not stable in solutions because of self-radiation reactions (Onishi et al. 1981). A very limited number of laboratory and field studies exist for the aqueous speciation, solubility, and sorption behavior of Cm(III). Because the electronic structures of the $\mathrm{Cm}$ (III), Am(III), and trivalent lanthanides (rare-earth elements [REE]) are similar, the environmental behavior, i.e., aqueous speciation, solubility, and sorption, of $\mathrm{Cm}$ (III) is expected to be very similar to that of Am(III) (see Section 2.2.2.11) and trivalent lanthanide elements, such as $\mathrm{Eu}(\mathrm{III})$. This analogy is well established; for example, see Choppin (1989).

Curium(III) should form complexes with inorganic ligands present in natural waters. However, the thermodynamic data for curium aqueous species are limited and not well established. By analogy to the aqueous speciation calculated for Am(III) (see Section 2.2.2.11), the aqueous speciation of $\mathrm{Cm}$ (III) is likely dominated by the uncomplexed ion $\mathrm{Cm}^{3+}$ at acidic to near-neutral $\mathrm{pH}$ conditions and by $\mathrm{Cm}$ (III) carbonate and hydroxyl complexes at neutral to high $\mathrm{pH}$ conditions. This analogy is consistent with the results of Wimmer et al. (1992), who determined the equilibrium constants for several $\mathrm{Cm}$ (III) hydrolytic and carbonate aqueous complexes by time-resolved laser-induced fluorescence spectroscopy. Based on the constants in Wimmer et al. (1992), $\mathrm{Cm}^{3+}$ is predicted to be the dominant species at $\mathrm{pH}$ values less than 7 . The complexes $\mathrm{CmCO}_{3}{ }^{+}$and $\mathrm{Cm}(\mathrm{OH})_{2}{ }^{+}$dominate the aqueous speciation of $\mathrm{Cm}(\mathrm{III})$ in the $\mathrm{pH}$ range from 7 to 9 and at $\mathrm{pH}$ values greater than 9 , respectively. Other aqueous complexation studies of Cm(III) include those on aqueous complexation by dissolved carbonate (Fanghänel et al. 1998), sulfate (Paviet et al. 1996), fluoride (Aas et al. 1999), chloride (Könnecke et al. 1997), and humic substances (Hummel et al. 1999; Panak et al. 1996; Shin et al. 1995; Kim et al. 1993).

No studies pertaining to solubility controls for dissolved curium in natural environments were identified during the course of this review. By analogy to the known solubilities of Am(III) solids (see Section 2.2.2.11), the concentrations of dissolved Cm(III) in soil environments at basic $\mathrm{pH}$ values may be controlled by the precipitation of hydroxide and/or carbonate solids analogous to $\mathrm{Am}(\mathrm{OH})_{3}$ and $\mathrm{AmOHCO}_{3}$. 
There are very few experimental and field studies of the adsorption behavior and mobility of curium in environmental systems. The results of curium adsorption studies published before 1981 have been reviewed by Ames and Rai (1978) and Onishi et al. (1981). More current studies are reviewed in EPA (2003). All of the available sorption studies indicate that Cm(III) readily sorbs to minerals, crushed rock, and soil materials. Compared to other actinides, Cm(III) is considered to be immobile in soil environments and exhibits high $\mathrm{K}_{\mathrm{d}}$ values. The results of published $\mathrm{Cm}$ (III) studies indicate that $\mathrm{Cm}(\mathrm{III})$ adsorption is strongly $\mathrm{pH}$ dependent and increases with increasing $\mathrm{pH}$ with peak adsorption occurring between $\mathrm{pH}$ values of 5 and 6 . The observed $\mathrm{pH}$ dependence is expected because the dominant aqueous species of curium in the $\mathrm{pH}$ range of natural waters are primarily cations such as $\mathrm{Cm}^{3+}$ and $\mathrm{Cm}$ (III) carbonate complexes at acidic and basic $\mathrm{pH}$ values, respectively. Because the concentrations of dissolved Cm(III) may be controlled by the precipitation of hydroxide or carbonate solids in some systems, it should be noted that some sorption measurements resulting in very high $\mathrm{K}_{\mathrm{d}}$ values may have been affected by $\mathrm{Cm}(\mathrm{III})$ precipitation reactions.

As noted above, the geochemical behavior of $\mathrm{Eu}(\mathrm{III})$ has been determined to be analogous to trivalent actinides, such as $\mathrm{Cm}(\mathrm{III})$. Therefore, the following generalities made by Clark et al. (1998) regarding Eu(III) adsorption should also apply to Cm(III) and Am(III):

- $\mathrm{Eu}(\mathrm{III})$ adsorption increases with increasing $\mathrm{pH}$.

- $\mathrm{Eu}(\mathrm{III})$ adsorption is sensitive to the ionic strength at low concentrations of total Eu(III) and to calcium at higher concentrations of total europium.

- Ion exchange is an important sorption mechanism for $\mathrm{Eu}(\mathrm{III})$, especially at $\mathrm{pH}$ values less than 4.5.

- The mobility of Eu(III) in the environment increases at low to moderate $\mathrm{pH}$ values and in high-ionic-strength solutions.

As discussed in Section 2.2.2.11) relative to the environmental mobility of Am(III), the tendency of Cm(III), like Am(III), to strongly adsorb to soil particles suggests that there is potential for colloid-facilitated transport of Cm(III). The results of studies by Kaplan et al. (1994) and Sheppard et al. (1979) indicate that the mobility of Cm(III) in soils may be enhanced by its migration in colloid form.

\subsubsection{Beryllium-10 ( $\left.{ }^{10} \mathrm{Be}\right)$}

Information regarding the environmental behavior of beryllium in soils and aqueous systems is limited. The available information has been reviewed by Kaste et al. (2002), Veselý et al. (2002), and Rai et al. (1984). Beryllium is an alkaline-earth element and exists only in the +2 oxidation state in aqueous systems (Baes and Mesmer 1976). Hydroxide and fluoride are the only inorganic ligands that form strong complexes with dissolved beryllium (Baes and Mesmer 1976, Veselý et al. 2002). Veselý et al. (2002) also note that the mobility of beryllium in geochemical systems may also be enhanced by the formation of soluble organic (fulvic) acid complexes. No information was available regarding the formation of aqueous beryllium 
carbonate complexes or their potential importance to beryllium mobility under basic $\mathrm{pH}$ conditions.

Figure 2.21 is an Eh-pH diagram that shows the dominant aqueous species of beryllium calculated for a concentration of $1 \times 10^{-8} \mathrm{~mol} / \mathrm{L}$ total dissolved beryllium and the ligand concentrations listed in Table 2.2. Based on the thermodynamic data available in The Geochemist's Workbench ${ }^{\circledR}$ (Version 4.0) software package, $\mathrm{Be}^{2+}$ and $\mathrm{Be}(\mathrm{OH})_{4}{ }^{2-}$ $\left(=\mathrm{BeO}_{2}{ }^{2-}+2 \mathrm{H}_{2} \mathrm{O}\right)$ are predicted to be the dominant aqueous species for beryllium at $\mathrm{pH}$ values less and greater than $\mathrm{pH} 8$, respectively.

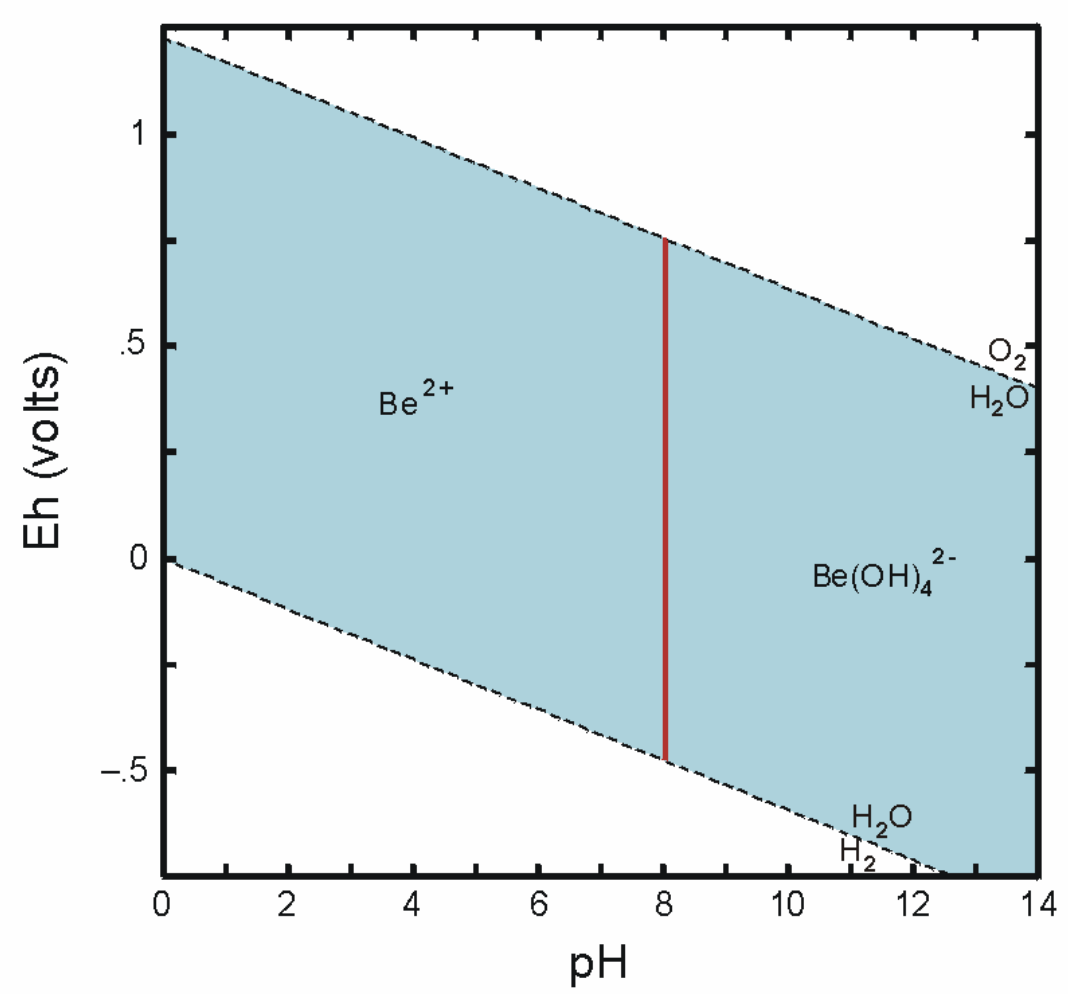

Figure 2.21. Eh-pH Diagram Showing Dominant Aqueous Species of Beryllium (diagram was calculated at a total concentration of $1 \times 10^{-8} \mathrm{~mol} / \mathrm{L}$ dissolved beryllium at $\left.25^{\circ} \mathrm{C}\right)$

The aqueous speciation shown in Figure 2.21 is inconsistent with that calculated by Rai et al. (1984). In the absence of dissolved fluoride, Rai et al. (1984) list the uncomplexed ion $\mathrm{Be}^{2+}$ as the dominant aqueous species at acidic $\mathrm{pH}$ values less than approximately 5.5. At $\mathrm{pH}$ values greater than 5.5, the dominant aqueous species are calculated to be the hydroxide complexes $\mathrm{BeOH}^{+}$from $\mathrm{pH} 5.5$ to $8.2, \mathrm{Be}(\mathrm{OH})_{2}{ }^{\circ}$ (aq) from $\mathrm{pH} 8.2$ to 9.6 , and $\mathrm{Be}(\mathrm{OH})_{3}{ }^{-}$at $\mathrm{pH}$ greater than 9.6 (Rai et al. 1984). With sufficient concentrations of dissolved fluoride, berylliumfluoride aqueous complexes may dominate the speciation of dissolved beryllium at acidic $\mathrm{pH}$ conditions. In the presence of $10^{-5} \mathrm{~mol} / \mathrm{L}$ dissolved fluoride, the calculations by Rai et al. (1984) show that $\mathrm{BeF}^{+}$is the most dominant beryllium species at $\mathrm{pH}$ values less than 5.5. Rai et al. (1984) note, however, that uncertainty exists regarding the thermodynamic values that they used 
for $\mathrm{Be}(\mathrm{OH})_{2}{ }^{\mathrm{o}}$ (aq) and the beryllium-fluoride aqueous complexes. Speciation calculations presented in Veselý et al. (2002) indicate that beryllium-fluoride complexes, such as $\mathrm{BeF}^{+}$and $\mathrm{BeF}_{2}{ }^{\circ}$ (aq), will be dominant in the $\mathrm{pH}$ range from approximately 4 to 6 , whereas the uncomplexed ion $\mathrm{Be}^{2+}$ will be the most stable aqueous species at lower $\mathrm{pH}$ values (Veselý et al. 2002).

Essentially no information was found regarding the formation of beryllium solids that could precipitate in soil and aqueous systems and control the maximum concentration of beryllium in such environments. No mention was made in any of the literature examined during this review relative to the potential importance of beryllium (co)precipitation as carbonate or sulfate minerals, analogous to such processes for calcium and strontium (see Section 2.3.2). Figure 2.22 shows the Eh-pH region (tan-colored area) in which the mineral bromellite $(\mathrm{BeO})$ calculates to be oversaturated for a total concentration of $1 \times 10^{-8} \mathrm{~mol} / \mathrm{L}$ dissolved beryllium based on the available thermodynamic data. The area of oversaturation includes an extensive $\mathrm{pH}$ range from approximately 4.5 to 11.5 . Although bromellite was identified as a possible solubility control based solely on equilibrium thermodynamic considerations (Figure 2.22), this author (KMK), however, did not identify any information that discusses the likelihood of this mineral precipitating at geochemical conditions associated with soil and groundwater systems. Based on the results of laboratory adsorption studies of beryllium onto albite and biotite, Aldahan et al. (1999) (discussed further below) have suggested that the precipitation of solid $\mathrm{Be}(\mathrm{OH})_{2}{ }^{(\mathrm{a})}$ may control beryllium concentrations in aqueous systems at basic $\mathrm{pH}$ conditions. In adsorption experiments conducted at $\mathrm{pH} 7$ and 9, Aldahan et al. (1999) observed a rapid (within a few hours) decrease of approximately three orders of magnitude to $10^{-6} \mathrm{~mol} / \mathrm{L}$ in the concentration of dissolved beryllium. The adsorption measurements conducted at $\mathrm{pH} 6$, however, only resulted in a decrease in dissolved beryllium concentrations of less than an order of magnitude. Aldahan et al. (1999) proposed that the large decrease in the dissolved beryllium concentrations determined at basic $\mathrm{pH}$ conditions resulted from the precipitation of solid $\mathrm{Be}(\mathrm{OH})_{2}$ and not adsorption processes.

Given the low concentrations of beryllium expected for most environmental conditions, the mobility of beryllium in soils is likely controlled by adsorption processes, but very little is known about these process for beryllium (Kaste et al. 2002, Veselý et al. 2002, and Rai et al. 1984). Adsorption studies of beryllium on soils and other geologic materials are limited, and beryllium $K_{d}$ values are not included in compiled $K_{d}$ databases, such as Thibault et al. (1990). Rai et al. (1984) also note that no information is available to determine the relative importance of ion exchange versus specific adsorption mechanisms with respect to the adsorption of beryllium by soil. The available adsorption studies indicate that beryllium is strongly adsorbed to geologic materials under neutral $\mathrm{pH}$ conditions in environmental systems and is a function of $\mathrm{pH}$, mineralogy, ionic strength of the solution, and mineral surface properties (Veselý et al. 2002 and references therein). Beryllium adsorption has been observed to increase by four orders of magnitude from $\mathrm{pH} 2$ to 6 (Veselý et al. 2002). In the adsorption studies cited by Veselý et al. (2002), $\mathrm{K}_{\mathrm{d}}$ values have been reported in the range of $10^{4}$ to $10^{6} \mathrm{~mL} / \mathrm{g}$. However, as noted in EPA (1999a), adsorption resulting in very large $K_{d}$ values may have been compromised by precipitation processes. Aldahan et al. (1999) completed laboratory adsorption studies of

(a) The solid $\mathrm{Be}(\mathrm{OH})_{2}$ and its thermodynamic data are not included in the database for The Geochemist's Workbench $^{\circledR}$ (Version 4.0) software package. 
beryllium onto albite and biotite. As discussed above, Aldahan et al. (1999) attributed the large decreases in the dissolved beryllium concentrations and similar $\mathrm{K}_{\mathrm{d}}$ values obtained in their experiments conducted at basic $\mathrm{pH}$ conditions to the precipitation of solid $\mathrm{Be}(\mathrm{OH})_{2}$. Aldahan et al. (1999) proposed that this precipitation process was also responsible for the similar large $\mathrm{K}_{\mathrm{d}}$ values measured in the $\mathrm{pH}$ range from 6 to 12 by others, such as Brown et al. (1992) and You et al. $(1989,1994)$.

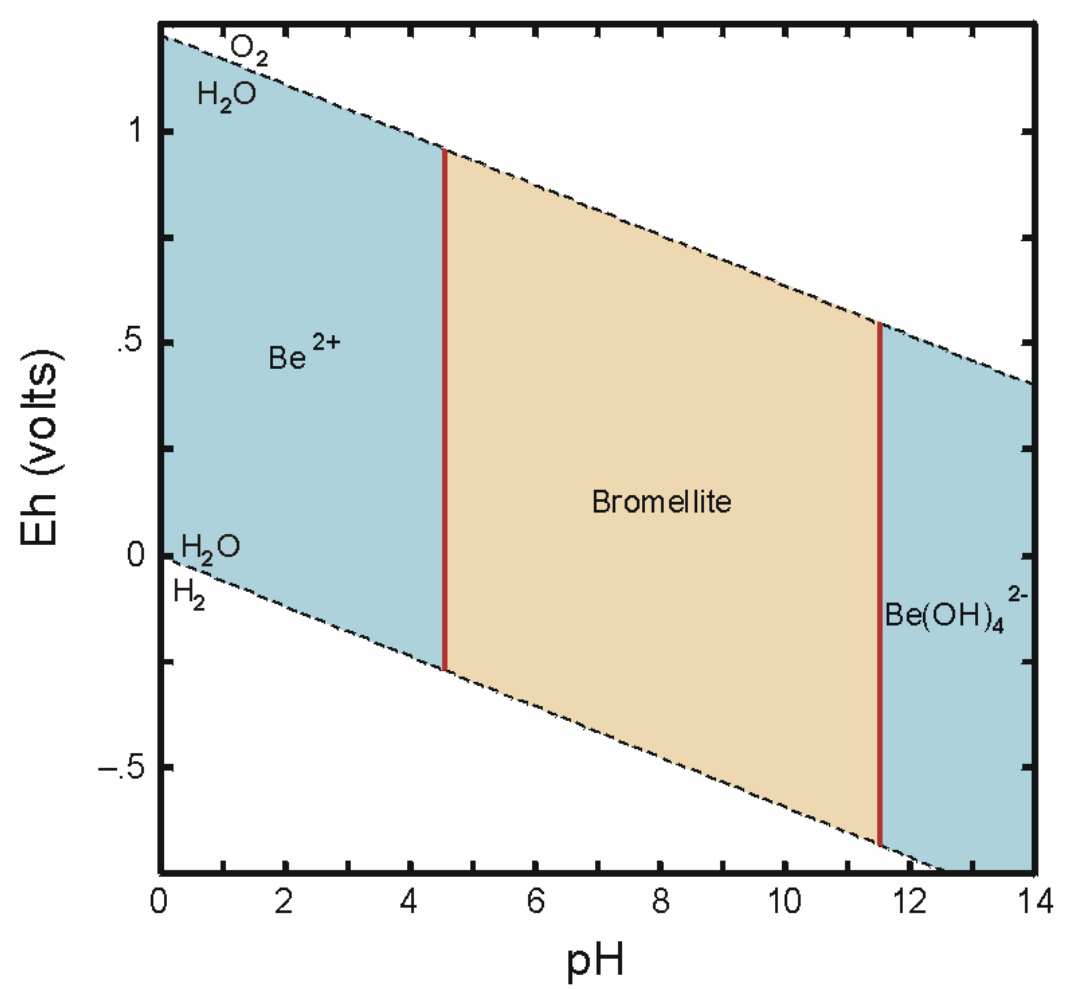

Figure 2.22. Diagram Showing Eh-pH Region (Tan Colored) that Calculates to be Oversaturated with Respect to the Solubility of Bromellite $(\mathrm{BeO})$ (diagram was calculated at a total concentration of $1 \times 10^{-8} \mathrm{~mol} / \mathrm{L}$ dissolved beryllium at $\left.25^{\circ} \mathrm{C}\right)$

\subsubsection{Nickel-59,63 $\left({ }^{63,59} \mathrm{Ni}\right)$}

Compared to other radionuclides and inorganic contaminants of environmental interest, the geochemical behavior of nickel in soil and groundwater systems has not been studied extensively. Nriagu (1980) includes a compilation of papers pertaining to the biological, chemical, geological, and clinical properties of nickel. Of these papers, those by Richter and Theis (1980) and Snodgrass (1980) discuss the speciation and behavior of nickel in soil-water systems and may be of interest to readers of this review. Rai et al. (1984) present a detailed review of the aqueous speciation, solubility, and adsorption reactions that affect the environmental mobility of nickel. 
In aqueous systems, the most important oxidation state of nickel is +2 (Baes and Mesmer 1976). The Eh-pH diagram in Figure 2.23 shows the dominant aqueous species for dissolved nickel that were calculated for a concentration of $1 \times 10^{-8} \mathrm{~mol} / \mathrm{L}$ total dissolved nickel and the ligand concentrations listed in Table 2.2. At $\mathrm{pH}$ values less than 10, the uncomplexed cation $\mathrm{Ni}^{2+}$ is predicted to be the dominant aqueous species of nickel. At $\mathrm{pH}$ values greater than 10, dissolved nickel is present as a series of hydroxide species. Nickel also forms aqueous complexes to a limited degree with ligands, such as dissolved sulfate, carbonate, and chloride (Rai et al. 1984), but these species were not predicted to be dominant for the conditions and thermodynamic values used to calculate Figure 2.23.

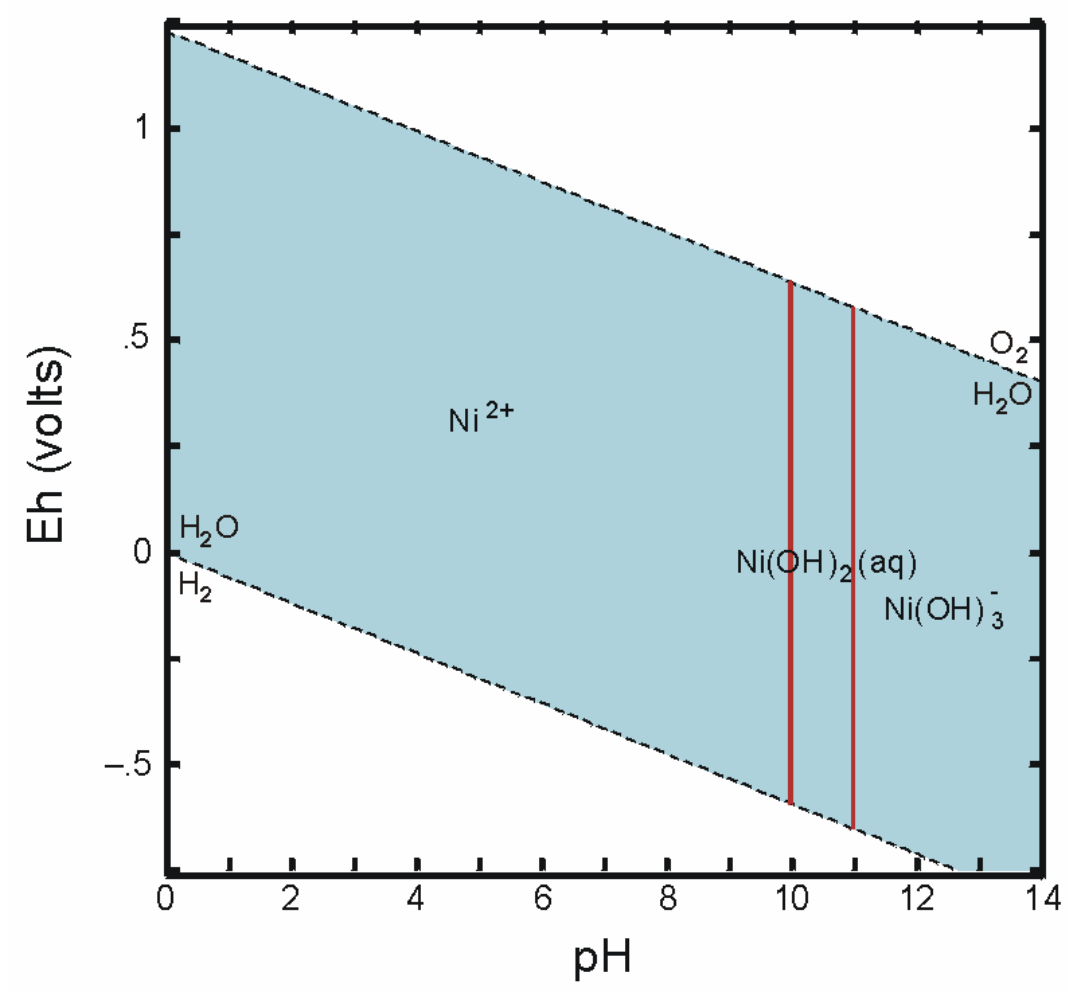

Figure 2.23. Eh-pH Diagram Showing Dominant Aqueous Species of Nickel (diagram was calculated at a total concentration of $1 \times 10^{-8} \mathrm{~mol} / \mathrm{L}$ dissolved nickel at $25^{\circ} \mathrm{C}$ )

Based on the ligand concentrations in Table 2.2, an aqueous solution containing a total concentration of dissolved nickel of $10^{-8} \mathrm{~mol} / \mathrm{L}$ calculates to be oversaturated with respect to the several nickel sulfide minerals (tan-colored areas in Figure 2.24) under highly reducing conditions in the presence of dissolved sulfide. The predicted stable sulfide minerals include vaesite $\left(\mathrm{NiS}_{2}\right)$, heazlewoodite $\left(\mathrm{Ni}_{3} \mathrm{~S}_{2}\right)$, and polydymite $\left(\mathrm{Ni}_{3} \mathrm{~S}_{4}\right)$. Under these geochemical conditions, nickel may potentially precipitate in soils and control the maximum concentration of total dissolved nickel. The results of a solubility study by Mattigod et al. (1997) indicate that solid $\mathrm{Ni}(\mathrm{OH})_{2}$ (the mineral theophrastite) may precipitate and control the maximum concentration of dissolved nickel in soils under alkaline conditions. At concentrations of dissolved nickel less than $10^{-7} \mathrm{~mol} / \mathrm{L}$, our solubility calculations indicate that bunsenite $(\mathrm{NiO})$ is 
oversaturated at basic $\mathrm{pH}$ values. However, the revised stability constant for crystalline $\mathrm{Ni}(\mathrm{OH})_{2}$ determined by Mattigod et al. (1997) was not in the thermodynamic database used to calculate the Eh-pH diagram in Figure 2.24.

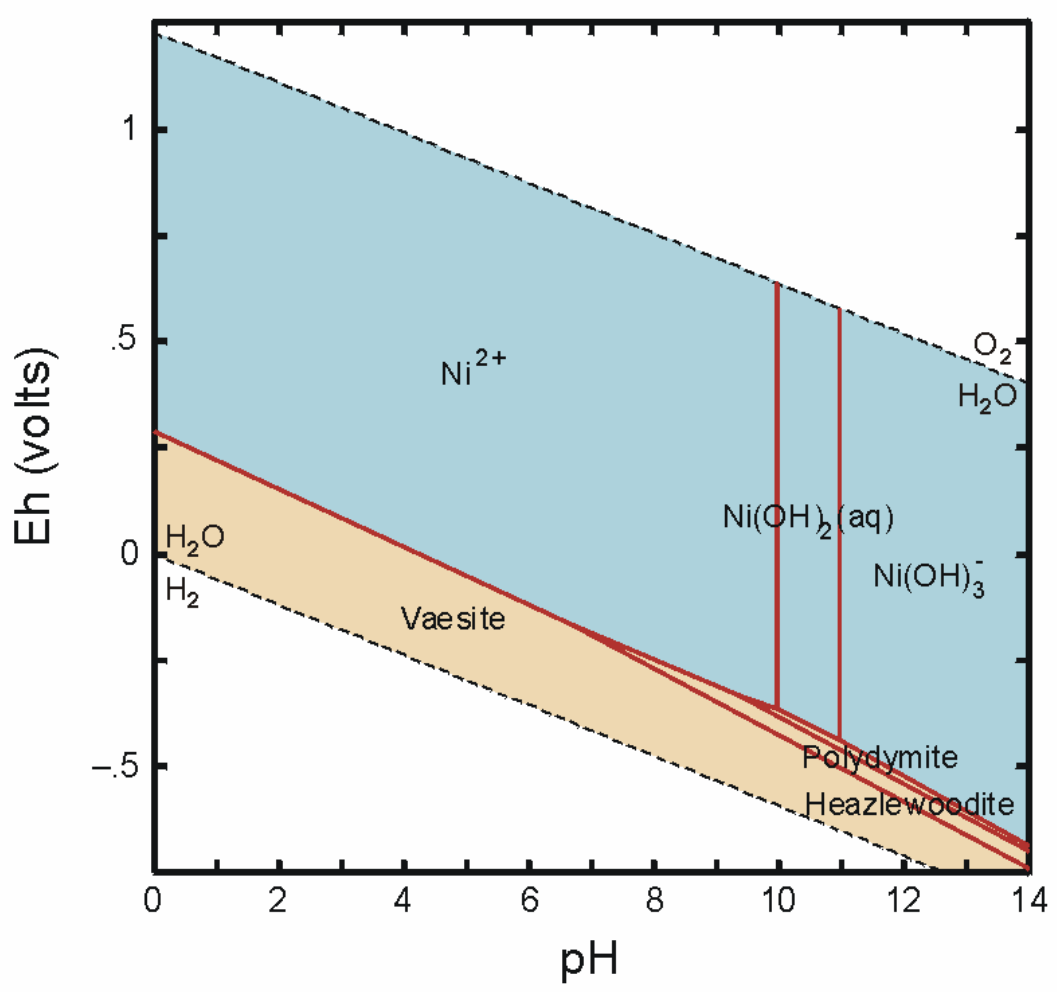

Figure 2.24. Diagram Showing Eh-pH Region (Tan Colored) that Calculates to be Oversaturated with Respect to the Solubility of Nickel Solids (diagram was calculated at a total concentration of $1 \times 10^{-8} \mathrm{~mol} / \mathrm{L}$ dissolved nickel at $25^{\circ} \mathrm{C}$ )

The concentrations of nickel in most soil systems are likely controlled by surface sorption processes. Nickel is known to be adsorbed by iron and manganese oxides and clays (Rai et al. 1984 and references therein). The $\mathrm{K}_{d}$ values compiled by Thibault et al. (1990) indicate that nickel is moderately to highly sorbed by soils with $\mathrm{K}_{\mathrm{d}}$ values ranging from several tens to several thousands milliliters per gram. The adsorption of nickel is $\mathrm{pH}$ dependent. The adsorption of the uncomplexed cation $\mathrm{Ni}^{2+}$ (Figure 2.24) will be greatest at high $\mathrm{pH}$ values less than 11, decrease with deceasing $\mathrm{pH}$, and be minimal at acidic conditions. At $\mathrm{pH}$ values greater than 11 , the adsorption of nickel to soil may decrease if the dominant nickel aqueous species is anionic, such as $\mathrm{Ni}(\mathrm{OH})_{3}{ }^{-}$. Recent studies by Nachtegaal and Sparks (2003), Elzinga and Sparks $(1999,2001)$, Scheckel and Sparks $(2000,2001)$, and other related papers by these authors demonstrate that the sorption of nickel to some clay minerals results in the formation of nickel hydroxide or nickelaluminum hydroxide surface precipitates on the clays. The formation of such surface precipitates will reduce the migration and remobilization of nickel in soil-water systems. 


\subsubsection{Niobium-94 $\left({ }^{94} \mathrm{Nb}\right)$}

Essentially no information is available in the literature regarding the environmental behavior of niobium in sediments and aqueous systems. Niobium is not included in the reviews of radionuclide environmental behavior by Ames and Rai (1978) or Onishi et al. (1981), or the compilation of radionuclide thermodynamic data by Phillips et al. (1988).

Baes and Mesmer (1976) indicate that niobium will be present in the +5 oxidation state over the entire Eh-pH stability range of water. Based on the estimated stability constants from Babko et al. (1963), Baes and Mesmer (1976) estimated that the dominant hydrolysis species for dissolved niobium would be $\mathrm{Nb}(\mathrm{OH})_{5}{ }^{ }$(aq) and $\mathrm{Nb}(\mathrm{OH})_{6}{ }^{-}$at $\mathrm{pH}$ values less than and greater than 7.4, respectively. Baes and Mesmer (1976) caution however that these calculations are very approximate.

Wagman et al. (1982) list thermodynamic constants for several niobium solids, such as $\mathrm{Nb}_{2} \mathrm{O}_{5}$, and the three niobium aqueous species $\mathrm{Nb}(\mathrm{OH})_{4}{ }^{+}, \mathrm{Nb}(\mathrm{OH})_{5}{ }^{\circ}$ (aq) and $\mathrm{Nb}(\mathrm{OH})_{6}{ }^{-}\left(=\mathrm{NbO}_{3}{ }^{-}\right.$ $+3 \mathrm{H}_{2} \mathrm{O}$ ). However, the constants listed for the niobium aqueous species only apply to an ionic strength of $1 \mathrm{M}$ (Wagman et al. 1982).

More recently, Hummel et al. (2002) document the current thermodynamic database developed for the Swiss Nagra ${ }^{(a)}$ nuclear waste program. Their database for niobium species is also very limited. Hummel et al. (2002) note that the $\mathrm{Nb}_{2} \mathrm{O}_{5}$ solubility measurements reviewed by Lothenbach et al. (1999) ${ }^{(b)}$ indicate the presence of a negatively charged aqueous species in the $\mathrm{pH}$ range from 7 to 10 . Based on this observation, Hummel et al. (2002) assumed that $\mathrm{Nb}(\mathrm{OH})_{6}{ }^{-}$ was the dominant species under these conditions. In neutral and acidic $\mathrm{pH}$ conditions, the solubility measurements suggest the presence of an uncharged aqueous species, which Hummel et al. (2002) assumed to be $\mathrm{Nb}(\mathrm{OH})_{5}{ }^{\mathrm{o}}$ (aq).

None of the literature sources identified in our review list any information regarding the complexation of dissolved niobium by inorganic or organic ligands other than hydroxide. Assuming $\mathrm{Nb}(\mathrm{OH})_{6}{ }^{-}$is the dominant niobium aqueous species in natural waters at $\mathrm{pH}$ values greater than 7, it would be appropriate to assume that niobium would be fairly mobile because it would not significantly adsorb to soils because of the negative surface charge of mineral surfaces under these $\mathrm{pH}$ conditions.

\subsubsection{Silver-108m $\left({ }^{108 m} \mathrm{Ag}\right)$}

The geochemistry of silver ore mineralization has been studied extensively because of the importance of silver as a precious metal and its use in certain industrial processes. Smith and Carson (1977) reviewed the production, uses, natural-environmental levels, anthropogenic sources, human and animal health effects, and environmental impacts of silver. However, the environmental behavior of silver in soil and groundwater systems has received less attention.

(a) Nagra = Nationale Genossenschaft für die Lagerung Radioaktiver Abfälle (National Cooperative for the Disposal of Radioactive Waste).

(b) Reference by Lothenbach et al. (1999) not available for our review. 
Silver can exist in $0,+1,+2$, and +3 oxidation states. In soil systems, only the 0 and +1 oxidation states are important (Lindsay 1979). The Eh-pH diagram in Figure 2.25 shows the dominant silver aqueous species calculated at $25^{\circ} \mathrm{C}$ using a total concentration of $1 \times 10^{-8} \mathrm{~mol} / \mathrm{L}$ dissolved silver and the ligand concentrations listed in Table 2.2. These calculations indicate that dissolved silver will be present predominantly as the uncomplexed $\mathrm{Ag}^{+}$ion throughout the entire $\mathrm{pH}$ range up to approximately a $\mathrm{pH}$ of 11.4. At $\mathrm{pH}$ values greater than 11.4, the carbonate complex $\mathrm{AgCO}_{3}{ }^{-}$is predicted to be the dominant aqueous complex of silver at these geochemical conditions. Like most monovalent ions, $\mathrm{Ag}^{+}$only has a small tendency to form aqueous hydroxide complexes (Baes and Mesmer 1976). Silver may form stable aqueous chloride, nitrate, or sulfate complexes in waters having high concentrations of these ligands (Smith and Carson 1977), and under reducing conditions in the presence of dissolved sulfide, silver may be present as aqueous sulfide complexes, such as $\mathrm{AgHS}^{\circ}$ (aq) and $\mathrm{Ag}(\mathrm{HS})_{2}{ }^{-}$(Bell and Kramer 1999; Smith and Carson 1977).

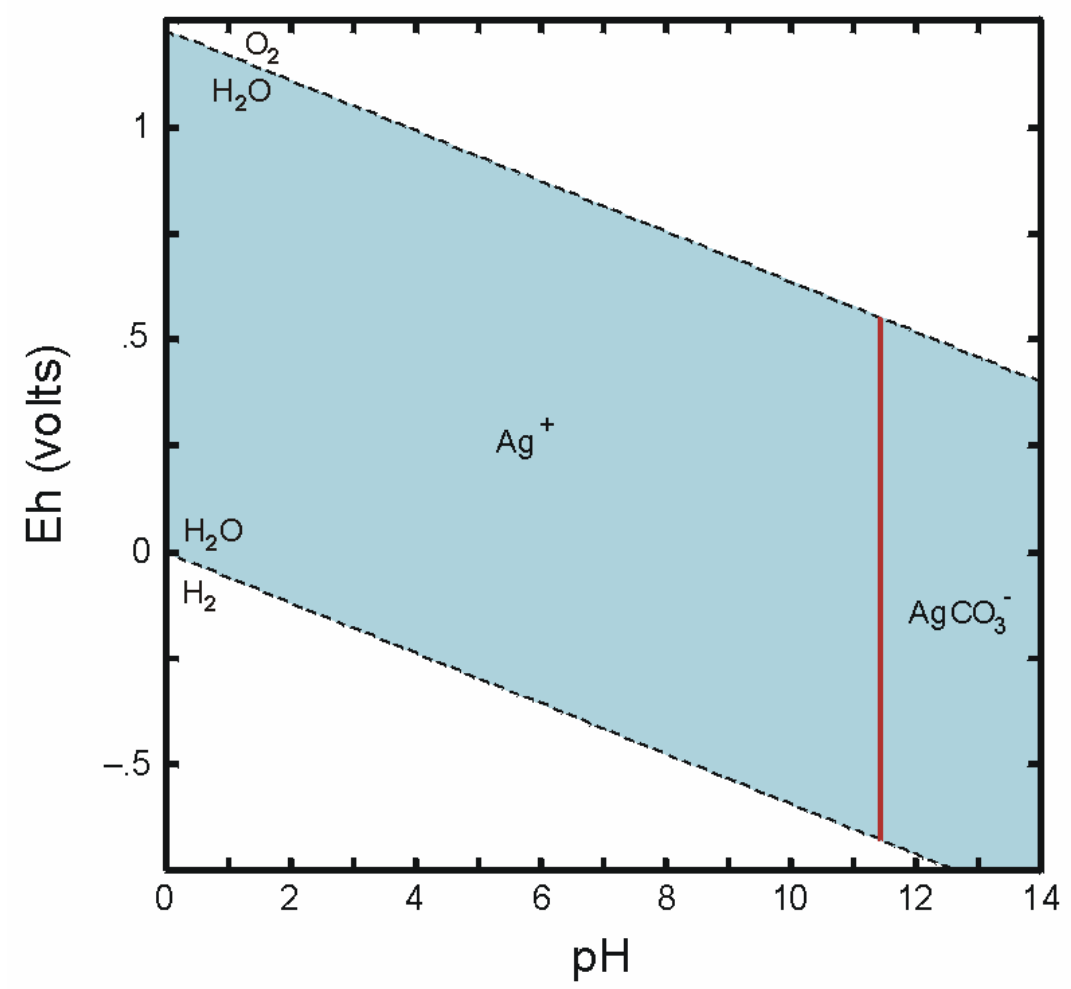

Figure 2.25. Eh-pH Diagram Showing Dominant Aqueous Species of Silver (diagram was calculated at a total concentration of $1 \times 10^{-8} \mathrm{~mol} / \mathrm{L}$ dissolved silver at $25^{\circ} \mathrm{C}$ )

The concentration of silver in soils under certain conditions may be controlled by solubility processes. Lindsay (1979) reviews the solubility of silver in soil systems. Based on the ligand concentrations in Table 2.2, an aqueous solution containing a total concentration of dissolved silver of $10^{-8} \mathrm{~mol} / \mathrm{L}$ calculates to be oversaturated with respect to the solubility of acanthite $\left(\mathrm{Ag}_{2} \mathrm{~S}\right)$ over the entire $\mathrm{pH}$ range under highly reducing conditions (Figure 2.26). Under oxidizing to moderately reducing conditions, this system calculates to be undersaturated with respect to the solubilities of silver solids available in the thermodynamic database. In highly 
saline soils in arid regions, silver may also be present as $\mathrm{AgCl}, \mathrm{AgBr}$, or $\mathrm{AgI}$ solids (Smith and Carson 1977). Metallic silver also calculates to be a potential solubility control for silver under certain reducing soil conditions (Lindsay 1979).

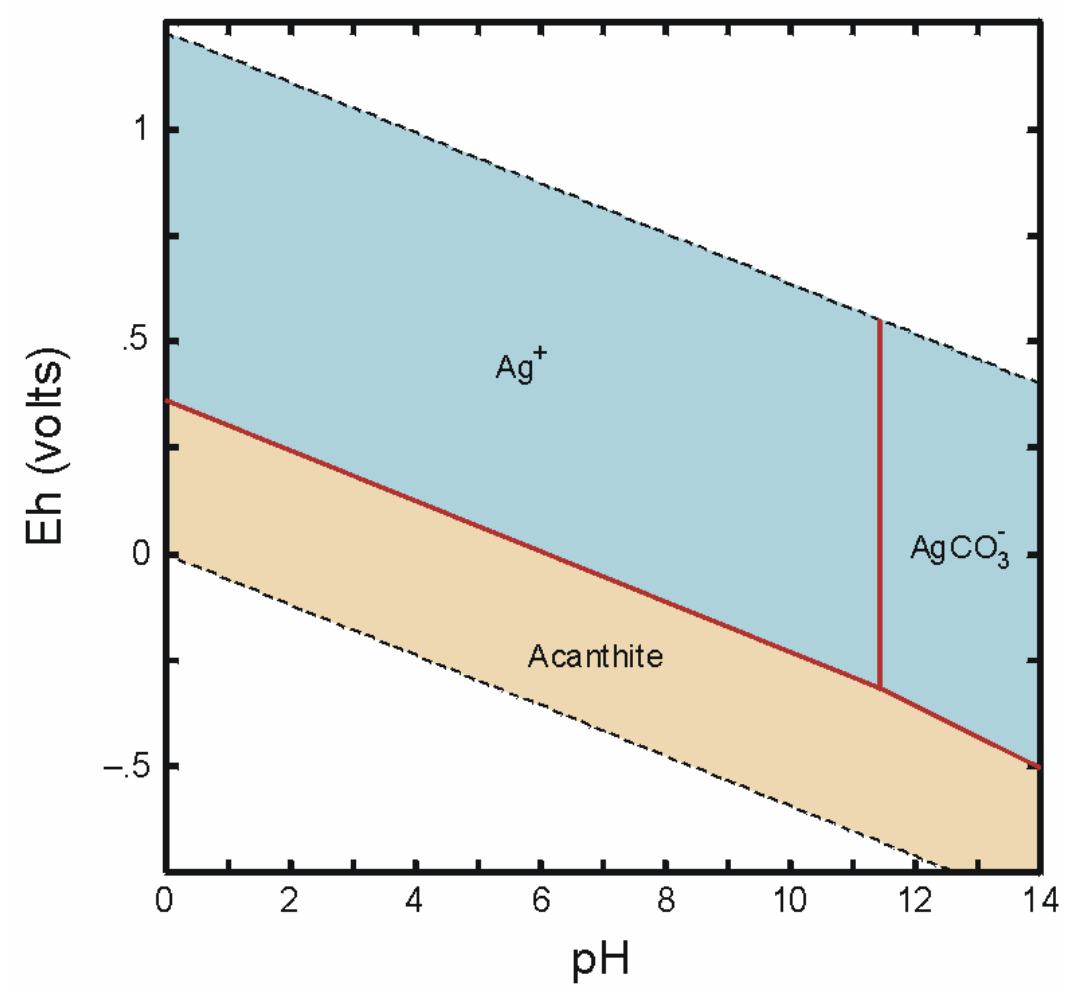

Figure 2.26. Diagram Showing Eh-pH Region (tan colored) that Calculates to be Oversaturated with Respect to the Solubility of Acanthite $\left(\mathrm{Ag}_{2} \mathrm{~S}\right)$ (diagram was calculated at a total concentration of $1 \times 10^{-8} \mathrm{~mol} / \mathrm{L}$ dissolved silver at $25^{\circ} \mathrm{C}$ )

In most soils, the concentrations of silver are expected to be controlled by adsorption to iron and manganese oxide minerals, clays, and organic matter (Smith and Carson 1977). As with the adsorption of most dissolved metals, the solution $\mathrm{pH}$ should have a significant effect on silver adsorption because of the consequence of $\mathrm{pH}$ on aqueous speciation and the number of exchange sites on variable charged surfaces of solids. The adsorption of the uncomplexed cation $\mathrm{Ag}^{+}$ (Figure 2.25) will be greatest at high $\mathrm{pH}$, decrease with deceasing $\mathrm{pH}$, and be minimal at acidic conditions. If the aqueous speciation calculations illustrated in Figure 2.25 are valid for silver in soil and groundwater systems, then the adsorption of silver should decrease at $\mathrm{pH}$ values greater than 11 because of the formation of the anionic complex $\mathrm{AgCO}_{3}{ }^{-}$. Thibault et al. (1990) compiled and reviewed published $\mathrm{K}_{\mathrm{d}}$ data for silver as a function of different soil types. Their study identified only a limited number of $\mathrm{K}_{\mathrm{d}}$ data published for silver. Generally, these $\mathrm{K}_{\mathrm{d}}$ values suggest that silver is moderately to highly adsorbed in sand-, silt-, and clay-rich soils. Although a $\mathrm{K}_{\mathrm{d}}$ value as low as $3 \mathrm{~mL} / \mathrm{g}$ was reported, the $\mathrm{K}_{\mathrm{d}}$ values for silver in Thibault et al. (1990) typically ranged from several tens to several hundred milliliters per gram for these three soil types. Thibault et al. (1990) listed only four $\mathrm{K}_{\mathrm{d}}$ values for silver uptake by organic-rich soil 
material, and these values were based on a single published study. This study indicated that silver was highly adsorbed by organic matter, with the four $\mathrm{K}_{\mathrm{d}}$ values ranging from 4,400 to $33,000 \mathrm{~mL} / \mathrm{g}$ (as listed by Thibault et al. 1990). However, as noted previously, EPA (1999b) cautions users of $K_{d}$ data that the studies resulting in very large $K_{d}$ values may have been affected by the precipitation of solids containing the contaminant of interest during the equilibration of the spiked aqueous solutions with soil.

\subsection{Section 2 References}

54 FR 22578-27583. 1989. “Disposal of Radioactive Waste.” Federal Register. Final Rule, 10 CFR 61, May, 1989.

Aas W, E Steinle, Th. Fanghänel, and JI Kim. 1999. "Thermodynamics of Cm(III) in Concentrated Solutions. Fluoride Complexation in $0-5 \mathrm{~m} \mathrm{NaCl}$ at $25^{\circ} \mathrm{C}$." Radiochimica. Acta. 84:85-88.

Aldahan A, Y Haiping, and G Possnert. 1999. "Distribution of Beryllium between Solution and Minerals (Biotite and Albite) under Atmospheric Conditions and Variable pH." Chem. Geol. 156:209-229.

Al Mahamid I, CF Novak, KA Becraft, SA Carpenter, and N Hakem. 1998. "Solubility of $\mathrm{Np}(\mathrm{V})$ in $\mathrm{K}-\mathrm{Cl}-\mathrm{CO}_{3}$ and $\mathrm{Na}-\mathrm{K}-\mathrm{Cl}-\mathrm{CO}_{3}$ Solutions to High Concentrations: Measurements and Thermodynamic Model Predictions.” Radiochimica. Acta. 81:93-101.

Allard B. 1984. "Mechanisms for the Interaction of Americium(III) and Neptunium(V) with Geologic Media." In Scientific Basis for Nuclear Waste Management VII, ed. GL McVay, vol. 26, pp. 899-906. Materials Research Society Symposium Proceedings, North-Holland, NY.

Allard B, and J Rydberg. 1983. "Behavior of Plutonium in Natural Waters." In Plutonium Chemistry, ACS Symposium Series 216, eds. WT Carnall and GR Choppin, pp. 275-295. American Chemical Society, Washington, D.C.

Ames LL, JE McGarrah, BA Walker, and PF Salter. 1982. "Sorption of Uranium and Cesium by Hanford Basalts and Associated Secondary Smectite.” Chemical Geology 35:205-225.

Ames LL, and D Rai. 1978. Radionuclide Interactions with Soil and Rock media. Volume 1: Processes Influencing Radionuclide Mobility and Retention, Element Chemistry and Geochemistry, and Conclusions and Evaluations. EPA 520/6-78-007-a, U.S. Environmental Protection Agency, Las Vegas, NV.

Artinger R, CM Marquardt, JI Kim, A Seibert, N Trautmann, and JV Kratz. 2000. "Humic Colloid-Borne Np Migration: Influence of the Oxidation State." Radiochimica. Acta. 88:609-612.

Ashby JR, and PJ Craig. 1988. "Environmental Methylation of Tin: An Assessment." Sci. Total Environ. 73:127-133. 
Aston SR. 1980. "Evaluation of Chemical Forms of Plutonium in Seawater." Marine Chemistry 8:317-326.

Babko AK, VV Lukochina, and BI Nabivanets. 1963. "Solubility and Acid-Base Properties of Tantalum and Niobium Hydroxide." Russian Journal of Inorganic Chemistry 8:957-961.

Baes CF, Jr., and RE Mesmer. 1976. The Hydrolysis of Cations. John Wiley and Sons, NY.

Baes CF, Jr., and RD Sharp. 1983. "A Proposal for Estimation of Soil Leaching Constants for Use in Assessment Models." Journal of Environmental Quality 12:17-28.

Beasley TM, and HV Lorz. 1984. "A Review of the Biological and Geochemical Behavior of Technetium in the Marine Environment." In Technetium in the Environment, eds. G Desment and C Myttenaere, pp. 197-216. Elsevier, NY.

Behrens H. 1982. "New Insights Into the Chemical Behavior of Radioiodine in Aquatic Environments." In Environmental Migration of Long-Lived Radionuclides, pp. 27-40. International Atomic Energy Agency, Vienna, Austria.

Bell RA, and JR Kramer. 1999. "Structural Chemistry and Geochemistry of Silver-Sulfur Compounds: Critical Review." Environ. Toxicol. Chem. 18:9-22.

Bird GA, and W Schwartz. 1996. "Distribution Coefficients, $\mathrm{K}_{\mathrm{d}}$ 's, for Iodide in Canadian Shield Lake Sediments Under Oxic and Anoxic Conditions." Journal of Environmental Radioactivity 35:261-279

Boggs S, Jr., D Livermore, and MG Seitz. 1985. Humic Substances in Natural Waters and Their Complexation with Trace Metals and Radionuclides: A Review. ANL-84-78, Argonne National Laboratory, Argonne, IL.

Bondietti EA, and CW Francis. 1979. "Geologic Migration Potentials of Technetium-99 and Neptunium-237.” Science 203:1337-1340.

Bondietti EA, and JR Trabalka. 1980. "Evidence for Plutonium(V) in an Alkaline, Freshwater Pond." Radioanalytical Letters 43:169-176.

Borovec Z, B Kribek, and V Tolar. 1979. "Sorption of Uranyl by Humic Acids." Chemical Geology 27:39-46.

Bovard P, A Grauby, and A Saas. 1968. "Chelating Effect of Organic Matter and Its Influence on the Migration of Fission Products." In Isotopes and Radiation in Soil Organic Matter Studies, STI/PUB-190 (CONF-680725), Proceedings Series, pp. 471-495. International Atomic Energy Agency (IAEA), Vienna, Austria. 
Brown ET, JM Edmond, GM Raisbeck, DL Bourlés, F Yiou, and Ch. Measure. 1992. "Beryllium Isotope Geochemistry in Tropical River Basins." Geochim. et Cosmo. Acta, 56:1607-1624.

Burns PC, and R Finch, eds. 1999. Uranium: Mineralogy, Geochemistry and the Environment. Reviews in Mineralogy," vol. 38. Mineralogical Society of America, Washington, D.C.

Byegård J, Y Albinsson, G Skarnemark, and M Skålberg. 1992. "Field and Laboratory Studies of the Reduction and Sorption of Technetium(VII)." Radiochimica. Acta. 58/59:239-244.

Cantrell KJ, RJ Serne, and GV Last. 2002. Hanford Contaminant Distribution Coefficient Database and Users Guide. PNNL-13895, Pacific Northwest National Laboratory, Richland, WA.

Chasteen TG. 1998. "Volatile Chemical Species of Selenium." In Environmental Chemistry of Selenium, W. T. Frankenberger, Jr., and R. A. Engberg (Eds.), pp. 589-612, Marcel Dekker, Inc., New York, NY.

Chisholm-Brause C, SD Conradson, CT Buscher, PG Eller, and DE Morris. 1994. "Speciation of Uranyl Sorbed at Multiple Binding Sites on Montmorillonite." Geochimica. et.

Cosmochimica. Acta. 58(17):3625-3631.

Choppin GR. 1989. "Soluble Rare Earth and Actinide Species in Seawater." Marine Chemistry 28:1926.

Choppin GR. 1992. "The Role of Natural Organics in Radionuclide Migration in Natural Aquifer Systems.” Radiochimica. Acta. 58/59:113-120.

Clark SB, AL Bryce, AD Lueking, J Gariboldi, and SM Serkiz. 1998. "Factors Affecting Trivalent $f$-Element Adsorption to an Acidic Sandy Soil." In Adsorption of Metals by Geomedia. Variables, Mechanisms, and Model Applications, ed. EA Jenne, pp. 149-164. Academic Press, San Diego, CA.

Cleveland JM. 1979. The Chemistry of Plutonium. American Nuclear Society, LaGrange Park, IL.

Cotton FA, and G Wilkinson. 1980. Advanced Inorganic Chemistry. A Comprehensive Text. John Wiley and Sons, NY.

Coughtrey PJ, D Jackson, CH Jones, P Kane, and MC Thorne. 1984. Radionuclide Distribution and Transport in Terrestrial and Aquatic Ecosystems. A Critical Review of Data. AA Balkema, Boston, MS.

Coughtrey PJ, D Jackson, and MC Thorne. 1983. Radionuclide Distribution and Transport in Terrestrial and Aquatic Ecosystems. A Critical Review of Data. AA Balkema, Rotterdam, Netherlands. 
Coughtrey PJ, D Jackson and MC Thorne. 1985. Radionuclide Distribution and Transport in Terrestrial and Aquatic Ecosystems. A Compendium of Data. AA Balkema, Netherlands.

Deer WA, RA Howie, and J Zussman. 1967. Rock-Forming Minerals. Volume 1. Ortho- and Ring Silicates. Longmans, London, England.

Delegard CH. 1987. "Solubility of $\mathrm{PuO}_{2} \cdot \mathrm{xH}_{2} \mathrm{O}$ in Alkaline Hanford High-Level Waste Solution." Radiochimica. Acta. 41:11-21.

Doner HE, and WC Lynn. 1977. "Carbonate, Halide, Sulfate, and Sulfide Minerals." In Minerals in Soil Environments, eds. JB Dixon and SB Weed, pp. 75-98. Soil Society of America, Madison, WI.

Douglas LA. 1989. "Vermiculites." In Minerals in Soil Environments, J. B. Dixon and S. B. Week (Eds.), Second Edition, pp. 635-674, Soil Science Society of America, Madison, WI.

Efurd D, W Runde, JC Banar, DR Janecky, JP Kaszuba, PD Palmer, FR Roensch, and CD Tait. 1998. "Neptunium and Plutonium Solubilities in a Yucca Mountain Groundwater." Applied Geochem. 32:3893-3900.

Elrashidi MA, DC Adriano, and WL Lindsay. 1989. "Solubility, Speciation, and Transformations of Selenium in Soils." In Selenium in Agriculture and the Environment, LW Jacobs (Ed.), pp. 51-63, SSSA Special Publication Number 23, Soil Science Society of America, Inc., Madison, WI.

Elzinga EJ, and DL Sparks. 1999. "Nickel Sorption Mechanisms in a PyrophylliteMontorillonite Mixture.” J. Coll. Inter. Sci. 213:506-512.

Elzinga EL, and DL Sparks. 2001. "Reaction Condition Effects on Nickel Sorption Mechanisms in Illite-Water Suspensions.” Soil Sci. Soc. America J. 65:94-101.

EPA, see U.S. Environmental Protection Agency

Eriksen TE, and D Cui. 1991. On the Interaction of Granite with Tc(IV) and Tc(VII) in Aqueous Solution. SKB Technical Report 91-47, Svensk Kärnbränslehantering AB (Swedish Nuclear Fuel and Waste Management Company), Stockholm, Sweden.

Eriksen TE, P Ndalamba, J Bruno, and M .Caceci. 1992. "The Solubility of $\mathrm{TcO}_{2} \mathrm{AnH}_{2} \mathrm{O}$ in Neutral to Alkaline Solutions under Constant $\mathrm{p}_{\mathrm{CO} 2}$." Radiochimica. Acta. 58/59:67-70.

Eslinger PW, LA Doremus, DW Engel, TB Miley, MT Murphy, WE Nichols, MD White, DW Langford, and SJ Ouderkirk. 1993. Preliminary Total-System Analysis of Potential High-Level Nuclear Waste Repository at Yucca Mountain. PNL-8444, Pacific Northwest National Laboratory, Richland, WA. 
Falck WE. 1991. CHEMVAL Project. Critical Evaluation of the CHEMVAL Thermodynamic Database with Respect to its Contents and Relevance to Radioactive Waste Disposal at Sellafield and Dounreay. DOE/HMIP/RR/92.064, Department of Environment, Her Majesty's Stationary Office, London, England.

Fanghänel Th, HT Weger, Th Könnecke, V Neck, P Paviet-Hartmann, E Steinle, and JI Kim. 1998. "Thermodynamics of Cm(III) in Concentrated Electrolyte Solutions. Carbonate Complexation at Constant Ionic Strength $(1 \mathrm{~m} \mathrm{NaCl})$." Radiochimica. Acta. 82:47-53.

Faure G, and JL Powell. 1972. Strontium Isotope Geology. Springer-Verlag, Berlin, Germany.

Felmy AR, D Rai, and RW Fulton. 1990. "The Solubility of $\mathrm{AmOHCO}_{3}(\mathrm{c})$ and the Aqueous Thermodynamics if the System $\mathrm{Na}^{+}-\mathrm{Am}^{3+}-\mathrm{HCO}_{3}{ }^{-}-\mathrm{CO}_{3}{ }^{2-}-\mathrm{OH}^{-}-\mathrm{H}_{2} \mathrm{O}$." Radiochimica. Acta. 50:193-204.

Felmy AR, D Rai, and MJ Mason. 1991. "The Solubility of Hydrous Thorium(IV) Oxide in Chloride Media: Development of an Aqueous Ion-Interaction Model." Radiochimica. Acta. $55: 177-185$.

Finch R, and T Murakami. 1999. "Systematics and Paragenesis of Uranium Minerals." In Uranium: Mineralogy, Geochemistry and the Environment. Reviews in Mineralogy, eds. PC Burns and R Finch, vol. 38, pp. 91-179. Mineralogical Society of America, Washington, D.C.

Fredrickson JK, HM Kostandarithes, SW Li, AE Plymale, and MJ Daly. 2000. "Reduction of $\mathrm{Fe}(\mathrm{III}), \mathrm{Cr}(\mathrm{VI}), \mathrm{U}(\mathrm{VI})$, and Tc(VII) by Deinococcus radiodurans R1.” Applied and Environmental Microbiology 66:2006-2011.

Frondel C. 1958. "Systematic Mineralogy of Uranium and Thorium. Geological Survey Bulletin 1064. U.S. Geological Survey, Washington, D.C.

Fukui M, Y Fujikawa, and N Sata. 1996. "Factors Affecting Interaction of Radioiodide and Iodate Species with Soil.” J. Environ. Radioact. 31:199-216.

Garrels RM, and CL Christ. 1965. Solutions, Minerals, and Equilibria. Freeman, Cooper and Co., San Francisco, CA.

Gascoyne M. 1982. "Geochemistry of the Actinides and Their Daughters." In Uranium Series Disequilibrium: Applications to Environmental Problems, eds. M Ivanovich and RS Harmon, pp. 33-55. Clarendon Press, Oxford, England.

Gee GW, and AC Campbell. 1980. Monitoring and Physical Characterization of Unsaturated Zone Transport - Laboratory Analysis. PNL-3304, Pacific Northwest Laboratory, Richland, WA. 
Girvin DC, LL Ames, AP Schwab, and JE McGarrah. 1991. "Neptunium Adsorption on Synthetic Amorphous Iron Oxyhydroxide.” J. Colloid Interface Sci. 141:67-78.

Grenthe I, J Fuger, RJM Konings, RJ Lemire, AB Muller, C Nguyen-Trung, and H Wanner. 1992. Chemical Thermodynamics 1: Chemical Thermodynamics of Uranium. North-Holland, Elsevier Science Publishing Company, Inc., NY.

Gu B, and RK Schulz. 1991. Anion Retention in Soil: Possible Application to Reduce Migration of Buried Technetium and Iodine. NUREG/CR-5464, prepared by the University of California at Berkeley, California for the U.S. Nuclear Regulatory Commission, Washington, D.C.

Guo L, WT Frankenberger, Jr, and WA Jury. 1999. “Adsorption and Degradation of Dimethyl Selenide in Soil." Environ. Sci. Tech. 33:2934-2938.

Haines RI, DG Owen, and TT Vandergraaf. 1987. "Technetium-Iron Oxide Reactions Under Anaerobic Conditions: A Fourier Transform Infrared, FTIR Study.” Nucl. J. Canada 1:32-37.

Hakanen M, and A Lindberg. 1991. "Sorption of Neptunium under Oxidizing and Reducing Groundwater Conditions." Radiochimica. Acta. 52/53:147-151.

Hsi C-KD, and D Langmuir. 1985. "Adsorption of Uranyl onto Ferric Oxyhydroxides: Application of the Surface Complexation Site-Binding Model." Geochimica. et Cosmochimica. Acta. 49:1931-1941.

Hughes MA, and FJC Rossotti. 1987. A Review of Some Aspects of the Solution Chemistry of Technetium. AERE-R 12820, University of Oxford, Oxford, England.

Hummel W, U Berner, E Curti, FJ Pearson, and T Thoenen. 2002. Nagra/PSI Chemical Thermodynamic Data Base-01/01. Universal Publishers, Parkland, FL.

Hummel W, MA Glaus, and LR Van Loon. 1999. "Complexation of Radionuclides with Humic Substances: The Metal Concentration Effect." Radiochimica. Acta. 84:111-114.

Idiz EF, D Carlisle, and IR Kaplan. 1986. "Interaction Between Organic Matter and Trace Metals in a Uranium Rich Bog, Kern County, California, U.S.A.” Appl. Geochem. 1:573-590.

Itagaki H, S Tanaka, and M Yamawaki. 1991. "Neptunium Chemical Behavior in Underground Environments Using Ultrafiltration and Centrifugation." Radiochimica. Acta. 52/53:91-94.

Johnson KS. 1994. "Iodine." In Industrial Minerals and Rocks, ed. DC Carr, pp. 583-588. Society for Mining, Metallurgy, and Exploration, Inc., Littleton, CO.

Kaplan DI, PM Bertsch, DC Adriano, and KA Orlandini. 1994. "Actinide Association with Groundwater Colloids in a Coastal Plain Aquifer." Radiochimica. Acta. 66/67:181-187. 
Kaplan DI, RJ Serne, and MG Piepho. 1995. Geochemical Factors Affecting Radionuclide Transport Through Near and Far Fields at a Low-Level Waste Disposal Site. PNNL-10379, Pacific Northwest National Laboratory, Richland, WA.

Kaplan DI, RJ Serne, AT Owen, J Conca, TW Wietsma, and TL Gervais. 1996. Radionuclide Adsorption Distribution Coefficients Measured in Hanford Sediments for the Low Level Waste Performance Assessment Project. PNNL-11485, Pacific Northwest Laboratory, Richland, WA.

Kaplan DI, KE Parker, and IV Kutynakov. 1998a. Radionuclide Distribution Coefficients for Sediments Collected form Borehole 299-E17-21: Final Report for Subtask-1a. PNNL-11966, Pacific Northwest National Laboratory, Richland, WA.

Kaplan DI, KE Parker, and RD Orr. 1998b. Effects of High-pH and High-Ionic-Strength Groundwater on Iodide, Pertechnetate, and Selenate Sorption to Hanford Sediments: Final Report for Subtask 3a. PNNL-11964, Pacific Northwest National Laboratory, Richland, WA.

Kaplan DI, and RJ Serne. 2000. Geochemical Data Package for the Hanford Immobilized LowActivity Tank Waste Performance Assessment (ILAW PA). PNNL-13037, Rev. 1, Pacific Northwest National Laboratory, Richland, WA.

Kaplan D, S Mattigod, K Parker, and G Iversen. 2000a. Experimental Work in Support of the

${ }^{129}$ I-Disposal Special Analysis. WSRC-TR-2000-00283, Rev. 0, Westinghouse Savannah River Company, Aiken, SC.

Kaplan DI, RJ Serne, KE Parker, and IV Kutnyakov. 2000b. "Iodide Sorption to Subsurface Sediments and Illitic Minerals." Environmental Science \& Technology 34:399-405.

Kaste JM, SA Norton, and CT Hess. 2002. "Environmental Chemistry of Beryllium-7." In Beryllium: Mineralogy, Petrology, and Geochemistry. Reviews in Mineralogy and Geochemistry. Volume 50, E. S. Grew (Ed.), pp. 271-289, Mineralogical Society of America, Washington, D.C.

Keeney-Kennicutt WL and JW Morse. 1985. "The Redox Chemistry of $\mathrm{Pu}(\mathrm{V}) \mathrm{O}_{2}{ }^{+}$Interaction with Common Mineral Surfaces in Dilute Solutions and Seawater." Geochimica. Cosmochimica. Acta. 49:2577-2588.

Kent DB, VS Tripathi, NB Ball, JO Leckie, and MD Siegel. 1988. Surface-Complexation Modeling of Radionuclide Adsorption in Subsurface Environments. NUREG/CR-4807, U.S. Nuclear Regulatory Commission, Washington, D.C.

Kim JJ. 1986. "Chemical Behavior of Transuranic Elements in Aquatic Systems.” In Handbook on the Physics and Chemistry of the Actinides, eds. AJ Freeman and C Keller, pp. 413-455. Elsevier Science Publishers, Amsterdam, Holland.

Kim JI, and T Sekine. 1991. "Complexation of Neptunium(V) with Humic Acid." Radiochimica. Acta. 55:187-192. 
Kim JL, DS Rhee, H Wimmer, G Buckau, and R Klenze. 1993. "Complexation of Trivalent Actinide Ions $\left(\mathrm{Am}^{3+}, \mathrm{Cm}^{3+}\right)$ with Humic Acid: A Comparison of Different Experimental Methods." Radiochimica. Acta. 62:35-43.

Kohler M, BD Honeyman, and JO Leckie. 1999. "Neptunium(V) Sorption on Hematite $\left(\alpha-\mathrm{Fe}_{2} \mathrm{O}_{3}\right)$ in Aqueous Suspension: The Effect of $\mathrm{CO}_{2}$." Radiochimica. Acta. 85:33-48.

Kokotov YA, and RF Popova. 1962. "Sorption of Long-Lived Fission Products by Soils and Argillaceous Minerals III: Selectivity of Soils and Clays toward ${ }^{90}$ Sr under Various Conditions." Soviet Radiochem. 4:292-297.

Könnecke Th., Th. Fanghänel, and JI Kim. 1997. "Thermodynamics of Trivalent Actinides in Concentrated Electrolyte Solutions: Modeling the Chloride Complexation of Cm(III)." Radiochimica. Acta. 76:131-135.

LaFlamme BD, and JW Murray. 1987. "Solid/Solution Interaction: The Effect of Carbonate Alkalinity on Adsorbed Thorium." Geochimica. et Cosmochimica. Acta. 51:243-250.

Langmuir D. 1978. "Uranium Solution-Mineral Equilibria at Low Temperatures with Applications to Sedimentary Ore Deposits." Geochimica. et Cosmochimica. Acta. 42:547-569.

Langmuir D. 1997. “Aqueous Environmental Geochemistry.” Prentice Hall, Upper Saddle River, NJ.

Langmuir D, and JS Herman. 1980. "The Mobility of Thorium in Natural Waters at Low Temperatures." Geochimica. et Cosmochimica. Acta. 44:1753-1766.

LaPlante PA, SJ Maheras, and MS Jarzemba. 1996. "Preliminary Analysis of Important SiteSpecific Dose Assessment Parameters and Exposure Pathways Applicable to a Groundwater Release Scenario at Yucca Mountain." Mat. Res. Soc. Proc. 412:897-904.

LaPlante PA, and K Poor. 1997. Information and Analyses to Support Selection of Critical Groups and Reference Biospheres for Yucca Mountain Exposure Scenarios. CNWRA 97-009. Center for Nuclear Waste Regulatory Analyses, San Antonio, TX.

Lefevre R, M Sardin, and D Schweich. 1993. "Migration of Strontium in Clayey and Calcareous Sandy Soil: Precipitation and Ion Exchange." J. Contam. Hydrol. 13:215-229.

Lemire RJ. 1984. An Assessment of the Thermodynamic Behavior of Neptunium in Water and Model Groundwater from 25 to $150^{\circ} \mathrm{C}$. AECL-7817, Atomic Energy of Canada Limited (AECL), Pinawa, Manitoba, Canada.

Lemire RJ, GD Boyer, and AB Campbell. 1993. "The Solubilities of Sodium and Potassium Dioxoneptunium(V) Carbonate Hydrates at $30^{\circ} \mathrm{C}, 50^{\circ} \mathrm{C}$, and $75^{\circ} \mathrm{C}$." Radiochimica. Acta. 61:57-63. 
Lemire RJ, J Fuger, H Nitsche, P Potter, MH Rand, J Rydbrg, K Spahiu, JC Sullivan, WJ Ullman, P Vitorge, and H Wanner. 2001. Chemical Thermodynamics 4: Chemical Thermodynamics of Neptunium and Plutonium. North-Holland, Elsevier Science Publishing Company, Inc., NY.

Lieser KH. 1993. "Technetium in the Nuclear Fuel Cycle, in Medicine and in the Environment." Radiochimica. Acta. 63:5-8.

Lieser KH, and R Hill. 1992. "Chemistry of Thorium in the Hydrosphere and in the Geosphere.” Radiochimica. Acta. 56:141-151.

Lieser KH, and U Mühlenweg. 1988. "Neptunium in the Hydrosphere and in the Geosphere. I. Chemistry of Neptunium in the Hydrosphere and Sorption of Neptunium from Groundwaters on Sediments under Aerobic and Anaerobic Conditions." Radiochimica. Acta. 44/45:129-133.

Lieser KH, and Th Steinkopff. 1989a. "Chemistry of Radioactive Cesium in the Hydrosphere and in the Geosphere." Radiochimica. Acta. 46:39-47.

Lieser KH, and Th Steinkopff. 1989b. "Chemistry of Radioactive Iodine in the Hydrosphere and in the Geosphere." Radiochimica. Acta. 46:49-55.

Lindsay WL. 1979. Chemical Equilibria in Soils. John Wiley and Sons, NY.

Lloyd JR., JA Cole, and LE Macaskie. 1997. "Reduction and Removal of Heptavalent Technetium from Solution by Escherichia coli." J. Bacteriology 179(6):2014-2021.

Lloyd JR, and LE Macaskie. 1996. "A Novel Phoshor Imager-Based Technique for Monitoring the Microbial Reduction of Technetium." Applied and Environmental Microbiology 62(2):578-582.

Lloyd JR, HF Nolting, VA Solé, K Bosecker, and LE Macaskie. 1998. "Technetium Reduction and Precipitation by Sulfate-Reducing Bacteria." Geomicrobio. J. 15:45-58.

Lloyd JR, J Ridley, T Khizniak, NN Lyalikova, and LE Macaskie. 1999. "Reduction of Technetium by Desulfovibrio desulfuricans: Biocatalyst Characterization and Use in a Flowthrough Bioreactor." Applied Environ. Microbio. 65:2691-2696.

Lloyd JR, P Yong, and LE Macaskie. 2000a. "Biological Reduction and Removal of Np(V) by Two Microorganisms.” Environ. Sci. Tech. 34:1297-1301.

Lloyd JR., VA Sole, CVG Van Praagh, and DR Lovley. 2000b. "Direct and Fe(II)-Mediated Reduction of Technetium by Fe(III)-Reducing Bacteria." Appl. Environ. Microbio. 66:37433749 . 
Losi ME, and WT Frankenberger, Jr. 1998. "Reduction of Selenium Oxyanions by Enterobacter cloacae Strain SLD1a-1." In Environmental Chemistry of Selenium, WT Frankenberger, Jr. and RA Engberg (Eds.), pp. 515-544, Marcel Dekker, Inc., New York, NY.

Lothenbach B, M Ochs, H Wanner, and M Yui. 1999. Thermodynamic Data for the Speciation and Solubility of $\mathrm{Pd}, \mathrm{Pb}, \mathrm{Sn}, \mathrm{Sb}, \mathrm{Nb}$, and Bi in Aqueous Solution. LNC TN8400 99-011, Japan Nuclear Cycle Development Institute, Ibaraki, Japan.

Lovley DR. 1993. "Dissimilatory Metal Reduction.” Annual Rev. Microbiol. 47:263-290.

Lovley DR. 1995. "Bioremediation of Organic and Metal Contaminants with Dissimilatory Metal Reduction." J. Indust. Microbio. 14:85-93.

Marquardt C, and JI Kim. 1996. "Complexation of Np(V) with Humic Acids at Very Low Metal Concentrations." Radiochimica. Acta. 73:119-125.

Marquardt C, and JI Kim. 1998. "Complexation of Np(V) with Humic Acid: Intercomparison of Results from Different Laboratories.” Radiochimica. Acta. 80:129-137.

Mattigod SV, D Rai, AR Felmy, and L Rao. 1997. "Solubility and Solubility Product of Crystalline $\mathrm{Ni}(\mathrm{OH})_{2} . "$ J. Sol. Chem. 26:391-403.

Mayland HF, LF James, KE Panter, and JL Sonderegger. 1989. "Selenium in Seleniferous Environments. In Selenium in Agriculture and the Environment, LW Jacobs (Ed.), pp. 15-50, SSSA Special Publication Number 23, Soil Science Society of America, Inc., Madison, WI.

Mazzi U. 1989. "The Coordination Chemistry of Technetium in its Intermediate Oxidation States." Polyhedron 8:1683-1688.

McNeal JM, and LS Balistrieri. 1989. "Geochemistry and Occurrence of Selenium: An Overview." In Selenium in Agriculture and the Environment, LW Jacobs (Ed.), pp. 1-13, SSSA Special Publication Number 23, Soil Science Society of America, Inc., Madison, WI.

Meyer RE, WD Arnold, and FI Case. 1984. Valence Effects on the Adsorption of Nuclides on Rocks and Minerals. NUREG/CR-3389 (ORNL-5978), prepared for the U.S. Nuclear Regulatory Commission by Oak Ridge National Laboratory, Oak Ridge, TN.

Meyer RE, WD Arnold, and FI Case. 1985. Valence Effects on the Adsorption of Nuclides on Rocks and Minerals II. NUREG/CR-4114, prepared for the U.S. Nuclear Regulatory Commission by Oak Ridge National Laboratory, Oak Ridge, TN.

Morel FMM. 1983. Principles of Aquatic Chemistry. John Wiley and Sons, NY.

Moulin V, P Robouch, P Vitorge, and B Allard. 1988. "Environmental Behavior of Americium(III) in Natural Waters." Radiochimica. Acta. 44/45:33-37. 
Moulin V, J Tits, and G Ouzounian. 1992. "Actinide Speciation in the Presence of Humic Substances in Natural Water Conditions.” Radiochimica. Acta. 58/59:179-190.

Muramatsu Y, S Uchida, P Sriyotha, and K Sriyotha. 1990. "Some Considerations on the Sorption and Desorption Phenomena of Iodide and Iodate on Soil." Water, Air, and Soil Pollution 49:125-138.

Nachtegaal M, and DL Sparks. 2003. "Nickel Sequestration in a Kaolinite-Humic Acid Complex." Environ. Sci. Tech. 37:529-534.

Nakayama S, T Yamaguchi, and K Sekine. 1996. "Solubility of Neptunium(IV) Hydrous Oxide in Aqueous Solutions." Radiochimica. Acta. 74:15-19.

National Academy of Sciences (NAS). 1976. Selenium. Medical and Biologic Effects of Environmental Pollutants. Washington, D.C.

Nash K, S Fried, AM Freidman, and JC Sullivan. 1981. "Redox Behavior, Complexing, and Adsorption of Hexavalent Actinides by Humic Acid and Selected Clays." Environ. Sci. Tech. 15:834-837.

Neck V, W Runde, JI Kim, and B Kandellakopulos. 1994. "Solid-Liquid Equilibrium Reactions of Neptunium(V) in Carbonate Solution at Different Ionic Strength." Radiochimica. Acta. 65:29-37.

Nelson DM, RP Larson, and WR Penrose. 1987. "Chemical Speciation of Plutonium in Natural Waters." In Environmental Research on Actinide Elements, eds. JE Pinder, JJ Alberts, KW McLeod, and RG Schreckhise, pp. 27-48. CONF-841142 (DE86008713), Office of Scientific and Technical Information, U.S. Department of Energy, Washington, D.C.

Nelson DM, and MB Lovett. 1980. "Measurements of the Oxidation State and Concentration of Plutonium in Interstitial Waters in the Irish Sea." In Impacts of Radionuclide Releases Into the Marine Environment, IAEA ed. Staff, pp. 105-118. International Atomic Energy Agency (IAEA), Vienna, Austria.

Nelson DM, and KA Orlandini. 1979. Identification of $P u(V)$ in Natural Waters. ANL-79-65, Argonne National Laboratory, Argonne, IL.

Nelson DC, WH Casey, JD Sison, EE Mack, A Ahmad, and JS Pollack. 1996. "Selenium Uptake by Sulfur-Accumulating Bacteria." Geochim. Cosmo. Acta 60:3531-3539.

Nordstrom DK, and JL Munoz. 1985. Geochemical Thermodynamics. The Benjamin/Cummings Publishing Co., Inc., Menlo Park, CA.

Novak CF, and KE Roberts. 1995. "Thermodynamic Modeling of Neptunium(V) Solubility in Concentrated $\mathrm{Na}-\mathrm{CO}_{3}-\mathrm{HCO}_{3}-\mathrm{Cl}-\mathrm{ClO}_{4}-\mathrm{H}-\mathrm{OH}-\mathrm{H}_{2} \mathrm{O}$ Systems." In Scientific Basis for Nuclear 
Waste Management XVIII, eds.T Murakami and RC Ewing, Materials Research Society Symposium Proceedings, vol. 353, pp. 1119-1128. Materials Research Society, Pittsburgh, PA.

Nriagu JO (Ed.). 1980. Nickel in the Environment. John Wiley and Sons, New York, NY.

Onishi Y, RJ Serne, EM Arnold, and C E Cowan, and FL Thompson. 1981. Critical Review: Radionuclide Transport, Sediment Transport, and Water Quality Mathematical Modeling; and Radionuclide Adsorption/Desorption Mechanisms. NUREG/CR-1322 (PNL-2901) prepared for the U.S. Nuclear Regulatory Commission, Washington, D.C. by Pacific Northwest Laboratory, Richland, WA.

Östhols E, J Bruno, and I Grenthe. 1994. "On the Influence of Carbonate on Mineral Dissolution: III. The Solubility of Microcrystalline $\mathrm{ThO}_{2}$ in $\mathrm{CO}_{2}-\mathrm{H}_{2} \mathrm{O}$ Media." Geochimica. et Cosmochimica. Acta. 58:613-623.

Panak P, R Klenze, and JI Kim. 1996. "A Study of Ternary Complexes of Cm(III) with Humic Acid and Hydroxide or Carbonate in Neutral pH Range by Time-Resolved Laser Fluorescence Spectroscopy." Radiochimica. Acta. 74:141-146.

Paquette J, and WE Lawrence. 1985. "A Spectroelectrochemical Study of the Technetium(IV)/Technetium(III) Couple in Bicarbonate Solutions.” Canadian J. Chem. 63:2369-2373.

Paviet P, Th. Fanghänel, R Klenze, and JI Kim. 1996. "Thermodynamics of Curium(III) in Concentration Electrolyte Solutions: Formation of Sulfate Complexes in $\mathrm{NaCl} / \mathrm{Na}_{2} \mathrm{SO}_{4}$ Solutions." Radiochimica. Acta. 74:99-103.

Penrose WR, WL Polzer, EH Essington, DM Nelson, and KA Orlandini. 1990. "Mobility of Plutonium and Americium through a Shallow Aquifer in a Semiarid Region." Environ. Sci. Tech. 24:228-234.

Phillips SL, FV Hale, LF Silvester, and MD Siegel. 1988. Thermodynamic Tables for Nuclear Waste Isolation. NUREG/CR-4864 (also listed as LBL-22860 and SAND87-0323), U.S. Nuclear Regulatory Commission, Washington, D.C.

Poole SC, and E Porter. 1999. "Selenium (IV) Reduction by Bacillus and Desulfovibrio in the Presence of Iron (II, III)." In Wetlands and Remediation, JL Means and RE. Hinchee (Eds.), pp. 431-438, Battelle Press, Columbus, OH.

Rai D, JM Zachara, AP Schwab, RL Schmidt, DC Girvin, and JE Rogers. 1984. Chemical Attenuation Rates, Coefficients, and Constants in Leachate Migration. Volume 1: A Critical Review. EA-3356, Electric Power Research Institute, Palo Alto, CA.

Rai D, AR Felmy, DA Moore, and MJ Mason. 1995. "The Solubility of Th(IV) and U(IV) Hydrous Oxides in Concentrated $\mathrm{NaHCO}_{3}$ and $\mathrm{Na}_{2} \mathrm{CO}_{3}$ Solutions." In Scientific Basis for Nuclear Waste Management XVIII, Part 2, eds. T Murakami and RC Ewing, Materials Research 
Society Symposium Proceedings, vol. 353, pp. 1143-1150. Materials Research Society, Pittsburgh, PA.

Rai D, NJ Hess, AR Felmy, DA Moore, and M Yui. 1999. "A Thermodynamic Model for the Solubility of $\mathrm{NpO}_{2}(\mathrm{am})$ in the Aqueous $\mathrm{K}^{+}-\mathrm{HCO}_{3}{ }^{-}-\mathrm{CO}_{3}{ }^{2-}-\mathrm{OH}^{-}-\mathrm{H}_{2} \mathrm{O}$ System." Radiochimica. Acta. 84:159-169.

Rai D, and JL Ryan. 1985. "Neptunium(IV) Hydrous Oxide Solubility Under Reducing and Carbonate Conditions." Inorg. Chem. 24:247-251.

Rai D, RJ Serne, and DA Moore. 1980a. "Solubility of Plutonium Compounds and Their Behavior in Soils." Soil Sci. Soc. America J. 44:490-495.

Rai D, RJ Serne, and JL Swanson. 1980b. "Solution Species of Plutonium in the Environment." J. Environ. Quality 9:417-420.

Rai D, JL Swanson, and JL Ryan. 1987. "Solubility of $\mathrm{NpO}_{2} \cdot \mathrm{xH}_{2} \mathrm{O}(\mathrm{am})$ in the Presence of $\mathrm{Cu}(\mathrm{I}) / \mathrm{Cu}(\mathrm{II})$ Redox Buffer.” Radiochimica. Acta. 42:35-41.

Rao L, and GR Choppin. 1995. "Thermodynamic Study of the Complexation of Neptunium(V) with Humic Acids." Radiochimica. Acta. 69:87-95.

Rard JA, MH Rand, G Anderegg, and H Wanner. 1999. "Chemical Thermodynamics 3:

Chemical Thermodynamics of Technetium," eds. MCA Sandino and E Östhols. North-Holland, Elsevier Science Publishing Company, Inc., NY.

Read D, TA Lawless, RJ Sims, and KR Butter. 1993. "Uranium Migration through Intact Sandstone Cores." J. Contam. Hydrol. 13:277-289.

Rhodes DW. 1957. "The Effect of $\mathrm{pH}$ on the Uptake of Radioactive Isotopes from Solution by a Soil.” Soil Sci. Soc. America Pro. 21:389-392.

Richter RO, and TL Theis. 1980. "Nickel Speciation in a Soil/Water System." In Nickel in the Environment, J. O. Nriagu (Ed.), pp. 189-202, John Wiley and Sons, New York, NY.

Roberts KE, HB Silber, PC Torretto, T Prussin, K Becraft, DE Hobart, and CF Novak. 1996. "The Experimental Determination of the Solubility Product for $\mathrm{NpO}_{2} \mathrm{OH}$ in $\mathrm{NaCl}$ Solutions." Radiochimica. Acta. 74:27-30.

Robertson DE, CW Thomas, SL Pratt, EA Lepel, VW Thomas. 2000. Low-Level Radioactive Waste Classification, Characterization, and Assessment: Waste Streams and Neutron-Activated Metals. NUREG/CR-6567, PNNL-11659, U.S. Nuclear Regulatory Commission, Washington, D.C. 
Routson RC, GS Barney, and RM Smith. 1980. Hanford Site Sorption Studies for the Control of Radioactive Wastes: A Review. WHO-SA-155, Rev. 1, Rockwell Hanford Operations, Richland, WA.

Ryan JL, and D Rai. 1987. "Thorium(IV) Hydrous Oxide Solubility." Inorgan. Chem. 26:4140-4142.

Sakamoto Y, S Nagao, H Ogawa, and RR Rao. 2000. “The Migration Behavior of Np(V) in Sandy Soil and Granite Media in the Presence of Humic Substances." Radiochimica. Acta. 88:651-656.

Sanchez AL, JW Murray, and TH Sibley. 1985. "The Adsorption of Pu(IV) and (V) of Goethite." Geochimica. et Cosmochimica. Acta. 49:2297-2307.

Sandino A, and J Bruno. 1992. "The Solubility of $\left(\mathrm{UO}_{2}\right)_{3}\left(\mathrm{PO}_{4}\right)_{2} \cdot 4 \mathrm{H}_{2} \mathrm{O}(\mathrm{s})$ and the Formation of U(VI) Phosphate Complexes: Their Influence in Uranium Speciation in Natural Waters." Geochimica. et Cosmochimica. Acta. 56:4135-4145.

Scheckel KG, and DL Sparks. 2000. "Kinetics of the Formation and Dissolution of Ni Precipitates in a Gibbsite/Amorphous Silica Mixture.” J. Coll. Inter. Sci. 229:222-229.

Scheckel KG, and DL Sparks. 2001. "Temperature Effects on Nickel Sorption Kinetics at the Mineral-Water Interface." Soil Sci. Soc. America J. 65:719-728.

Schulz RK. 1965. "Soil Chemistry of Radionuclides.” Health Physics 11:1317-1324.

Schwertmann U and RM Taylor. 1989. "Iron Oxides.” In Minerals in Soil Environments, Second Edition, eds. JB Dixon and SB Week, pp. 379-438. Soil Science Society of America, Madison, Wisconsin.

Séby F, M Potin-Gautier, E Giffaut, and OFX Donard. 2001. "A Critical Review of Thermodynamic Data for Inorganic Tin Species.” Geochim. Cosmo. Acta 65:3041-3053.

Serne RJ, JL Conca, VL LeGore, KJ Cantrell, CW Lindenmeier, JA Campbell, JE Amonette, and MI Wood. 1993. Solid Waste Leach Characteristics and Contaminant Sediment Interactions. Volume 1: Batch Leach and Adsorption Tests and Sediment Characterization. PNL-8889, Pacific Northwest Laboratory, Richland, WA.

Shanbhag PM, and GR Choppin. 1981. "Binding of Uranyl by Humic Acid." J. Inorg. Nucl. Chem. 43:3369-3372.

Sheppard JC, MJ Campbell, JA Kittrick, and TL Hardt. 1979. "Retention of Neptunium, Americium, and Curium by Diffusible Soil Particles.” Environ. Sci. Tech. 13:680-684.

Sheppard MI, and DH Thibault. 1988. "Migration of Technetium, Iodine, Neptunium, and Uranium in the Peat of Two Minerotrophic Mires.” J. Environ. Quality 17:644-653. 
Sheppard MI, and DH Thibault. 1990. "Default Soil Solid/Liquid Partition Coefficients, $\mathrm{K}_{\mathrm{d}} \mathrm{s}$, for Four Major Soil Types: A Compendium.” Health Physics 59(4):471-482.

Shin HS, BH Lee, JG Choi, and H Moon. 1995. "Complexation of Soil Humic Acid with Trivalent Curium and Europium Ions: A Comparative Study.” Radiochimica. Acta. 69:185-189.

Silva RJ. 1984. "The Behavior of Americium in Aqueous Carbonate Systems." In Scientific Basis for Nuclear Waste Management VII, ed. GL McVay, vol. 26, pp. 875-881. Materials Research Society Symposium Proceedings. North-Holland, NY.

Silva RJ, G Bidoglio, MH Rand, PB Robouch, H Wanner, and I Puigdomenech. 1995. Chemical Thermodynamics 2: Chemical Thermodynamics of Americium. North-Holland, Elsevier Science Publishing Company, Inc., NY.

Silva RJ, and H Nitsche. 1995. "Actinide Environmental Chemistry." Radiochimica. Acta. 70/71:377-396.

Silver GL. 1983. "Comment on the Behavior of the Chemical Forms of Plutonium in Seawater and Other Aqueous Solutions.” Marine Chemistry 12:91-96.

Skogerboe RK, and SA Wilson. 1981. "Reduction of Ionic Species by Fulvic Acid." Analytical Chemistry 53:228-232.

Smith IC, and BL Carson. 1977. Trace Metals in the Environment. Volume 2 - Silver. Ann Arbor Science Publishers, Inc., Ann Arbor, MI.

Snodgrass WJ. 1980. "Distribution and Behavior of Nickel in the Aquatic Environment." In Nickel in the Environment, J. O. Nriagu (Ed.), pp. 203-274, John Wiley and Sons, New York, NY.

Sparks ST, and SE Long. 1987. The Chemical Speciation of Technetium in the Environment: A Literature Study. DOE/RW 88.098 (UKAEA/DOE Radiological Protection Research Programme Letter AERE-R 12743), Harwell Laboratory, Oxfordshire, England.

Sposito G. 1994. Chemical Equilibria and Kinetics in Soils. Oxford University Press, NY.

Sposito G. 1989. The Chemistry of Soils. Oxford University Press, NY.

Strenge DL and SR Peterson. 1989. Chemical Databases for the Multimedia Environmental Pollutant Assessment System. PNL-7145, Pacific Northwest Laboratory, Richland, WA.

Stumm W, and JJ Morgan. 1981. Aquatic Chemistry. An Introduction Emphasizing Chemical Equilibria in Natural Waters. John Wiley and Sons, NY. 
Susak NJ, A Friedman, S Fried, and JC Sullivan. 1983. "The Reduction of Neptunium(VI) by Basalt and Olivine." Nucl. Tech. 63:266-270.

Suzuki Y and JF Banfield. 1999. "Geomicrobiology of Uranium.” In Uranium: Mineralogy, Geochemistry and the Environment. Reviews in Mineralogy, eds. PC Burns and R Finch, vol. 38, pp. 393-432. Mineralogical Society of America, Washington, D.C.

Tait CD, SA Ekberg, PD Palmer, and DE Morris. 1995. Plutonium Carbonate Speciation Changes as Measured in Dilute Solutions with Photoacoustic Spectroscopy. LA-12886-MS, Los Alamos National Laboratory, Los Alamos, NM.

Tanaka S, M Yamawaki, S Nagasaki, and H Moriyama. 1992. "Geochemical Behavior of Neptunium.” J. Nucl. Sci. Tech. 29:706-718.

Thibault DH, MI Sheppard, and PA Smith. 1990. A Critical Compilation and Review of Default Soil Solid/Liquid Partition Coefficients, $K_{d}$, for Use in Environmental Assessments.

AECL-10125, Whiteshell Nuclear Research Establishment, Atomic Energy of Canada Limited, Pinawa, Canada.

Thompson RC. 1982. "Neptunium: The Neglected Actinide: A Review of the Biological and Environmental Literature." Rad. Res. 90:1-32.

U.S. Environmental Protection Agency (EPA). 1999a. Understanding Variation in Partition Coefficient, $K_{d}$,Values: Volume I. The $K_{d}$ Model, Methods of Measurement, and Application of Chemical Reaction Codes. EPA 402-R-99-004A, U.S. Environmental Protection Agency, Washington, D.C., prepared by KM Krupka, DI Kaplan, G Whelan, RJ Serne, and SV Mattigod at the Pacific Northwest National Laboratory, Richland, WA.

U.S. Environmental Protection Agency (EPA). 1999b. Understanding Variation in Partition Coefficient, $K_{d}$,Values: Volume II. Review of Geochemistry and Available $K_{d}$ Values for Cadmium, Cesium, Chromium, Lead, Plutonium, Radon, Strontium, Thorium, Tritium ( $\left.{ }^{3} H\right)$, and Uranium. EPA 402-R-99-004B, prepared for the U.S. Environmental Protection Agency, Washington, D.C. by the Pacific Northwest National Laboratory, Richland, WA.

Veizer J. 1983. "Trace Elements and Isotopes in Sedimentary Carbonates." In Carbonates: Mineralogy and Chemistry, ed. RJ Reeder, vol. 11, pp. 265-299. Reviews in Mineralogy, Mineralogical Society of America, Washington, D.C.

Veselý J, SA Norton, P Skřivan, V Majer, P Krám, T Navrátil, and JM Kaste. 2002. "Environmental Chemistry of Beryllium." In Beryllium: Mineralogy, Petrology, and Geochemistry. Reviews in Mineralogy and Geochemistry. Volume 50, E. S. Grew (Ed.), pp. 291-317, Mineralogical Society of America, Washington, D.C.

Vitorge P. 1992. " $\mathrm{Am}(\mathrm{OH})_{3(\mathrm{~s})}, \mathrm{AmOHCO}_{3(\mathrm{~s})}, \mathrm{Am}_{2}\left(\mathrm{CO}_{3}\right)_{3(\mathrm{~s})}$ Stabilities in Environmental Conditions." Radiochimica. Acta., 58/59:105-107. 
Wagman DD, WH Evans, VB Parker, RH Shumm, I Halow, SM Bailey, KL Churney, and RL Nuttall. 1982. "The NBS Tables of Chemical Thermodynamic Properties. Selected Values for Inorganic and $\mathrm{C}_{1}$ and $\mathrm{C}_{2}$ Organic Substances in SI Units." J. Phys. Chem. Ref. Data 11 Supplement No. 2:1-392.

Waite TD, JA Davis, TE Payne, GA Waychunas, and N Xu. 1994. "Uranium(VI) Adsorption to Ferrihydrite: Application of a Surface Complexation Model.” Geochimica. et Cosmochimica. Acta. 58(24):5465-5478.

Wescott RG, MP Lee, NA Eisenberg, TJ McCartin, and RG Baca. 1995. NRC Iterative Performance Assessment Phase 2. Development of Capabilities for Review of a Performance Assessment for a High-Level Waste Repository. NUREG-1464. Nuclear Regulatory Commission, Washington, D.C.

Wharton MJ, B Atkins, JM Charnock, FR Livens, RAD Pattrick, and D Collison. 2000. “An X-ray Absorption Spectroscopy Study of the Coprecipitation of Tc and Re with Mackinawite (FeS)." Appl. Geochem. 15:347-354.

White AF. 1990. "Heterogeneous Electrochemical Reactions Associated with Oxidation of Ferrous Oxide and Silicate Surfaces." In Reviews in Mineralogy, Mineral-Water Interface Geochemistry, eds. MF Hochella, Jr., and AF White, vol. 23, pp. 467-509. Mineralogical Society of America, Washington, D.C.

Whitehead DC. 1984. "The Distribution and Transformation of Iodine in the Environment." Environ. Internat. 10:321-339.

Whitehead DC. 1974. "The Influence of Organic Matter, Chalk, and Sesquioxides on the Solubility of Iodide, Element Iodine, and Iodate Incubated with Soil.” J. Soil Sci. 25:461-470.

Wildung RE, YA Gorby, KM Krupka, NJ Hess, SW Li, AE Plymale, JP McKinley, and JK Fredrickson. 2000. "Effect of Electron Donor and Solution Chemistry on the Products of the Dissimilatory Reduction of Technetium by Shewanella putrefaciens." Appl. Environ. Microbio. 66:2452-2460.

Wildung RE, KM McFadden, and TR Garland. 1979. "Technetium Sources and Behavior in the Environment." J. Environmen. Quality 8:156-161.

Wildung RE, RC Routson, RJ Serne, and TR Garland. 1974. "Pertechnetate, Iodide and Methyl Iodide Retention by Surface Soils." In Pacific Northwest Laboratory Annual Report for 1974 to the USAEC Division of Biomedical and Environmental Research. Part 2. Ecological Sciences, BE Vaughan (manager), pp. 37-40. BNWL-1950 PT2, Pacific Northwest Laboratories, Richland, WA.

Wilson ML, PN Swift, JA McNeish, and SD Sevougian. 2002. "Total-System Performance Assessment for the Yucca Mountain Site.” Mat. Res. Soc. Proc. 713:153-164. 
Wimmer H, JI Kim, and R Klenze. 1992. "A Direct Speciation of Cm(III) in Natural Aquatic Systems by Time-Resolved Laser-Induced Fluorescence Spectroscopy (TRLFS).”

Radiochimica. Acta. 58/59:165-171.

Yamaguchi T, Y Sakamoto, and T Ohnuki. 1994. "Effect of the Complexation on Solubility of $\mathrm{Pu}(\mathrm{IV})$ in Aqueous Carbonate System.” Radiochimica. Acta. 66/67:9-14.

Yariv S, and H Cross. 1979. Geochemistry of Colloid Systems for Earth Scientists. SpringerVerlag, New York, NY.

You C-F, T Lee, and YH Li. 1989. "The Partition of Be between Soil and Water." Chem. Geol. 77:105-118.

You C-F, JD Morris, JM Gieskes, R Rosenbauer, SH Zheng, X Xu, T L Ku, and LJ Bischoff. 1994. "Mobilization of Beryllium in the Sedimentary Column at Convergent Margins."

Geochim. Cosmo. Acta 58:4887-4897.

Yu Z, JA Warner, RA Dahlgren, and WH Casey. 1996. "Reactivity of Iodide in Volcanic Soils and Noncrystalline Soil Constituents." Geochimica et Cosmochimica 60:4945-4956.

Zeh P, JI Kim, CM Marquardt, and R Artinger. 1999. "The Reduction of Np(V) in Groundwater Rich in Humic Substances." Radiochimica. Acta. 87:23-28.

Zhang YQ, WT Frankenberger, Jr, and JN Moore. 1999. "Effect of Soil Moisture on Dimethylselenide Transport and Transformation to Nonvolatile Selenide." Environ. Sci. Tech. 33:3415-3420.

Zhang YQ, and WT Frankenberger, Jr. 2000. "Formation of Dimethylselenonium Compounds in Soil." Environ. Sci. Tech. 34:776-783. 


\subsection{Uptake of Radionuclides by Plants}

\subsection{Objective and Approach}

The importance of the terrestrial plant in intercepting and/or absorbing radionuclides derived from components of the nuclear fuel cycle and its waste streams stems from the potential for plants to be a major contributor to human health impacts through both direct ingestion and/or indirect transfers via the food chain. While data for all radionuclides are not available, it should be noted that reasonable assessments of an isotope's behavior can be gleaned from the behavior and natural flow through the environment of the stable species and in many cases their chemical analogues. Thus, the objective of this literature review is to summarize the pertinent available literature for specific radionuclides, including chemical analogues where necessary, and to attempt to rationalize the normal variability imposed by both physicochemical and biotic processes on bioavailability and speciation, and thus their overall behavior with respect to risk. Emphasis will be limited to terrestrial systems; specifically, source terms will include soils, and where possible, irrigation waters and catastrophic geological events.

The approach will attempt to avoid use of data sources where the experimental design leaves questions as to source-term characteristics, where cultivation conditions limit normal plant operation, or where the route of exposure is complicated, i.e., soil with an airborne/foliar interception component. We also attempted to identify those radionuclides that may, due to their chemical analogue nature, be undergoing significant chemical alteration/complexation/bioincorporation, and thus may represent a potential added risk factor beyond the current numerical transfer factor.

\subsection{Process Constraints}

A significant basis for the variability in existing transfer factors for plants results from several basic factors. These include:

1. The physicochemical characteristics of the element or radionuclide; for example, the contaminant source is a refractory form or a species able to undergo chemical transformations, i.e., increased solubilization, within less than geological time.

2. The routes of exposure, including soil/groundwater, groundwater/irrigation/foliage, and atmospheric transport to foliage.

3. Natural biological variables that affect transfer.

4. The relationship between contaminant chemical form and potential for speciation, and the interactions with biotic processes that further influence chemical speciation and form. In the simplest of terms, potential risk results from a balance between the chemical nature of a radionuclide and how a plant normally copes with this type of compound, e.g., oxide, carbonate, or ion, e.g., charge, valence. 


\subsubsection{Contaminant Form and Chemistry}

The nuclear fuel cycle and its waste streams are composed of two extremes. These include:

1. The highly refractory oxides/carbonates are represented by many of the actinide series and other elements. These tend to have extremely low solubility constants/rates in normal natural environments (Eh, $\mathrm{pH}$ ), and exist primarily in the particulate state due to the nature of many waste streams, and/or when released to the environment.

2. The activation and fission products, which include transition elements and others, are at the other extreme. These elements are generally characterized by their capability to be readily solubilized under normal environmental conditions, and/or undergo redox to form other stable forms.

From the standpoint of the transfer of radionucldes from soil, water, or air to plants and the balance of the food chain, we are dealing with a continuum of predictable chemical reactions/speciation that begins with the waste formand is altered within the transport routes within the environment with rates that vary widely with initial form and subsequent physicochemical potentials. It is this equilibrium behavior that determines whether a particular ion or compound form is bioavailable.

Taking the two extremes once again, we can make several generalities that will be applicable to the biotic transfer question. For refractory materials, i.e., fuel-rod material and nuclear-defense wastes or materials, the starting forms are usually oxides. These are degraded/altered somewhat during use or processing, but remain basically refractory oxides and are represented by various elements of the actinide series. The chemistry of these elements is very predictable under most conditions, and thus the transport forms would be either oxides (particles), or carbonates; but in most cases, all will have low solubilities over geological time or under usual chemical environments. For process waste forms, these radionuclides can form stable species, including hydroxides, carbonates, and others, which can increase their solubilization kinetics. Of these, plutonium, thorium, and americium would be expected to have the most stable oxide/hydroxide forms and very low solubility rates. Neptunium, and possibly curium, have exhibited slightly higher biotic transfer rates, likely due to their dominant oxidation states and solubilities. Uranium has probably the widest demonstrated range in bioavailability. This is likely due to difficulties in predicting and/or controlling speciation because uranium can not only form a range of cationic species, but also anionic species.

The fission and activation products present the opposite extreme. These represent a series of ions that can exist either in the cationic and/or anionic state. Elements such as $\mathrm{Cs}, \mathrm{Sr}, \mathrm{Ni}, \mathrm{Sn}, \mathrm{Se}$, I, and Ag have natural stable analogues for which physicochemcial behavior can be predicted. Little data are available for elements such as silver, beryllium, and niobium. From a risk standpoint (food chain), elements such as technetium, selenium, and iodine that can form stable anions under environmental conditions can be problematic due to both increased mobility and bioavailability. 


\subsubsection{Routes of Exposure}

For our purposes, we need to assume a source location/characteristic (e.g., repository, event), and determine risk factors based on an uncontrolled release of radionuclides to groundwater and/or air. In the event of radionuclides being released to ground waters/geological matrices from a repository, the original waste form, if not the geological time frame, will determine the dominant chemical form. In the case of fuels/particulate wastes, actinide oxides will likely remain as oxides or form hydroxides at some rate. In the case of process wastes, where actinides are in a somewhat soluble form (e.g., nitrates, organic complexes), radionuclides will likely form alternate chemical species on contact with geological components. Similarly, fission products and activation products contained within refractory waste forms, e.g., fuels, may or may not have stable chemical forms. However, once released to geological media, the original chemical form and the physicochemical environment will permit stable speciation of these elements. For example, species (technetium, selenium, iodine) that can readily form anions at environmental $\mathrm{pH} /$ Eh regimes will be more mobile in geological matrices, and in many cases more plantavailable. Elements such as $\mathrm{Ni}, \mathrm{Cs}, \mathrm{Sr}, \mathrm{Ag}, \mathrm{Sn}$, and $\mathrm{Nb}$ will likely remain cationic and form stable compounds that affect both mobility and bioavailability. The entire process of speciation and chemical behavior can be repeated when the geological matrices change, such as entry into surface soils.

Vulcanism and related processes can represent a mechanism for massive disruption of waste containment and redistribution. While there are many scenarios, in general, there can be atmospheric releases of either volatile elemental forms, release of particulate refractory forms, and/or steam-carried species. This provides a secondary exposure route through aerial deposition.

For both failure scenarios, aerial deposition can represent a secondary route to the food chain via plant interception. In the case of groundwater sources, radionuclides can come into contact with plants through groundwater/surface soil interaction, irrigation processes, or in the case of aerial releases, through direct deposition to soils and plant canopies and subsequent mobilization via irrigation or precipitation events.

\subsubsection{Biological Variables}

The biological variables inherent in plants as well as other biological forms are the likely source of much of the variability in transfer factors. The basis of this variability centers in (1) the chemical nature/speciation of the radionuclide with which the plant encounters, (2) the nature of these chemical species with respect to the capacity of metabolic and biochemical mechanisms present for normal management of essential ions, and (3) detoxification mechanisms.

Terrestrial plants, as sessile organisms, have adapted to derive essential nutrients from their environments. They also can adapt to chemical/toxic environments by employing protective mechanisms. For radionuclides that are, in fact, nutrient ions, i.e., nickel, selenium, and iodine, biochemical mechanisms are in place to absorb and chemically process them. In some cases, radionuclides can represent chemical analogues of essential elements, i.e., $\mathrm{Tc} / \mathrm{S}, \mathrm{Sr} / \mathrm{Ca}$, and 
$\mathrm{Cs} / \mathrm{K}$, and in these cases, they are absorbed and processed in a manner analogous to their natural analogues.

In the case of most radionuclides, where there appears to be no analogue behavior and are viewed by the plant as harmful species, two processes have evolved over the evolutionary time scale to detoxify or protect the plant. The first and most common is immobilization in or on the outer root cell wall materials, and/or root secretions to immobilize toxic elements within the soil/rhizosphere. This basically limits plant/biochemical disruption, and this mechanism may be operational for most of the actinides. The second involves actual plant absorption and involves a secondary series of responses to either detoxify through chemical complexation and/or compartmentalization/sequestration. This can involve, for many ions, a significant application of the plants' inherent capability to engage in oxidation and/or reduction reactions. In this case, common "heavy metals/elements" needed by the plant but in excess, e.g., Ni, Se, Cr, W, Co, Mo, $\mathrm{Mn}, \mathrm{Fe}, \mathrm{Cu}, \mathrm{Zn}$, or analogues to essential nutrients, e.g., Tc, V, Cr, Cd, Sn, and As, can be processed by normal biochemical/metabolic methods.

Additionally, individual plant genera, and in many cases species/cultivars, have adapted to specific environs and toxicant loads, resulting in evolution/selection of plant traits (100s to 1000s years) referred to as tolerant or accumulators (protection by external exclusion or internal complexation/sequestration/detoxification). Thus, much of the variability seen in transfer factors for radionuclides and stable elements is due to these plant factors.

\subsubsection{Role of Speciation and Chemical Form/Transfer Factors and Food Chain}

It is clear from the wealth of radionuclide transfer data, and plant metabolic studies, that all of the above variables affect transfer and thus the extent of food-chain risk. Of specific interest in understanding transfer is the nature of the radionuclide, its chemical stability with respect to speciation, its possible analogue behavior, and the varying potential of individual plant genera/species. It is also clear that for many radionuclides, plant-induced changes to speciation and subsequent complexation may in fact increase the flow and impacts to higher trophic levels in the food chain.

\subsection{Soil-to-Plant Transfer}

The following review of soil/plant transfer ratios attempts to review relevant studies where there is reasonable expectation of source-term chemistry and concentration, soil characteristics, plant parameters, and the relevance to published transfer values employed in modeling (IAEA 1994). Elements/isotopes to be considered include: ${ }^{90} \mathrm{Sr}$ and ${ }^{137} \mathrm{Cs}$ as reference points, and ${ }^{99} \mathrm{Tc},{ }^{129} \mathrm{I}$, ${ }^{121} \mathrm{Sn},{ }^{79} \mathrm{Se},{ }^{232} \mathrm{Th},{ }^{235} \mathrm{U},{ }^{239} \mathrm{Pu},{ }^{237} \mathrm{~Np},{ }^{241} \mathrm{Am},{ }^{242} \mathrm{Cm},{ }^{10} \mathrm{Be},{ }^{59 / 63} \mathrm{Ni},{ }^{94} \mathrm{Nb}$, and ${ }^{108 \mathrm{~m}} \mathrm{Ag}$.

It should be noted that concentration ratios (CRs) for soil-to-plant reflect the summation of a complex series of factors, both physicochemical and biotic. The physicochemical factors include: 
1. the nature of the source term, refractory, molecular form associated with soluble/mixed waste streams, and kinetics to undergo new states/speciation based on environmental $\mathrm{pH} / \mathrm{Eh}$, and presence of appropriate counter-ions

2. the chemical nature of the geological matrices in which it is transported or deposited; this includes the chemical/mineral nature of subsurface channels, groundwaters, and soil

3. the route by which the terrestrial pant is exposed (soil, irrigation waters, aerial deposition of particles, or aerial deposition of gaseous forms.

Biotic factors are likely the source of most of the variability seen in CRs. This results from the nature of the sessile terrestrial plant and its relationship with its environment. This centers on the need to compete and acquire specific nutrient species from soils, and the need of individual plant types for specific levels of individual nutrients. Thus, the CR value is affected by the following biotic factors:

1. the plant available concentration in soils within the rhizosphere, which is governed by soil adsorption processes, chemical solubility, and stability of the chemical complexes

2. the chemical nature and stability of the cation-anion/complex with respect to the plant's capability to metabolically alter and/or absorb the elemental form into the plant

3. a series of plant adaptive/evolutionary processes for survival; this can include, but not be limited to, protective root processes (exclusion or complexation of an ion for detoxification, sequestration within the plant to regulate both ion levels and for detoxification, redox to alter solubility and transport when necessary, organic complexation in the case of all but monocationic elements, and uptake capacity being dependent on metabolic needs.

Under these chemical and biotic constraints, CR values can be expected to vary based on source term, kinetics of solubilization/speciation, the relative ability of a plant to view a non-nutrient ion as an analogue to a nutrient species, and the relative need by the individual plant genus/species for specific levels of a particular ion. The following overview and assessment of data needs is presented in this light.

\subsubsection{Cesium}

Environmental/Soil Behavior. Cesium exists in the environment in the 1+ oxidation state. Stable cesium is ubiquitous in the environment with a crustal abundance of approximately 3.2 $\mathrm{mg} / \mathrm{kg}$; in soils, cesium concentrations range between 0.3 and $25 \mathrm{mg} / \mathrm{kg}$ (Lindsay 1979). The dominant aqueous species in soil and aquatic systems is thought to be the free $\mathrm{Cs}+$ species. The $\mathrm{Cs}+$ ion forms only extremely weak aqueous complexes with $\mathrm{SO}_{4}{ }^{-2}, \mathrm{Cl}^{-}$, and $\mathrm{NO}_{3}{ }^{-}$, and therefore the formation of inorganic complexes is not believed to be a major influence on cesium speciation (Bovard et al. 1968). Further, the complexation of cesium by chelates, such as EDTA, is believed to be poor because of the generally low stability of cesium chelates and the presence of other elements, such as calcium, at significantly higher concentrations than cesium. Therefore, aqueous speciation and complexation is not thought to greatly influence cesium behavior in the natural environment. Neither precipitation nor coprecipitation are expected to 
affect cesium aqueous concentrations or its mobility in soils. Sorption of cesium to organic colloids should follow a relationship similar to that of dissolved organic humic materials and should therefore not be an important sink for cesium in most soils. It has been frequently demonstrated that cesium becomes associated with the clay mineral fraction of soils. The association of cesium with clay minerals is characterized by high selectivity.

Cesium Concentration Ratios. Cesium uptake from soil by a single crop is less than $0.1 \%$ of the soil's content (Menzel 1963). Prairie grasses concentrate cesium by factors of 0.02 to 5.0, depending on soil conditions and grass species (Schuller et al. 1993). On the basis of Menzel's classification of concentration factors of elements in plants, cesium is considered "slightly excluded" (Menzel 1963). Concentration ratios for emergent seed plants range from 50 to 600 . On the other hand, Voight et al. (1991) reported root-transfer factors for ${ }^{137} \mathrm{Cs}$ of 0.002 for grains, 0.002 for potatoes, 0.0047 for lettuce, and 0.003 for bush beans. Garland et al. (1983) found concentration factors of 3E-3 for tumble mustard and 0.5 for cottonwood and willow leaves.

A review/tabulation of CR values for cesium is far ranging based on the controlling factors described above and as delineated by environment and plant type in Table 3.1. For growth chamber and greenhouse studies, CR values for cesium can be assumed to be high due to cultivation pressure. However, even within these data, it is clear that soil properties, contaminant form, and plant genera/species may dominate the system. For native plant species grown on U.S. western arid soils, CRs can range from 0.01 to 35 . Greenhouse studies with amended ${ }^{134} \mathrm{Cs}$, using calcareous and acidic soils, have shown extremely high CR values for olive and orange trees, both requiring high nutritional levels of potassium. On calcareous soils, CRs for leaves, edible fruit, and skin/peel of orange trees were 1.8, 2.8, and 2.7, respectively. For acidic soils, values were 47, 90, and 65, respectively. For calcareous soils, CRs for leaves and fruit of olive trees were 1.8 and 2.8, respectively. For acidic soils, values were 20.6 and 20, respectively. A study by Fuhrmann et al. (2002), using 40+ year-old contaminated soils from a Brookhaven National Laboratory (BNL) waste site yielded CRs of $0.17,0.46$, and 2.58 for Tepary bean, Indian mustard, and Redroot pigweed, respectively.

A survey of field studies shows a similar pattern. For the Marshal Islands plant foliage, reported CR values for foliage had a range of 1.1 to 39 , while associated fruits ranged from 0.23 to 8.7. A compilation of CRs for various edible food crops reported by Nisbet and Woodman (2000) show CRs ranging from 5.2E-3 for onion to 0.17 for green vegetables. Carini (2001) compiled various sources for cesium transfer to fruits. If we look at CRs from fallout, and only field studies, CRs for a wide variety of edible fruits range from E-1 to E-6, with expected high potassium plants having higher $\mathrm{CR}$ values. 
Table 3.1. Compiled Soil/Plant and Foliar Deposition References

\begin{tabular}{|c|c|c|c|c|c|}
\hline Isotope/Metal & Plant Species & Qualifying Conditions & Environment & $\begin{array}{c}\text { Transfer } \\
\text { Factor }\end{array}$ & Reference \\
\hline \multicolumn{6}{|l|}{ Cesium } \\
\hline \multirow[t]{2}{*}{${ }^{137} \mathrm{Cs}$} & Tumbleweed & Burbank sandy loam & Growth chamber & $0.025-0.053$ & Routson and Cataldo 1978a \\
\hline & Bean & Unnamed (sand) & LANL & 0.15 & White et al. 1981 \\
\hline${ }^{137} \mathrm{Cs}$ & Squash & Unnamed (sand) & LANL & 0.25 & White et al. 1981 \\
\hline${ }^{137} \mathrm{Cs}$ & Barley & Ephrata silt loam & Growth chamber & $3.0-6.0 \times 10-3$ & Cline 1981 \\
\hline${ }^{137} \mathrm{Cs}$ & Trees & Unnamed (WA) & Hanford & $0.02-0.06$ & Landeen and Mitchell 1986 \\
\hline${ }^{137} \mathrm{Cs}$ & Crested wheatgrass & Various & INEL & $0.619-0.81$ & Arthur 1982 \\
\hline${ }^{137} \mathrm{Cs}$ & Trees & Various & Northern Europe & $0.027-0.28$ & Livens et al. 1991 \\
\hline${ }^{137} \mathrm{Cs}$ & Bilberry & Various & Northern Europe & $0.25-1.62$ & Livens et al. 1991 \\
\hline${ }^{137} \mathrm{Cs}$ & Tumbleweed & Various & INEL & $5.4-35.1$ & Arthur 1982 \\
\hline${ }^{134} \mathrm{Cs}$ & Cheatgrass & Rupert (Hanford) & Growth chamber & 0.064 & Cataldo et al. $1978 \mathrm{~b}$ \\
\hline${ }^{134} \mathrm{Cs}$ & Cheatgrass & Ritzville (Hanford) & Growth chamber & 0.031 & Cataldo et al. $1978 \mathrm{~b}$ \\
\hline${ }^{134} \mathrm{Cs}$ & Cheatgrass & Lickskillet (Hanford) & Growth chamber & 0.015 & Cataldo et al. 1978b \\
\hline${ }^{134} \mathrm{Cs}$ & Tumbleweed & Rupert (Hanford) & Growth chamber & 0.014 & Cataldo et al. 1978b \\
\hline${ }^{134} \mathrm{Cs}$ & Tumbleweed & Ritzville (Hanford) & Growth chamber & 0.066 & Cataldo et al. 1978b \\
\hline${ }^{134} \mathrm{Cs}$ & Tumbleweed & Lickskillet (Hanford) & Growth chamber & 0.0078 & Cataldo et al. 1978b \\
\hline${ }^{132} \mathrm{Cs}^{*}$ & Atriplex canescens & Sandy (Mojave) & Greenhouse & $0.116-0.48$ & Wallace et al. 1971 \\
\hline \multirow[t]{3}{*}{${ }^{137} \mathrm{Cs}$} & \multirow[t]{3}{*}{ Panicum virginatum } & \multirow[t]{3}{*}{ Sand/peat } & Greenhouse/INEL & & \multirow[t]{3}{*}{ Entry and Watrud 1998} \\
\hline & & & Foliage & 3.21 & \\
\hline & & & Root & 0.49 & \\
\hline \multirow[t]{4}{*}{${ }^{137} \mathrm{Cs}$} & \multirow[t]{4}{*}{ Meadow grass } & \multirow[t]{4}{*}{4 CIS sites/Cher fallout } & Field/Sawichi, Belarussia (2 yr) & $5.6,6.2$ & \multirow[t]{4}{*}{ Vidal et al. 2001} \\
\hline & & & Field/Dublin, Belarussia (2yr) & 58,49 & \\
\hline & & & Field/Christinovka, UK (2 yr) & 0.2 & \\
\hline & & & Field/VIUA, Russia & $23.6,23.7$ & \\
\hline \multirow[t]{3}{*}{${ }^{137} \mathrm{Cs}$} & Redroot pigweed & $40+$ year old soil & \multirow[t]{3}{*}{ Greenhouse } & 2.58 & \multirow[t]{3}{*}{ Fuhrmann et al. 2002} \\
\hline & Indian mustard & BNL waste facility & & 0.46 & \\
\hline & Tepary bean & & & 0.17 & \\
\hline \multirow[t]{4}{*}{${ }^{137} \mathrm{Cs}$} & \multirow[t]{4}{*}{ Silax viminalis } & \multirow[t]{4}{*}{ Loam/clay loam } & Sweden/field/fallout & & \multirow[t]{4}{*}{ Fircks et al. 2002} \\
\hline & & & Leaves & $5 \mathrm{E}-5$ to $2 \mathrm{E}-4$ & \\
\hline & & & Stems & $2 \mathrm{E}-5$ to $1 \mathrm{E}-4$ & \\
\hline & & & Roots & $1 \mathrm{E}-4$ to $1.3 \mathrm{E}-3$ & \\
\hline \multirow[t]{2}{*}{${ }^{137} \mathrm{Cs}$} & \multirow[t]{2}{*}{ Brassica oleracea } & Field/Chern $/ 3$ km & Chistogalova/particles and condensation products & $0.01 \pm 0.01$ & \multirow[t]{2}{*}{ Malek et al. 2002} \\
\hline & & Field/Chern $/ 60 \mathrm{~km}$ & Polesskoye/condensation & $1.3 \pm 0.4$ & \\
\hline
\end{tabular}


Table 3.1. (contd)

\begin{tabular}{|c|c|c|c|c|c|}
\hline Isotope/Metal & Plant Species & Qualifying Conditions & Environment & Transfer Factor & Reference \\
\hline \multicolumn{6}{|l|}{ Cesium (contd) } \\
\hline \multirow[t]{8}{*}{${ }^{137} \mathrm{Cs}$} & \multirow[t]{8}{*}{ Various edible crops } & \multirow[t]{8}{*}{ Defined soils, various sources } & Field/Lysimeter/Compiled & & \multirow[t]{8}{*}{ Nisbet and Woodman 2000} \\
\hline & & & Cereals & $1.9 \mathrm{E}-2$ & \\
\hline & & & Tubers & $5.6 \mathrm{E}-2$ & \\
\hline & & & Green vegetables & 0.17 & \\
\hline & & & Brassicas & 0.1 & \\
\hline & & & Root vegetables & $4.8 \mathrm{E}-2$ & \\
\hline & & & Legumes & $3.1 \mathrm{E}-2$ & \\
\hline & & & Onions & $5.2 \mathrm{E}-3$ & \\
\hline \multirow[t]{11}{*}{${ }^{134} \mathrm{Cs}$} & \multirow[t]{11}{*}{ Olive/orange trees } & \multirow[t]{11}{*}{ Defined calc and acidic soil } & GH/3 year/Amend (calc/acidic) & & \multirow[t]{11}{*}{ Skarlou et al. 1999} \\
\hline & & & Calc/orange tree/new leaves & 1.8 & \\
\hline & & & Edible fruit & 2.8 & \\
\hline & & & Skin/peel & 2.7 & \\
\hline & & & Acid/orange tree/new leaves & 47 & \\
\hline & & & Edible fruit & 90 & \\
\hline & & & Skin/peel & 65 & \\
\hline & & & Calc/olive tree/new leaves & 1.8 & \\
\hline & & & Fruit & 2.8 & \\
\hline & & & Acid/olive tree/new leaves & 20.6 & \\
\hline & & & Fruit & 20 & \\
\hline \multirow[t]{3}{*}{${ }^{137} \mathrm{Cs}$} & \multirow[t]{3}{*}{ Tropical plants/fruit } & \multirow[t]{3}{*}{ Marshal islands } & Field & & \multirow[t]{3}{*}{ Simon et al. 2002} \\
\hline & & & Fruits & $0.23-8.7$ & \\
\hline & & & Various plants & $1.1-39$ & \\
\hline Cs, mixed & Numerous plants/fruits & Various soils & Various fruits & $4 \mathrm{e}-4$ to 3.8 & Carini 2001 \\
\hline \multirow[t]{4}{*}{${ }^{137} \mathrm{Cs}$} & \multirow[t]{4}{*}{ Salix viminalis } & \multirow[t]{4}{*}{ Sweden, defined } & Field/Chern & & \multirow[t]{4}{*}{ Fircks et al. 2002} \\
\hline & & & Leaves & $2 \mathrm{E}-5$ to $1 \mathrm{E}-4$ & \\
\hline & & & Stems & $5 \mathrm{E}-5$ to $2 \mathrm{E}-4$ & \\
\hline & & & Roots & $1 \mathrm{E}-4$ to $1.3 \mathrm{E}-3$ & \\
\hline \multicolumn{6}{|l|}{ Strontium } \\
\hline${ }^{90} \mathrm{Sr}$ & Tumbleweed & Burbank sandy loam & Growth chamber & $9.6-19.0$ & Routson and Cataldo 1978a \\
\hline${ }^{90} \mathrm{Sr}$ & Barley & Ephrata silt loam & Growth chamber & $1.63-2.15$ & Cline 1981 \\
\hline${ }^{90} \mathrm{Sr}$ & Trees & Unnamed (WA) & Hanford & $63.8-85.3$ & Landeen and Mitchell 1986 \\
\hline${ }^{90} \mathrm{Sr}$ & Crested wheatgrass & Various & INEL & 0.85 & Arthur 1982 \\
\hline${ }^{90} \mathrm{Sr}$ & Tumbleweed & Various & INEL & 4.5 & Arthur 1982 \\
\hline${ }^{85} \mathrm{Sr}$ & Barley & Ephrata silt loam & Growth chamber & $0.62-2.60$ & Cline 1981 \\
\hline${ }^{85} \mathrm{Sr}$ & Cheatgrass & Rupert (Hanford) & Growth chamber & 12 & Cataldo and Wildung 1978a \\
\hline
\end{tabular}


Table 3.1. (contd)

\begin{tabular}{|c|c|c|c|c|c|}
\hline Isotope/Metal & Plant Species & "Qualifying Conditions & "Environment & Transfer Factor & Reference \\
\hline \multicolumn{6}{|c|}{ Strontium (contd) } \\
\hline${ }^{85} \mathrm{Sr}$ & Cheatgrass & Burbank sandy loam & Growth chamber & 12 & Cataldo and Wildung 1978a \\
\hline${ }^{85} \mathrm{Sr}$ & Cheatgrass & Lickskillet (Hanford) & Growth chamber & 3.5 & Cataldo and Wildung 1978a \\
\hline${ }^{85} \mathrm{Sr}$ & Tumbleweed & Rupert (Hanford) & Growth chamber & 16 & Cataldo and Wildung 1978a \\
\hline${ }^{85} \mathrm{Sr}$ & Tumbleweed & Burbank sandy loam & Growth chamber & 8.7 & Cataldo and Wildung 1978a \\
\hline${ }^{85} \mathrm{Sr}$ & Tumbleweed & Lickskillet (Hanford) & Growth chamber & 4.4 & Cataldo and Wildung 1978a \\
\hline \multirow[t]{3}{*}{${ }^{90} \mathrm{Sr}$} & \multirow[t]{3}{*}{ Panicum virginatum } & \multirow[t]{3}{*}{ Sand/peat } & Greenhouse/INEL & & \multirow[t]{3}{*}{ Entry and Watrud 1998} \\
\hline & & & Foliage & 22.2 & \\
\hline & & & Root & 9.8 & \\
\hline \multirow[t]{3}{*}{${ }^{90} \mathrm{Sr}$} & \multirow[t]{3}{*}{ Meadow grass } & \multirow[t]{3}{*}{3 CIS sites/fallout } & Field/Sawichi, Belarussia (2 yr) & 25,21 & \multirow[t]{3}{*}{ Vidal et al. 2001} \\
\hline & & & Field/Dublin, Belarussia (2 yr) & 9,8 & \\
\hline & & & Field/Christinovka UK (2 yr) & 5,5 & \\
\hline \multirow[t]{3}{*}{${ }^{90} \mathrm{Sr}$} & Redroot pigweed & $40+$ year old soil & \multirow[t]{3}{*}{ Greenhouse } & 6.5 & \multirow[t]{3}{*}{ Fuhrmann et al. 2002} \\
\hline & Indian mustard & BNL waste facility & & 8.2 & \\
\hline & Tepary bean & & & 15.2 & \\
\hline \multirow[t]{4}{*}{${ }^{90} \mathrm{Sr}$} & \multirow[t]{4}{*}{ Silax viminalis } & \multirow[t]{4}{*}{ Loam/clay loam } & Sweden/field/fallout & & \multirow[t]{4}{*}{ Fircks et al. 2002} \\
\hline & & & Leaves & $3.9 \mathrm{E}-3$ to $7.6 \mathrm{E}-3$ & \\
\hline & & & Stems & $2.1 \mathrm{E}-3$ to $3.6 \mathrm{E}-3$ & \\
\hline & & & Roots & $2.8 \mathrm{E}-3$ & \\
\hline \multirow[t]{2}{*}{${ }^{90} \mathrm{Sr}$} & \multirow{2}{*}{ Brassica oleracea } & Field/Chern $/ 3 \mathrm{~km}$ & Chistogalova/particles and condensation products & $7 \pm 4$ & \multirow{2}{*}{ Malek et al. 2002} \\
\hline & & Field/Chern/60 km & Polesskoye/condensation & $18 \pm 9$ & \\
\hline \multirow[t]{8}{*}{${ }^{90} \mathrm{Sr}$} & \multirow[t]{8}{*}{ Various edible crops } & \multirow[t]{8}{*}{ Defined soils, various sources } & Field/Lysimeter/compiled & & \multirow[t]{8}{*}{ Nisbet and Woodman 2000} \\
\hline & & & Cereals & $1.2 \mathrm{E}-1$ & \\
\hline & & & Tubers & $1.4 \mathrm{E}-1$ & \\
\hline & & & Green vegetables & 1.9 & \\
\hline & & & Brassicas & 1.8 & \\
\hline & & & Root vegetables & 1.2 & \\
\hline & & & Legumes & 1.3 & \\
\hline & & & Onions & 0.68 & \\
\hline Sr, mixed & Numerous plants/fruits & Various soils & Various Fruits & $1.32 \mathrm{E}-3$ to 0.2 & Carini 2001 \\
\hline \multirow[t]{4}{*}{${ }^{90} \mathrm{Sr}$} & \multirow[t]{4}{*}{ Salix viminalis } & \multirow[t]{4}{*}{ Sweden, defined } & Field/Chern & & \multirow[t]{4}{*}{ Fircks et al. 2002} \\
\hline & & & Leaves & $3.9 \mathrm{E}-3$ to $7.6 \mathrm{E}-3$ & \\
\hline & & & Stems & $2.1 \mathrm{E}-3$ to $3.6 \mathrm{E}-3$ & \\
\hline & & & Roots & $2.8 \mathrm{E}-3$ & \\
\hline
\end{tabular}


Table 3.1. (contd)

\begin{tabular}{|c|c|c|c|c|c|}
\hline Isotope/Metal & Plant Species & Qualifying Conditions & Environment & $\begin{array}{c}\text { Transfer } \\
\text { Factor }\end{array}$ & Reference \\
\hline \multicolumn{6}{|l|}{ Plutonium } \\
\hline${ }^{239} \mathrm{Pu}$ & Barley & Ephrata silt loam & Growth chamber & $1.3 \times 10-4$ & Wilson and Cline 1966 \\
\hline${ }^{238} \mathrm{Pu}$ & Bean & Unnamed (sandy) & LANL & $7.2 \times 10-2$ & White et al. 1981 \\
\hline${ }^{238} \mathrm{Pu}$ & Squash & Unnamed (sandy) & LANL & 0.12 & White et al.1981 \\
\hline${ }^{238} \mathrm{Pu}$ & Crested wheatgrass & Various & INEL & $0.013-0.042$ & Arthur 1982 \\
\hline${ }^{238} \mathrm{Pu}$ & Tumbleweed & Various & INEL & $0.083-0.66$ & Arthur 1982 \\
\hline${ }^{239} \mathrm{Pu}$ & Bean & Unnamed (sandy) & LANL & $5.8 \times 10-2$ & White et al.1981 \\
\hline${ }^{239} \mathrm{Pu}$ & Squash & Unnamed (sandy) & LANL & $9.7 \times 10-2$ & White et al.1981 \\
\hline${ }^{239} \mathrm{Pu}$ & Vegetation & Unnamed & Field (NV) & 0.1 & Garten et al. 1987 \\
\hline${ }^{239} \mathrm{Pu}$ & Landino Clover & Unnamed & Greenhouse & $1.4 \times 10-4$ & Romney et al. 1970 \\
\hline${ }^{239} \mathrm{Pu}$ & Crested wheatgrass & Various & INEL & $0.022-0.125$ & Arthur 1982 \\
\hline${ }^{239} \mathrm{Pu}$ & Tumbleweed & Various & INEL & $0.33-1.6$ & Arthur 1982 \\
\hline${ }^{239} \mathrm{Pu}$ & Trees & Unnamed & Hanford & $0.002-0.005$ & $\begin{array}{l}\text { Landeen and Mitchell } \\
1986\end{array}$ \\
\hline${ }^{239} \mathrm{Pu}$ & Alfalfa & Unnamed & Growth chamber & $1.1-8.26 \times 10-4$ & Romney et al. 1985 \\
\hline${ }^{239} \mathrm{Pu}$ & Wheat & Unnamed & Growth chamber & $1.1-8.26 \times 10-4$ & Romney et al. 1985 \\
\hline${ }^{239} \mathrm{Pu}$ & Bushbean (leaves) & Unnamed & Growth chamber & $9.9-72.4 \times 10-4$ & Romney et al. 1985 \\
\hline${ }^{239} \mathrm{Pu}$ & Carrot (leaves) & Unnamed & Growth chamber & $0.81-4.75 \times 10-3$ & Romney et al. 1985 \\
\hline${ }^{239} \mathrm{Pu}$ & Cheatgrass & Burbank sandy loam & Growth chamber & $0.017 \times 10-3$ & Price 1972 \\
\hline${ }^{239} \mathrm{Pu}$ & Tumbleweed & Burbank sandy loam & Growth chamber & $0.046 \times 10-3$ & Price 1972 \\
\hline${ }^{239} \mathrm{Pu}$ & Barley & NTS, unnamed & Growth chamber & $20 \times 10-6$ & Schultz et al. 1976 \\
\hline${ }^{239 / 240} \mathrm{Pu}$ & Mixed vegetables & Esk estuary, Sellafield UK & Reprocessing site, Field/GH & $1.5 \mathrm{E}-4$ & Livens et al. 1994 \\
\hline $\mathrm{Pu}$, mixed & Numerous plants/fruits & Various soils & Various fruits & $7.2 \mathrm{E}-7$ to $2.1 \mathrm{E}-2$ & Carini 2001 \\
\hline \multicolumn{6}{|l|}{ Uranium } \\
\hline${ }^{238} \mathrm{U}$ & Mixed species & U Tailings & Semi Arid & 0.8 & $\begin{array}{l}\text { Ibrahim and Whicker } \\
1988\end{array}$ \\
\hline \multirow[t]{7}{*}{$\mathrm{U}$} & Radish & Neutral sand & Growth chamber & 0.047 & \multirow{4}{*}{$\begin{array}{l}\text { Sheppard and Evenden } \\
1992\end{array}$} \\
\hline & Radish & Acid sand & Growth chamber & 0.237 & \\
\hline & Radish & Limed sand & Growth chamber & 0.094 & \\
\hline & Bean & Limed sand & Field Lysimeter & 0.066 & \\
\hline & Trees & Corse & Field & 0.024 & \multirow{2}{*}{$\begin{array}{l}\text { Sheppard and Evenden } \\
1988\end{array}$} \\
\hline & Shrubs & Corse & Field & 0.009 & \\
\hline & Vegetation & Unnamed & LANL & $0.02-.034$ & Hanson and Miera 1976 \\
\hline \multirow[t]{3}{*}{${ }^{238} \mathrm{U}$ (natural) } & \multirow[t]{3}{*}{ Arostis cap } & \multirow[t]{3}{*}{ Cambisol, Sweden } & Greenhouse & & \multirow[t]{3}{*}{ Tyler and Olsson 2001} \\
\hline & & & Shoot & $3 \mathrm{E}-4-2 \mathrm{E}-3$ & \\
\hline & & & Root & $0.08-0.36$ & \\
\hline
\end{tabular}


Table 3.1. (contd)

\begin{tabular}{|c|c|c|c|c|c|c|}
\hline Isotope/Metal & Plant Species & Qualifying Conditions & \multicolumn{2}{|c|}{ Environment } & Transfer Factor & Reference \\
\hline \multicolumn{7}{|l|}{ Uranium (contd) } \\
\hline \multirow[t]{3}{*}{${ }^{238} \mathrm{U}$ (natural) } & \multirow[t]{3}{*}{ Blueberry } & \multirow[t]{3}{*}{ Redstone soil, NH } & \multicolumn{2}{|l|}{ Field plots } & & \multirow[t]{3}{*}{ Morton et al. 2001} \\
\hline & & & \multicolumn{2}{|l|}{ Leaves } & 0.001 & \\
\hline & & & \multicolumn{2}{|l|}{ Stems } & 0.001 & \\
\hline${ }^{238 / 234} \mathrm{U}$ & Mixed herb-grass pasture & Granitic/alluvial soils & \multicolumn{2}{|c|}{ Field/Spain/mine impact } & 0.097 & Tome et al. 2001 \\
\hline${ }^{238,234} \mathrm{U}$ (natural) & Spartina densiflora & Marsh/Spain & \multicolumn{2}{|c|}{ Accumulations from fertilizer manufacture } & $0.046 \pm 0.02$ & $\begin{array}{l}\text { Martinez-Aguirre et al. } \\
1997\end{array}$ \\
\hline Natural U & Various & India/uranium area & \multicolumn{2}{|l|}{ Field collection } & $0.07-4.1$ & Singh et al. 2001 \\
\hline U, mixed & Melon & Various soils & \multicolumn{2}{|l|}{ Melon } & $1.1-3.7 \mathrm{E}-3$ & Carini 2001 \\
\hline \multicolumn{7}{|l|}{ Thorium } \\
\hline \multirow[t]{3}{*}{${ }^{232} \mathrm{Th}$} & \multirow[t]{3}{*}{ Arostis capillaris } & \multirow[t]{3}{*}{ Cambisol, Sweden } & \multicolumn{2}{|l|}{ Greenhouse } & & \multirow[t]{3}{*}{ Tyler and Olsson 2001} \\
\hline & & & \multirow{2}{*}{\multicolumn{2}{|c|}{$\begin{array}{l}\text { Shoot } \\
\text { Root }\end{array}$}} & $2 \mathrm{E}-4-3 \mathrm{E}-3$ & \\
\hline & & & & & $0.01-0.12$ & \\
\hline \multirow[t]{3}{*}{${ }^{232} \mathrm{Th}$} & \multirow[t]{3}{*}{ Blueberry } & \multirow[t]{3}{*}{ Redstone soil, NH } & \multicolumn{2}{|l|}{ Field plots } & & \multirow[t]{3}{*}{ Morton et al. 2001} \\
\hline & & & \multirow{2}{*}{\multicolumn{2}{|c|}{$\begin{array}{l}\text { Leaves } \\
\text { Stems }\end{array}$}} & 0.005 & \\
\hline & & & & & 0.0025 & \\
\hline${ }^{230} \mathrm{Th}$ & $\begin{array}{l}\text { Mixed herb-grass pasture } \\
\text { granitic/alluvial soils }\end{array}$ & Field/Spain/mine impact & \multicolumn{2}{|l|}{ Stems } & 0.076 & Tome et al. 2001 \\
\hline $\begin{array}{l}{ }^{232,228} \mathrm{Th} \\
\text { (natural) }\end{array}$ & Spartina densiflora & Marsh/Spain & Accumulations fro & & $0.023 \pm 0.011$ & Martinez-Aguirre 1997 \\
\hline Th & Melon & Various soil & Melon & & $4.9 \mathrm{E}-4$ & Carini 2001 \\
\hline Neptunium & & & & & & \\
\hline${ }^{235 / 237} \mathrm{~Np}$ & Various plants & Ritzville silt loam & Growth chamber & & & Cataldo et al. 1988 \\
\hline & & & Bushbean & Leaves & 2.7 & \\
\hline & & & & Seed & 0.2 & \\
\hline & & & Barley & $\begin{array}{l}\text { Sheath/B } \\
\text { lade }\end{array}$ & 0.5 & \\
\hline & & & & Grain & 0.05 & \\
\hline & & & Soybean & Leaves & 1.5 & \\
\hline & & & Alfalfa & Leaves & 4.2 & \\
\hline Americium & & & & & & \\
\hline $\mathrm{Am}$ & Tumbleweed & Burbank, L. Sa. & Growth chamber & & $3.5 \times 10-2$ & Price 1972 \\
\hline $\mathrm{Am}$ & Cheatgrass & Burbank, L. Sa. & Growth chamber & & $1.5 \times 10-2$ & Price 1972 \\
\hline${ }^{241} \mathrm{Am}$ & Crested wheatgrass & Various & INEL & & $0.027-0.567$ & Arthur 1982 \\
\hline${ }^{241} \mathrm{Am}$ & Alfalfa & NTS unnamed & Growth chamber & & $0.04-1.17 \times 10-2$ & Romney et al. 1985 \\
\hline${ }^{241} \mathrm{Am}$ & Wheat & NTS unnamed & Growth chamber & & $0.008-2.08 \times 10-2$ & Romney et al. 1985 \\
\hline${ }^{241} \mathrm{Am}$ & Bushbean (leaves) & NTS unnamed & Growth chamber & & $0.90-17.7 \times 10-2$ & Romney et al. 1985 \\
\hline${ }^{241} \mathrm{Am}$ & Carrot (leaves) & NTS unnamed & Growth chamber & & $0.44-3.00 \times 10-2$ & Romney et al. 1985 \\
\hline
\end{tabular}


Table 3.1. (contd)

\begin{tabular}{|c|c|c|c|c|c|}
\hline Isotope/Metal & Plant Species & Qualifying Conditions & Environment & Transfer Factor & Reference \\
\hline \multicolumn{6}{|c|}{ Americium (contd) } \\
\hline${ }^{241} \mathrm{Am}$ & Tumbleweed & Burbank (Hanford) & Growth chamber & $1.40 \times 10-3$ & Price 1972 \\
\hline${ }^{241} \mathrm{Am}$ & Cheatgrass & Burbank (Hanford) & Growth chamber & $0.60 \times 10-3$ & Price 1972 \\
\hline${ }^{241} \mathrm{Am}$ & Barley & NTS, unnamed & Growth chamber & $92 \times 10-6$ & Schultz et al. 1976 \\
\hline${ }^{241} \mathrm{Am}$ & Mixed vegetables & Esk estuary, Sellafield UK & Reprocessing site, Field/GH & $1.7 \mathrm{E}-4$ & Livens et al. 1994 \\
\hline Am, mixed & Numerous plants/fruits & Various soils & Various fruits & 7.2E-4 to $6.8 \mathrm{E}-7$ & Carini 2001 \\
\hline \multicolumn{6}{|l|}{ Curium } \\
\hline $\mathrm{Cm}$, mixed & Numerous plants/fruits & Various soils & Various fruits & 3 to $6 \mathrm{E}-4$ & Carini 2001 \\
\hline \multicolumn{6}{|l|}{ Technetium } \\
\hline${ }^{99} \mathrm{Tc}$ & Tumbleweed & Burbank sandy loam & Growth chamber & $213-232$ & $\begin{array}{l}\text { Routson and Cataldo } \\
1977,1978 \text { a }\end{array}$ \\
\hline${ }^{99} \mathrm{Tc}$ & Tumbleweed & Rupert (Hanford) & Growth chamber & $315-357$ & $\begin{array}{l}\text { Routson and Cataldo } \\
1977,1978 \text { a }\end{array}$ \\
\hline${ }^{99} \mathrm{Tc}$ & Tumbleweed & Ritzville (Hanford) & Growth chamber & $314-390$ & $\begin{array}{l}\text { Routson and Cataldo } \\
1977,1978 \mathrm{a}\end{array}$ \\
\hline${ }^{99} \mathrm{Tc}$ & Tumbleweed & Lickskillet (Hanford) & Growth chamber & $76-127$ & $\begin{array}{l}\text { Routson and Cataldo } \\
1977,1978 \text { a }\end{array}$ \\
\hline${ }^{99} \mathrm{Tc}$ & Tumbleweed & Warden (Hanford) & Growth chamber & $155-183$ & $\begin{array}{l}\text { Routson and Cataldo } \\
1977,1978 \mathrm{a}\end{array}$ \\
\hline${ }^{99} \mathrm{Tc}$ & Cheatgrass & Burbank sandy loam & Growth chamber & $104-112$ & $\begin{array}{l}\text { Routson and Cataldo } \\
1977,1978 \text { a }\end{array}$ \\
\hline${ }^{99} \mathrm{Tc}$ & Cheatgrass & Ritzville (Hanford) & Growth chamber & $158-192$ & $\begin{array}{l}\text { Routson and Cataldo } \\
1977,1978 \text { a }\end{array}$ \\
\hline${ }^{99} \mathrm{Tc}$ & Cheatgrass & Lickskillet (Hanford) & Growth chamber & $54-114$ & $\begin{array}{l}\text { Routson and Cataldo } \\
1977,1978 \text { a }\end{array}$ \\
\hline${ }^{99} \mathrm{Tc}$ & Cheatgrass & Warden (Hanford) & Growth chamber & $130-220$ & $\begin{array}{l}\text { Routson and Cataldo } \\
1977,1978 \text { a }\end{array}$ \\
\hline${ }^{99} \mathrm{Tc}$ & Cheatgrass & Rupert (Hanford) & Growth chamber & $91-185$ & Cataldo 1979 \\
\hline${ }^{99} \mathrm{Tc}$ & Cheatgrass & Rupert subsoil (Hanford) & Growth chamber & $309-640$ & Cataldo 1979 \\
\hline${ }^{99} \mathrm{Tc}$ & Tumbleweed & Rupert (Hanford) & Growth chamber & $82-148$ & Cataldo 1979 \\
\hline${ }^{99} \mathrm{Tc}$ & Tumbleweed & Rupert subsoil (Hanford) & Growth chamber & $173-881$ & Cataldo 1979 \\
\hline${ }^{99} \mathrm{Tc}$ & Fescue & ORNL & Field & 37 & Garten et al. 1984 \\
\hline${ }^{99} \mathrm{Tc}$ & Barley, potato, tomato & Unknown & $\mathrm{GH}$ & $76-174$ & Dehut et al. 1989 \\
\hline \multicolumn{6}{|l|}{ Iodine } \\
\hline I, mixed & Numerous plants/fruits & Various soils & Various fruits & $3 \mathrm{E}-2$ to $4 \mathrm{E}-4$ & Carini 2001 \\
\hline $\mathrm{I}$ & Rye and wheat & Various & Cereal grains & $8.1 \mathrm{E}-3$ to $4.7 \mathrm{E}-4$ & Shinonaga et al. 2001 \\
\hline
\end{tabular}


Table 3.1. (contd)

\begin{tabular}{|c|c|c|c|c|c|}
\hline \multicolumn{6}{|c|}{ Selenium } \\
\hline \multirow[t]{3}{*}{${ }^{78} \mathrm{Se}$} & \multirow[t]{3}{*}{ Arostis capillaris } & \multirow[t]{3}{*}{ Cambisol, Sweden } & Greenhouse & & \multirow[t]{3}{*}{ Tyler and Olsson 2001} \\
\hline & & & Shoot & $0.05-0.08$ & \\
\hline & & & Root & $0.08-0.32$ & \\
\hline \multicolumn{6}{|l|}{ Silver } \\
\hline \multirow[t]{3}{*}{${ }^{107} \mathrm{Ag}$} & \multirow[t]{3}{*}{ Arostis capillaris } & \multirow[t]{3}{*}{ Cambisol, Sweden } & Greenhouse & & \multirow[t]{3}{*}{ Tyler and Olsson 2001} \\
\hline & & & Shoot & $0.01-0.06$ & \\
\hline & & & Root & $0.85-0.89$ & \\
\hline \multirow[t]{3}{*}{$\mathrm{Ag}$} & \multirow[t]{3}{*}{ Soybean } & \multirow[t]{3}{*}{ Ritzville silt-loam } & Growth chamber & & \multirow{3}{*}{$\begin{array}{l}\text { Cataldo and Wildung } \\
1978 b\end{array}$} \\
\hline & & & Endogenous & 0.057 & \\
\hline & & & Amended & 0.001 & \\
\hline \multicolumn{6}{|c|}{ Beryllium } \\
\hline \multirow[t]{3}{*}{${ }^{9} \mathrm{Be}$} & \multirow[t]{3}{*}{ Arostis capillaris } & \multirow[t]{3}{*}{ Cambisol, Sweden } & Greenhouse & & \multirow[t]{3}{*}{ Tyler and Olsson 2001} \\
\hline & & & Shoot & $3 \mathrm{E}-4-1.6 \mathrm{E}-3$ & \\
\hline & & & Root & $1.6 \mathrm{E}-2-0.09$ & \\
\hline \multicolumn{6}{|c|}{ Niobium } \\
\hline \multirow[t]{3}{*}{${ }^{92} \mathrm{Nb}$} & \multirow[t]{3}{*}{ Arostis capillaris } & \multirow[t]{3}{*}{ Cambisol, Sweden } & Greenhouse & & \multirow[t]{3}{*}{ Tyler and Olsson 2001} \\
\hline & & & Shoot & $0.005-0.04$ & \\
\hline & & & Root & $0.38-1.2$ & \\
\hline \multicolumn{6}{|l|}{ Nickel } \\
\hline \multirow[t]{2}{*}{${ }^{63} \mathrm{Ni}$} & Wheat & Various & Growth chamber & $0.12-0.75$ & \multirow[t]{2}{*}{ Denys et al. 2002} \\
\hline & Clover & Various & Growth chamber & $0.98-4.0$ & \\
\hline${ }^{58} \mathrm{Ni}$ & Arostis capillaris & Cambisol, Sweden & Greenhouse & & Tyler and Olsson 2001 \\
\hline & & & Shoot & $0.13-0.29$ & \\
\hline & & & Root & $0.46-1.39$ & \\
\hline $\mathrm{Ni}$ & Melon & Various soil & Melon & $4.2 \mathrm{E}-3$ & Carini 2001 \\
\hline${ }^{63 / 58} \mathrm{Ni}$ & Soybean & Ritzville silt loam & Growth chamber & & Cataldo et al. 1978a \\
\hline & & & Endogenous & 0.022 & \\
\hline & & & Amended & 5.72 & \\
\hline Tin & & & & & \\
\hline${ }^{63} \mathrm{Ni}$ & Soybean & Ritzville silt loam & Growth chamber & & Cataldo and Wildung \\
\hline & & & Endogenous & $>1.1$ & $1978 \mathrm{a}$ and $1978 \mathrm{~b}$ \\
\hline & & & Amended & 0.38 & \\
\hline Foliar & & & & & \\
\hline${ }^{137} \mathrm{Cs}$ & Brassica oleracea & Field/Chern/3km & Chistogalova/particles and condensation products & $5 \mathrm{E}-4 \pm 4.2 \mathrm{E}-4$ & Malek et al. 2002 \\
\hline & & Field/Chern $/ 60 \mathrm{~km}$ & Polesskoye/condensation & $18 \pm 9$ & \\
\hline${ }^{90} \mathrm{Sr}$ & Brassica oleracea & Field/Chern $/ 3 \mathrm{~km}$ & Chistogalova/particles and condensation products & $0.02 \pm 0.03$ & Malek et al. 2002 \\
\hline & & Field/Chern $/ 60 \mathrm{~km}$ & Polesskoye/condensation & $2.3 \pm 1.6$ & \\
\hline
\end{tabular}


Some of the most interesting data comes from analyzing fallout from Chernobyl. While much of the collected data need to be tabulated and correlated with process variables, some data are very informative. In a study by Vidal et al. (2001), Chernobyl fallout sites were investigated at four locations within the residual fallout patterns within the Confederation of Independent States (CIS) and the United Kingdon (UK). For meadow grasses, CRs for two sites located in Belarussia ranged from 6 to 50 with 23 for a site in Russia and 0.2 for a site in the UK. An interesting study by Malek et al. (2002) looked at the difference in CR for Brassica at $3 \mathrm{~km}$ (particles and condensation products) and $60 \mathrm{~km}$ (condensation products) from Chernobyl. CRs at $3 \mathrm{~km}$ were 0.01 , versus 1.3 at $60 \mathrm{~km}$, indicating that the contaminant physicochemical form was impacting plant availability and subsequent $C R$ values.

Projected Conclusions/Needs/Options. Mono-valent cesium represents a relatively simple ion from a geochemical process standpoint. However, as with other ions, extremes in variability exist with respect to CRs. In the case of cesium, two factors are believed to be dominating CR behavior. The first is cesium concentration, and the second is its analogue behavior to potassium. These two factors go a long way in explaining the low CR values at low contaminant concentrations, and also the very large variability seen with individual plant types, i.e., need and ability to accumulate potassium.

\subsubsection{Strontium}

Environmental Behavior. Strontium exists in the environment in the $\mathrm{Sr}(\mathrm{II})$ oxidation state. While the crustal abundance of strontium is approximately $150 \mathrm{mg} / \mathrm{kg}$, the total concentration range in soils is between 50 and $1000 \mathrm{mg} / \mathrm{kg}$ (Lindsay 1979). Strontium is usually present in the surface environment as a carbonate or a sulfate mineral and can isomorphically substitute for calcium in carbonates and sulfates. The most important of the 12 nonstable isotopes of strontium are ${ }^{85} \mathrm{Sr},{ }^{89} \mathrm{Sr}$, and ${ }^{90} \mathrm{Sr}$. As a result of nuclear-weapons testing, ${ }^{90} \mathrm{Sr}$ is distributed widely in the geosphere. The chemistry of strontium and calcium are closely related. The dominant aqueous strontium species in natural waters over a broad $\mathrm{pH}$ range ( 2 to 9 ) is the free divalent $\mathrm{Sr}^{+2}$ species. The solubility of $\mathrm{Sr}^{+2}$ is not greatly affected by the presence of most inorganic anions because $\mathrm{Sr}^{+2}$ forms only weak aqueous complexes with $\mathrm{CO}_{3}{ }^{-2}, \mathrm{SO}_{4}{ }^{-2}, \mathrm{Cl}^{-}$, and $\mathrm{NO}_{3}{ }^{-}$. However, large concentrations of $\mathrm{SO}_{4}^{-2}$ or elevated alkalinity could play an important role in strontium mobility. Since strontium and calcium form humic acid complexes of similar stability (Stevenson and Fitch 1986), strontium should not effectively compete with calcium for humic acid ligands because calcium is typically present at much greater concentrations. Therefore, natural organic ligand-strontium species are not thought to greatly affect the solubility of strontium, and thus bioavailability.

Strontium Concentration Ratios. The uptake of ${ }^{90} \mathrm{Sr}$ from sediment or soil to plants is affected by the presence of the chemical analogue, calcium, in the systems. The observed ratio (O-R) described by Comar et al. (1956) relates the amount of ${ }^{90} \mathrm{Sr}$ and calcium in a sample to the amount of the radionuclide and competing element in the precursor. This empirically determined relationship has proven to be consistent. Most of the reported O-Rs have been determined for food chains leading to human consumers. Strontium uptake by plants, in general, is therefore greatest from soils of low calcium content and in many cases increased organic matter content (Paasikallio et al. 1994). Plant crops assimilate from $0.2 \%$ to $3 \%$ of the strontium in the soil 
(Comar 1965; Menzel 1963). It should also be noted that the availability to plants of soil ${ }^{90} \mathrm{Sr}$ decreases only slightly with time (Cline 1981; Paaskallio et al. 1994).

A review/tabulation of CR values for strontium, as with cesium, are far ranging, based on the controlling factors described above, and as delineated by environment and plant type in Table 3.1. Once again, for growth chamber and greenhouse studies, CR values for strontium can be assumed to be high due to cultivation pressure. Yet it is clear that soil properties, contaminant form, and plant genera/species may dominate the system once again. For native plant species grown on U.S. western arid soils, CRs can range from 0.6 to 85 . In the study by Fuhrmann et al. (2002), using 40+ year-old contaminated soils from a BNL waste site yielded CRs of 6.5, 8.2 and 15.2 for Redroot pigweed, Indian mustard and Tepary bean, respectively.

A survey of field studies shows a similar pattern. The compilation of CRs for various edible food crops reported by Nisbet and Woodman (2000), show CRs ranging from 5.2E-1 for cereals to 1.9 for green vegetables. Carini (2001) compiled various sources for strontium transfer to fruits. Once again, if we look at CRs from fallout, and only field studies, CRs for pear and grape are on the order of E-2.

Chernobyl fallout data again is most informative. In a study by Vidal et al. (2001), Chernobyl fallout sites were investigated at three locations within the residual fallout patterns within the CIS and UK. For meadow grasses, CRs for two sites located in Belarussia ranged from 8 to 21 after two years, and 5 for a site in the UK. The study by Malek et al. (2002) looked at the difference in CR for Brassica at $3 \mathrm{~km}$ (particles and condensation products) and $60 \mathrm{~km}$ (condensation products) from Chernobyl. CRs at $3 \mathrm{~km}$ were 7 versus 18 at $60 \mathrm{~km}$, indicating that the contaminant physicochemical form, once again, was impacting plant availability and subsequent CR values. In the compilation of Carini (2001), CRs for numerous fruits are provided, specifically looking at fallout from Chernobyl, two years post-event. CRs for pear, blackcurrant, red currant, and strawberry ranged from 1.1E-1 to 1.2E-2.

Projected Conclusions/Needs/Options. Di-valent strontium represents a relatively simple ion from a geochemical process standpoint. However, as with other ions, extremes in variability exist with respect to $\mathrm{CR}$, as with cesium. In the case of strontium, two factors are believed to be dominating CR behavior. The first is strontium concentration, and the secondly is its analogue behavior to calcium. These two factors go a long way in explaining the low CR values at low contaminant concentrations, and also the very large variability seen with individual plant types, i.e., need and ability to accumulate calcium.

\subsubsection{Technetium}

Environmental Behavior. Technetium, a product of thermal neutron fission of ${ }^{235} \mathrm{U}$ possesses several unique chemical and biological characteristics. Chemically, it can exist in all valence states from +7 to -1 . However, the $+7,+4$ and 0 states are the most stable (Wildung et al. 1977). In aqueous and aerobic environments such as surface soils, the +7 pertechnetate ion $\left(\mathrm{TcO}_{4}{ }^{-}\right)$ readily forms and is expected to dominate. As such, it is highly mobile, with plant availability being directly related to soil organic matter, and inversely related to $\mathrm{pH}$. (Landa et al. 1977; Sheppard et al. 1983; Wildung et al. 1986). Yet, in extended laboratory studies (Cataldo 1979; 
Mousny and Myttenaere 1981), and field studies (Garten et al. 1984), both solubility and plant availability of technetium are reduced over time. This indicates that technetium can readily undergo reduction $(+4)$ and reoxidation $(+7)$ even in surface soils (Hoffman et al. 1982).

Technetium Concentration Ratios. Reported CRs for technetium are unusually high compared to all other isotopes, and many essential nutrient ions. CRs based on soil technetium concentrations (upper $15 \mathrm{~cm}$ soil) are reported to range from 3 to 370 in plants adjacent to a western U.S. reprocessing facility (Garland et al. 1983), and from 2 to 200 for plants growing near a midwestern gaseous diffusion facility (Hoffman et al. 1980). In the Garland et al. (1983) study, CRs for cottonwood, tumble mustard, asparagus, willow leaves, sagebrush leaves and Russian knapweed were calculated at 2, 5, 7, 9, 160 and 230, respectively. The source of the technetium was from stack releases of volatile technetium from earlier reprocessing, with soil concentrations at 3 and $0.01 \mathrm{pg} / \mathrm{g}$ soil. Laboratory and greenhouse studies (Landa et al. 1977; Wildung et al. 1977; Mousny and Myttenaere 1981; Table 3.1) have consistently reported CRs of 2 to 1000.

The behavior of technetium in biological systems is believed to be supported by a range of physiological transport data that indicates that the pertechnetate ion is accumulated and/or absorbed using transport mechanisms in place for molybdate, selenate, sulfate and phosphate (Cataldo et al. 1983). Additionally, it appears from biochemical studies that technetium, once absorbed, is converted to organic forms (metabolites), and the subsequent chemistry and distribution in the plant mimics sulfur metabolism (Cataldo et al. 1989).

Projected Conclusions/Needs/Options. The perceived radiological risk from technetium, a weak beta emitter, may not accurately reflect the true risk of this environmentally and biologically mobile, and metabolically incorporated element. Plant and animal studies indicate that on metabolism of technetium, incorporation into normal S-containing proteins is indicated (Cataldo et al. 1989; Krijger et al. 1999; Thomas et al. 1984). More importantly, the chemistry of technetium precludes the analogous (to S) formation of disulfide bridges, and likely leads to nonfunctional proteins and metabolites.

\subsubsection{Iodine}

Environmental Behavior. Iodine-127 is normally present in soils globally at an average concentration of $5 \mathrm{ppm}$. Typical land plants and food crops contain from 0.07 to $10 \mathrm{ppm}$ of stable ${ }^{127} \mathrm{I}$. While the ratio of ${ }^{129} \mathrm{I}$ to ${ }^{127} \mathrm{I}$ is $10^{-14}$, it can normally be assumed that the two isotopes mimic each other, unless there is a disruption in ${ }^{129} \mathrm{I}$ from nuclear activities. It has long been believed that the dominant speciation patterns in the aerobic soil environment were $\mathrm{I}^{-}$and $\mathrm{IO}_{3}{ }^{-}$, and $\mathrm{I}_{2}$, and methyl iodine from the marine system. Results indicate that the iodine cycle may be more complex.

Iodine Concentration Ratios. Two more recent studies have shown iodine transfer from soil-toseed grain of rye and wheat to be represented by a CR of $8 \mathrm{E}-3$ to $5 \mathrm{E}-4$. In the compilation presented by Carini (2001), CRs for a variety of edible fruits ranged from 3E-2 to 4E-4 (Table 3.1). However, it is some of the older literature that is troublesome. Cline and Klepper (1975) obtained CRs of 0.1 to 1.0 for natural Hanford soils containing only natural/stable iodine forms. Subsequent studies by Garland et al. (1983) at various sites adjacent to a fuels reprocessing site 
showed a marked difference in the transfer of ${ }^{127} \mathrm{I}$ and ${ }^{129} \mathrm{I}$ from soils-to-plants. In these studies CRs for ${ }^{127}$ I were calculated at $0.08,1.2,0,22,0.2,0.38$ and 0.23 for tumble mustard, sagebrush leaves, Russian knapweed, and willow leaves, asparaus, and cottonwood leaves, respectively. CR values for ${ }^{129}$ I were $0.64,1.0,4.1,0.5,3.7$ and 1.5 for tumble mustard, sagebrush leaves, Russian knapweed, and willow leaves, asparagus, and cottonwood leaves, respectively. This would indicate that ${ }^{127} \mathrm{I}$ and ${ }^{129} \mathrm{I}$ are not following a similar behavior, with a factor of 5-10 greater availability for ${ }^{129} \mathrm{I}$, except for sagebrush leaves. The differential elemental concentrations in litter of sagebrush and willow is just as interesting. Here the CR values for ${ }^{127} \mathrm{I} /{ }^{129} \mathrm{I}$ for willow and sagebrush were $3.5 / 32.4$ and 3.8/24, respectively.

While differing CRs and litter accumulation rates could be explained away by a continuing influx of ${ }^{129}$ I from reprocessing and aerial deposition, the field locations were within and outside of the wind rows for the plant, and also iodine release from processing had drastically declined years earlier. This would suggest a secondary source of I, other than particulate or ionic, possibly a volatile source. In a follow on study by Wildung et al. (1986), the potential volatile component of the iodine cycle was investigated. A series of nine soils were used; ${ }^{229} \mathrm{I}$ concentrations ranged from 0.17 to $23 \mathrm{pg} / \mathrm{g}$. These were planted with soybean, maintained in an enclosed growth chamber, and harvested after 21-days. Analysis of the plant tissues indicated that although there was a factor of 135 -fold difference in soil concentrations, each plant had a

${ }^{129}$ I content that was similar, ranging from 62 to $85 \mathrm{pg} / \mathrm{g}$ tissue, and that there must be a volatile I component. Analysis of volatile iodine components (both organic and inorganic) from the gas phases of ${ }^{125} \mathrm{I}$ amended soils and plants grown on contaminated soils, showed the presence of a significant organic iodine cycle. Total volatiles represented $0.028 \%$ for soils and $0.12 \%$ for plants; of this $75 \%$ of the volatile releases were organic in nature.

Projected Conclusions/Needs/Options. It appears that I, while an essential element for both plants and animals, has a range in bioavailability from inorganic sources within soils. However, of more interest may be the volatile organic cycle in terrestrial systems, which may account for a continuous source of airborne contamination.

\subsubsection{Uranium}

Environmental Behavior. Uranium can exist in the $+3,+4,+5$, and the +6 oxidation state; however, only the +4 and +6 oxidation states are typically observed in the environment. Naturally occurring uranium typically contains 99.283 -percent ${ }^{238} \mathrm{U}, 0.711$-percent ${ }^{235} \mathrm{U}$, and 0.0054 percent ${ }^{234} \mathrm{U}$ by weight. The half-lives of these uranium isotopes are 4.51E9 years, 7.1E8 years, and 2.47E5years, respectively. Geologically, uranium occurs most often as U(IV) minerals, such as pitchblende, uraninite, carnotite, and autunite and as U(VI) uranophane. It is also found in phosphate rock, lignite, and monazite sands at levels that can be commercially recovered. In the presence of lignite and other sedimentary carbonaceous substances, uranium enrichment is believed to be the result of $\mathrm{UO}_{2}{ }^{+2}$ transport, adsorption or complexation by humic materials, and reduction of dissolved U(VI) to U(IV), followed by the formation of uraninite.

The aqueous $\mathrm{U}(\mathrm{VI})$ uranyl cation $\left(\mathrm{UO}_{2}{ }^{+2}\right)$ is the most stable ion in oxidizing solutions; the U(III) species easily oxidizes to U(IV) under most environmental conditions, while the U(V) aqueous species $\left(\mathrm{UO}_{2}^{+}\right)$readily disproportionates to $\mathrm{U}(\mathrm{IV})$ and $\mathrm{UO}_{2}{ }^{+2}$. In aqueous systems, the U(IV) 
species will not be present to any great degree as a result of precipitation; probably uraninite $\left(\mathrm{UO}_{2}\right)$ or some higher $\mathrm{O} / \mathrm{U}$ solids ratio with an $\mathrm{O} / \mathrm{U}$ ratio between 2.3 and 2.7 (Maynard 1983 as reported by Bruno et al. 1991). The average uranium concentrations in natural waters under reducing conditions are between 3 and $30 \mathrm{ppb}$ (Bruno et al. 1991); this is consistent with equilibrium concentrations supported by $\mathrm{UO}_{2}$ (s) (Bruno et al. 1988). In the absence of any complexing agents, $\mathrm{U}(\mathrm{IV})$ is expected to hydrolyze to form mononuclear hydroxo complexes, such as $\mathrm{U}(\mathrm{OH})_{\mathrm{n} 4-\mathrm{n}}$ (Langmuir 1978). It has been suggested that complexation of (IV) actinides form stable complexes with natural organic humic and fulvic acids (log K of 12-16; Allard and Persson as reported by Birch and Bachofen 1990); hence U(IV) could form stable organic complexes, increasing the aqueous concentration of U(IV).

Uranium Concentration Ratios. Transport of uranium from soil to biota has been well documented (Dreesen et al. 1982; Moffett and Tellier 1977; Mahon 1982; Table 3.1). It has been assumed in these studies that the nature of the soil determined the amount of bioavailable uranium. For example, soil conditions that favored decreased sorption or formation of soluble complexes with uranium enhanced uptake. Swiss chard grown in sandy soils contained uranium at concentrations 80 times higher than chard grown in peat (Sheppard et al. 1983). However, in another study of the effect of 11 different soil types on bioavailability indices for uranium (Sheppard and Evenden 1992), no correlation between plant or invertebrate uptake and soil parameters was observed. The soils were treated with up to $10,000 \mathrm{mg} \mathrm{U} / \mathrm{kg}$ soil and varied with regard to texture, clay, organic content, $\mathrm{pH}$, background uranium content, and CEC. Uranium concentrations in plants and earthworms were not linearly related to uranium concentrations in the soil. Thus, a single value for use as a conservative concentration ratio for a soil type could not be determined, and the implication is that other reported concentration ratios for uranium in plants should not be applied to soil concentrations outside those for which the concentration ratio was determined.

Recently, CRs have been reported for shoots, leaves, fruits and seeds; much of these were derived from soils containing either natural uranium or uranium amended at low soil concentration (Table 3.1). In greenhouse studies with natural uranium, Tyler and Olsen (2001) reported the normal CRs for roots and shoots at 0.08-0.36 and 3E-4 to 2E-3, respectively. Field studies based on natural uranium-containing soils have yielded CRs ranging from 0.07 to 4.1 (Singh et al. 2001). CRs for melon have shown to range from 1.1 to 3.7E-3 (Carini 2001).

Projected Conclusions/Needs/Options. Uranium, as an actinide, appears to be much more bioavailable than others in the series such as plutonium and thorium, while neptunium, americium, and curium may be more available. This likely results from its more complex chemistry and physicochemical factors that regulate stable/mobile ion formation. Another consideration is the potential for uranium toxicity in not only plants, but also the food chain. Behavior/transport appears related to soil concentrations and contaminant form.

\subsubsection{Plutonium}

Environmental Behavior. Plutonium is a product of the nuclear fuel cycle, and exists primarily in the +IV state, under normal environmental conditions. Depending on the waste stream/release scenario, plutonium can enter the environment as a refractory oxide, with low solubility and slow 
conversion kinetics, or as more reactive/mobile forms, including nitrates, carbonates, and hydroxides. As with many other (particularly early) studies, plutonium behavior and transport characteristics vary with both contaminant levels and form.

Plutonium Concentration Ratios. CR values for plutonium, overall, remain in the range of E-3 to E-6 for most plants investigated (Table 3.1). This relatively low availability and low transport potential likely arises from the propensity of plutonium to undergo hydrolysis. With plutonium, a serious consideration is the relative role of contaminant form with respect to plant availability. In a large multi-year field lysimeter study by Cline and Schreckhise (1987), we have calculated the relative ratio for plant availability for plutonium-nitrate and plutonium-oxide in specific plants and tissues as a reference to the potential role of chemical form on plant availability. In these studies, the relative bioavailability/uptake of nitrate versus oxide forms were 7.5 and $>10$ for leaves/stems and seeds of barley, and 7.7 and $>10$ for pea leaves and seed, respectively. This indicates a very real role for contaminant chemical form in bioavailability. However, several studies/observations complicate the interpretation of risk based on 40 years of laboratory and field studies. Carini (2001) in his compilation of plutonium accumulation factors for fruits notes several citations where transfer to fruits such as apples, stewed fruits, and blackberries (Coughtrey et al. 1984) show CRs of E-1 to E-3. The problem is why the 100- to 1000-fold increase of surface contamination is not evident. A study by Garland et al. (1981) noted that the normal hydrolytic nature of $\mathrm{Pu}(\mathrm{IV})$ was not evident for plutonium transported from root to all other aerial tissues. Tissue accumulation profiles for above ground soybean tissues followed over 85 days showed continual accumulation except for stems, which remained relatively constant and at levels much below all other plant tissues. Analysis of the xylem exudates of the stems and accumulating tissues clearly indicated that $\mathrm{Pu}(\mathrm{IV})$ is complexed for transport in the xylem and to aerial tissues, and subsequently accumulated in specific biochemical fractions of individual tissues, and does not reflect patterns expected for non-specific binding.

Projected Conclusions/Needs/Options. While CRs for plutonium follow a relatively consistent pattern, with comparatively low CRs, plutonium appears to be mobile in some plant systems. More importantly, the potential for plutonium to be accumulated in specific plants, and the indications that plutonium can be metabolically stabilized, may present an added food chain risk factor.

\subsubsection{Neptunium}

Environmental Behavior. Neptunium of all the actinides has a rather unique environmental chemistry. While neptunium can exist in many oxidation states, $\mathrm{NpO}_{2}{ }^{+}$appears to dominate (Nishita et al. (1981). This chemical preference may account for the mobility and plant availability of neptunium.

Neptunium Concentration Ratios. There is not a lot of soil/plant data available for neptunium. Some of the most interesting data are not reported in terms of CR. In one of these, a large multiyear field lysimeter study by Schreckhise and Cline (1980), we have calculated the relative ratio of $\mathrm{Np} / \mathrm{Pu}$ in specific plants and tissues as a reference to plant availability. The relative availability of neptunium, compared to plutonium, is 1200 and 1500 for cheatgrass and alfalfa leaves; 7,500 and 43,000 for barley stem/leaves and seed; and 3,500 and 370,000 for pea leaf and 
seed, respectively. These multi-year studies showed CRs to remain elevated. In a growth chamber/soil study by Cataldo et al. (1988), CRs for neptunium were reported at 2.7 and 0.2 for bushbean leaves and seed, 0.5 and 0.05 for barley leaves/sheath and grain; and 1.5 and 4.2 for soybean and alfalfa leaves, respectively. Further soil studies showed that CRs for bushbean leaves increased with soil concentration of neptunium; these increased (asymptotically) from 2 to 12 over a soil concentration range of $1 \mathrm{E}-6$ to $1 \mathrm{E} 0 \mathrm{mg} / \mathrm{g}$ soil. Chemical analyses of xylem exudates (transport forms) indicated a chemical complexation of the $\mathrm{NpO}_{2}{ }^{+}$ion with citric acid. This explains the plant mobility and lack of hydrolysis products.

Projected Conclusions/Needs/Options. Neptunium of all the actinides appears to be the most environmentally mobile and plant available. This may result from its dominant oxidation state (V), and the formation of $\mathrm{NpO}_{2}{ }^{+}$. In addition, its high plant availability and likely stabilization as organic complexation in tissues may have an unexpected impact on food-chain transfer.

\subsubsection{Americium}

Environmental Behavior. The environmental form of americium is likely the III and/or IV valence forms. This would be relatively consistent with the biological behavior of the actinides: $\mathrm{Np}>\mathrm{Cm}>\mathrm{Am}>\mathrm{Pu} / \mathrm{Th}$.

Americium Concentration Ratios. CRs for americium have generally been confined to laboratory studies (Table 3.1). The reported range in CRs is 0.5 to E-6. It is difficult to assess the reasons for the seemingly broad range, but it likely results from differences in contaminant source chemistry, amendment levels, and amendment methods. This said, there are some somewhat reasonable field evaluations. Livens et al. (1994) reported CRs of 1.7E-4 for mixed vegetation from an estuary impacted from a reprocessing site in the UK. Carini (2001) compiled several reports for americium from various sources for fruits; these CRs ranged from 7.2E-4 to 6.8E-7. These included data for field studies employing apple, berries, and tropical fruits. On the whole, it would appear that americium transfer to plants is a factor of 10 - to 100 -fold greater than for plutonium.

Projected Conclusions/Needs/Options. Unlike plutonium, americium studies have not been intensive nor extensive enough to fully delineate the roles of contaminant form and biological/soil factors on speciation and bioavailability.

\subsubsection{Curium}

Environmental Behavior. The environmental form of curium, as with americium, is likely the III and/or IV valence forms. This would be relatively consistent with the biological behavior of the actinides: $\mathrm{Np}>\mathrm{Cm}>\mathrm{Am}>\mathrm{Pu} / \mathrm{Th}$.

Curium Concentration Ratios. There is not a lot of soil/plant data available for curium. Some of the most interesting are not reported in terms of CR. In one of these, a large multi-year field lysimeter study by Schreckhise and Cline (1980), we have calculated the relative ratio of $\mathrm{Cm} / \mathrm{Pu}$ in specific plants and tissues as a reference to plant availability. The relative availability of curium, compared to plutonium, is 5.4 and 8.4 for cheatgrass and alfalfa leaves; 8.1 and 9.6 for 
barley stem/leaves and seed; and 12.6 and $>10$ for pea leaf and seed, respectively. These multiyear studies showed transfer factors to remain elevated. Carini (2001) lists reported data for transfer to fruit at 3E-4 to 6E-4 for apple, peach, and watermelon, but the data source is not welldocumented.

Projected Conclusions/Needs/Options. Curium, like americium, has not been intensive nor extensive enough to fully delineate the roles of contaminant form and biological/soil factors on speciation and bioavailability. However, like americium, it appears that overall plant availability is a factor of 10 or more greater than for plutonium.

\subsubsection{Thorium}

Environmental Behavior. Thorium likely exists in the environment in the IV valence state, and its chemistry is expected to mimic that of plutonium, except that plant uptake data do not support the assumption.

Thorium Concentration Ratios. Limited data are available for Th. That which exists deals exclusively with natural sources (Table 3.1). Greenhouse studies with Arostis shows CRs of $2 \mathrm{E}-4$ to $3 \mathrm{E}-3$ for shoot tissues and 0.01 to 0.12 for root tissues. This root accumulation pattern supports a hydrolytic behavior similar to plutonium. Results for blueberry are similar as to shoot CRs. Results for plant uptake adjacent to a fertilizer production plant in Spain show elevated CRs (0.076); this may be related to surface contamination. One report referenced by Carini (2001) shows a CR of 4.9E-4 for melon.

Projected Conclusions/Needs/Options. Overall, the data for Th is limited. However, it is likely that its behavior will be analogous to plutonium, since only the IV valence is possible.

\subsubsection{Beryllium}

Environmental Behavior. Very little is known of the environmental behavior of beryllium. Beryllium exists in soils at a level of approximately $0.3 \mathrm{ppm}$. Its concentration in plants ranges from 0.0006 to $0.04 \mathrm{ppm}$. It is a bone seeker in mammals and is toxic to both plants and animals. Its chemistry, $\mathrm{Be}^{+2}$, would indicate that it could be an analogue of group IIa elements (magnesium and calcium).

Beryllium Concentration Ratios. Only one study could be located (Table 3.1). This study by Tyler and Olsson (2001) is a greenhouse study conducted in Sweden with Arostis capillaris. Reported CRs were $1.6 \mathrm{E}-2$ to 0.09 and $3 \mathrm{E}-4$ to $1.6 \mathrm{E}-3$ for roots and shoots, respectively.

Projected Conclusions/Needs/Options. The general lack of understanding and data for beryllium would indicate a need for further work, should the source-term risks warrant investigations.

\subsubsection{Nickel}

Environmental Behavior. Nickel exists in the environment predominantly as the +2 ion, which can also be predicted to exist in the $\mathrm{Ni}(\mathrm{OH})^{+}$state. Global soil concentrations for nickel average 
$50 \mathrm{ppm}$; plant concentrations have been measured at 0.2 to $5 \mathrm{ppm}$, with accumulator plants accumulating orders of magnitude greater levels.

Nickel Concentration Ratios. Relatively few studies directed at CRs have been conducted, but nickel has been extensively studied in plants because it is an essential element, and it has a high absorption rate by plants. Tyler and Olsson (2001, Table 3.1) in a greenhouse study conducted in Sweden with Arostis capillaris, reported CRs of 0.46 to 1.39 and 0.13 to 0.29 for roots and shoots, respectively. In a study by Cataldo and Wildung (1978b) the relative plant availability of endogenous and amended soil nickel was evaluated. In these studies, the CR to the whole plant was 0.022 and 5.72 for endogenous and amended nickel, respectively. The plant distribution at maturity showed concentrations to be Pod and seed $>$ Stem $>$ Leaves, indicating an efficient uptake and transport system. In a subsequent study (Cataldo and Wildung 1978a), root transport studies showed uptake to occur using membrane mechanisms in place for $\mathrm{Cu}$ and $\mathrm{Zn}$.

Biochemical studies showed nickel to be organically complexed in the root and transported to the shoot tissues, with significant metabolism occurring post accumulation, as would be expected for an essential element or analogue (Cataldo et al. 1978a).

Projected Conclusions/Needs/Options. Nickel as an essential element and potential nutrient analogue and may require further study if radiological and/or chemical risk exists. Needs include plant CRs and chemical forms following metabolism.

\subsubsection{Niobium}

Environmental Behavior. Niobium is estimated to be present in surface soils at a level estimated at approximately $10 \mathrm{ppm}$. Plant levels are believed to be in the range of $0.3 \mathrm{ppm}$. $\mathrm{Nb}$ can exist in two valence states, +3 and +5 .

Niobium Concentration Ratios. Only one study could be located (Table 3.1). This study by Tyler and Olsson (2001) is a greenhouse study conducted in Sweden with Arostis capillaris. Reported CRs were 0.38 to 1.2 and 0.005 to 0.04 for roots and shoots, respectively. As the only data available, uptake rates are intermediate, and risk would reside ether in radiological considerations or in its moderate biological toxicity.

Projected Conclusions/Needs/Options. If $\mathrm{Nb}$ presents a potential risk, further study needs to be undertaken.

\subsubsection{Tin}

Environmental Behavior. Tin is found globally in soils at levels of approximately $4 \mathrm{ppm}$. Terrestrial plants have estimated tin concentrations of 0.2 to $6 \mathrm{ppm}$. A number of plant accumulators exist, and tin is not particularly toxic. Tin can exist in the +2 and +4 valence states, and likely exists as a cation.

Tin Concentration Ratios. The only plant CR data that could be located for tin was by Cataldo et al. (1978b). In this study, the relative plant availability of endogenous and amended soil tin was 
evaluated. In these studies, the reported CR values to the whole plant was $>1.1$ and 0.38 for endogenous and amended tin, respectively.

Projected Conclusions/Needs/Options. If tin presents a potential risk, further study needs to undertaken.

\subsubsection{Selenium}

Environmental Behavior. Selenium is present in surface soils at levels of approximately $0.4 \mathrm{ppm}$. Normal plant concentrations can range from 0.001 to $0.5 \mathrm{ppm}$. A number of plant accumulator species are known, and selenium is known to be chemically toxic in excess to both plants and animals. Selenium can exist in the $+4,+6$, and -2 valence states, but the +6 dominates with the dominant species being the $\mathrm{SeO}_{2}{ }^{-2}$ form.

Selenium Concentration Ratios. A study by Tyler and Olsson (2001) is a greenhouse study conducted in Sweden with Arostis capillaris. Reported CRs were 0.08 to 0.32 and 0.05 to 0.08 for roots and shoots, respectively (Table 3.1). As the only data available, uptake rates are intermediate, and risk would reside either in radiological considerations or in its moderate biological toxicity.

Projected Conclusions/Needs/Options. If selenium presents a potential risk, further study needs to undertaken.

\subsubsection{Silver}

Environmental Behavior. Very little is known concerning the radioecological behavior of silver.

Silver Concentration Ratios. A study by Tyler and Olsson (2001) is a greenhouse study conducted in Sweden with Arostis capillaris. Reported CRs were 0.85 to 0.89 and 0.01 to 0.06 for roots and shoots, respectively (Table 3.1). In a study by Cataldo and Wildung (1978b) the relative plant availability of endogenous and amended soil silver was evaluated. In these studies, the CR to the whole plant was 0.057 and 0.001 for endogenous and amended silver, respectively. The plant distribution at maturity showed concentrations to be Stem $>>$ Leaves $=$ Pod and seed, indicating poor mobilization and limited complexation capacity.

Projected Conclusions/Needs/Options. If silver presents a potential dose/risk concern, further study needs to undertaken.

\subsection{Irrigation Water-to-Plant Transfer}

The transfer of radionuclides from groundwaters via irrigation to plant foliage and subsequently the root zone follows a few basic premises. These are as follows:

1. The speciation of contaminants that exists at the point of water removal will dominate during the foliar exposure period. 
2. Irrigation runoff from foliage, which impacts the plant drip line and soils of the rhizosphere, will likewise dominate over a short period, subsequently coming to a dynamic chemical equilibrium within the soil, and this affects its availability to plants.

3. Elements/ions deposited to foliage can be retained by physical entrainment on the cuticular waxes/tricomes, chemical adsorption, and/or foliar absorption. This is totally dependent on the nature of the speciation.

4. During a typical 1- to 6-hour irrigation cycle, much if not most of the contaminants will be washed to soil.

5. Entrainment will be expected for micron and sub-micron particles, i.e., oxides and hydroxides, as well as low-solubility contaminants.

6. Adsorption and absorption will be controlled by the cationic and anionic nature of contaminants; anions are more easily absorbed than cations.

7. Contaminant retention following a wet deposition event (further uptake potential) is a function of particle size, solubility, and bioavailability. Cuticular structures remain somewhat wetted at all times.

There is unfortunately no indepth compilation of the rates of retention nor uptake of radionuclides into the plant via foliar contamination. Kinnersley and Scott (2001) undertook model parameterization for wet and dry deposition processes to plant surfaces. This theoretical parameterization is reasonable, but there is a nearly total lack of supporting data.

\subsubsection{Plant Mobility}

The generic agricultural database provides some insights into plant mobility. In very early work by Bukovac and Wittwer (1957), the relative importance of phloem transport of ions was evaluated (Table 3.2). Phloem transport is an essential aspect of both wet irrigation and dry deposition processes because foliar surfaces are an effective receptor for plant nutrients. However, only those ions that are phloem mobile can leave the aerial structure and move to other plant tissues. Those not absorbed internally and transported out, and they will remain associated with the contaminated structure until sloughing of waxes or removal by wind and/or rainfall.

Table 3.2 provides the published behavior of various elements with respect to phloem mobility and is updated based on various unpublished assessments of analogous behavior of elements of interest. Note that no phloem mobility/immobile does not mean that uptake into the receiving structure does not occur.

For our needs, it would appear that all of the radionuclides of interest, with the exception of nickel, are likely not phloem mobile. Therefore, if leaf or fruit contamination occurs via irrigation, any absorbed component will remain within the absorbing tissue. However, once again, this is an assumption, and phloem mobility needs to be quantified for many radionuclide species. 
Table 3.2. Mobility of Essential Elements in the Phloem of Plants, and Projected Analogue/Non Nutrient Ion Behavior. (C) indicates the normally organically complexed form required.

\begin{tabular}{|c|c|c|c|c|}
\hline Mobile & Chem Form & Intermediate & Chem Form & Immobile \\
\hline $\mathrm{K}$ & +1 & $\mathrm{Fe}$ & $+3(\mathrm{C})$ & $\mathrm{Li}^{+1}$ \\
\hline $\mathrm{Ru}$ & +1 & $\mathrm{Mn}$ & +2 & $\mathrm{Ca}^{+2}$ \\
\hline $\mathrm{Na}$ & +1 & $\mathrm{Zn}$ & +2 & $\mathrm{Sr}^{+2}$ \\
\hline $\mathrm{Mg}$ & +2 & $\mathrm{Cu}$ & $+2,+1$ & $\mathrm{Ba}^{+2}$ \\
\hline $\mathrm{P}$ & anionic & Mo & anionic & B anion \\
\hline $\mathrm{S}$ & anionic & & & \\
\hline $\mathrm{Cl}$ & +1 & & & \\
\hline \multicolumn{5}{|c|}{ Proposed Analogous Behavior } \\
\hline As & anionic & Co & +2 & $\mathrm{Ag}^{+1}$ \\
\hline $\mathrm{Ni}$ & $+1,+2$ & $\mathrm{Cr}$ & $+2(\mathrm{C})$ & $\mathrm{Cd}^{+1,+2}$ \\
\hline \multirow[t]{4}{*}{ Cs } & +1 & $\mathrm{Hg}$ & $\circ,+$ & $\mathrm{Pb}^{+2}$ \\
\hline & & $\mathrm{Sb}$ & anionic & $\mathrm{Sn}^{+2}$ \\
\hline & & $\mathrm{Tl}$ & +1 & \\
\hline & & $\mathrm{Sr}$ & & \\
\hline
\end{tabular}

\subsubsection{Potential for Foliar Absorption from Irrigation-Contaminated Surfaces}

The relative rates of absorption of elements from cuticular structures are difficult to quantify. First, absorptive capacity differs from root processes in that there are apoplastic/tricome routes of entry into the foliar interior, which are less discriminating (with respect to species discrimination) than for roots. Secondly, the transfer of individual elements is very dependent on chemical form and stability. For example, free cations and stable anions may be readily absorbed, while reactive or unstable species may not be absorbed, or absorbed to a lesser extent. The transfer process is basically a molecular level interfacial film flow. Thus, only molecularsized materials can move. Finally, refractory particles, i.e., oxides, carbonates, and hydroxides, of any size will not likely be transferred to the tissue interior unless a significant rate of solubilization is occurring, i.e., complexation agents in irrigation waters. These particles can and will, however, be entrained within the complex cuticular structures associated with most surface foliage.

While little data exist to demonstrate or quantify foliar absorption processes and particularly rates of transfer, a list of probable behaviors for priority radionuclides is given in Table 3.3.

This categorization is based on known behavior in soil/plant systems and likely chemical speciation in groundwaters. This listing is based on many assumptions, and it is clear that from a terrestrial plant standpoint and subsequent food-chain consideration that neptunium, technetium, and nickel are of high interest. Although much data exist for nickel and technetium, little is known of the foliar routes of entry for any of these elements. The intermediate category is 
questionable, but data would indicate that there is a need for study of particularly uranium, iodine, and americium. In the proposed Low Transfer category, little is known about the behavior of beryllium and niobium, and cesium needs to be reinvestigated.

Table 3.3. Probable Bioavailability/Cuticular Transfer of Selected Elements. This refers to foliar uptake, and not specifically phloem mobility and redistribution.

\begin{tabular}{||c|c|c||}
\hline High Transfer & Intermediate Transfer & Low Transfer \\
\hline $\mathrm{Np}$ & $\mathrm{Am}$ & $\mathrm{Pu}$ \\
\hline $\mathrm{Tc}$ & $\mathrm{Cs}$ & $\mathrm{Th}$ \\
\hline $\mathrm{Ni}$ & $\mathrm{U}$ & $\mathrm{Be}$ \\
\hline & $\mathrm{Cm}$ & $\mathrm{Nb}$ \\
\hline & $\mathrm{I}$ & $\mathrm{Sr}$ \\
\hline & $\mathrm{Se}$ & \\
\hline & $\mathrm{Ag}$ & \\
\hline & $\mathrm{Sn}$ & \\
\hline
\end{tabular}

\subsubsection{Constraining Factors in Irrigation and Run-Off Processes}

Contaminants contained within groundwaters or surface waters employed for irrigation of crops have two components. The soil component is likely well-established enough to evaluate risk for many of the priority elements. The foliar route remains an unknown, although there are certain constraints that limit risk. The typical irrigation cycle can be from one to many hours. Once plant surfaces are initially wetted, subsequent water flows to soil as run-off. The question is how much of a particular element can be entrained, adsorbed, and/or absorbed during an irrigation event. It is likely that following the initial saturation event, all subsequent waters/contaminants will be lost in run-off. This would likely be true for chemical forms having low to intermediate absorption rates and for elements with low adsorption rates, or with high absorption rates with limited leaf-surface binding sites. It may not be true for elements with exceptionally high bioavailability, as would possibly be the case for technetium and nickel.

\subsubsection{Available Data}

Horrill et al. (1995) used heather that was contaminated with fallout to study burning and leaching. Burning of heather at $550^{\circ} \mathrm{C}$ resulted in an ash that when leached with synthetic rainwater mobilized $24 \%$ of the cesium. For the hot burn, $660^{\circ} \mathrm{C}$, leaching removed $17 \%$ of the cesium. This would indicate that the contaminant form is important.

A study by Hinton et al. (1995), based on Chernobyl fallout, showed no significant impact of foliar absorption compared to root absorption. Further evaluation demonstrated that foliar absorption, root uptake, and entrainment of cesium-soil particles was greater for a loamy-sand site receiving condensation-type fallout than for a sandy site receiving fuel particles. While root uptake dominated the system, foliar absorption increased as root absorption decreased. 
Brambilla et al. (2002) investigated soil-fruit and leaf-to-fruit transfer of cesium, strontium, and zinc in tomato using a wet-deposition method with the following results: interception of $\mathrm{Zn}>>\mathrm{Cs}>\mathrm{Sr}$. Older plants have better interception efficiency than younger ones. Rates of transfer from soil-to-fruit and leaves-to-fruit indicate that zinc is phloem mobile, as is cesium, but to a lesser extent. The order of fruit contamination level following root uptake is $\mathrm{Cs}>\mathrm{Zn}>\mathrm{Sr}$. With early-stage foliar deposition, the order is the same; for later-stage deposition, the order remains the same, but most of the strontium results from direct fruit deposition. Redistribution to fruit following foliar deposition is greatest for cesium and less for zinc and strontium.

Baeza et al. (1999) evaluated the temporal kinetics of cesium and strontium accumulation from soil and foliage using turnip and broad bean. They demonstrated a time and plant-age dependency for foliar transfer; the closer the time of foliar contamination is to fruit or tuber harvest, the greater the efficiency of foliar contributions.

Zehnder et al. (1995) studied foliar absorption and transport of cesium and strontium. Strontium was only minimally absorbed and plant mobile. Cesium was well absorbed, transferred to berries ( $8 \%$ of applied dose), but the transfer declined as berries matured, indicating a redistribution as known to occur for potassium.

Malek et al. (2002) evaluated the foliar interception of cesium and strontium deposited at two distances from Chernobyl and representing close-in particles/condensation products, and furtherout condensation products. For the $3-\mathrm{km}(1.9-\mathrm{mi})$ site, cesium and strontium interception was $5 \mathrm{E}-4 \pm 4.2 \mathrm{E}-4$ and $0.02 \pm 0.03$, respectively; and for the $60-\mathrm{km}(37.3-\mathrm{mi})$ site, $18 \pm 9$ and $2.3 \pm 1.6$ for cesium and strontium, respectively. This indicates a significant difference in the foliar behavior of fallout having differing chemical forms.

Cataldo et al. (1981) evaluated the chemical forms of plutonium and americium deposited to foliage of bush bean. Foliar transfer rates to seeds and roots ranged from 9 to $427 \mathrm{E}-4 \%$ for aged refractory oxides and more soluble forms, respectively. Transfer rates were significantly affected by chemical form and relative humidity. In a subsequent study (Cataldo et al. 1981), the influence of particle size and chemical form was evaluated with respect to retention characteristics and simulated leaching. Particles with a mass median aerodynamic diameter (MMAD) of $<1 \mu \mathrm{m}$ are not readily dislodged from leaves at wind speeds of $\sim 400 \mathrm{~m} / \mathrm{min}$. Under conditions of simulated rainfall, weathering half-times range from 164 to 1000 days and are dependent on both particle size and initial solubility; retention was measured at 20 to $92 \%$.

Foliar interception, foliar absorption, transport, and leaching studies, while limited, tend to indicate that foliar contamination for at least some elements can be a significant added risk factor. Elements such as plutonium, americium, and cesium can be absorbed and transported to other plant structures. Data for many key radionuclides are not available and need to be determined.

\subsection{Summary of Plant Concentration Ratios, Processes, and Projected Needs}

In this review and assessment of selected radionuclides, we have attempted to assess needs with respect to both data and controlling factors. The constraint that is encountered is one in which 
we rely on radiological risk/dose for prioritization. In some cases, $\mathrm{CR}$ values are consistent with limited anticipated bounds (Th, $\mathrm{Pu}, \mathrm{Cs}, \mathrm{Sr})$; in others, there are unexpected excursions (Am, $\mathrm{Cm}$, $\mathrm{Np}, \mathrm{Tc}, \mathrm{U}, \mathrm{Ni}$ ), and for other elements, there is little or no data (Be, $\mathrm{Sn}, \mathrm{I}, \mathrm{Se}, \mathrm{Nb}, \mathrm{Ag}$ ).

Further complicating the normal radiological risk-estimation approaches is the growing database related to chemical toxicity in the food-chain related to chemical complexation and/or metabolic incorporation of some radionuclide species. This potential risk factor needs to be addressed.

The question of atmospheric deposition and the irrigation-water source-term appears to be more complicated than earlier believed and most certainly requires prioritization if risk-assessment models verify its role in contaminant transfer.

\subsubsection{Soil/Plant Concentration Ratios}

Based on this rather selective/ targeted review of the literature, several points are clear. First, CRs for individual radionuclides can be expected to vary with plant species and environmental/physicochemical conditions. Second, while the cumulative database for soil/plant $\mathrm{CR}$ values appears adequate for $\mathrm{Cs}, \mathrm{Sr}, \mathrm{Pu}$, and $\mathrm{Th}$, and possibly $\mathrm{Am}$ and $\mathrm{Cm}$, data related to $\mathrm{U}$ and $\mathrm{Np}$ need to be reinvestigated based on current knowledge of chemical behavior in the environment. This is indicated based on the elevated CR values for many studies. Similarly, there is substantial data for Tc and $\mathrm{Ni}$, but very little data for I, Sn, Se, Be, Nb, or Ag. The data for technetium shows a wide range in $\mathrm{CR}$ values, and this element represents one of the most environmentally mobile and bioavailable of all radionuclides. As noted, there is practically no plant transport data for many of the selected ions; these include I, $\mathrm{Sn}, \mathrm{Se}, \mathrm{Be}, \mathrm{Nb}$, or $\mathrm{Ag}$.

For a number of these elements, there is a secondary risk concern, namely significant changes in speciation once accumulated by the plant. For elements such as Tc, Ni, I, Ag, Se, Sn, and possibly several of the actinides, the very real potential exists for significant biocomplexation. Biocomplexation, where an element undergoes appropriate speciation and metabolism to form stable biomolecules, can be problematic in assessing risk to higher trophic levels. Additionally, at least two of these elements, uranium and curium, have been shown to be chemically toxic, and this is very likely related to biocomplexation.

\subsubsection{Irrigation-Water Source-Terms and Atmosphere-to-Plant Transfer}

The irrigation-water scenario has two interrelated components. First is the plant contact with, and bioaccumulation of, contaminants contained in the irrigation water, and second is the effect of irrigation or natural precipitation on the mobilization of foliar-deposited contaminants. From the limited literature/database available, it appears that the component processes may be more efficient than originally perceived. First, foliar retention of contaminants associated with drydeposition processes appear to be efficiently retained; in this instance, only highly soluble and bioactive compounds can or should be absorbed to some extent (technetium, iodine, nickel). However, in precipitation events, the normal wetting appears to mobilize many elements as discussed earlier, resulting in increased absorption, and in some cases, phloem transport and redistribution to other plant tissues, including fruit. 
In the irrigation water scenario, the dry deposition/precipitation scenario is complicated by providing an excess of water and thus substantial run-off from foliage to soil. As noted earlier, in this scenario, we can expect a steady-state type of dose, but not significant accumulation due to time constraints and contact times. However, based on dry deposition/wetting studies, it is likely that the irrigation process will significantly increase the absorption and possibly the distal transport of many elements under consideration.

\subsection{Section 3 References}

Arthur WJ, III. 1982. "Radionuclide Concentrations in Vegetation at a Solid Radioactive Waste-Disposal Area in Southeastern Idaho.” J. Environ. Qual. 11(3):394-399.

Baeza A, JM Paniagua, M Rufo, A Sterling, J Barandica. 1999. "Radiocesium and Radiostrontium Uptake by Turnips and Broad Beans Via Leaf and Root Absorption." Applied Radiat. and Isotop. 50:467-474.

Birch LD, and R Bachofen. 1990. "Effects Of Microorganisms on The Environmental Mobility Of Radionuclides.” In Soil Biochemistry, eds. J-M Bollag and G Stotzky, vol. 6. Marcel Dekker, Inc. NY.

Bovard P, A Grauby, and A Sass. 1968. "Chelating Effects of Organic Matter and Its Influence on the Migration of Fission Products." In Proceedings of Symposium: Isotopes and Radiation in Soil Organic-Matter Studies, p. 471-495. CONF-680725, STI/PUB-190 (CONF-680725), NSA, IAEA, Vienna.

Brambilla M, P Fortunati, and F Carini. 2002. "Foliar and Root Uptake of Cs, Sr and Zn in Processing Tomato Plants.” J. Environ. Rad. 60:351-363.

Bruno J, I Casas, and I Puigdomenech. 1988. "The kinetics of dissolution of $\mathrm{UO}_{2}$ (s) under reducing conditions. Radiochim. Acta. 44/45:11-16.

Bruno J, I Casas, and I Puigdomenech. 1991. "The Kinetics of Dissolution of $\mathrm{UO}_{2}$ Under Reducing Conditions and the Influence of an Oxidized Surface Layer (UO2+X): Application of a Continuous Flow-Through Reactor." Geochim. Cosmochim. Acta. 55:647-659.

Bukovac MJ, and SH Wittwer. 1957. "Absorption and Mobility of Foliar Applied Nutrients." Plant Physiol. 32:428-435.

Carini F. 2001. "Radionuclide Transfer from Soil to Fruit.” Environ. Rad. 52:237-279.

Cataldo DA, and RE Wildung. 1978a. "Nickel in Plants, I. Uptake Kinetics Using Intact Soybean Seedlings." Plant Physiol. 62:563-565.

Cataldo DA, and RE Wildung. 1978b. "Soil and Plant Factors Influencing the Accumulation of Heavy Metals by Plants." Environ. Health Persp. 27:149-159. 
Cataldo DA, TR Garland, and RE Wildung. 1978a. "Nickel in Plants: II. Distribution and Chemical Form in Soybean Plants." Plant Physiol. 62:566-570.

Cataldo DA, RC Routson, D Paine, and TR Garland. 1978b. Relationships Between Properties of Hanford Area Soils and the Availability of 134Cs and 85Sr for Uptake by Cheatgrass and Tumbleweed. PNL-2496, Pacific Northwest Laboratory, Richland, WA.

Cataldo DA. 1979. Behavior of Technetium and Iodine in a Hanford Sand and Associated Subsoil: Influence of Soil Aging on Uptake by Cheatgrass and Tumbleweed. PNL-2740, Pacific Northwest Laboratory, Richland, WA.

Cataldo DA, TR Garland, and RE Wildung. 1981. "Foliar Retention and Leaching of Submicron Pu and Am Particles.” J. Environ. Qual. 10:31-37.

Cataldo DA, RE Wildung, and TR Garland. 1983. "Root Absorption and Transport Behavior of Technetium in Soybean.” Plant Physiol. 73:849-852.

Cataldo DA, TR Garland, and RE Wildung. 1988. "Absorption, Distribution, and Chemical Fate of Np in Plants.” J.Agric. Food Chem. 36:657-662.

Cataldo DA, TR Garland, RE Wildung, and RJ Fellows. 1989. "Comparative Metabolic Behavior and Interrelationships of Tc and S in Soybean Plants." Health Physics 57:281-287.

Cline JF. 1981. "Aging Effects of the Availability of Strontium and Cesium to Plants." Health Phys. 41:293-296.

Cline JF, and EL Klepper. 1975. "Iodine-125 Accumulation in Plant Parts: Influence of Water Use rate and Stable Iodine Content of Soil." Health Phys. 28:801-804.

Cline JF, and WH Rickard. 1972. "Radioactive Strontium and Cesium in Cultivated and Abandoned Field Plots." Health Phys. 23:317-324.

Cline JF, and RG Schreckhise. 1987. "Comparative Plant Uptake of Pu-239 Added to Soil in Oxide Versus Nitrate Form." In: Environ, Res. on Actinide Elements. USDOE Conf.-841142.

Comar CL. 1965. "Movement of Fallout Radionuclides Through the Biosphere and Man." Ann. Rev. Nucl. Sci. 15:175-206.

Comar CL, RH Wasserman, and MM Nold. 1956. "Strontium-Calcium Discrimination Factors in the Rat." Proc. Soc. Exp. Biol. Med. 92:859.

Coughtrey PJ, MC Thorne, DC Jackson, CH Jones, and P Kane. 1983-1985. Radionuclide Distribution and Transport in Terrestrial and Aquatic Ecosystems, vols. 1 to 6. AA Balkema, Rotterdam, The Netherlands. 
Dehut JP, K Fonsny, and C Mytenaere. 1989. "Bioavailability of Tc Incorporated into Plant Material." Health Physics 57:263-267.

Denys S, G Echevarria, E Leclerc-Cessac, S Massoura, and J-L Morel. 2002. "Assessment of Plant Uptake of Radioactive Nickel from Soils." J. Environ. Radioact. 62:195-205.

Dreesen DR., MJ Williams, ML Marple, E.S Gladney, and DR Perrin. 1982. "Mobility and Bioavailability of Uranium Mill Tailings Contaminants." Envioiron. Sci. Technol. 16:702-709.

Entry JA, and LS Watrud. 1998. "Potential Remediation of 137-Cs and 90-Sr Contaminated Soil by Accumulation in Alamo Swithgrass." Water Air Pollu. 104:339-352.

Fircks von Y, K Rosen, L Sennerby-Forsse. 2002. "Uptake and Distribution of Cs and Sr in Salix Viminalis Plants. J. Environ. Rad. 63:1-14.

Fuhrmann M, MM Lasat, SD Ebbs, LV Kochian, and J Cornish. 2002. "Uptake of Cs-137 and Sr-90 from Contaminated Soil by Three Plant Species; Application to Phytoremediation." J. Environ. Qual. 31:904-909.

Garland TR, DA Cataldo, KM McFadden, RG Schreckhise, and RE Wildung. 1983. "Comparative Behavior of 99-Tc, 129-I, 127-I and 137-Cs in the Environment Adjacent to a Fuels Reprocessing Facility." Health Phys. 44:658-662.

Garland TR, DA Cataldo, and RE Wildung. 1981. "Absorption, Transport, and Chemical Fate of Pu in Soybean Plants." Agric. Food. Chem. 29:915-920.

Garten CT, Jr., EA Bondietti, JR Trabalka, RL Walker, and TG Scott. 1987. "Field Studies on the Behavior of Actinide Elements in East Tennessee." In Environmental Research on Actinide Elements, eds. JE Pinder III, JJ Alberts, KW McLeod, and RG Schreckhise, p. 109-119. CONF-841142 (DE86006713) U.S. DOE OHER Symposium Series 59.

Garten CT, Jr., FO Hoffman, and EA Bondietti. 1984. "Field and Greenhouse Experiments on the Fate of Technetium in Plants and Soil." Health Phys. 46:647-656.

Hanson WC, and FR Miera Jr. 1976. Long-Term Ecological Effects of Exposure to Uranium. LA-6269, Los Alamos Scientific Laboratory, Los Alamos, NM.

Hinton TG, M McDonald, Y Ivanov, N Arkhipov, A Arkhipov. 1995. "Foliar Adsorption of Resuspended Cs-137 Relative to Other Pathways to Plant Contamination." J. Environ. Rad. 30-15-30.

Hoffman FO, JW Huckabee, DW Lucas, CT Garten, TG Scott, RL Walker, PS Gouge, and CV Holmes. 1980. Sampling of Tc in vegetation and soils in the vicinity of gaseous diffusion facilities. Oak ridge, TN. ORNL/TM-7386, Oak Ridge National laboratory, Oak Ridge, TN. 
Hoffman FO, CT Garten, DW Lucas, and JW Huckabee. 1982. "Environmental Behavior of Tc in Soil and Vegetation: Implications for Radiological Assessment." Environ. Sci. Technol. 16:214-217.

Horrill AD, VH Kennedy, IS Paterson, and GM McGowan. 1995. "The Effect of Heather Burning on the Transfer of Radiocesium to Smoke and the Solubility of Radiocesium Associated with Different Types of Heater Ash." J. Environ. Rad. 29:1-10.

International Atomic Energy Agency (IAEA), International Union of Radioecologists. 1994. "Handbook of Parameter Values for the Prediction of Radionuclide Transfer in Temperate Environments." IAEA, Tech. Rep. Series No 364, Vienna, Austria.

Ibrahim SA, and FW Whicker. 1988. "Comparative Uptake of $U$ and Th by Native Plants at a U Production Site.” Health Phys. 54(4):413-419.

Kinnersley RP, and LK Scott. 2001. "Aerial Contamination of Fruit Through We Eposition and Particulate Dry Deposition.” J. Environ. Rad. 52:191-213.

Krijger GC, AV Harms, R Leen, TG Verburg, B Wolterbeek. 1999. "Chemical Forms of Tc in Tomato Plants:Tco4-, Tc-Cysteine, Tc-Glutathione, and Tc-Proteins.” Environ. Experim. Bot. 42:69-81.

Landa ER, LJ Hart Thorvig, and RG Gast. 1977. "Uptake and Distribution of Technetium-99 in Higher Plants." In Biological Implications of Metals in the Environment. Proceedings of the Fifteenth Annual Hanford Life Sciences Symposium at Richland, Washington, September 29October 1, 1975, p. 390-401. CONF-750959, U.S. Department of Energy, Washington, D.C.

Landeen DS, and RM Mitchell. 1986. "Radionuclide Uptake by Trees at a Radwaste Pond in Washington State." Health Phys. 50(6):769-774.

Langmuir D. 1978. "Uranium Solution-Mineral Equilibria at Low Temperatures with Application to Sedimentary Ore Deposits." Geochim. Cosmochim. Acta. 42:547-564.

Lindsay WL. 1979. Chemical Equilibria in Soils. John Wiley and Sons, NY.

Livens FR, AD Horrill, and DL Singleton. 1991. "Distribution of Radiocesium in the Soil-Plant Systems of Upland Areas of Europe." Health Physics 60:539-545.

Livens FR, AD Horrill, and DL Singleton. 1994. "The Relationship Between Concentration of $\mathrm{Pu}$ and Am in Soil Interstitial Waters and Their Uptake by Plants." Sc. Tootal Environ.

155:151-159.

Mahon DC. 1982. "Uptake and Translocation of Naturally-Occurring Radionuclides of the Uranium Series." Bull. Environ. Contam. Toxicol. 29:697-703. 
Malek MA, TG Hinton, SB Webb. 2002. "A Comparison of Sr-90 and Cs-137 Uptake by Plants Via Three Pathways at Two Chernobyl Contaminated Sites." J. Environ. Rad. 58: 129-141.

Martinez-Aguirre A, I Garcia-Orellana, M Garcia-Leon. 1997. "Transfer of Natural Radionuclides from Soils to Plants in a Marsh Enhanced by the Operation of Non-Nuclear Industries.” J. Environ. Rad. 35:149-171.

Menzel RG. 1963. "Factors Influencing the Biological Availability of Radionuclides for Plants." Federation Proc. 22:1398-1401.

Moffett D. and M Tellier. 1977. "Uptake of Radioisotopes by Vegetation Growing on Uranium Tailings." Can J. Soil Sci. 57:417-424.

Morton LS, CV Evans, G Harbottle, GO Estes. "Pedogenic Fractionation and Bioavailability of U and Th in Naturally Radioactive Spodosols." Soil Asc, Soc. Am. J. 65:1197-1203.

Mousny JM, and C Mytenaere. 1981. "Absorption of Tc by Plants in Relation to Soiltype, Contamination Level and Time." Plant Soil 61:403-412.

Nisbet AF, and RFM Woodman. 2000. "Soil-Plant Transfer Factors for Radiocesium and Radiostrontium in Agricultural Systems.” Health Physics 78: 279-288.

Nishita H, A Wallace, EM Romney, and RK Schultz. 1981. "Effect of Soil Type on the Extractability of Np, Pu, Am and Cm as a function of PH." Soil Sci.132:25-34

Paasikallio A, A Rantavaara, and J Sippola. 1994. "The Transfer of Cesium-137 and Strontium90 from Soil to Food Crops After the Chornobyl Accident." Sci. Tot. Environ. 155:109-124.

Price KR. 1972. Uptake of Np-237, Pu-239, Am-241 and Cm-244 from Soil by Tumbleweed and Cheatgrass. BNWL-1688, Battelle, Pacific Northwest Laboratories, Richland, WA.

Romney EM, HM Mork, and KH Larson. 1970. "Persistence of Plutonium in Soil, Plants, and Small Mammals.” Health Phys. 19:487-491.

Romney EM, A Wallace, JE Kinnear, and RA Wood. 1985. "Plant Root Uptake of Pu and Am." In The Radioecology of Transuranics and Other Radionuclides in Desert Ecosystems, eds. WA Howard, PB Dunaway, and RG Fuller, pp. 185-199. NVO-224 (DE86001243), U.S. DOE, Nevada Operations Office, Las Vegas, NV.

Routson RC, and DA Cataldo. 1977. Tumbleweed and Cheatgrass Uptake of 99Tc from Five Hanford Project Soils. BNWL-2183, Battelle_Pacific Northwest Laboratories, Richland, WA.

Routson RC, and DA Cataldo. 1978a. "A Growth Chamber Study of the Effect of Soil Concentration and Plant Age on the Uptake of Sr and Cs by Tumbleweed." Commun. in Soil Sci. and Plant Anal. 9(3):215-229. 
Routson RC, and DA Cataldo. 1978b. "Accumulation of Tc by Tumbleweeds and Cheatgrass Grown on Arid Soils.” Health Physics 34:685-690.

Schreckise RG, and JF Cline. 1980. "Comparative Uptake and Distribution of Plutonium, Americium, Curium and Neptunium in Four Plant Species.” Health Physics 38:817-824.

Schuller P, C Lovengreen, and H Handl. 1993. "137Cs Concentration in Soil, Prairie Plants, and Milk from Sites in Southern Chile." Health Phys. 64:157-161.

Schultz RK, GA Tompkins, L LevenThal, and KL Babcock. 1976. "Uptake of Plutoium and Americium bu Barley from Two contaminated Nevada Test Site Soils." J. Environ. Qual. 5:406-410.

Sheppard SC, and WG Evenden. 1988. "Critical Compilation and Review of Plant/Soil Concentration Ratios for Uranium, Thorium and Lead.” J. Environ. Radioactivity 8:255-285.

Sheppard SC, and WG Evenden. 1992. "Bioavailability indices for Uranium: Effect of Concentration in Eleven Soils." Arch. Environ. Contam. Toxicol. 23:117-124.

Sheppard SC, WG Evenden, and AJ Anderson. 1992. "Multiple Assays of Uranium Toxicity in Soil.” Environ. Toxicol. Water Qual. 7:275-294.

Sheppard MI, TT Vandergraaf, DH Thibault, and JA Keith Reid. 1983. "Technetium and Uranium: Sorption by and Plant Uptake from Peat and Sand.” Health Phys. 44(6):635-643.

Shinonaga T, MH Gerzabek, F Strebl, Y Muramatsu. 2001. “Transfer of Iodine from Soil to Cereal Grains in Agricultural Areas of Australia.” Sc. Total Environ. 267:33-40.

Simon SL, JC Graham, SD Terp. 2002. "Uptake of 40K and 137 Cs in Native Plants of the Marshall Islands.” J. Environ. Rad. 59:223-243.

Singh S, R Malhotra, J Kumar, B Singh, and L Singh. 2001. Rad Measurem. 34:427-431.

Skarlou V, C Nobeli, J Anoussis, C Haidouti, E papanicolaou. 1999. "Transfer Factors for Olive and Orange Trees Grown on Different Soils.” J. Environ. Rad. 45:139-147.

Stevenson FJ, and A Fitch. 1986. "Chemistry of Complexation of Metal Ions with Soil Solution Organics," eds. PM Huang and M Schnitzer, In Interactions of Soil Minerals with Natural Organics and Microbes, SSSa Special Publication No. 17. Soil Sci Soc. of Am., Inc. Madison, WI.

Thomas JM, LL Cadwell, DA Cataldo, TR Garland, and RE Wildung. 1984. "Concentration of Orally Administered and Chronically Fed 95mtc in Japanese Quail Eggs." Health Phys. 46(3):657-663. 
Tome ER, DG Flag, and FD Riddle. 2001. "The Behavior of Natural Thorium Associated with Granitic/Alluvial Soils." J. Envioron. Rad. 52:175-189.

Tyler G, and T Olssen. 2001. "Plant Uptake of Major and Minor Mineral Elements as Influenced by Soil Acidity and Liming." Plant and Soil 230:307-321.

Vidal M. 2001. "Soil-and Plant-Based Countermeasures to Reduce Cs-137 and Sr-90 Uptake by Grasses in Natural Meadows: the REDUP Project." J. Environ. Rad. 56:139-156.

Voight G, G Prohl, and H Mueller. 1991. "Experiments on the Seasonality of Cesium Translocation in Cereals, Potatoes, and Vegetables." Radiat. Environ. Biophys. 30:295-304.

Wallace A, EM Romney, and RA Wood. 1971. "Cycling of Stable Cesium in a Desert Ecosystem.” In Radionuclides in Ecosystems, ed. DJ Nelson, p. 183-186. Oak Ridge, TN. USAEC CONF-710501-P1, Washington, D.C.

White GC, TE Hakonson, and AJ Ahlquist. 1981. "Factors Affecting Radionuclide Availability to Vegetables Grown At Los Alamos." J. Environ. Qual. 10(3):294-299.

Wildung RE, DA Cataldo, and TR Garland. 1986. "Volatilization of Iodine from Soils and Plants." In Speciation of Fission and Activation Products in the Environment, eds. Ra Bulman and JR Cooper, Elsevier Applied Science Publishers, NY, pp. 243-249.

Wildung RE, TR Garland and DA Cataldo. 1977. "Accumulation of Technetium by Plants." Health Physics 32:314-317.

Wilson DO, and JF Cline. 1966. "Removal of Plutonium-239, Tungsten-185, and Lead-210 from Soils." Nature 5026:941-942.

Zehnder HJ, P Kopp, J Eikenberg, U Feller, JJ Oertli. 1995. "Uptake and Transport of Cs and Sr Into Grapevines After Leaf Contamination.” Radiat. Phys. Chem. 46:61-69. 


\subsection{Food Animal Transfer Coefficients}

\subsection{Introduction}

A literature review was performed on radionuclide uptake data of animal products. For this task, transfer coefficients were reviewed, evaluated, and compiled for cow milk, sheep milk, goat milk, beef, sheep meat (mutton and lamb), goat meat, pork, poultry and eggs. The emphasis of this review was on transfer coefficients from primary animal experiments that provided data from which transfer coefficients have been developed. Experiments designed to obtain complete data on radionuclide concentration of the food product (e.g., milk, meat, egg) and the radionuclide intake of the animals (concentration in the feed and the amount of feed consumed) are the most desirable for developing transfer coefficients. Alternatively, studies of acute oral ingestion of radionuclides, where the precise radionuclide intake and its concentration in the food product is known, may provide basic information. Less valuable results are from data derived from radionuclide concentrations of food products without a known relationship to intake, information regarding stable elements, transfer data of related elements, and collateral data from another species.

Several programs have developed predictive models for evaluating risk from various radionuclides using radionuclide transfer coefficients reported in the literature. These works include results documented in the following reports by $\mathrm{Ng}$ (1982), $\mathrm{Ng}$ et al. (1982a), $\mathrm{Ng}$ et al. (1982b), Coughtrey (1990), Kennedy and Strenge (1992), and IAEA (1994). The early publications are fairly complete with regard to the world-wide fallout through the 1970s but obviously do not include data collected after the Chernobyl accident in 1986. The 1994 IAEA report was used as the primary reference for this evaluation because of its completeness, and it represents the most recent evaluation of the available information including much of the Chernobyl data. For many nuclides, reference is made in this report to data from other reviews, such as the works of $\mathrm{Ng}$ or Coughtrey. In many cases, data included in the various reports have a common primary source, and it is unclear whether all primary data were revisited in subsequent evaluations. The uncertainties associated with the transfer coefficients of the various radionuclides derived by these methods are not always documented.

A discussion of the difficulties associated with the development of transfer coefficients and their use is addressed. Many of the examples used come from the literature on ${ }^{137} \mathrm{Cs}$ or ${ }^{131} \mathrm{I}$ because of the paucity of data for other radionuclides.

\subsection{Transfer Coefficients}

The transfer coefficient is widely used in the literature to predict the transfer of radionuclides to animal food products, usually for the purpose of predicting relative risk for humans. However, other relationships have been used for this purpose in the past. Early work developed the O-R to predict the transfer of ${ }^{90} \mathrm{Sr}$ uptake by milk (Comar et al. 1961; Comar et al. 1966). In this sense, the O-R is described as the ratio of $\mathrm{Sr}$ to $\mathrm{Ca}$ in the milk following consumption of ${ }^{90} \mathrm{Sr}$ -

contaminated feed. Likewise, the $\mathrm{Cs} / \mathrm{K}$ ratio was used to describe the uptake of ${ }^{137} \mathrm{Cs}$ in milk, 
assuming that the relationship would be similar for cesium and potassium as for strontium and calcium.

Ward and colleagues first used the transfer coefficient to describe the relationship between ${ }^{137} \mathrm{Cs}$ in animal feed and its concentration in the milk of dairy cows (Ward and Johnson 1965; Stewart et al. 1965; Ward et al. 1967; Johnson et al. 1968). They subsequently described the validation of this term as conceived (Ward and Johnson 1986). These researchers found that expressing

${ }^{137} \mathrm{Cs}$ relationships in milk as the $\mathrm{Cs} / \mathrm{K}$ ratio or as total ${ }^{137} \mathrm{Cs}$ output did not satisfactorily explain the variations or describe the proper relationships observed in the ${ }^{137} \mathrm{Cs}$ milk data from dairy studies using various forms of feed. To address this problem, Ward and colleagues expressed their results as a ratio of the daily ${ }^{137} \mathrm{Cs}$ intake $\left(\mathrm{Bq} /\right.$ day) to the concentration of ${ }^{137} \mathrm{Cs}$ per liter of milk $(\mathrm{Bq} / \mathrm{L})$. This term was used to successfully describe the relationship of ${ }^{137} \mathrm{Cs}$ levels in feed and milk under varying environmental management conditions. Subsequently, this approach was found to provide a convenient method to describe the relationship between ${ }^{137} \mathrm{Cs}$ in feed and meat products (Johnson et al. 1969).

This relationship $\left(\mathrm{F}_{\mathrm{m}}\right)$ has subsequently been expressed in the literature by the following equation:

$$
\mathrm{F}_{\mathrm{m}}(\mathrm{d} / \mathrm{L})=\frac{\text { Radionuclide Milk Concentration }(\mathrm{Bq} / \mathrm{kg})}{\text { Feed Conc. }(\mathrm{Bq} / \mathrm{kg}) \times \text { Feed Intake }(\mathrm{kg} / \text { day })}
$$

Since the inception of this concept, transfer coefficients have been applied to many of the radionuclides; nevertheless, Ward and Johnston (1986) cautioned regarding the general applicability of the use of transfer coefficients for a wide number of radioelements and animal species. Others argue about the use and abuse of transfer coefficients, but according to Shaw (2001), "no one has yet come up with a better idea" for expressing this relationship.

\subsection{Absorption}

The absorption of radionuclides from the gastrointestinal tract is probably the most important factor for determining the uptake into animal food products, specifically milk, eggs, meat, and poultry. Absorptive processes of many elements have been extensively studied (Underwood 1976; Harrison 1991). The absorption of various elements from the gastrointestinal tract is dependent on mechanisms specific for each element and is generally controlled by these mechanisms. Absorption of the essential elements is controlled by element-specific absorptive mechanisms. Most radionuclides of interest are non-essential for animal survival. In some cases, absorption of non-essential elements may be via mechanisms developed for the absorption of essential elements. Studies have shown that the actinide series radionuclides $(\mathrm{Th}, \mathrm{Np}, \mathrm{Pu}$, $\mathrm{Am}$, and $\mathrm{Cm}$ ) use the iron-transport protein transferrin for transfer in the circulatory system (Harrison 1991) and probably are absorbed via common iron-transport systems.

Absorption can be measured by the difference between daily intake of a radionuclide and the fecal excretion, called apparent absorption, or by the proportion of the radionuclide actually transferred across the gut wall, called true absorption. True absorption of radionuclides across the gastrointestinal tract is generally not determined in the derivation of absorption factors or 
transfer coefficients. Apparent absorption does not account for endogenous secretion of radionuclides that are initially absorbed then secreted back into the intestinal tract and eliminated in the feces or for elements that may be held up in intestinal cell but never transferred into the circulation. The latter has been most commonly observed in the very young. Studies by Mayes et al. (1992) and Beresford et al. (1992) suggest that knowledge about the influence of factors such as age or chemical form can be more accurately defined by having values for true absorption.

\subsection{Homeostatic Control}

Homeostatic control via major routes allows the animal to regulate the tissue content of the various elements taken into the body, mostly via ingestion. These control systems include gastrointestinal absorption, urinary excretion, tissue deposition (storage pools or organ uptake such as the thyroid), secretion into milk, and endogenous excretion via feces. Some radionuclides have dietary essential stable isotopes (such as iodine) or analogues (such as $\mathrm{Ca}$ in the case of Sr), which are under homeostatic control by the animal. For other nuclides, control may be by the mechanisms controlling other essential elements. The intestine, thyroid gland, and mammary gland all have unique mechanisms for controlling many elements. For elements that are homeostatically controlled, the uptake and excretion is set to maintain the plasma or milk concentration. In this case, the transfer coefficient will not be constant over a wide range of conditions, and milk or tissue concentration may not vary as the intake changes. An increase in feed concentration of a radionuclide may not equate to an increase in tissue concentration. For elements that are absorbed and not homeostatically controlled, accumulation could more accurately reflect the feed intake.

\subsection{Equilibration}

One assumption made for a valid transfer coefficient is that the radionuclide be allowed to reach or at least approach a steady state or equilibrium in the tissue when sampled or at slaughter. This requires a steady intake over the period being studied. This requirement is met most often in long-term feeding experiments. Single dosing experiments and some short-term experiments do not meet this requirement, and the resulting value may underestimate the true transfer coefficient. Many transfer coefficients have been derived from short-term acute experiments by extrapolating the data for 100 days or for sufficient time to approach equilibrium (Coughtrey 1990; Beresford et al. 2000).

\subsection{Chemical/Physical Form}

The rates of absorption of the elements are dependent on chemical form and usually are associated with solubility. The chemical form of the radionuclide definitely contributes to the variability observed in transfer-coefficient data. Comparisons of ${ }^{238} \mathrm{Pu}$ citrate and dioxide showed a 10-fold increase in the uptake in cow milk and beef (Stanley et al. 1975). Transfer in poultry was reported to be greater from the citrate form of ${ }^{238} \mathrm{Pu}$ compared to the oxide form (Sutton and Mullen 1977). Absorption of ionic ${ }^{137} \mathrm{Cs}$ in weaned lambs was approximately twice as great as absorption of fallout ${ }^{137}$ Cs from Chernobyl (Moss et al. 1989). 
Ward et al. (1989) found that the dairy-milk transfer coefficient for Chernobyl fallout was significantly less than that of world wide fallout and suggested that this was due to the physical/chemical differences of the fallout.

It has been shown for Cs that transfer coefficients are greater from root-plant uptake compared to foliage deposition. The ${ }^{137} \mathrm{Cs}$ contained in plants from soil uptake resulted in transfer coefficients that were greater $\left(1.410^{-2}\right)$ than that from worldwide fallout $\left(2 \times 10^{-3} \mathrm{~d} / \mathrm{L}\right)$ or Chernobyl fallout $\left(4 \times 10^{-3} \mathrm{~d} / \mathrm{L}\right)$ by an order of magnitude (Ward et al. 1989).

The radionuclides can exist in multiple form in the environment. The oxide forms are usually least bioavailable, and the ionic forms, such as the chlorides and sulfates, are more soluble and more available to the animal. Certain organometals may also efficiently absorbed. Studies comparing transfer coefficients for different chemical forms of the radionuclides in foodproducing animals are few.

\subsection{Isotopic Form}

The isotopic form of the radionuclide is generally assumed not to be a factor in determining the transfer coefficients for animal products. Ward et al. (1989) determined concentrations of ${ }^{134} \mathrm{Cs}$ and ${ }^{137} \mathrm{Cs}$ in the milk of cows consuming contaminated forage in Hungary after the Chernobyl accident and found no difference between the two isotopes. Similar results were reported by Fabbri et al. (1994) and Voors and Van Weers (1989) for milk from cows ingesting contaminated feed from Chernobyl.

It is well known that large amounts of stable I can reduce the transfer of ${ }^{131}$ I from the plasma to the milk in various animals and that ${ }^{131}$ I transfer is dependent on stable I concentration of the diet (Lengemann and Comar 1964; Crout et al. 2000; Voigt et al. 1994). The major regulating mechanism for I is hormonal control by the thyroid gland. Little data were found comparing the relationship between ${ }^{131} \mathrm{I}$ and ${ }^{129} \mathrm{I}$ with regard to transfer coefficients. Handl and Pfau (1989) investigated the transfer of ${ }^{129} \mathrm{I}$ to milk from cows fed hay labeled with ${ }^{129} \mathrm{I}$ via root uptake and concluded that the transfer coefficient of ${ }^{129} \mathrm{I}\left(2.4 \times 10^{-3} \mathrm{~d} / \mathrm{L}\right)$ was essentially the same as they obtained for Chernobyl ${ }^{131}$ I fallout $\left(2.6 \times 10^{-3} \mathrm{~d} / \mathrm{L}\right)$ (Handl and Pfau 1987). It is probably safe to assume that for animal products, the transfer coefficients of these two isotopes would be the same under normal conditions of stable I intake (Crout et al. 2000). The many studies done do not suggest a difference between stable iodine and ${ }^{131} \mathrm{I}$. However, more data for ${ }^{129}$ I would add confidence to this conclusion.

On the other hand, the transfer coefficients of Tc appear to depend on the isotope form. Johnson et al. (1988) and Ennis et al. (1988a) reported for goat milk that the transfer coefficient for ${ }^{99} \mathrm{Tc}$ was greater than that of ${ }^{95 \mathrm{~m}} \mathrm{Tc}$ and ${ }^{99 \mathrm{~m}} \mathrm{Tc}$. Furthermore, the transfer coefficient of ${ }^{95 \mathrm{~m}} \mathrm{Tc}$ was greater than that of ${ }^{99 \mathrm{~m}} \mathrm{Tc}$ for both goat and cow milk. There is no stable carrier for Tc, and the transfer is inversely proportional to the specific activity. This phenomenon was attributed to a slower rate of reduction of the lower specific activity isotope (pertechneate) in the rumen coupled with the differential half-lives of the isotopes. The common assumption that short-lived radionuclide tracer experiments may be used to predict the behavior of long-lived isotopes 
appears not to be applicable in the case of carrier-free isotope studies. It is expected that Tc transfer coefficients for meat and possibly eggs would also be influenced by specific activity.

The transfer of ${ }^{238} \mathrm{Pu}$ to the muscle of cattle was nearly an order of magnitude greater than that found for ${ }^{239 / 241} \mathrm{Pu}$ (Gilbert et al. 1989). Isotopic effects would not be expected for radionuclides with isotope carriers, but further study of isotopes without stable carriers such as Np would be of interest.

\subsection{Diet}

The content of the diet is a factor affecting the transfer coefficient of radionuclides. Diets high in fiber reduced transfer coefficients for ${ }^{137} \mathrm{Cs}$ whereas diets low in fiber increased transfer coefficients for ${ }^{137} \mathrm{Cs}$ provided from the same source (Stewart et al. 1965; Johnson et al. 1968). Undigested fiber particles adsorb increasing amounts of ${ }^{137} \mathrm{Cs}$ as the fiber content of the diet increases, resulting in a decreased absorption across the intestine. Similar results were obtained for ${ }^{137} \mathrm{Cs}$ transfer coefficients in a study of cows consuming forage cut close to the ground (low stubble height, $50 \mathrm{~mm}$ [2 in.]) or high cut stubble height $(150 \mathrm{~mm})$ (Bertilsson et al. 1988). Higher fiber or higher clay in the low stubble height forage could be factors reducing the transfer. Clay in the diet has been found to adsorb ${ }^{137} \mathrm{Cs}$, thereby reducing absorption and lowering the transfer coefficient.

The Ca level of the diet is known to influence the transfer coefficients of ${ }^{90} \mathrm{Sr}$. The $\mathrm{Ca}$ requirement of milk-producing animals varies with several factors, including milk production, stage of lactation, milk yield, and others. The transfer of ${ }^{90} \mathrm{Sr}$ to milk follows that of $\mathrm{Ca}$ and is strongly homeostatically controlled by $\mathrm{Ca}$. The Ca content of the pasture was possibly a factor in a lower transfer coefficient for ${ }^{90} \mathrm{Sr}$ in the milk of cows grazing alpine pastures compared to lowland pastures (Gastberger et al. 2001). Transfer coefficients for ${ }^{90} \mathrm{Sr}$ are not constant over a wide range of conditions, and a single value is unlikely to be valid (Howard et al. 1997).

The interference of dietary components of the diet is well known and has been extensively studied for a wide range of dietary elements. These interactions will certainly play a role in influencing the uptake of radionuclides into food products (Underwood 1976).

\subsection{Estimates of Radionuclide Intake}

The accuracy of the daily radionuclide intake is essential for estimating radionuclide transfer coefficients. Transfer-coefficient data have been estimated in hundreds of studies of various radionuclides using many animal species under a large number of experimental designs. A major component of the transfer coefficient is the amount of nuclide consumed, which includes measurement of the concentration of the feed and the amount of feed consumed. Many animal studies have been designed such that the actual feed being evaluated was used in the study. These include studies of contaminated hay, silage, or green chop feed for which accurate daily intake could be measured, and the concentration could be determined. For grazing studies, various methods have been used to obtain an estimate of the daily intake, such as sampling the grazing area and then estimating the percent grazed, or estimating intake from nutrient requirement or body weight. Non-absorbable or other marker techniques, such as cerium, 
chromium oxide, and alkane are also used (Sasser and Hawley 1966; Mayes and Lamb 1989; Gastberger et al. 2001). Transfer coefficients determined for some studies are based on estimated feed intakes from the literature for a particular species. In some cases, where nuclide intake is not available, transfer coefficients have been calculated from tissue concentrations using nuclide analysis of feed not directly consumed by animals for which the tissue concentrations were obtained. These methods of determining radionuclide intake could cause appreciable error in the resultant transfer coefficients.

Kirchner (1994) substantially reduced the variability of ${ }^{131} \mathrm{I}$ and ${ }^{137} \mathrm{Cs}$ in his compilation of transfer coefficients in the grass-cow-milk pathway from Chernobyl fallout by selectively using only studies for which measurements of forage intake and radionuclide concentration were directly applicable to the milk concentration of a particular study.

\subsection{Age}

In general, the absorption of elements from the gastrointestinal tact is enhanced in the young compared to adults (Sullivan et al. 1984). This includes monogastric and ruminant species. Data regarding transfer coefficients for the young food-producing animal are sparse, and transfer coefficients have generally not been established separately for adults and young food-producing animals for most radionuclides.

In lambs (from 11 to 59 weeks) fed ${ }^{137}$ Cs-contaminated ewe milk or ryegrass, the apparent absorption declined with age whereas true absorption appeared not to change with advancing age (Mayes et al. 1992). This difference may be due to the prolonged adherence of radionuclides in the intestinal tract of the young. Age differences previously reported in transfer-coefficient values may not be entirely the result of differences in absorption.

Age at exposure is likely not to be a major factor for milk or beef products of animals exposed when young because of the long time span between exposure and the utilization of the food product. However, if the interval between exposure as a young animal and slaughter is short, such as for veal, lamb, or poultry products, transfer coefficients could be greater for these products than expected for adults. For example, the International Atomic Energy Agency (IAEA) estimates for Pu and Am in veal and lamb is nearly 2-fold less than those for beef and mutton.

\subsection{Geographical Location}

Few data are available to compare transfer coefficients of most radionuclides at various geographical locations for food-producing animals. However, there are data suggesting that geography may be an important source of variability. There is general agreement that transfer coefficients for ${ }^{137} \mathrm{Cs}$ from Chernobyl fallout are less than those generally calculated for worldwide fallout (Ward et al. 1989; Kirchner 1994). Although the reason for this difference is not clear, one explanation offered is different physical-chemical factors resulting from site specific issues, such as rainfall, soil type, different amounts of re-suspension on plants, and uptake from soil. 
Worldwide fallout of ${ }^{137} \mathrm{Cs}$ in Florida milk was significantly greater than that generally observed in other parts of the United States (Porter et al. 1966; Ward et al. 1989). This difference has been attributed to the high sand content of Florida soil, which allowed for greater uptake by the plant material (alfalfa, citrus pulp) eaten by the cows. Transfer coefficients for milk ${ }^{137} \mathrm{Cs}$ increased by an order of magnitude when cows were fed green-chop grown after cessation of airborne deposition of Chernobyl fallout (Ward et al. 1989). Thus, this increase is attributed to ${ }^{137} \mathrm{Cs}$ incorporation into the plant from soil uptake in a more soluble form rather than deposition directly on the plant foliage or adhered soil particles. For less soluble radionuclides, the difference between foliage deposition and root uptake may be less apparent.

Calculated ${ }^{137} \mathrm{Cs}$ milk-transfer coefficients from Chernobyl fallout for India and Japan are greater than generally observed for Europe (Ward et al. 1989). This difference may be the result of a more soluble form of the Cs or a greater proportion of the plant content from soil uptake in a more soluble form.

Transfer coefficients of ${ }^{137} \mathrm{Cs}$ tended to be greater in the milk of cows grazing alpine pastures compared to lowland pastures. These results could be explained by the high uncertainty of the plant contamination because of the non-uniform nature of the alpine vegetation (Gastberger 2001).

\subsection{Soil and Water as Sources of Intake}

Ingestion of soil by grazing animals may occur because of adherence of soil particles to forage or as a result of animals eating soil. The amount of soil adhering to vegetation, and thus the amount of soil ingested by grazing animals, varies depending on the soil type, season and weather condition, stocking rate, and plant-growing rate. The amount of soil ingested also depends on animal species.

Soil ingestion was reported to be the principle source of $\mathrm{Pu}$ and Am intake by cattle grazing contaminated range land with daily intakes of nanocurie levels of Pu and Am (Blinco et al. 1981). For vegetation collected at two sites (Sellafield Reprocessing Plant and following the Chernobyl accident), soil comprised up to $92 \%$ and $63 \%$ of the ${ }^{137} \mathrm{Cs}$. Practically all of the ${ }^{238 / 240} \mathrm{Pu}$ on vegetation samples was associated with the soil (Beresford and Howard 1991). In another report, Cooke et al. (1996) estimated for two soils (one at Sellafield and a lowland organic soil artificially contaminated) that the availability of soil-associated ${ }^{137} \mathrm{Cs}$ following ingestion by sheep could be as much as $20 \%$ of that from incorporation in vegetation and that availability was much less from the lowland organic soil.

It was estimated that soil accounted for up to $60 \%$ of the ingested ${ }^{137} \mathrm{Cs}$ by cattle (Sumerling et al. 1984). Transfer coefficients for cattle fed forage where the soil comprised only $5 \%$ of the ${ }^{137} \mathrm{Cs}$ was greater than those consuming forage that had a high percent of the ${ }^{137} \mathrm{Cs}$ associated with the soil.

Transfer coefficients were obtained for $\mathrm{Cs}$ and $\mathrm{Sr}$ in the milk of sheep fed sandy topsoil collected near Chernobyl (Assimakopoulos et al. 1993a; Assimakopoulos et al. 1995). The values obtained were 0.026 and $0.041 \mathrm{~d} / \mathrm{L}$ for ${ }^{137} \mathrm{Cs}$ and ${ }^{90} \mathrm{Sr}$, respectively. On the other hand, transfer- 
coefficient values for sheep milk from Chernobyl ${ }^{137} \mathrm{Cs}$ were only $3.72 \times 10^{-4}$ and $6.11 \times 10^{-4} \mathrm{~d} / \mathrm{L}$ for two clay soils of 11 and 16\% clay, respectively (Belli et al. 1993). Soil ingestion is a significant pathway for elements to be incorporated into grazing animals (Thornton and Abrahams 1983), but the bioavailability of most radionuclides from soil has not been examined (Zach and Mayoh 1984).

Further studies are needed on the importance of soil contamination in the animal diet and on the uptake of various radionuclides associated with the ingestion of soil.

Experimental data examining the transfer coefficients from water to animal products are rare. If contaminated, the drinking-water intake by animals and radionuclide concentration would need to be determined. The ingestion of radionuclides from drinking water may be small for widespread contamination, but local contamination could alter this scenario.

Woodman and Nisbet (1999) predicted Cs and Sr transfer coefficients for drinking water of foodproducing animals. Cesium values of $0.005,0.03,0.5$, and $4.5 \mathrm{~d} / \mathrm{kg}$ were estimated for milk, beef, lamb-pork-poultry, and laying hen, respectively. Values for Sr were one to two orders of magnitude smaller.

For humans, the intake of uranium isotopes occurred mainly with water (Pietrzak-Flis et al. 2001). Biosphere modeling of the drinking water pathway for 26 radionuclides for Yucca Mountain found that the contribution to the total flux dose was less than $10 \%$ of the total for most radionuclides (Watkins et al. 1999). The fraction of ${ }^{234 / 238} \mathrm{U}$ absorbed was estimated in the range of $2 \times 10^{-3}$ to $1.5 \times 10^{-2}$ in humans whose source of $U$ was from drinking water (Harrison 1991).

\subsection{Transfer Coefficients for Specific Radionuclides in Food-Producing Animals}

Summary tables of animal food-transfer coefficients are listed in Table 4.1 through Table 4.9. Data in the tables come primarily from experimental animal results. Model prediction data listed in the IAEA handbook are included for each radionuclide for comparison, and occasionally other predictive data are included where experimental data are lacking. For many radionuclides, there is interesting and extending literature regarding absorption and tissue concentration, but most sources are not useful for deriving accurate transfer coefficients.

\subsubsection{Beryllium}

Very little information is available on the behavior of Be in the sense of transfer to food products. The transfer of a single dose of ${ }^{7} \mathrm{Be}$ (carrier-free $\left.\mathrm{BeCl}_{2}\right)$ to the milk of dairy cows was about $0.002 \%$ of the total dose with a peak of $0.00005 \% / \mathrm{L}$ at 28 hours after dosing (Mullen et al. 1972). Only about $1 \%$ was absorbed from the GI tract, but results of intravenous administration show that most was excreted in the urine and only $1 \%$ in milk. Redistribution at 454 hours was greatest in bone. No transfer coefficients for either milk or meat have been predicted from these data. Further studies are needed to evaluate Be transfer to animal foods. 


\subsubsection{Nickel}

Limited data are available on transfer coefficients of $\mathrm{Ni}$ for animal products. Estimates from Cramp et al. (1990), based on literature reviews, of $1.6 \times 10^{-2} \mathrm{~d} / \mathrm{L}$ and $5 \times 10^{-3} \mathrm{~d} / \mathrm{kg}$ were used by IAEA for cow milk and beef, respectively. It is generally accepted that the body does not retain great amounts of $\mathrm{Ni}$, except for the kidney and bone accumulation. High doses of Ni to rats resulted in a substantial accumulation of $\mathrm{Ni}$ in their nursing offspring through the milk (Dostal et al. 1989). No primary data were found from which estimates of transfer coefficients could be developed for milk or the meat of sheep and goats nor for poultry and eggs. Ng et al. (1982b) suggested a value of $2 \times 10^{-3}$ for beef based on stable-element concentration of $\mathrm{Ni}$ in meat and feed. More studies are needed to support any of these values and adequately describe the transfer process for $\mathrm{Ni}$.

\subsubsection{Selenium}

Se has been extensively studied with regard to its nutrition, absorption, and toxicity in foodproducing animals. Selenium content in the natural environment varies such that it can be toxic to animals in some areas and deficient for animals in other areas. Soluble forms of Se are very efficiently absorbed from the GI tract, but bioavailability is highly dependent upon chemical form and the presence of other interacting dietary elements and conditions. Some differences in metabolism exist between monogastric and ruminant animals.

There appears to be no homeostatic control of Se absorption in the animals studied. Selenium concentrations in animal tissues, such as muscle and milk, reflect the dietary level of Se over a wide range of concentration. The concentration of Se in poultry and eggs also varies with the Se intake. Dietary increases in Se can result in large increases in the Se content of milk and in meat. The amount of dietary selenium transferred to cow milk depended on the Se status of the animal and on the dietary source of the Se (Conrad and Moxon 1979). The transfer of Se from sodium selenite to the milk of cows on adequate Se diets was only $0.9 \%$ compared to $4.8 \%$ in the milk of cows consuming diets low in Se. More Se (19\%) appeared in the milk when brewers grain was fed with a diet low in selenium.

Little effort has been undertaken to develop Se transfer coefficients for animal food products. The transfer of soluble ${ }^{75} \mathrm{Se}$ to the milk of dairy cows, experimentally treated for 14 consecutive days, was $0.29 \pm 0.1 \%\left(2.9 \times 10^{-3} \mathrm{~d} / \mathrm{L}\right)$, calculated when secretion in the milk reached or approached a plateau of concentration (Sam et al. 1980). Transfer coefficients derived by Ng et al. (1982b) from stable element concentrations were $0.32 \mathrm{~d} / \mathrm{kg}$ for pork and $9 \mathrm{~d} / \mathrm{kg}$ for poultry and eggs.

Further studies are needed to adequately describe transfer coefficients of Se in animal products.

\subsubsection{Strontium}

Strontium absorption by the animal is closely associated with the absorption of its stable analogue $\mathrm{Ca}$. Intestinal absorption of $\mathrm{Ca}$, an essential dietary element, is very strongly homeostatically controlled. The Ca requirement of the animal varies according to age, stage of 
gestation, milk production, and species. Likewise, the behavior of $\mathrm{Sr}$ is influenced by the changing requirements of $\mathrm{Ca}$. Thus, for normal ranges of $\mathrm{Ca}$ intake, a single transfer-coefficient value of Sr may not adequately describe its behavior.

$\mathrm{Ng}$ et al. (1982b) reported transfer coefficients for ${ }^{90} \mathrm{Sr}$ from forage to cow milk from $1 \times 10^{-3}$ to $2.6 \times 10^{-3} \mathrm{~d} / \mathrm{L}$ for weapons-testing fallout, and Coughtrey (1990) estimated a similar value of $2.8 \times 10^{-3} \mathrm{~d} / \mathrm{L}$ for cow milk. However, lower factors $\left(5\right.$ to $\left.12 \times 10^{-4} \mathrm{~d} / \mathrm{L}\right)$ were reported for hay and pasture fed to cows following the Chernobyl accident (Fabbri et al. 1994; Gastberger et al. 2001).

Because of the strong relationship between $\mathrm{Sr}$ and $\mathrm{Ca}$ and the variable requirement of the animal for Ca, Howard et al. (1997) recently proposed an approach to more accurately describe the behavior of ${ }^{90} \mathrm{Sr}$ in milk. A relationship was derived between Ca dietary intake and the transfer coefficient that also considers the observed ratio (O-R) between $\mathrm{Ca}$ and $\mathrm{Sr}$ in milk and feed. This approach was validated in cows (Howard et al. 1997) and goats (Beresford et al. 1998a). The authors demonstrated an inverse relationship between $\mathrm{Sr}$ transfer coefficients for cow and goat milk and the daily $\mathrm{Ca}$ intake. This would substantially reduce earlier estimates of $\mathrm{Sr}$ transfer coefficients in the milk of cows and goats and possibly other dairy ruminants, especially if dietary $\mathrm{Ca}$ were high.

The use of transfer coefficients to describe the behavior of $\mathrm{Sr}$ is limited for other meat and poultry products, partly because of uncertainty of the role that Ca may have on Sr transfer. Coughtrey (1990) derived 100-day equilibrium transfer coefficients for $\mathrm{Sr}$ in meat as follows: beef $\left(8 \times 10^{-4} \mathrm{~d} / \mathrm{kg}\right)$, veal $\left(8 \times 10^{-3} \mathrm{~d} / \mathrm{kg}\right)$, sheep and goat $\left(4 \times 10^{-3} \mathrm{~d} / \mathrm{kg}\right)$, lamb $\left(3.3 \times 10^{-2} \mathrm{~d} / \mathrm{kg}\right)$, pork $\left(2.1 \times 10^{-2} \mathrm{~d} / \mathrm{kg}\right)$, and chicken $\left(6 \times 10^{-2} \mathrm{~d} / \mathrm{kg}\right)$. The comparable value for eggs was $1.8 \times 10^{-1} \mathrm{~d} / \mathrm{kg}$, substantially greater than milk and meat products.

Further study is needed to determine the validity of the transfer coefficient for evaluating $\mathrm{Sr}$ behavior in milk and meat products. Alternative approaches should be evaluated in models used to predict the transfer of Sr to milk and other foods.

\subsubsection{Zirconium}

Milk and meat transfer coefficients were obtained from a study by Johnson et al. (1988) in which single oral doses of ${ }^{95} \mathrm{Zr}$ oxalate were given to one dairy cow and three goats. Based on these small sample sizes, the transfer to goat milk $\left(6.0 \times 10^{-6} \mathrm{~d} / \mathrm{L}\right)$ appears to be an order of magnitude greater than to cow milk $\left(5.5 \times 10^{-7} \mathrm{~d} / \mathrm{L}\right)$. Transfer factors for beef and goat meat were $5.5 \times 10^{-6}$ and $5.5 \times 10^{-5} \mathrm{~d} / \mathrm{kg}$, respectively, almost an order of magnitude difference. Transfer coefficients for ${ }^{95} \mathrm{Zr}$ oxalate in poultry and eggs were determined after acute oral doses were administered to laying hens (Ennis et al. 1988b). Transfer coefficients for eggs are about an order of magnitude greater than that of hen's meat $\left(2 \times 10^{-4}\right.$ vs $\left.6 \times 10^{-5} \mathrm{~d} / \mathrm{kg}\right)$.

\subsubsection{Niobium}

Johnson et al. (1988) conducted a series of acute experiments using single oral doses of niobium oxalate in cows and goats. The transfer coefficient for cow milk $\left(4.1 \times 10^{-7} \mathrm{~d} / \mathrm{L}\right)$ was about an order of magnitude less than that for goat milk $\left(6.4 \times 10^{-6} \mathrm{~d} / \mathrm{L}\right)$. The corresponding value for goat 
meat $\left(6 \times 10^{-5} \mathrm{~d} / \mathrm{L}\right)$ was more than a magnitude greater than that of beef $\left(2.6 \times 10^{-7} \mathrm{~d} / \mathrm{L}\right)$. The estimated transfer value for sheep meat was $2 \times 10^{-4}$ (IAEA 1994), based on a review of the literature.

\subsubsection{Technetium}

Several studies have investigated the absorption and metabolism of Tc in animals. The absorption of Tc by the ruminant gastrointestinal tract may be considerably less than for monogastric animals. In both monogastric and ruminant animals, Tc tends to be deposited in the thyroid and kidney (Jones 1989; Gerber et al. 1998). Relatively high amounts were absorbed by quail, and about $8 \%$ of the oral dose was transferred to eggs (Thomas et al. 1984).

The transfer coefficient of Tc appears to depend on the isotope form. Johnson et al. (1988) and Ennis et al. (1988a) reported for goat milk that the transfer coefficient for ${ }^{99} \mathrm{Tc}$ was greater than that of ${ }^{95 \mathrm{~m}} \mathrm{Tc}$ and ${ }^{99 \mathrm{~m}} \mathrm{Tc}$. Furthermore, the transfer coefficient of ${ }^{95 \mathrm{~m}} \mathrm{Tc}$ was greater than that of ${ }^{99 \mathrm{~m}} \mathrm{Tc}$ for both goat and cow milk. There is no stable carrier for Tc, and the transfer is inversely proportional to the specific activity. The ${ }^{99 \mathrm{~m}} \mathrm{Tc}$ transfer to goat meat was $2.2 \times 10^{-4}$, but data for other isotopes of Tc are not available. No comparable data were found for other foods, but it is likely that Tc transfer coefficients for meat and possibly eggs may also be influenced by specific activity.

Transfer coefficients were calculated by $\mathrm{Ng}$ et al. (1982b) based on data from quail fed ${ }^{95 \mathrm{~m}} \mathrm{Tc}$ as pertechnetate, applied to the surface of alfalfa, or incorporated into the plant (Thomas et al. 1984). Estimates for meat were relatively high at 0.35 or $1 \mathrm{~d} / \mathrm{kg}$ for the two conditions, respectively.

The high uptake values in some species, unusual isotopic effects in ruminants, and the overall lack of information concerning Tc transfer to animal products all support the need for more research regarding Tc transfer in these animals.

\subsubsection{Silver}

Ag is not an extensively studied element in animal biology. The release of ${ }^{110 \mathrm{~m}} \mathrm{Ag}$ into the environment at the Chernobyl accident aroused interest in the uptake of this element in foodproducing animals.

The ${ }^{110 \mathrm{~m}} \mathrm{Ag}$ from Chernobyl was concentrated in the liver of sheep following oral and intravenous administration (Martin et al. 1989; Beresford et al. 1994). The ${ }^{110 \mathrm{~m}} \mathrm{Ag}$ was reported in the liver of sheep and cattle following the Chernobyl accident (Beresford 1989). Beresford (1989) reported liver transfer coefficients in two studies in sheep consuming Chernobylcontaminated rye grass grown in 1986 or 1987. Coefficients were greater in lambs than adults in the 1986 study ( 2.19 vs $0.64 \mathrm{~d} / \mathrm{kg}$ ), but not in the 1987 study ( $<1.55 \mathrm{vs} 1.61 \mathrm{~d} / \mathrm{kg}$ ). Subsequently, Beresford et al. (1998b) reported transfer coefficients for the muscle of sheep following a single dose of ${ }^{110 \mathrm{~m}} \mathrm{Ag}$ nitrate. Derived values extrapolated at 100 days or at equilibrium were $3.99 \times 10^{-4}$ and $4.75 \times 10^{-4} \mathrm{~d} / \mathrm{kg}$. These values are less than previous data from modeling would suggest and raise the possibility that the models such as IAEA overestimate transfer values for the meat of 
sheep. Transfer coefficients for ewe milk were less than $0.04 \mathrm{~d} / \mathrm{L}$. No data are available for the transfer of Ag to other animal food products.

There continues to be insufficient information to adequately evaluate Ag transfer in foodproducing animals, and additional data are needed.

\subsubsection{Tin}

Inorganic and most organic Sn compounds (alkyltin and aryltin compounds) are poorly absorbed from the gastrointestinal tract. Exceptions are trimethyl and triethyltin compounds that are well absorbed. The ${ }^{113} \mathrm{Sn}$ was poorly absorbed by the pig, but absorption was substantially greater in the neonate compared to the adult (Sullivan et al. 1984).

The calculated estimate of Sn transfer into milk was $1 \times 10^{-3} \mathrm{~d} / \mathrm{L}$ for cow milk based on the milk concentration of $\mathrm{Sn}$ and related forage ( $\mathrm{Ng}$ et al. 1982a). Information for meat and poultry products is not available.

Further studies of Sn are needed to provide data for developing transfer values for this radionuclide.

\subsubsection{Iodine-129}

Iodine-129 is the only long-lived isotope of I $\left(1.6 \times 10^{-7}\right.$ years $)$. Although thyroid ${ }^{129} \mathrm{I} /{ }^{127} \mathrm{I}$ ratios have been extensively reported, very little information is available on transfer coefficients for ${ }^{129} \mathrm{I}$ (Handl et al. 1990). Handl and Pfau (1989) investigated the transfer of ${ }^{129}$ I to milk from a cow fed hay labeled with ${ }^{139} \mathrm{I}$ via root uptake and concluded that the transfer coefficient for ${ }^{129} \mathrm{I}$ $\left(2.4 \times 10^{-3} \mathrm{~d} / \mathrm{kg}\right)$ was essentially the same as they had obtained in an earlier study for Chernobyl

${ }^{131}$ I fallout $\left(2.6 \times 10^{-3} \mathrm{~d} / \mathrm{kg}\right.$ ) (Handl and Pfau 1987). Transfer coefficients from contaminated cow milk to pig muscle averaged $3.8 \times 10^{-2} \mathrm{~d} / \mathrm{kg}$. Experimental and derived values for ${ }^{131} \mathrm{I}$ are readily available for most animal food products and may adequately describe ${ }^{129} \mathrm{I}$ behavior for the purposes of transfer-coefficient assessment. The same behavior and transfer-coefficient values for the milk of dairy cows were reported by Vandecasteele et al. (2000) for ${ }^{131}$ I and stable I (range 0.015 to $0.020 \mathrm{~d} / \mathrm{L}$ ). High dietary stable I reduced the transfer of ${ }^{131} \mathrm{I}$ due to competition for the two isotopic forms by milk and thyroid affinity and saturation pathways, but not by differences in absorption of the two forms. Most chemical forms of I are efficiently absorbed by the gut.

Data suggest an isotope effect for carrier-free radionuclides such as Tc. Although isotope effects are not known for radionuclides with an abundant carrier, research is needed to determine if the behavior of the long-lived ${ }^{129}$ I closely follows that of ${ }^{131}$ I with regard to transfer coefficients in animals' systems. If not, further study of ${ }^{129} \mathrm{I}$ would be warranted.

\subsubsection{Cesium}

Cesium behaves like potassium because they have similar chemical and physical properties. Cesium enters the human diet through meat and milk and is primarily in intracellular fluid. 
Much concern has arisen over the environmental contamination from worldwide fallout from nuclear testing, the Chernobyl accident, and other smaller releases to the environment.

More in known about transfer coefficients for ${ }^{137} \mathrm{Cs}$, especially in milk, than for any other radionuclide. In general, most studies put the transfer coefficient for ${ }^{137} \mathrm{Cs}$ at about $10^{-3} \mathrm{~d} / \mathrm{L}$. Ward and Johnson (1989) proposed at least three scenarios that apply to ${ }^{137} \mathrm{Cs}$ transfer coefficients to milk: soluble form, fallout from nuclear testing, and the Chernobyl accident. The proposed values are about $15 \times 10^{-3} \mathrm{~d} / \mathrm{L}$ for soluble forms 4 to $5 \times 10^{-3} \mathrm{~d} / \mathrm{L}$ for ${ }^{137} \mathrm{Cs}$ contaminated forage from worldwide fallout, and $2 \times 10^{-3} \mathrm{~d} / \mathrm{L}$ for contaminated forage from Chernobyl fallout. Numerous studies were conducted in various countries of Europe following the Chernobyl accident, and results of many were lower than found in the United States for worldwide fallout. Kirchner (1994) derived a milk-transfer coefficient of $5.4 \times 10^{-3} \mathrm{~d} / \mathrm{L}$ for the grass-cow-milk pathway from 11 selected Chernobyl fallout data sets that met basic criteria for completeness and technique.

Transfer coefficients for sheep and goat milk are at least an order of magnitude greater than for cow milk. The reason for this difference is not clear at this time.

In addition to milk, Cs is readily transferred to muscle mass, and considerable data are available on the transfer coefficients in meat. The transfer coefficient for beef is in the range of $10^{-2}$ to $10^{-3} \mathrm{~d} / \mathrm{kg}$. Coefficients for sheep and goat meat appear to be about an order of magnitude greater than beef. Transfer coefficients of ${ }^{137} \mathrm{Cs}$ for poultry and eggs are even greater than those of sheep and goats as reported by Voigt et al. (1993) for meat and eggs of laying hens fed ${ }^{137} \mathrm{Cs}-$ contaminated grass pellets or wheat. Transfer coefficients were 0.2 and $0.4 \mathrm{~d} / \mathrm{kg}$ for eggs and 1.2 to 1.6 and 2.8 to 3.0 for meat from the grass pellet and wheat diets, respectively.

An interesting relationship exists between reported ${ }^{137} \mathrm{Cs}$ transfer coefficients and species. It appears that the smaller the animal, the greater the transfer coefficient. Whether this is related to differences in body mass, metabolic rate, or amount of feed ingested is not known.

Several studies suggest that Cs taken into the plant is more available to the animal than that deposited on the plant surface. Transfer coefficients were nearly an order of magnitude greater in the milk of cows eating forage when Cs was sprayed on the pasture soil surface (Ward et al. 1989) compared to being sprayed directly on the growing plant (Van den Hoek et al. 1969). The solubility of the Cs is an important determinate for absorption and deposition in food products.

There is an extensive literature of Cs transfer to animal food products, and some of the basic principles reported may apply to other less-studied radionuclides. Resources for further study should be allotted to other radionuclides.

\subsubsection{Thorium}

There is very little information regarding the transfer of radiothorium to animal food products that are useful for establishing transfer coefficients. $\mathrm{Ng}$ et al. (1982a) suggested a value of 3 to $5 \times 10^{-6}$ for cow milk based on absorption data and milk or forage concentration data in the 
absence of animal experiments. Based on its chemistry, thorium would be expected to behave similar to $\mathrm{Pu}$, but more data are needed.

\subsubsection{Uranium}

Although considerable data are available on the $U$ content of foodstuffs, there is little data of value for deriving transfer coefficients for animal products. Transfer coefficients were calculated for poultry and eggs from $U$ concentrations in market-purchased products and from the U concentration of rock-phosphate supplements in hen's diets (Izak-Biran et al. 1989). Transfer coefficients were 0.3 and $1.2 \mathrm{~d} / \mathrm{kg}$ for poultry and eggs, respectively, and relatively high compared to values for rare-earth elements seen for other species.

\subsubsection{Neptunium}

$\mathrm{Np}$ is of interest because of its long half-life and its relative abundance in nuclear waste. Gastrointestinal absorption of $\mathrm{Np}$ was found to increase with decreasing specific activity when orally administered to rodents and baboons. This may be because all of the $\mathrm{Np}(\mathrm{V})$ is reduced to $\mathrm{Np}(\mathrm{VI})$ in the intestine at low masses, but with high quantities, complete reduction does not take place (Harrison 1991). The rat absorbed about $1 \%$ of an oral dose of ${ }^{237} \mathrm{~Np}$ nitrate (Sullivan et al. 1985 ). Only $0.01 \%$ of a single oral dose of ${ }^{237} \mathrm{~Np}$ (in a citrate solution) was secreted in the milk of lactating goats (Mullen et al. 1977). Neptunium-237 concentrations in the muscle of these goats were only 3 to $6 \times 10^{-7} \%$ of the dose per gram. This suggests limited intestinal transport of $\mathrm{Np}$ to the animal. Absorption of ${ }^{237} \mathrm{~Np}$ was increased 7-fold in iron-deficient rats (more than any other actinide studied), suggesting that the mechanism for absorption may be partly via ironabsorptive transport systems in the intestine (Sullivan and Ruemmler 1988).

Except for sheep, direct data for the calculation of ${ }^{93} \mathrm{~Np}$ transfer to animal food products were not found. McClellan et al. (1962) grouped ${ }^{233} \mathrm{U},{ }^{237} \mathrm{~Np}$, and ${ }^{239} \mathrm{Pu}$ together because of their similar milk:plasma ratios. $\mathrm{Ng}$ (1982) approximated values for cow milk based on intravenous administration in these sheep as compared to the behavior of other radionuclides in the two species. A coefficient of $1 \times 10^{-4} \mathrm{~d} / \mathrm{L}$ for sheep milk was calculated by Coughtrey (1990) based on single dosing studies.

\subsubsection{Plutonium}

Although Pu may exist in four different oxidation states, most studies have been conducted using $\mathrm{Pu}(\mathrm{IV})$. Plutonium is thought to be quadrivalent during absorption and in the plasma, but similar absorption values have been reported for $\mathrm{Pu}(\mathrm{IV})$ and $\mathrm{Pu}(\mathrm{VI})$ in monogastric animals (Harrison 1991). In general, $\mathrm{Pu}$ absorption is greater when bound to organic ligands such as citrate and phytate compared to organic forms such as nitrate or the poorly absorbed oxides. It has been suggested by several studies that $\mathrm{Pu}$ and iron may compete for the same intestinal transport system (Sullivan and Ruemmler 1988).

Primary data for the estimation of transfer coefficients of Pu are rare, and few studies have been conducted from which feed to milk or meat transfer coefficients can be calculated. For milk, three studies (Stanley et al. 1975; Sansom 1964; Sumerling et al. 1984) with experimental data 
are available, although none provide sufficient data to calculate milk transfer coefficients directly without making some assumptions. Most derived or model predictions use these data.

Calculated and derived transfer coefficients for beef are based on the tissue-concentration data of Stanley et al. (1975). Again, transfer coefficients were not the objective of the study. No experimental data are available from calves.

Sheep and lamb transfer coefficients have been estimated from the tissue-concentration data from Howard and Lindsey, assuming a forage intake of $6 \mathrm{~kg}$ /day. Only data modeling provides estimates of pork transfer coefficients of $\mathrm{Pu}$.

A relatively large proportion of ingested $\mathrm{Pu}$ citrate $(0.0155 \%$ of the dose) was transferred to the eggs of hens, but lesser amounts (about an order of magnitude) from plutonium dioxide (Mullen 1974; Mullen et al. 1976). Predicted transfer coefficients are quite variable (Ng et al. 1982b; Coughtrey 1990).

\subsubsection{Americium}

At the $\mathrm{pH}$ of the intestine, Am is not as readily hydrolyzed as $\mathrm{Pu}$. Am binds to ferritin and transferrin, the iron-transport proteins, but not as firmly as does Pu (Stover et al. 1968; Bruenger et al. 1969; Cooper and Gowing 1981; Sullivan et al. 1984). Relative absorption is strongly dependent on the chemical form.

The reported transfer factors for Am in food-producing animals are sparse, and data that are available do not allow the calculation of transfer coefficients per se without making some assumption about intake or concentration. Transfer coefficients for milk from dairy cows in a 2-year field study near Sellafield were calculated by Sumerling et al. (1984) at $<1 \times 10^{-4}$ for Am. Data of a single oral dose study of ${ }^{241} \mathrm{Am}$ in cow milk, collected over 7 days (Sutton and Mullen 1977), were used by $\mathrm{Ng}(1982)$ to derive a considerably lower transfer coefficient of $4 \times 10^{-7}$.

Americium transfer coefficients for beef are derived from data of the studies of Sumerling et al. (1984) and Sutton and Mullen (1977) listed above. Values calculated by Sumerling et al. (1984) were about $3.6 \times 10^{-4}$ and $3.1 \times 10^{-3} \mathrm{~d} / \mathrm{kg}$ for muscle and liver, respectively. $\mathrm{Ng}(1982)$ set a value of $3.6 \times 10^{-4}$ for muscle based on concentration data of Sutton et al. (1977). Experimental data were not found for sheep or goats, but Coughtrey's 110-day equilibrium value is $4 \times 10^{-5}$ and $1 \times 10^{-3}$ for adult sheep and lambs, respectively. No other experimental data were found for young animals.

Eisele et al. (1987) dosed 11-week-old swine with a single oral dose of ${ }^{241}$ Am citrate, and reported a fractional gastrointestinal absorption of $1.1 \times 10^{-3}$ at 8 hours after radionuclide administration and tissue distribution at 30 hours of 50,20, and 30\% for bone, liver, and other soft tissues, respectively. Experimental data are limited for Am transfer coefficients in pork, but Coughtrey's (1990) model gives a value of $1.7 \times 10^{-4} \mathrm{~d} / \mathrm{kg}$.

Limited experimental data are available on the transfer of Am to poultry and eggs through ingestion (Mullen 1974; Mullen et al. 1976). These data have been applied to modeling procedures (Ng 1982; Coughtrey 1990). 


\subsubsection{Curium}

Curium binds to the iron-transport proteins, but not quite as firmly as the other actinides, and absorption probably occurs at least partly via this transport system. The absorption of $\mathrm{Cm}$, as well as the other actinides, may vary several orders of magnitude, depending the chemical form (Harrison 1991). Only $2 \%$ of an intravenous dose of ${ }^{243} \mathrm{Cm}$ chloride (citrate buffered) was secreted in the milk of goats and a cow during a 6-day study; the muscle content was 0.27 and $0.009 \% / \mathrm{kg}$ (4.9 and 3\% total) for goats and the cow, respectively (Patzer et al. 1977).

Curium-244 transfer coefficients were not available for food-producing animals. Based on plasma-to-milk ratios in sheep from intravenous injections of ${ }^{244} \mathrm{Cm}$ (in the nitrate form) reported by McClellan et al. (1962), the transfer of $\mathrm{Cm}$ to sheep milk would be expected to approximate that of Am. Ng's (1982) derived transfer coefficient of $2 \times 10^{-5}$ for $\mathrm{Cm}$ was based on data for related rare-earth elements. Transfer-coefficient values for $\mathrm{Cm}$ may approximate those of the other actinides, especially Am.

\subsection{Overall Needs}

1. Basic data are needed for understanding the fundamental factors that influence feed-toproduct transfer of radionuclides for most radionuclides.

- The transfer of ${ }^{137} \mathrm{Cs}$ to food products is well studied because of worldwide contamination. A number of factors have been identified that influence the transfer of ${ }^{137} \mathrm{Cs}$ from feed to animal products, including diet, age of the animal in some cases, solubility of the Cs source, soil type of the harvested feed, and chemical form.

- Data that describe the effects of these factors on transfer-coefficient values are rare for most other radionuclides of interest. Limited data are available for $\mathrm{Pu}, \mathrm{Am}$, and ${ }^{99} \mathrm{Tc}$, but data for ${ }^{121} \mathrm{Sn},{ }^{79} \mathrm{Se},{ }^{232} \mathrm{Th},{ }^{242} \mathrm{Cm}{ }^{110} \mathrm{Be},{ }^{63 / 59} \mathrm{Ni}$, and ${ }^{108 \mathrm{~m}} \mathrm{Ag}$ are especially rare.

- Reports show that the transfer coefficient for ${ }^{137} \mathrm{Cs}$ and some other radionuclides may be inversely related to body size of the animal species (i.e., beef $<$ sheep $<$ poultry). Understanding the mechanism of this phenomenon could be useful for predictive use.

2. Validate the appropriateness of the transfer-coefficient concept for radionuclides of interest not previously validated by experimental data.

- The appropriateness of the transfer coefficient is poorly validated for several of the radionuclides evaluated. The validation for ${ }^{137} \mathrm{Cs}$ in milk and meat is based on solid data. Information is lacking for ${ }^{121} \mathrm{Sn},{ }^{79} \mathrm{Se},{ }^{232} \mathrm{Th},{ }^{242} \mathrm{Cm}{ }^{110} \mathrm{Be},{ }^{63 / 59} \mathrm{Ni}$ and ${ }^{108 \mathrm{~m}} \mathrm{Ag}$.

3. Alternative approaches are needed for estimating transfer coefficients for homeostatically controlled radionuclides or those that may not be appropriately evaluated using the current transfer-coefficient concept. 
- It is clear that those radionuclides, such as ${ }^{90} \mathrm{Sr}$ and possibly ${ }^{131} \mathrm{I}$ in some cases, that are homeostatically controlled by mechanisms designed to maintain optimum plasma or tissue levels of a particular radionuclide or its analog have highly variable transfer coefficients.

- Recently, an alternative approach was proposed for ${ }^{90} \mathrm{Sr}$ cow/sheep-to-milk transfer. Further study of this approach has merit for meat and poultry scenarios and possibly for other radionuclides.

4. Evaluate existing data of selected stable elements that may be useful in deriving transfer coefficients and improve the understanding of transfer values for a wider range of food products.

- For example, the absorption and distribution of Se, a readily bioavailable nutrient, is not homeostatically controlled. Few attempts have been made to derive transfer coefficients for Se, yet a large volume of stable elemental data is available in the existing literature for most animal species. These data should be evaluated for their usefulness in deriving transfer coefficients.

5. Laboratory-animal experiments are needed to establish transfer coefficients for radionuclides for which the transfer behavior from feed-to-product is not well established.

- Major gaps exist in the available data to establish transfer coefficients of most food products for the following radionuclides: ${ }^{99} \mathrm{Tc},{ }^{121} \mathrm{Sn},{ }^{79} \mathrm{Se},{ }^{232} \mathrm{Th},{ }^{242} \mathrm{Cm}{ }^{110} \mathrm{Be},{ }^{63 / 59} \mathrm{Ni}$, and ${ }^{108 \mathrm{~m}} \mathrm{Ag}$.

- More animal studies are needed on the transfer of Tc to food products because of reported high uptake values, toxicity, and isotopic effects in some species.

- $\quad$ Provide data to complement and fill in gaps for ${ }^{75}$ Se after completion of stable data analysis.

- The scope of the outlined needs may be cost prohibitive. Classify radionuclides according to risk, bioavailability, and chemical similarity and prioritize research agenda.

- $\quad$ Set up collaborative efforts with other laboratories, especially FSU facilities, to evaluate recent data (unpublished or published in the foreign literature) from Chernobyl. 
Table 4.1. Radionuclide Transfer Coefficients for Cow Milk

\begin{tabular}{|c|c|c|c|c|c|c|}
\hline Atomic \# & Isotope & Reference & Source/form & Fm (d/L) & $\begin{array}{r}\text { Comments } \\
\end{array}$ & Code \\
\hline 28 & $\mathrm{Ni}$ & IAEA 1994 & literature review & $1.6 \times 10^{-2}$ & Cramp et al. 1990 & $\mathrm{R}$ \\
\hline 28 & $\mathrm{Ni}$ & $\mathrm{Ng} 1982$ & literature review & $1 \times 10^{-3}$ & Based on milk conc. and related forage & $\mathrm{R}$ \\
\hline 34 & ${ }^{75} \mathrm{Se}$ & Sam et al. 1980 & ionic & $2.9 \times 10^{-3}$ & 14-d study; approach conc. plateau & E \\
\hline 38 & ${ }^{90} \mathrm{Sr}$ & IAEA 1994 & model prediction for 100 day & $0.28 \times 10^{-2}\left(0.1^{-0.3} \times 10^{-2}\right)$ & Coughtrey 1990 & $\mathrm{M}$ \\
\hline 38 & ${ }^{90} \mathrm{Sr}$ & Prohl et al. 1989 & 50-yr integra activity calc & $2 \times 10^{-3}$ & & $\mathrm{M}$ \\
\hline 38 & ${ }^{90} \mathrm{Sr}$ & Fabbri et al. 1994 & hay & $8 \pm 2 \times 10^{-4}$ & & $\mathrm{~F}$ \\
\hline 38 & ${ }^{90} \mathrm{Sr}$ & Woodman and Nisbet 1999 & drinking water & $2 \times 10^{-3}$ & model prediction & $\mathrm{M}$ \\
\hline 38 & ${ }^{90} \mathrm{Sr}$ & Beresford et al. 2000 & pasture -Chernobyl & $0.43 \times 10^{-3}$ & $3.5 \mathrm{~km}$ from nuclear plant & $\mathrm{F}$ \\
\hline 38 & ${ }^{90} \mathrm{Sr}$ & Gastberger et al. 2001 & pasture & $5-12 \times 10^{-4}$ & intake est. from weight and milk yield & $\mathrm{F}$ \\
\hline 40 & ${ }^{95} \mathrm{Zr}$ & Johnson et al. 1988; IAEA 1994 & $\mathrm{Zr}(\mathrm{VI})$ Oxalate & $5.5 \times 10^{-7}$ & single administration & $\mathrm{E}$ \\
\hline 41 & ${ }^{95} \mathrm{Nb}$ & Johnson et al. 1988; IAEA 1994 & $\mathrm{Nb}(\mathrm{III})$ Oxalate & $4.1 \times 10^{-7}$ & single administration & $\mathrm{E}$ \\
\hline 42 & ${ }^{99} \mathrm{Mo}$ & Johnson et al. 1988 & $\mathrm{MoO}_{3}$ & $1.7 \pm .2 \times 10^{-3}$ & single administration & $\mathrm{E}$ \\
\hline 43 & ${ }^{95 \mathrm{~m}} \mathrm{Tc}$ & Voigt et al. 1988 & ionic & $1.7 \times 10^{-4}-2 \times 10^{-6}$ & & $\mathrm{E}$ \\
\hline 43 & ${ }^{95 \mathrm{~m}} \mathrm{Tc}$ & Johnson et al. 1988 & $\mathrm{NaTcO}_{4}$ & $1.4 \times 10^{-4}$ & single administration & $\mathrm{E}$ \\
\hline 43 & ${ }^{95 \mathrm{~m}} \mathrm{Tc}$ & Johnson et al. 1988 & $\mathrm{NaTcO}_{4}$ & $2.3 \times 10^{-5}$ & single administration & $\mathrm{E}$ \\
\hline 47 & ${ }^{110} \mathrm{Ag}$ & IAEA 1994 & literature review & $5.0 \times 10^{-5}$ & CEC 1987 & $\mathrm{M}$ \\
\hline 50 & ${ }^{123 / 125} \mathrm{Sn}$ & $\mathrm{Ng}$ et al. $1982 \mathrm{a}$ & literature review & $1 \times 10^{-3}$ & based on milk conc. and related forage & $\mathrm{R}$ \\
\hline 53 & ${ }^{131} \mathrm{I}$ & Handl and Pfau 1987 & Chernobyl fallout & $2.6 \times 10^{-3}$ & & $\mathrm{~F}$ \\
\hline 53 & ${ }^{129} \mathrm{I}$ & Handl and Pfau 1989 & hay; root uptake & $2.4 \times 10^{-3}$ & & $\mathrm{E}$ \\
\hline 53 & ${ }^{131} \mathrm{I}$ & IAEA 1994 & literature review & $1 \times 10^{-2}\left(0.1-3.5 \times 10^{-2}\right)$ & $\begin{array}{l}\text { Hoffman 1978, Handl and Pfau 1989, } \\
\text { Hoffman et al. } 1988\end{array}$ & M \\
\hline 53 & ${ }^{131} \mathrm{I}$ & Lengemann and Comar 1964 & ionic & $1.1 \times 10^{-2}$ & & $\mathrm{E}$ \\
\hline 53 & ${ }^{131} \mathrm{I}$ & Lengemannand Comar 1964 & ionic & $0.42 \times 10^{-2}$ & & E \\
\hline 53 & ${ }^{131} \mathrm{I}$ & Sasser 1965 p. 64; Sasser and Hawley 1966 & grass (pasture study) & $1.5 \times 10^{-2}$ & controlled release of ${ }^{131} \mathrm{I}$ & $\mathrm{F}$ \\
\hline 53 & ${ }^{131} \mathrm{I}$ & Hoffman 1978 & literature review & $1 \times 10^{-2}$ & data analysis & $\mathrm{R}$ \\
\hline 53 & ${ }^{131} \mathrm{I}$ & $\mathrm{Ng}$ et al. 1982a & literature review & $9.9 \times 10^{-3}$ & summary of fallout studies & $\mathrm{R}$ \\
\hline 53 & ${ }^{131} \mathrm{I}$ & Bertilsson et al. 1988 & green -cut(high stubble & $1.8 \times 10^{-2}$ & & E \\
\hline 53 & ${ }^{131} \mathrm{I}$ & Bertilsson et al. 1988 & green -cut(low stubble & $2 \times 10^{-2}$ & & E \\
\hline 53 & ${ }^{131} \mathrm{I}$ & Voigt et al. 1988 & iodide & $9 \times 10^{-3}$ & three oral doses & E \\
\hline 53 & ${ }^{131} \mathrm{I}$ & Voigt et al. $1989 b$ & fodder Chernobyl & $7 \times 10^{-3}$ & & $\mathrm{~F}$ \\
\hline 55 & ${ }^{131} \mathrm{I}$ & Kirchner 1989 & feeding study & $4 \pm 1 \times 10^{-3}$ & cited in Kirchner 1994 & $\mathrm{R}$ \\
\hline 53 & ${ }^{131} \mathrm{I}$ & Kirchner 1994 & Chernobyl review & $3.4 \pm 0.4 \times 10^{-3}$ & summary of selected Chernobyl studies & $\mathrm{M}$ \\
\hline 53 & ${ }^{131} \mathrm{I}$ & Vandecasteele et al. 2000 & ionic_-Low stable I & $2 \times 10^{-2}$ & single administration & $\mathrm{E}$ \\
\hline
\end{tabular}


Table 4.1 (cont'd)

\begin{tabular}{|c|c|c|c|c|c|c|}
\hline Atomic \# & Isotope & Reference & $\begin{array}{l}\text { Source/form } \\
\end{array}$ & Fm (d/L) & $\begin{array}{r}\text { Comments } \\
\end{array}$ & Code \\
\hline 53 & ${ }^{131} \mathrm{I}$ & Vandecasteele et al. 2000 & ionic_-High stable I & $1.8 \times 10^{-2}$ & single administration & $\mathrm{E}$ \\
\hline 55 & ${ }^{137} \mathrm{Cs}$ & Lengemann and Wentworth 1978 & $\mathrm{CsCl}_{2}$ (steady state) & $4.7 \times 10^{-2}$ & & $\mathrm{E}$ \\
\hline 55 & ${ }^{137} \mathrm{Cs}$ & Kahn et al. 1965 & dry feed & $7.2 \times 10^{-3}$ & world wide fallout & $\mathrm{E}$ \\
\hline 55 & ${ }^{137} \mathrm{Cs}$ & Porter et al. 1966 & hay and grain & $12.1 \times 10^{-3}$ & world wide fallout & $\mathrm{E}$ \\
\hline 55 & ${ }^{137} \mathrm{Cs}$ & Porter et al. 1966 & $60 \%$ Pangola grass & $5.8 \times 10^{-3}$ & world wide fallout & $\mathrm{E}$ \\
\hline 55 & ${ }^{137} \mathrm{Cs}$ & Ward et al. 1967 & pasture & $3.5 \times 10^{-3}$ & world wide fallout & $\mathrm{F}$ \\
\hline 55 & ${ }^{137} \mathrm{Cs}$ & Ward et al. 1967 & dry feed & $4.1 \times 10^{-3}$ & world wide fallout & $\mathrm{E}$ \\
\hline 55 & ${ }^{137} \mathrm{Cs}$ & Johnson et al. 1968 & grain & $12.1 \times 10^{-3}$ & world wide fallout & $\mathrm{E}$ \\
\hline 55 & ${ }^{137} \mathrm{Cs}$ & Johnson et al. 1968 & hay & $4.8 \times 10^{-3}$ & world wide fallout & $\mathrm{E}$ \\
\hline 55 & ${ }^{137} \mathrm{Cs}$ & Hawthorne et al. 1976 & alfalfa hay & $4.5 \times 10^{-3}$ & world wide fallout & $\mathrm{F}$ \\
\hline 55 & ${ }^{137} \mathrm{Cs}$ & Bradley and Wilkins 1989 & pasture 1986-two farms & $9 \& 2-3 \times 10^{-3}$ & Chernobyl fallout/UK & $\mathrm{F}$ \\
\hline 55 & ${ }^{137} \mathrm{Cs}$ & Bradley and Wilkins 1989 & silage 1987-two farms & $2 \& 4 \times 10^{-3}$ & Chernobyl fallout/UK & $\mathrm{F}$ \\
\hline 55 & ${ }^{137} \mathrm{Cs}$ & Bertilsson et al. 1988 & green—cut(high stubble) & $6.7 \pm 1.2 \times 10^{-3}$ & Chernobyl fallout/Sweden & $\mathrm{E}$ \\
\hline 55 & ${ }^{137} \mathrm{Cs}$ & Bertilsson et al. 1988 & green-cut(low stubble) & $1.9 \pm 1.2 \times 10^{-3}$ & Chernobyl fallout/Sweden & $\mathrm{E}$ \\
\hline 55 & ${ }^{137} \mathrm{Cs}$ & Kirchner 1989 & feeding study & $7.5 \pm 1.9 \times 10^{-3}$ & cited in Kirchner 1994 & $\mathrm{R}$ \\
\hline 55 & ${ }^{137} \mathrm{Cs}$ & Pearce et al. 1989 & silage & $2-3 \times 10^{-3}\left(2-3 \times 10^{-3}\right)$ & Chernobyl fallout/UK & $\mathrm{F}$ \\
\hline 55 & ${ }^{137} \mathrm{Cs}$ & Pearce et al. 1989 & Chernobyl silage-first cut 1986 & $2.3-2.97 \times 10^{-3}$ & Chernobyl fallout/UK-5wk studies & $\mathrm{F}$ \\
\hline 55 & ${ }^{137} \mathrm{Cs}$ & Prohl et al. 1989 & 50-yr integra activity calc & $3 \times 10^{-3}$ & model prediction & $\mathrm{M}$ \\
\hline 55 & ${ }^{137} \mathrm{Cs}$ & Voors and Van Weers 1989 & silage/intake from prior data & $2.6 \times 10^{-3}\left(2.1-3.0 \times 10^{-3}\right)$ & Chernobyl fallout/The Netherlands & $\mathrm{F}$ \\
\hline 55 & ${ }^{134} \mathrm{Cs}$ & Voors and Van Weers 1989 & silage/intake from prior data & $2.7 \times 10^{-3}\left(2.1-2.9 \times 10^{-3}\right)$ & Chernobyl fallout/The Netherlands & $\mathrm{F}$ \\
\hline 55 & ${ }^{137} \mathrm{Cs}$ & Voigt et al. 1988 & ionic & $2.2 \times 10^{-3}$ & & $\mathrm{E}$ \\
\hline
\end{tabular}


Table 4.1 (cont'd)

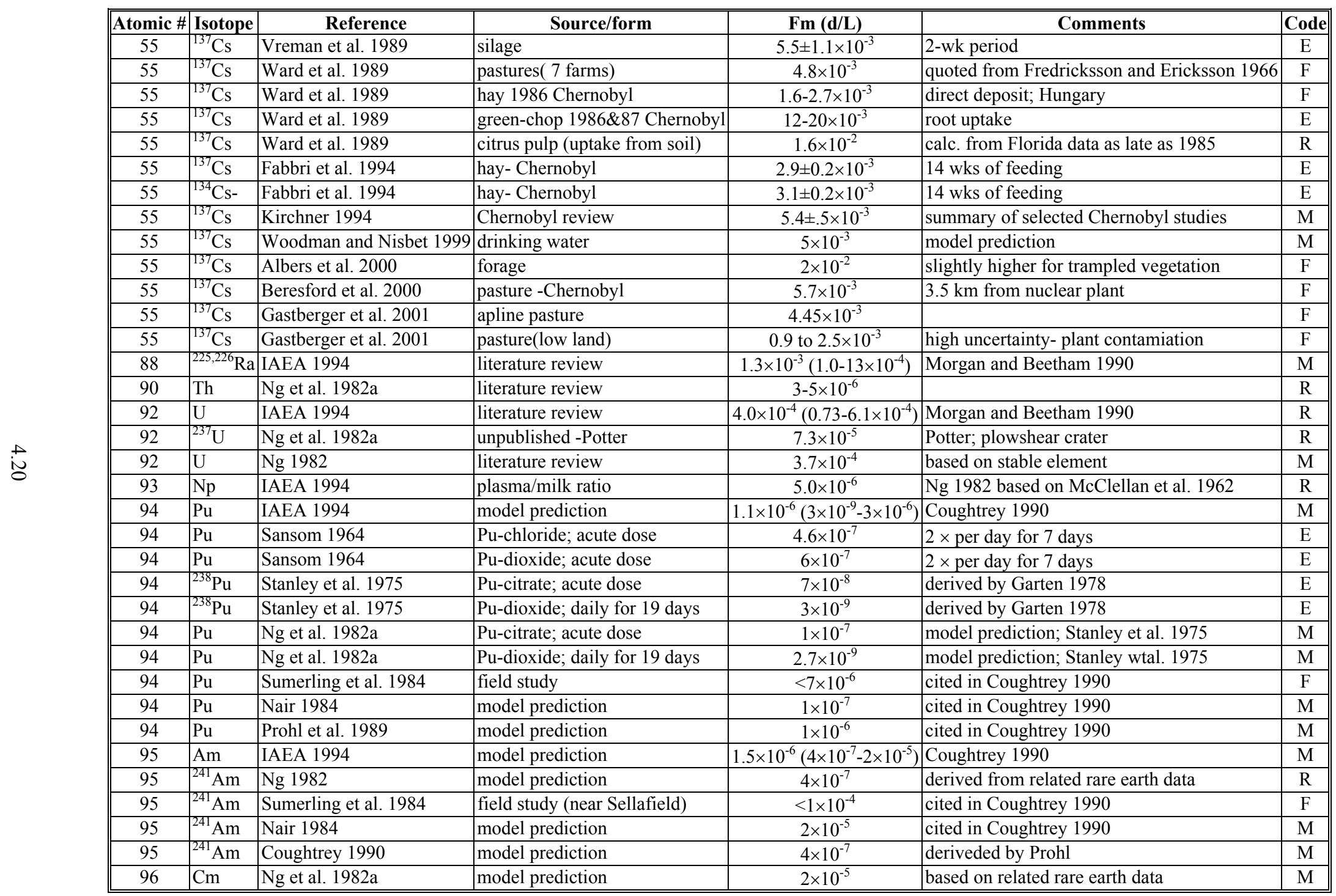


Table 4.2. Radionuclide Transfer Coefficients for Sheep Milk

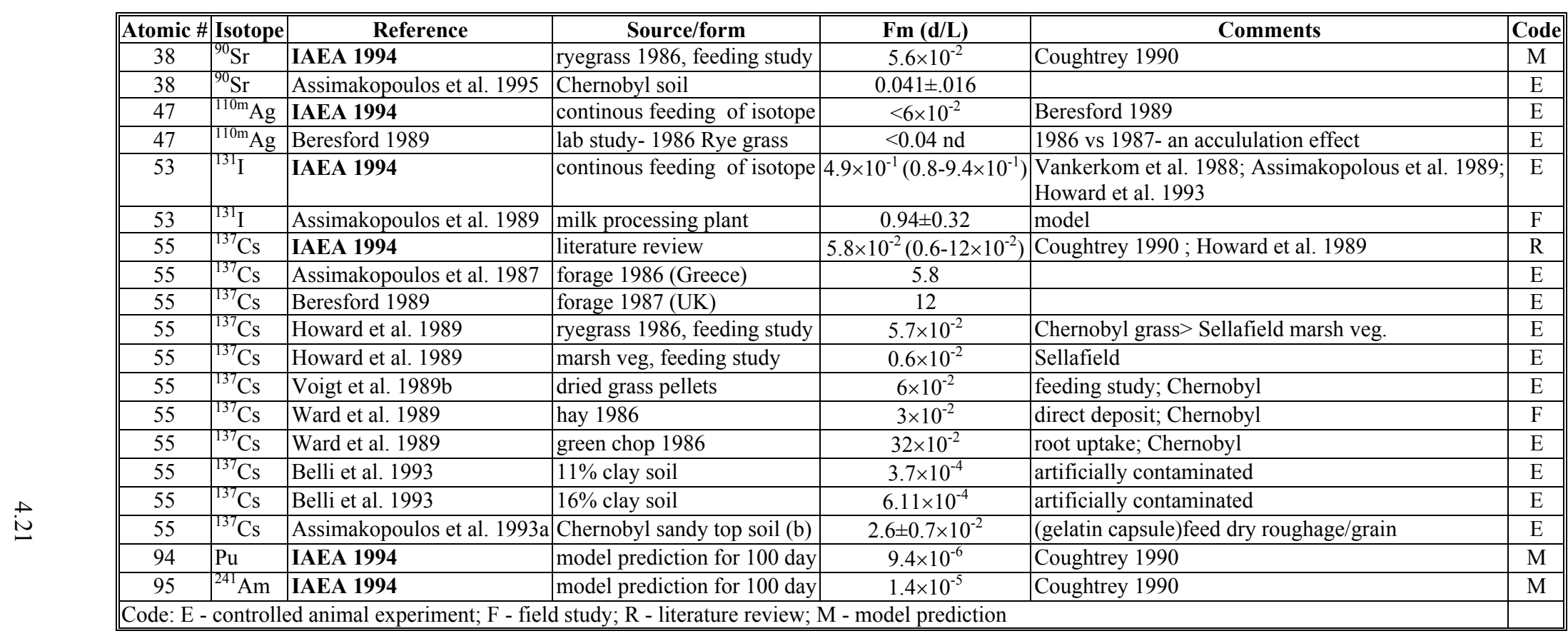


Table 4.3. Radionuclide Transfer Coefficients for Goat Milk

\begin{tabular}{|c|c|c|c|c|c|c|}
\hline Atomic \# & Isotope & Reference & Source/form & Fm (d/L) & Comments & Code \\
\hline 38 & ${ }^{90} \mathrm{Sr}$ & IAEA & model prediction for 100 day & $2.8 \times 10^{-2}\left(0.6-3.9 \times 10^{-2}\right)$ & Coughtrey 1990, Johnson and Ward 1989 & $\mathrm{M}$ \\
\hline 40 & ${ }^{95} \mathrm{Zr}$ & IAEA & $\mathrm{Zr}(\mathrm{VI}) \mathrm{Oxalate}$ & $5.5 \pm 1.1 \times 10^{-6}$ & single administration & $\mathrm{E}$ \\
\hline 41 & ${ }^{95} \mathrm{Nb}$ & Johnson et al. 1988 & $\mathrm{Nb}(\mathrm{III})$ Oxalate & $6.4 \pm 1.4 \times 10^{-6}$ & single administration & $\mathrm{E}$ \\
\hline 42 & ${ }^{99}$ Mo & Johnson et al. 1988 & $\mathrm{MoO}_{3}$ & $9.0 \times 10^{-3}$ & single administration & $\mathrm{E}$ \\
\hline 43 & ${ }^{95 \mathrm{~m}} \mathrm{Tc}$ & Johnson et al. 1988 & $\mathrm{NaTcO}_{4}$ & $8.5 \times 10^{-4}$ & single administration & $\mathrm{E}$ \\
\hline 47 & ${ }^{95 \mathrm{~m}} \mathrm{Tc}$ & Ennis et al. 1989; Johnson et al. 1988 & $\mathrm{NaTcO}_{4}$ & $1.5 \times 10^{-4}$ & $\mathrm{TcO}_{4}{ }_{4}^{-}$is reduced in rumen & $\mathrm{E}$ \\
\hline 47 & ${ }^{95} \mathrm{Tc}$ & Ennis et al. 1989; Johnson et al. 1988 & $\mathrm{NaTcO}_{4}$ & $1.1 \times 10^{-2}$ & single administration & $\mathrm{E}$ \\
\hline 53 & ${ }^{131} \mathrm{I}$ & Ennis et al. 1989 & literature review & $4.3 \times 10^{-1}\left(6 \times 10^{-2}-6.5 \times 10^{-1}\right)$ & Hoffman 1978, others & $\mathrm{R}$ \\
\hline 53 & ${ }^{131} \mathrm{I}$ & IAEA 1994 & twice daily dosing & $0.06-0.17$ & & $\mathrm{R}$ \\
\hline 53 & ${ }^{131} \mathrm{I}$ & Binnerts et al. 1962 & daily oral administration & $0.37-0.5$ & & $\mathrm{R}$ \\
\hline 53 & ${ }^{131} \mathrm{I}$ & Lengemann 1970 & data analysis & $5 \times 10^{-1}$ & & $\mathrm{M}$ \\
\hline 55 & ${ }^{137} \mathrm{Cs}$ & Hoffman 1978 & model prediction for 100 day & $1 \times 10^{-1}$ & $\begin{array}{l}\text { Coughtrey 1990; Johnson and Ward 1989; } \\
\text { Hansen and Hove } 1991\end{array}$ & $\mathrm{M}$ \\
\hline 55 & ${ }^{137} \mathrm{Cs}$ & IAEA & hay 1986 & $4.2 \pm 0.7 \times 10^{-2}$ & feeding study & $\mathrm{E}$ \\
\hline 55 & ${ }^{137} \mathrm{Cs}$ & Hansen and Hove 1991 & hay 1987 & $9.1 \pm 1.8 \times 10^{-2}$ & & $\mathrm{E}$ \\
\hline 55 & ${ }^{137} \mathrm{Cs}$ & Hansen and Hove 1991 & hay 1988 & $12.4 \pm 2.3 \times 10^{-2}$ & & $\mathrm{E}$ \\
\hline 55 & ${ }^{137} \mathrm{Cs}$ & Hansen and Hove 1991 & hay 1989 & $11.5 \pm 2.3 \times 10^{-2}$ & & $\mathrm{E}$ \\
\hline 55 & ${ }^{137} \mathrm{Cs}$ & Hansen and Hove 1991 & willow bark & $7.4 \pm 1.1 \times 10^{-2}$ & & $\mathrm{E}$ \\
\hline 55 & ${ }^{137} \mathrm{Cs}$ & Hansen and Hove 1991 & organic soil & $0.9 \pm 0.3 \times 10^{-2}$ & & $\mathrm{E}$ \\
\hline 55 & ${ }^{134} \mathrm{Cs}$ & Hansen and Hove 1991 & $\mathrm{CsCl}_{2}$ & $11.9 \pm 2.1 \times 10^{-2}$ & & $\mathrm{E}$ \\
\hline 60 & ${ }^{237} \mathrm{~Np}$ & Hansen and Hove 1991 & single administration & $1.0 \times 10^{-4}$ & Coughtrey et al. 1984 & $\mathrm{E}$ \\
\hline 94 & ${ }^{239} \mathrm{Pu}$ & IAEA 1994 & model prediction for 100 day & $9.4 \times 10^{-6}$ & Coughtrey 1990 & $\mathrm{M}$ \\
\hline 95 & ${ }^{241} \mathrm{Am}$ & IAEA 1994 & model prediction for 100 day & $1.4 \times 10^{-5}$ & Coughtrey 1990 & $\mathrm{M}$ \\
\hline \multicolumn{6}{|c|}{ Code: E - controlled animal experiment; F - field study; R - literature review; M - model prediction } & IAEA 1994 \\
\hline
\end{tabular}


Table 4.4. Radionuclide Transfer Coefficients for Beef

\begin{tabular}{|c|c|c|c|c|c|c|c|}
\hline Atomic \# & Isotope & Reference & Source/form & \begin{tabular}{|l|} 
Tissue \\
\end{tabular} & Ff (d/kg) & Comments & Code \\
\hline 28 & ${ }^{59 / 60} \mathrm{Ni}$ & IAEA 1994 & literature review & beef & $5 \times 10^{-3}$ & Cramp et al. 1990 & $\mathrm{R}$ \\
\hline 28 & $\mathrm{Ni}$ & $\mathrm{Ng}$ et al.1982b & stable element concentration & beef & $2.8 \times 10^{-3}$ & & $\mathrm{M}$ \\
\hline 38 & ${ }^{90} \mathrm{Sr}$ & IAEA 1994 & equilibrium & beef & $8 \times 10^{-3}$ & Coughtrey 1990 & $\mathrm{M}$ \\
\hline 38 & ${ }^{90} \mathrm{Sr}$ & IAEA 1994 & equilibrium & veal & $1 \times 10^{-1}$ & Coughtrey 1990 & M \\
\hline 38 & ${ }^{90} \mathrm{Sr}$ & $\mathrm{Ng} 1982$ & model prediction & beef & $3 \times 10^{-4}$ & & $\mathrm{M}$ \\
\hline 38 & ${ }^{90} \mathrm{Sr}$ & Prohl et al. 1989 & 50-yr integra activity calc & beef & $3 \times 10^{-4}$ & & $\mathrm{M}$ \\
\hline 38 & ${ }^{90} \mathrm{Sr}$ & Coughtrey 1990 & model prediction for 100 day & veal & $8 \times 10^{-4}$ & & $\mathrm{M}$ \\
\hline 38 & ${ }^{90} \mathrm{Sr}$ & Woodman and Nisbet 1999 & drinking water & beef & $3 \times 10^{-4}$ & model prediction & $\mathrm{M}$ \\
\hline 40 & ${ }^{95} \mathrm{Zr}$ & \begin{tabular}{|l|} 
Johnson et al. 1988 \\
\end{tabular} & $\mathrm{Zr}(\mathrm{VI})$ Oxalate & beef & $1.2 \times 10^{-6}$ & single dose & $\mathrm{E}$ \\
\hline 41 & ${ }^{95} \mathrm{Nb}$ & Johnson et al. 1988 & $\mathrm{Nb}$ (III)Oxalate & beef & $2.6 \times 10^{-7}$ & single dose & $\mathrm{E}$ \\
\hline 42 & ${ }^{99} \mathrm{Mo}$ & Johnson et al. 1988 & $\mathrm{MoO}_{3}$ & beef & $1 \times 10^{-3}$ & single dose & $\mathrm{E}$ \\
\hline 43 & ${ }^{95 \mathrm{~m}} \mathrm{Tc}$ & IAEA 1994 & literature review & beef & $1 \times 10^{-4}$ & Bishop et al. 1989 & $\mathrm{R}$ \\
\hline 43 & & IAEA 1994 & literature review & beef & $1 \times 10^{-6}$ & Bishop et al.1989 & $\mathrm{R}$ \\
\hline 43 & ${ }^{99 \mathrm{~m}} \mathrm{Tc}$ & Johnson et al. 1988 & $\mathrm{NaTcO}_{4}$ & beef & $7.3 \times 10^{-7}$ & single dose & $\mathrm{E}$ \\
\hline 47 & ${ }^{110} \mathrm{Ag}$ & IAEA 1994 & literature review & beef & $3 \times 10^{-3}$ & CEC 1987 & $\mathrm{R}$ \\
\hline 53 & ${ }^{129} \mathrm{I}$ & Handl and Pfau 1989 & hay; root uptake & muscle & $3.8 \times 10^{-2}$ & & $\mathrm{E}$ \\
\hline 53 & $129 / 131 \mathrm{I}$ & Handl and Pfau 1989 & hay; root uptake & liver & $7.3 \times 10^{-3}$ & & $\mathrm{E}$ \\
\hline 53 & & IAEA 1994 & continuous feeding study & beef & $4 \times 10^{-2}$ & Handl and Pfau 1989; Bishop et al. 1989 & $\mathrm{E}$ \\
\hline 53 & ${ }^{131} I$ & Ng 1982 & model prediction & beef & $7.2 \times 10^{-3}$ & & $\mathrm{M}$ \\
\hline 55 & ${ }^{137} \mathrm{Cs}$ & IAEA 1994 & model prediction to equilibrium & beef & $5 \times 10^{-2}$ & Coughtrey 1990 & $\mathrm{M}$ \\
\hline 55 & ${ }^{137} \mathrm{Cs}$ & IAEA 1994 & model prediction to equilibrium & veal & $2 \times 10^{-1}$ & Coughtrey 1990 & $\mathrm{M}$ \\
\hline 55 & ${ }^{137} \mathrm{Cs}$ & Johnson et al. 1969 & high grain & beef & $5 \times 10^{-2}$ & & $\mathrm{E}$ \\
\hline 55 & ${ }^{137} \mathrm{Cs}$ & Johnson et al. 1969 & high hay & beef & $1.5 \times 10^{-2}$ & & $\mathrm{E}$ \\
\hline 55 & ${ }^{137} \mathrm{Cs}$ & $\mathrm{Ng} 1982$ & model prediction & beef & $2 \times 10^{-2}$ & & $\mathrm{M}$ \\
\hline 55 & ${ }^{137} \mathrm{Cs}$ & Voigt et al. 1988 & ionic & muscle & $6 \times 10^{-3}$ & & $\mathrm{E}$ \\
\hline 55 & ${ }^{137} \mathrm{Cs}$ & Voigt et al. 1988 & ionic & organs & $3 \times 10^{-3}$ & & $\mathrm{E}$ \\
\hline 55 & ${ }^{137} \mathrm{Cs}$ & Prohl et al. 1989 & 50-yr integra activity calc & beef & $4 \times 10^{-2}$ & & $\mathrm{M}$ \\
\hline 55 & ${ }^{137} \mathrm{Cs}$ & Voigt et al. 1989a & grass cobs & heifer & $3.8 \times 10^{-2}$ & & $\mathrm{E}$ \\
\hline 55 & ${ }^{137} \mathrm{Cs}$ & Ward et al. 1989 & hay 1986 & dairy beef & $5.4-6.9 \times 10^{-3}$ & direct deposit & $\mathrm{E}$ \\
\hline 55 & ${ }^{137} \mathrm{Cs}$ & Ward et al. 1989 & green-chop 1986\&87 & dairy beef & $96 \times 10^{-3}$ & root uptake & $\mathrm{E}$ \\
\hline
\end{tabular}


Table 4.4 (cont'd)

\begin{tabular}{|c|c|c|c|c|c|c|c|}
\hline Atomic \# & Isotope & Reference & Source/form & Tissue & Ff $(\mathrm{d} / \mathbf{k g})$ & Comments & Code \\
\hline 55 & ${ }^{137} \mathrm{Cs}$ & Woodman and Nisbet 1999 & drinking water & beef & $3 \times 10^{-2}$ & model prediction & $\mathrm{M}$ \\
\hline 88 & ${ }^{225 / 226} \mathrm{Ra}$ & IAEA 1994 & model prediction to equilibrium & beef & $9 \times 10^{-4}$ & Morgan and Beetham 1990 & $\mathrm{M}$ \\
\hline 92 & $\mathrm{U}$ & IAEA 1994 & \begin{tabular}{|l|} 
literature review \\
\end{tabular} & beef & $3 \times 10^{-4}$ & Cramp et al. 1990 & $\mathrm{R}$ \\
\hline 93 & $\mathrm{~Np}$ & IAEA 1994 & literature review & beef & $1 \times 10^{-3}$ & & $\mathrm{R}$ \\
\hline 94 & $\mathrm{Pu}$ & IAEA 1994 & model prediction for 100 day & beef & $1 \times 10^{-5}$ & Coughtrey 1990 & $\mathrm{M}$ \\
\hline 94 & $\mathrm{Pu}$ & IAEA 1994 & model prediction for 100 day & veal & $1 \times 10^{-3}$ & Coughtrey 1990 & $\mathrm{M}$ \\
\hline 94 & $\mathrm{Pu}$ & Smith et al. 1977 & field study & beef & $0.5-1.6 \times 10^{-4}$ & derived; Coughtrey 1990 & $\mathrm{~F}$ \\
\hline 94 & $\mathrm{Pu}$ & Smith et al. 1977 & field study & liver & $0.026-6.4 \times 10^{-3}$ & derived; Coughtrey 1990 & $\mathrm{R}$ \\
\hline 94 & $\mathrm{Pu}$ & Garten 1978 & Pu dioxide-19 days of dosing & beef & $5 \times 10^{-9}$ & extrapolation from Stanley et al. 1975 & $\mathrm{E}$ \\
\hline 94 & $\mathrm{Pu}$ & $\mathrm{Ng} 1982 ; \mathrm{Ng}$ et al. $1982 \mathrm{~b}$ & literature review & beef & $1-2 \times 10^{-6}$ & & $\mathrm{M}$ \\
\hline 94 & $\mathrm{Pu}$ & Nair 1984 & model prediction & beef/veal & $8 \times 10^{-7}$ & cited by Coughtrey 1990 & $\mathrm{M}$ \\
\hline 94 & $\mathrm{Pu}$ & Sumerling et al. 1984 & field study & dairy beef & $3 \times 10^{-4}$ & cited by Coughtrey 1990 & $\mathrm{~F}$ \\
\hline 94 & $\mathrm{Pu}$ & Sumerling et al. 1984 & field study & \begin{tabular}{|l|l} 
liver & \\
\end{tabular} & $1.6 \times 10^{-3}$ & cited by Coughtrey 1990 & $\mathrm{~F}$ \\
\hline 94 & ${ }^{239 / 240} \mathrm{Pu}$ & Gilbert et al. 1988 & arid rangeland Nevada & muscle & $1.2 \times 10^{-7}$ & model Fraction from GI & $\mathrm{F}$ \\
\hline 94 & ${ }^{239 / 240} \mathrm{Pu}$ & Gilbert et al. 1988 & arid rangeland Nevada & liver & $1.4 \times 10^{-6}$ & model Fraction from GI & $\mathrm{F}$ \\
\hline 94 & $\mathrm{Pu}$ & Coughtrey 1990 & model prediction & beef & $1-5 \times 10^{-4}$ & derived by Brown & $\mathrm{M}$ \\
\hline 94 & $\mathrm{Pu}$ & Coughtrey 1990 & model prediction & beef & $1 \times 10^{-5}$ & derived by Prohl & $\mathrm{M}$ \\
\hline 95 & ${ }^{241} \mathrm{Am}$ & IAEA 1994 & model prediction for 100 day & liver & $4 \times 10^{-5}$ & Coughtrey 1990 & $\mathrm{M}$ \\
\hline 95 & ${ }^{241} \mathrm{Am}$ & IAEA 1994 & model prediction for 100 day & veal & $1 \times 10^{-3}$ & Coughtrey 1990 & $\mathrm{M}$ \\
\hline 95 & Am & Ng et al. $1982 b$ & literature review & beef & $2.3-3.6 \times 10^{-6}$ & based on collateral data & $\mathrm{R}$ \\
\hline 95 & Am & Nair 1984 & model prediction & beef & $1.6 \times 10^{-6}-4.8 \times 10^{-4}$ & cited by Coughtrey 1990 & $\mathrm{M}$ \\
\hline 95 & $\mathrm{Am}$ & Sumerling et al. 1984 & field study & meat & $5 \times 10^{-4}$ & cited by Coughtrey 1990 & $\mathrm{~F}$ \\
\hline 95 & $\mathrm{Am}$ & Sumerling et al. 1984 & field study & liver & $2.1 \times 10^{-3}$ & cited by Coughtrey 1990 & $\mathrm{~F}$ \\
\hline 95 & $\mathrm{Am}$ & Coughtrey 1990 & model prediction & muscle & $1-5 \times 10^{-4}$ & derived by Brown & $\mathrm{M}$ \\
\hline 95 & $\mathrm{Am}$ & Coughtrey 1990 & model prediction & liver & $2-6 \times 10^{-2}$ & derived by Brown & $\mathrm{M}$ \\
\hline 95 & $\mathrm{Am}$ & Coughtrey 1990 & model prediction & \begin{tabular}{|l|l} 
beef & \\
\end{tabular} & $4 \times 10^{-6}$ & derived by Prohl & $\mathrm{M}$ \\
\hline \multicolumn{6}{|c|}{ Code: $\mathrm{E}$ - controlled animal experiment; F - field study; R - literature review; M - model prediction } & & \\
\hline
\end{tabular}




\section{Table 4.5. Radionuclide Transfer Coefficients for Mutton and Lamb}

\begin{tabular}{|c|c|c|c|c|c|c|c|}
\hline \begin{tabular}{||l|l|} 
Atomic \# \\
\end{tabular} & Isotope & Reference & \begin{tabular}{|c|} 
Source/form \\
\end{tabular} & Tissue & $F f(d / k g)$ & $\begin{array}{r}\text { Comments } \\
\end{array}$ & Code \\
\hline 38 & ${ }^{90} \mathrm{Sr}$ & IAEA 1994 & model prediction at equil. & adult & $4 \times 10^{-2}\left(0.3-4 \times 10^{-2}\right)$ & Coughtrey 1990 & $\mathrm{M}$ \\
\hline 38 & ${ }^{90} \mathrm{Sr}$ & IAEA 1994 & model prediction at equil. & lamb & $3 \times 10^{-1}$ & Coughtrey 1990 & $\mathrm{M}$ \\
\hline 38 & ${ }^{90} \mathrm{Sr}$ & $\mathrm{Ng} 1982$ & literature review & sheep & $1-9 \times 10^{-3}$ & & $\mathrm{R}$ \\
\hline 38 & ${ }^{90} \mathrm{Sr}$ & Woodman and Nisbet 1999 & drinking water & lamb & $3 \times 10^{-3}$ & model prediction & $\mathrm{M}$ \\
\hline 41 & $\mathrm{Nb}$ & IAEA 1994 & literature review & sheep & $3 \times 10^{-4}$ & CEC 1987 & $\mathrm{R}$ \\
\hline 47 & ${ }^{110 \mathrm{~m}} \mathrm{Ag}$ & IAEA 1994 & single dose & ewe liver & $2.7 \times 10^{-4}$ & Beresford et al. 1994 & $\mathrm{E}$ \\
\hline 47 & ${ }^{110 \mathrm{~m}} \mathrm{Ag}$ & Beresford 1989 & lab study-1986 Rye grass & ewe liver & $0.64 \pm 0.098$ & & $\mathrm{E}$ \\
\hline 47 & ${ }^{110 \mathrm{~m}} \mathrm{Ag}$ & Beresford 1989 & lab study-1986 Rye grass & lamb liver & $2.19 \pm 0.307$ & & $\mathrm{E}$ \\
\hline 47 & ${ }^{110 \mathrm{~m}} \mathrm{Ag}$ & Beresford 1989 & field study- 1987 Rye grass & lamb liver & $<1.55$ & & $\mathrm{~F}$ \\
\hline 47 & ${ }^{110 \mathrm{~m}} \mathrm{Ag}$ & Beresford et al. 1994 & $\mathrm{AgNO}_{3}$ & sheep muscle & $2.7 \pm 1.9 \times 10^{-4}$ & & $\mathrm{E}$ \\
\hline 47 & ${ }^{110 \mathrm{~m}} \mathrm{Ag}$ & Beresford et al. 1994 & $\mathrm{AgNO}_{3}$ & sheep liver & 7.1 & & $\mathrm{E}$ \\
\hline 47 & ${ }^{110 \mathrm{~m}} \mathrm{Ag}$ & Beresford et al. 1998b & $\mathrm{AgNO}_{3} 100$ day model & sheep muscle & $3.99 \times 10^{-4}$ & & $\mathrm{E}$ \\
\hline 47 & ${ }^{110 \mathrm{~m}} \mathrm{Ag}$ & Beresford et al. 1998b & $\mathrm{AgNO}_{3}$ - at equilibrium & sheep muscle & 3.38 & & $\mathrm{E}$ \\
\hline 47 & ${ }^{110 \mathrm{~m}} \mathrm{Ag}$ & Beresford et al. 1998b & $\mathrm{AgNO}_{3} 100$ day model & sheep liver & 4.36 & & $E$ \\
\hline 47 & ${ }^{110 \mathrm{~m}} \mathrm{Ag}$ & Beresford et al. 1998b & $\mathrm{AgNO}_{3}$ - at equilibrium & sheep liver & $4.75 \times 10^{-4}$ & & $\mathrm{E}$ \\
\hline 53 & ${ }^{131} \mathrm{I}$ & IAEA 1994 & lab study & sheep & $3 \times 10^{-2}$ & continuous feeding & $\mathrm{R}$ \\
\hline 55 & ${ }^{137} \mathrm{Cs}$ & IAEA 1994 & model prediction at equel. & sheep & $1.7 \times 10^{-1}\left(0.46-3.5 \times 10^{-1}\right)$ & Coughtrey 1990 & $\mathrm{M}$ \\
\hline 55 & ${ }^{137} \mathrm{Cs}$ & IAEA 1994 & model prediction at equel. & lamb & $4.9 \times 10^{-1}\left(1-16 \times 10^{-1}\right)$ & Coughtrey 1990 & $\mathrm{M}$ \\
\hline 55 & ${ }^{137} \mathrm{Cs}$ & $\mathrm{Ng} 1982$ & literature review & sheep & 0.12 & & \\
\hline 55 & ${ }^{137} \mathrm{Cs}$ & Howard et al. 1989 & ryegrass, feeding study & sheep muscle & $12 \times 10^{-2}$ & & $\mathrm{E}$ \\
\hline 55 & ${ }^{137} \mathrm{Cs}$ & Howard et al. 1989 & ryegrass, feeding study & sheep liver & $5.7 \times 10^{-2}$ & $9.6 \times 10^{-2}$ (kidney) & $\mathrm{E}$ \\
\hline 55 & ${ }^{137} \mathrm{Cs}$ & Howard et al. 1989 & marsh veg, feeding sty & sheep muscle & $1.8 \times 10^{-2}$ & Sellafield & $\mathrm{E}$ \\
\hline 55 & ${ }^{137} \mathrm{Cs}$ & Howard et al. 1989 & marsh veg, feeding sty & sheep liver & $0.7 \times 10^{-2}$ & $1.1 \times 10^{-2}$ (kidney) & $\mathrm{E}$ \\
\hline 55 & ${ }^{137} \mathrm{Cs}$ & Howard et al. 1989 & ryegrass, feeding study & lamb muscle & $50 \times 10^{-2}$ & Chernobyl/UK $\left(60 \times 10^{-2}\right.$ kidney $)$ & $\mathrm{E}$ \\
\hline 55 & ${ }^{137} \mathrm{Cs}$ & Howard et al. 1989 & ryegrass, feeding study & lamb liver & $30 \times 10^{-2}$ & Chernobyl fallout/UK & $\mathrm{E}$ \\
\hline 55 & ${ }^{137} \mathrm{Cs}$ & Howard et al. 1989 & ewes milk, feeding study & lamb muscle & $120 \times 10^{-2}$ & Chernobyl/UK $\left(170 \times 10^{-2}\right.$ kidney $)$ & $\mathrm{E}$ \\
\hline
\end{tabular}


Table 4.5 (cont'd)

\begin{tabular}{|c|c|c|c|c|c|c|c|c|}
\hline & Atomic \# & Isotope & Reference & Source/form & Tissue & Ff (d/kg) & Comments & Code \\
\hline & \begin{tabular}{|l|}
55 \\
\end{tabular} & ${ }^{137} \mathrm{Cs}$ & Howard et al. 1989 & ewes milk, feeding study & lamb liver & $70 \times 10^{-2}$ & Chernobyl fallout/UK & $\mathrm{E}$ \\
\hline & 55 & ${ }^{137} \mathrm{Cs}$ & Voigt et al. 1989a & grass cobs & sheep & $0.3-0.35$ & & $\mathrm{E}$ \\
\hline & 55 & ${ }^{137} \mathrm{Cs}$ & Ward et al. 1989 & hay & sheep & $58 \times 10^{-3}$ & direct deposit & $\mathrm{E}$ \\
\hline & 55 & ${ }^{137} \mathrm{Cs}$ & Ward et al. 1989 & green Chop & \begin{tabular}{|l|l} 
sheep \\
\end{tabular} & $13 \times 10^{-3}$ & \begin{tabular}{|l|} 
root uptake \\
\end{tabular} & $\mathrm{E}$ \\
\hline & 55 & ${ }^{137} \mathrm{Cs}$ & Assimakopoulos et al. 1993b & grass, wheat & sheep muscle & $34 \times 10^{-2}$ & Chernobyl fallout/Greece & $\mathrm{E}$ \\
\hline & 55 & ${ }^{137} \mathrm{Cs}$ & Assimakopoulos et al. 1993b & grass, wheat & sheep liver & $18 \times 10^{-2}$ & Chernobyl fallout/Greece & $\mathrm{E}$ \\
\hline & 55 & ${ }^{137} \mathrm{Cs}$ & Beresford et al. 1998c & ionic & sheep & $0.34 \times 10^{-1}$ & & $\mathrm{E}$ \\
\hline & 55 & ${ }^{137} \mathrm{Cs}$ & Woodman and Nisbet 1999 & drinking water & lamb & 0.5 & model prediction & $\mathrm{M}$ \\
\hline & 94 & $\mathrm{Pu}$ & IAEA 1994 & model prediction -100 day & adult & $9.4 \times 10^{-5}\left(5 \times 10^{-6}-1 \times 10^{-3}\right)$ & Coughtrey 1990 & M \\
\hline & 94 & $\mathrm{Pu}$ & IAEA 1994 & model prediction -100 day & lamb & $3.1 \times 10^{-3}$ & Coughtrey 1990 & $\mathrm{M}$ \\
\hline & 95 & $\mathrm{Pu}$ & Ng 1982 & literature review & lamb & $6.7 \times 10^{-6}$ & based on collateral data & $\mathrm{R}$ \\
\hline & 94 & $\mathrm{Pu}$ & Nair 1984 & model prediction & sheep/lamb & $4.8 \times 10^{-6}$ & cited by Coughtrey 1990 & M \\
\hline & 94 & $\mathrm{Pu}$ & Howard 1985 & field study, saltmarsh & meat & $2.5-3.8 \times 10^{-3}$ & derived data & $\mathrm{F}$ \\
\hline & 94 & $\mathrm{Pu}$ & Howard 1985 & field study, saltmarsh & liver & $0.98-1.1 \times 10^{-2}$ & derived data & $\mathrm{F}$ \\
\hline & 94 & $\mathrm{Pu}$ & Coughtrey 1990 & model prediction & sheep/lamb & $1-6 \times 10^{-3}$ & derived data by Brown & M \\
\hline & 95 & ${ }^{241} \mathrm{Am}$ & IAEA 1994 & model prediction -100 day & adult & $2 \times 10^{-4}\left(9.6 \times 10^{-6}-1 \times 10^{-3}\right)$ & Coughtrey 1990 & M \\
\hline & 95 & ${ }^{241} \mathrm{Am}$ & IAEA 1994 & model prediction -100 day & lamb & $4.1 \times 10^{-3}\left(2.4 \times 10^{-5}-4.1 \times 10^{-3}\right)$ & Coughtrey 1990 & M \\
\hline & 95 & ${ }^{241} \mathrm{Am}$ & Ng 1982 & literature review & lamb & $2.4 \times 10^{-5}$ & based on collateral data & $\mathrm{R}$ \\
\hline & 95 & ${ }^{241} \mathrm{Am}$ & Nair 1984 & model prediction & lamb/sheep & $9.6 \times 10^{-6}$ & cited by Coughtrey 1990 & M \\
\hline & 95 & ${ }^{241} \mathrm{Am}$ & Coughtrey 1990 & model prediction & muscle & $1-6 \times 10^{-3}$ & derived by Brown & M \\
\hline & 95 & ${ }^{241} \mathrm{Am}$ & Coughtrey 1990 & model prediction & liver & $2-5 \times 10^{-1}$ & derived by Brown & M \\
\hline & Code: $\mathrm{E}$ & & ed animal experiment; $\mathrm{F}$ - $\mathrm{f}$ & d study; R - literature rev & $\mathrm{w} ; \mathrm{M}-$ model $\mathrm{p}$ & & & \\
\hline
\end{tabular}


Table 4.6. Transfer Coefficients for Goat Meat

\begin{tabular}{|c|c|c|c|c|c|c|c|}
\hline Isotope \# & Isotope & Reference & Source/form & Tissue & $F_{f}(d / \mathbf{k g})$ & $\begin{array}{r}\text { Comments } \\
\end{array}$ & Code \\
\hline 38 & ${ }^{90} \mathrm{Sr}$ & IAEA 1994 & single \& cont. dose & goat & $2.8 \times 10^{-3}$ & Burov et al. 1969,pp. 19-24 & $\mathrm{E}$ \\
\hline 40 & ${ }^{95} \mathrm{Zr}$ & Johnson et al. 1988 & $\mathrm{Zr}(\mathrm{VI}) \mathrm{Oxalate}$ & goat & $2.0 \times 10^{-5}$ & single administration & $\mathrm{E}$ \\
\hline 41 & ${ }^{95} \mathrm{Nb}$ & Johnson et al. 1988 & $\mathrm{Nb}(\mathrm{III})$ Oxalate & goat & $6.0 \times 10^{-5}$ & single administration & $\mathrm{E}$ \\
\hline 42 & ${ }^{99 m} \mathrm{Tc}$ & Johnson et al. 1988 & $\mathrm{NaTcO}_{4}$ & goat & $2.2 \times 10^{-4}$ & single administration & $\mathrm{E}$ \\
\hline 55 & ${ }^{137} \mathrm{Cs}$ & IAEA 1994 & Model prediction 100 day & goat & $2.3 \times 10^{-1}\left(0.12-3.8 \times 10^{-1}\right)$ & Hansen and Hove 1991; Johnson and Ward 1989 & $\mathrm{E} / \mathrm{M}$ \\
\hline
\end{tabular}


Table 4.7. Radionuclide Transfer Coefficients for Pork

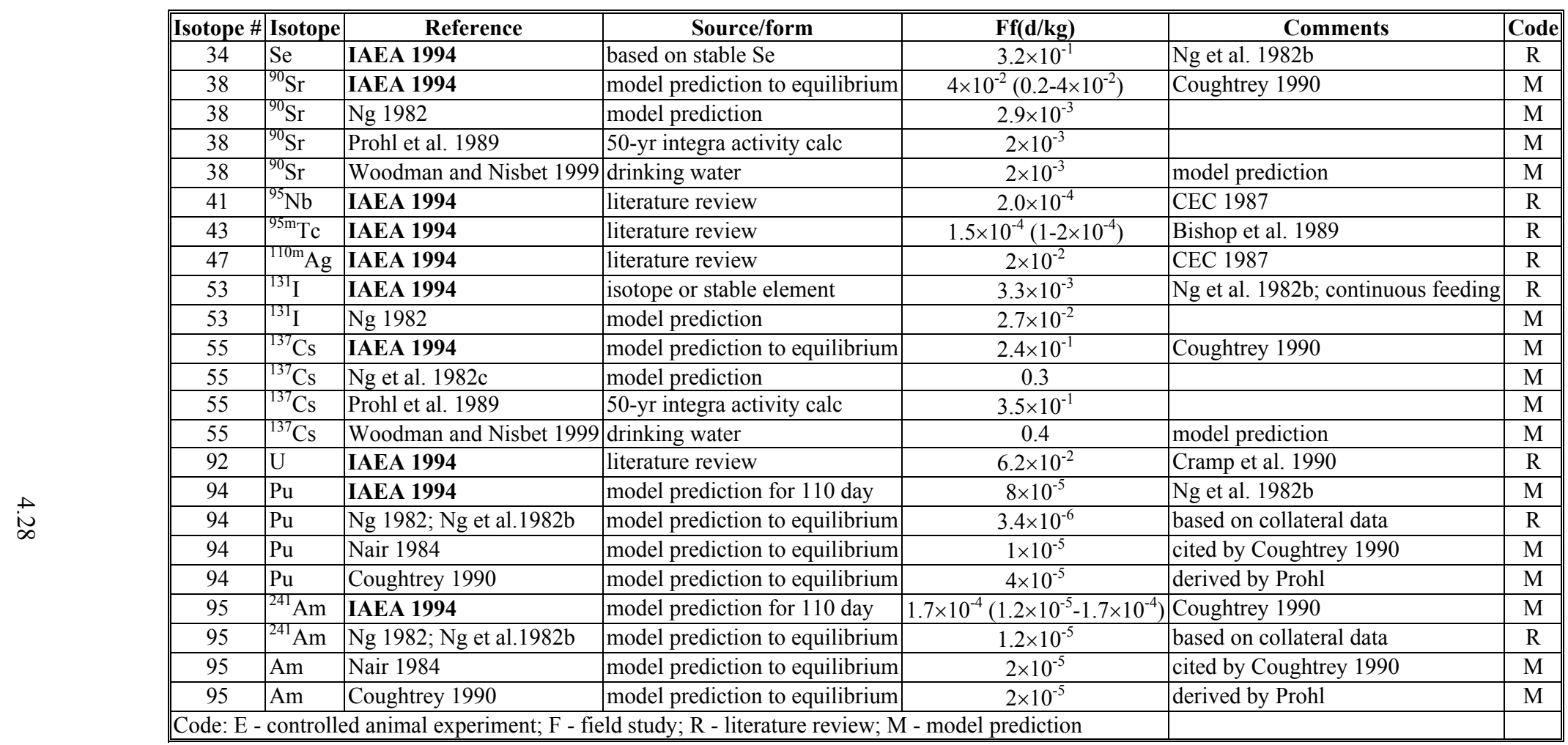


Table 4.8. Radionuclide Transfer Coefficients for Poultry

\begin{tabular}{|c|c|c|c|c|c|c|c|}
\hline Atomic \# & Isotope & Reference & Source/form & Species & Ff (d/kg) & \begin{tabular}{|r|} 
Comments \\
\end{tabular} & Code \\
\hline 34 & ${ }^{75} \mathrm{Se}$ & IAEA 1994 & based on stable $\mathrm{Se}$ & poultry & 9 & $\mathrm{Ng}$ et al. $1982 \mathrm{~b}$ & $\mathrm{M}$ \\
\hline 38 & ${ }^{90} \mathrm{Sr}$ & IAEA 1994 & literature review & poultry & $8 \times 10^{-2}\left(1 \times 10^{-2}-4.0\right)$ & Coughtrey 1990; model prediction & $\mathrm{M}$ \\
\hline 38 & ${ }^{90} \mathrm{Sr}$ & $\mathrm{Ng} 1982$ & model prediction & chicken & $3.2 \times 10^{-2}$ & & \\
\hline 38 & ${ }^{90} \mathrm{Sr}$ & Woodman and Nisbet 1999 & drinking water & broilers & $4 \times 10^{-2}$ & model prediction & $\mathrm{M}$ \\
\hline 38 & ${ }^{90} \mathrm{Sr}$ & Woodman and Nisbet 1999 & drinking water & hen & $3 \times 10^{-1}$ & model prediction & $\mathrm{M}$ \\
\hline 40 & ${ }^{95} \mathrm{Zr}$ & \begin{tabular}{|l|} 
Ennis et al. $1988 \mathrm{~b}$ \\
\end{tabular} & $\mathrm{Zr}(\mathrm{IV})$ oxalate & chicken & $6 \times 10^{-5}$ & single dose & $\mathrm{E}$ \\
\hline 41 & ${ }^{95} \mathrm{Nb}$ & Ennis et al. $1988 b$ & $\mathrm{Nb}(\mathrm{III})$ Oxalate & chicken & $3.0 \times 10^{-4}$ & single dose & $\mathrm{E}$ \\
\hline 42 & ${ }^{99} \mathrm{Mo}$ & Ennis et al. $1988 \mathrm{~b}$ & $\mathrm{MoO}_{3}$ & chicken & $1.8 \pm 0.4 \times 10^{-1}$ & single dose & $\mathrm{E}$ \\
\hline 43 & ${ }^{95 \mathrm{~m}} \mathrm{Tc}$ & Ennis et al. 1988b & $\mathrm{NaTcO}_{4}$ & chicken & $3.3 \pm 1.3 \times 10^{-2}$ & single dose & $\mathrm{E}$ \\
\hline 47 & ${ }^{110 \mathrm{~m}} \mathrm{Ag}$ & IAEA 1994 & literature review & poultry & 2 & CEC 1987 & $\mathrm{M}$ \\
\hline 53 & ${ }^{131} \mathrm{I}$ & Ennis et al. $1988 b$ & $\mathrm{NaI}$ & chicken & $1.1 \times 10^{-2}$ & single dose & $\mathrm{E}$ \\
\hline 55 & ${ }^{137} \mathrm{Cs}$ & IAEA 1994 & model prediction & poultry & $1 \times 10^{-1}(0.3-10)$ & Coughtrey 1990 & $\mathrm{M}$ \\
\hline 55 & ${ }^{137} \mathrm{Cs}$ & Ng 1982; Ng et al. 1982b & single; repeated dosing & poultry & $4.4(4.2-4.6)$ & & $\mathrm{M}$ \\
\hline 55 & ${ }^{137} \mathrm{Cs}$ & Voigt et al. 1993 & grass pellets & leg/breast & $1.2-1.6$ & & $\mathrm{E}$ \\
\hline 55 & ${ }^{137} \mathrm{Cs}$ & Voigt et al. 1993 & wheat & leg/breast & $2.8-3.0$ & & $\mathrm{E}$ \\
\hline 55 & ${ }^{137} \mathrm{Cs}$ & Woodman and Nisbet 1999 & drinking water & broilers & 4.5 & model prediction & $\mathrm{M}$ \\
\hline 55 & ${ }^{137} \mathrm{Cs}$ & Woodman and Nisbet 1999 & drinking water & hen & 0.5 & model prediction & $\mathrm{M}$ \\
\hline 60 & $\mathrm{Nd}$ & IAEA 1994 & collateral data & poultry & $9 \times 10^{-2}$ & $\mathrm{Ng}$ et al. $1982 \mathrm{~b}$ (data from other species) & $\mathrm{M}$ \\
\hline 92 & $\mathrm{U}$ & IAEA 1994 & stable element conc & poultry & $1(0.3-1)$ & $\mathrm{Ng}$ et al. $1982 \mathrm{~b}$ & $\mathrm{M}$ \\
\hline 92 & ${ }^{234 / 238} \mathrm{U}$ & Izak-Biran et al. 1989 & rock phosphate & poultry & $3 \times 10^{-1}$ & derived from concentration data & $\mathrm{E}$ \\
\hline 94 & $\mathrm{Pu}$ & IAEA 1994 & model pred for equilib & poultry & $3 \times 10^{-3}\left(2 \times 10^{-5}-3 \times 10^{-3}\right)$ & Coughtrey 1990 & $\mathrm{M}$ \\
\hline 94 & $\mathrm{Pu}$ & Nair 1984 & model prediction & poultry & $2 \times 10^{-5}$ & cited by Coughtrey 1990 & $\mathrm{M}$ \\
\hline 94 & $\mathrm{Pu}$ & Coughtrey 1990 & model prediction & poultry & $2 \times 10^{-5}-8 \times 10^{-3}$ & derived by Brown & $\mathrm{M}$ \\
\hline 94 & $\mathrm{Pu}$ & $\mathrm{Ng}$ et al. $1982 \mathrm{~b}$ & $\mathrm{Pu}$ citrate & poultry & $1.6 \times 10^{-4}$ & from Mullin 1975; Mullin et al. 1976 & $\mathrm{R}$ \\
\hline 94 & $\mathrm{Pu}$ & Ng et al. $1982 \mathrm{~b}$ & $\mathrm{Pu}$ dioxide & poultry & $1.9 \times 10^{-5}$ & from Mullin 1975; Mullin et al. 1976 & $\mathrm{R}$ \\
\hline 95 & ${ }^{241} \mathrm{Am}$ & IAEA 1994 & model pred for equilib & poultry & $6 \times 10^{-3}$ & Coughtrey 1990 & $\mathrm{M}$ \\
\hline 95 & ${ }^{241} \mathrm{Am}$ & $\mathrm{Ng}$ et al. $1982 \mathrm{~b}$ & Am-citrate & poultry & $1.8 \times 10^{-4}$ & from Mullin 1975; Mullin et al. 1976 & $\mathrm{R}$ \\
\hline 95 & Am & Nair 1984 & model prediction & poultry & $3.6 \times 10^{-8}$ & cited by Coughtrey 1990 & $\mathrm{M}$ \\
\hline 95 & $\mathrm{Am}$ & Coughtrey 1990 & model prediction & poultry & $2 \times 10^{-8}-8 \times 10^{-3}$ & derived by Brown & $\mathrm{M}$ \\
\hline
\end{tabular}


Table 4.9. Radionuclide Transfer Coefficients for Eggs

\begin{tabular}{|c|c|c|c|c|c|c|}
\hline Atomic \# & Isotope & Reference & Source/form & Ff (d/kg) & $\begin{array}{r}\text { Comments } \\
\end{array}$ & Code \\
\hline 34 & ${ }^{75} \mathrm{Se}$ & IAEA 1994 & based on stable $\mathrm{Se}$ & 9 & $\mathrm{Ng}$ et al. $1982 \mathrm{~b}$ & $\mathrm{M}$ \\
\hline 38 & ${ }^{90} \mathrm{Sr}$ & IAEA 1994 & model pred 100 day & $2 \times 10^{-1}\left(2-6 \times 10^{-1}\right)$ & Coughtrey 1990; Johnson and Ward 1989 & $\mathrm{M}$ \\
\hline 38 & ${ }^{90} \mathrm{Sr}$ & Ng 1982 & model prediction & 0.22 & & $\mathrm{M}$ \\
\hline 40 & ${ }^{95} \mathrm{Zr}$ & Ennis et al. $1988 \mathrm{~b}$ & $\mathrm{Zr}(\mathrm{IV})$ oxalate & $2.0 \times 10^{-4}$ & single dose & $\mathrm{E}$ \\
\hline 41 & ${ }^{95} \mathrm{Nb}$ & Ennis et al. $1988 \mathrm{~b}$ & $\mathrm{Nb}(\mathrm{III})$ Oxalate & $1.0 \times 10^{-3}$ & single dose & $\mathrm{E}$ \\
\hline 42 & ${ }^{99} \mathrm{Mo}$ & Ennis et al. $1988 \mathrm{~b}$ & $\mathrm{MoO}_{3}$ & $(8.7 \pm 1.6) \times 10^{-1}$ & single dose & $\mathrm{E}$ \\
\hline 43 & ${ }^{95 \mathrm{~m}} \mathrm{Tc}$ & Ennis et al1988b & $\mathrm{NaTcO}_{4}$ & $3 \pm 0.3$ & single dose & $\mathrm{E}$ \\
\hline 53 & ${ }^{131} \mathrm{I}$ & Ennis et al. $1988 b$ & $\mathrm{NaI}$ & $(3.2 \pm 0.3) \times 10^{-2}$ & single dose & $\mathrm{E}$ \\
\hline 53 & ${ }^{131} \mathrm{I}$ & Ng 1982 & model prediction & 4.4 & & $\mathrm{M}$ \\
\hline 55 & ${ }^{137} \mathrm{Cs}$ & IAEA 1994 & model pred for $100 \mathrm{~d}$ & $4 \times 10^{-2}\left(6 \times 10^{-2}-2\right)$ & Coughtrey 1990 & $\mathrm{R}$ \\
\hline 55 & ${ }^{137} \mathrm{Cs}$ & Voigt et al. 1993 & grass pellets & 0.2 & & $\mathrm{E}$ \\
\hline 55 & ${ }^{137} \mathrm{Cs}$ & Voigt et al. 1993 & wheat & 0.4 & & $\mathrm{E}$ \\
\hline 60 & $\mathrm{Nd}$ & IAEA 1994 & collateral data & $3 \times 10^{-4}$ & $\mathrm{Ng}$ et al. $1982 \mathrm{~b}$ (data from other species) & M \\
\hline 92 & $\mathrm{U}$ & IAEA 1994 & stable element conc & 1 & $\mathrm{Ng}$ et al. $1982 \mathrm{~b}$ & M \\
\hline 92 & ${ }^{234 / 238} \mathrm{U}$ & Izak-Biran et al.1989 & rock phosphate & 1.2 & derived from concentration data & $\mathrm{E}$ \\
\hline 94 & $\mathrm{Pu}$ & IAEA 1994 & model pred at equilib & $5 \times 10^{-4}\left(3 \times 10^{-5}-8 \times 10^{-3}\right)$ & $\mathrm{Ng}$ et al. $1982 \mathrm{~b}$ & $\mathrm{M}$ \\
\hline 94 & $\mathrm{Pu}$ & Coughtrey 1990 & model prediction & $8 \times 10^{-3}$ & derived by Prohl & $\mathrm{M}$ \\
\hline 94 & $\mathrm{Pu}$ & $\mathrm{Ng}$ et al. $1982 \mathrm{~b}$ & Pu-citrate & $6.8 \times 10^{-3}$ & from Mullin 1974; Mullin et al. 1976 & $\mathrm{R}$ \\
\hline 94 & $\mathrm{Pu}$ & $\mathrm{Ng}$ et al. $1982 \mathrm{~b}$ & Pu-dioxide & $2.9 \times 10^{-5}$ & from Mullin 1974; Mullin et al. 1976 & $\mathrm{R}$ \\
\hline 94 & $\mathrm{Pu}$ & Nair 1984 & model prediction & $3 \times 10^{-5}$ & Coughtrey 1990 & $\mathrm{M}$ \\
\hline 95 & ${ }^{241} \mathrm{Am}$ & IAEA 1994 & model pred for equilib & $4 \times 10^{-3}\left(1-9 \times 10^{-3}\right)$ & Coughtrey 1990 & $\mathrm{R}$ \\
\hline 95 & ${ }^{241} \mathrm{Am}$ & Ng et al. $1982 b$ & Am-citrate & $8.5 \times 10^{-3}\left(2 \times 10^{-5}-6 \times 10^{-3}\right)$ & from Mullin 1974; Mullin et al. 1976 & $\mathrm{R}$ \\
\hline 95 & $\mathrm{Am}$ & Nair 1984 & model prediction & $5 \times 10^{-3}\left(2 \times 10^{-5}-6 \times 10^{-3}\right)$ & cited by Coughtrey 1990 & M \\
\hline 95 & $\mathrm{Am}$ & Coughtrey 1990 & model prediction & $8 \times 10^{-3}$ & derived by Prohl & $\mathrm{M}$ \\
\hline
\end{tabular}




\subsection{Section 4 References}

Albers BP, H Steindl, W Schimmack, and K Bunzl. 2000. "Soil-To-Plant and Plant-To-Cow's Milk Transfer of Radiocaesium in Alpine Pastures: Significance of Seasonal Variability." Chemosphere. 41:717-23.

Assimakopoulos PA, KG Ioannides, AA Pakou, and A Mantzios. 1987. "Measurement of the Transfer Coefficient for Radiocesium Transport from a Sheep's Diet to Its Milk." Health Phys. 53:685-689.

Assimakopoulos PA, KG Ioannides, and AA Pakou. 1989. "The propagation of the Chernobyl ${ }^{131}$ I impulse through the air-grass-animal-milk pathway in northwestern Greece." Sci. Total Environ. 85:295-305.

Assimakopoulos PA, KG Ioannides, DT Karamanis, AA Pakou, KC Stamoulis, AS Mantzios, and E Nikolaou. 1993a. "Radiocaesium Transfer to Sheep's Milk as a Result of Soil Ingestion." Sci. Total Environ. 136:13-24.

Assimakopoulos PA, K Divanes, KG Ioannides AA Pakou, KC, AS Mantzios, and CP Pappas. 1993b. "Transport of Radiocaesium to Sheep's Diet to Its Tissues." Sci. Total Environ.136:1-11.

Assimakopoulos PA, K Divanes, AA Pakou, KC Stamoulis, AS Mantzios, and E Nikolaou. 1995. "Radiostrontium Transfer to Sheep's Milk as a Result of Soil Ingestion." Sci. Total Environ.172:17-20.

Belli M, A Drigo, S Menegon, A Menin, P Nazzi, U Sansone, and M Toppano. 1989. "Transfer of Chernobyl Fall-Out Caesium Radioisotopes in the Cow Food Chain." Sci Total Environ. 85:169-177.

Belli M, M Blasi, E Capra, A Drigo, S Menegon, E Piasentier, and U Sansone. 1993. "Ingested Soil as a Source of ${ }^{137}$ Cs to Ruminants." Sci. Total Environ. 31:243-249.

Beresford NA. 1989. "The Transfer of Ag-110m to Sheep Tissues." Sci. Total Environ. 85:81-90.

Beresford NA, and BJ Howard. 1991. "The Importance of Soil Adhered to Vegetation as a Source of Radionuclides Ingested by Grazing Animals.” Sci. Total Environ. 107:237-254.

Beresford NA, RW Mayes, BJ Howard, HF Eayres, CS Lamb, CL Barnett, and MG Segal. 1992. "The Bioavailability of Different Forms of Radiocaesium for Transfer Across the Gut of Ruminants.” Radiat. Protect. Dosimetry. 41:87-91.

Beresford NA, RW Mayes, NMJ Crout, BJ Howard, and B Kanyar. 1994. "Dynamic Behavior of ${ }^{110 \mathrm{~m}} \mathrm{Ag}$ in Sheep Tissues." Health Phys. 66:420-426. 
Beresford NA, RW Mayes, HS Hansen, NMJ Crout, K Hove, and BJ Howard. 1998a. "Generic Relationship Between Calcium Intake and Radiostrontium Transfer to Milk of Dairy Ruminants." Radiat. Environ. Biophys. 37:129-131.

Beresford NA, NMJ Crout, RW Mayes, BJ Howard, and CS Lamb. 1998b. "Dynamic Distribution of Radioisotopes of Cerium, Ruthenium and Silver in Sheep Tissues." J. Environ. Radioactiv. 38:317-338.

Beresford, NA, RW Mayes, CL Barnett, PJ MacEachern, and NM Crout. 1998c. "Variation in the Metabolism of Radiocaesium Between Individual Sheep." Radiat. Environ. Biophys. $37: 277-281$.

Beresford NA, S Gashchak, N Lasarev, A Arkhipov, Y Chyorny, N Arkhipov, RW Mayes, BJ Howard, G Baglay, L Loginova, and N Burov. 2000. "The Transfer of Cs-137 and Sr-90 to Dairy Cattle Fed Fresh Herbage Collected 3.5 Km from the Chernobyl Nuclear Power Plant." J. Environ. Radioactiv. 47:157-170.

Bertilsson J, I Anderson, and KJ Johanson. 1988. "Feeding Green-Cut Forage Contaminated by Radioactive Fallout to Dairy Cows." Health Phys. 55:855-862.

Binnerts WT, FW Lengemann, and CL Comar. 1962. "Radioiodine metabolism in the goat after simultaneous single and daily administration.” J. Dairy Sci. 45:427-431.

Bishop GP, CJ Beetham, and YS Cuff. 1989. "Review of literature for chlorine, technetium, iodine and neptunium." Nirex Radioactive Waste Disposal Safety Studies, Rep. NSS/R193, UK Nirex Ltd, Harwell.

Blincoe C, VR Bohman, and DD Smith. 1981. "The Ingestion of Plutonium and Americium by Range Cattle." Health Phys. 41:285-291.

Bradley EJ, and BT Wilkins. 1989. "Influence of Husbandry on the Transfer of Radiocaesium from Feed to Milk During the Winter that Followed the Chernobyl Reactor Accident." Sci Total Environ. 85:119-128.

Bruenger FW, W Stevens, and BJ Stover. 1969. "Americium-241 in Blood: In Vivo and Invitro Observation." Radiat. Res. 37:349-360.

Burov NJ, NN Antakora, IY Pancheko, and IA Sarapul'tsev. 1969. "Buildup and distribution of Sr-90 in sheep and goats under single and chronic administration." Radioactive Isotopes and the Body (YI Moscaley, Ed.), Rep. AEC-tr7195, Department of Energy, Washington, D.C.

Comar CL, RH Wasserman, and AR Twardock. 1961. "Secretion of Calcium Strontium Into Milk." Health Phys. 7:67-80.

Comar CL, RH Wasserman, and FW Lengemann. 1966. "Effect of Dietary Calcium on Secretion of Strontium into Milk.” Health Phys. 12:1-6. 
Commission of the European Communities (CEC). 1987. Radionuclide Transfer Factors for Animal Feedingstuff and Animal Products, Doc. 7682/87, Luxembourg.

Conrad HR and AL Moxon. 1979. "Transfer of Dietary Selenium to Milk." J. Dairy Sci. 62:404-411.

Cooke AI, N Green, DL Rimmer, TE Weekes, BT Wilkins, NA Beresford, and JDFenwick. 1996. "Absorption of Radiocaesium by Sheep After Ingestion of Contaminated Soils." Sci. Total Environ.192:21-29.

Cooper JR, and HS Gowing. 1981. "The Binding of Americium and Curium to Human Serum Protiens." Int. J. Radiat. Biol. 40:569-572.

Coughtrey PJ, D Jackson, CH Jones, and MC Thorne. 1984. Radionuclide Distribution and Transport in Trerrestrial and Aquatic Ecosystems. A Critical Review of Data, Vols 3 and 4, Balkema, Rotterdam.

Coughtrey PJ. 1990. Radioactivity Transfer to Animal Products. Rep. EUR 12608 EN, Commision of the European Communities, Luxembourg.

Cramp TJ, YS Cuff, A Davis, and JE Morgan. 1990. Review of Data for Uranium, Nickel and Cobalt. Rep. 2151-RI, Associated Nuclear Services Ltd. Epsom.

Crout NMJ, NA Beresford, RW Mayes, PJ MacEachern, CL Barnett, CS Lamb and BJ Howard. 2000. "A Model of Radioiodine Transfer to Goat Milk Incorporating the Influence of Stable Iodine." Radiat. Environ. Biophys. 39:59-65.

Dostal LA, SM Hopfer, SM Lin, and FW Sunderman, Jr. 1989. "Effects of Nickel Chloride on Lactating Rats and Their Suckling Pups, and the Transfer of Nickel Through Rat Milk." Toxicol. Appl. Pharmacol. 101:220-231.

Eisele GR, SR Bernard, and CW Nestor, Jr. 1987. "Gastrointestinal Absorption of Americium241 by Orally Exposed Swine: Comparison of Experimental Results with Predictions of Metabolic Models." Radiat. Res. 112:62-73.

Ennis ME, Jr., JE Johnson, and G.M Ward. 1988a. "A Specific Activity Effect in the Metabolism of Tc." Health Phys. 54:157-160.

Ennis ME Jr., GM Ward, JE Johnson, and KN Boamah. 1988b. "Transfer Coefficients of Selected Radionuclides to Animal Products. II. Hen Eggs and Meat.” Health Phys. 54:167-170.

Ennis ME Jr., JE Johnson, GM Ward, and KN Boamah. 1989. “Technetium Metabolism by Lactating Goats." Health Phys. 57:321-330. 
Fabbri S, G Piva, R Sogni, G Fusconi, E Lusardi, and G Borasi. 1994. "Transfer Kinetics and Coefficients of ${ }^{90} \mathrm{Sr},{ }^{134} \mathrm{Cs}$, and ${ }^{137} \mathrm{Cs}$ from Forage Contaminated by Chernobyl Fallout to Milk of Cows." Health Phys. 66:375-379.

Fredricksson L, and A Ericksson. 1966. "Studies on the transport of fission products through food chains." In: ${ }^{137}$ Cs in vegetation and milk at the experimental farms of Swedish Agricultural College in 1963. FOA-4-4484.

Garten CT, Jr. 1978. “A Review of Parameter Values Used to Assess the Transport of Plutonium, Uranium, and Thorium in Terrestrial Food." Environ Res. 17:437-52.

Gastberger M, F Steinhausler, MH Gerzabek, and A Hubmer. 2001. "Fallout Strontium and Caesium Transfer from Vegetation to Cow Milk at Two Lowland and Two Alpine Pastures." J. Environ. Radioact. 54:267-273.

Gerber GB, M van Hees, CT Garten, Jr., CM Vandecasteele, J Vankerkom, R van Bruwaene, R Kirchmann, J Colard J, and M Cogneau. 1998. "Technetium Absorption and Turnover in Monogastric and Polygastric Animals." Health Phys. 57:315-319.

Gilbert RO, DW Engel, and LR Anspaugh. 1989. "Transfer of Aged ${ }^{239+240} \mathrm{Pu},{ }^{238} \mathrm{Pu},{ }^{241} \mathrm{Am}$, and ${ }^{137} \mathrm{Cs}$ to Cattle Grazing a Contaminated Arid Environment." Sci. Total Environ. 85:53-62.

Gilbert RO, DW Engel, DD Smith, JH Shinn, LR Anspaugh, and GR Eisele. 1988. "Transfer of Aged Pu to Cattle Grazing on a Contaminated Arid Environment." Health Phys. 54:323-335.

Handl J and A Pfau. 1987. "Feed-Milk Transfer of Fission Products Following the Chernobyl Accident." Atomernenergie-Kerntechnik 49:171-173.

Handl J, and A Pfau. 1989. "Long-Term Transfer of I-129 Into the Food Chain." Sci. Total Environ. 85:245-252.

Handl J, A Pfau, and FW Huth. 1990. "Measurement of ${ }^{129}$ I in Human and Bovine Thyroids in Europe-Transfer of ${ }^{129}$ I into the Food Chain." Health Phys. 58:609-618.

Hansen HS, and K Hove. 1991. "Radiocesium Bioavailability: Transfer of Chernobyl and Tracer Radiocesium to Goat Milk." Health Phys. 60:665-73.

Harrison JD. 1991. "The Gastrointestinal Absorption of the Actinide Elements." Sci. Total Environ. 100:43-60.

Hawthorne HA, SD Zellmer, LL Eberhardt, and JM Thomas. 1976. “ ${ }^{137}$ Cesium Cycling in a Utah Dairy Farm.” Health Phys. 30:447-464.

Hoffman FO. 1978. "A Review of Measured Values of the Milk Transfer Coefficient $\left(\mathrm{F}_{\mathrm{m}}\right)$ for Iodine." Health Phys. 35:413-416. 
Hoffman FO, E Amaral, DA Mohrbacher, and E Deming. 1988. "The comparison of generic model predictions with Chernobyl fallout data on the transfer of radioiodine over the air-pasturecow-milk pathway." J. Environ. Radioact. 8:53-71.

Howard BJ. 1985. "Aspects of the Uptake of Radionuclides by Sheep Grazing on an Estuarine Saltmarsh. 1. The Influence of Grazing Behaviour and Environmental Variability on Daily Intake.” J. Environ. Rad 2:183-198.

Howard BJ, RW Mayes, NA Beresford, and CS Lamb. 1989. "Transfer of Radiocesium from Different Environmental Sources to Ewes and Suckling Lambs." Health Phys. 57:579-586.

Howard BJ, NA Beresford, RW Mayes, and CS Lamb. 1993. "Transfer of ${ }^{131}$ I to sheep milk from vegetation contaminated by Chernobyl fallout." J. Environ. Radioact. 19:155-161.

Howard BJ, NA Beresford, RW, Mayes, H.S Hansen, NM Crout, and K Hove. 1997. "The Use of Dietary Calcium Intake of Dairy Ruminants to Predict the Transfer Coefficient of Radiostrontium to Milk." Radiat. Environ. Biophys. 36:39-43.

International Atomic Energy Agency (IAEA). 1994. Handbood of Parameter Values for the Prediction of Radionuclide Transfer in Temperate Environmnets. Technical Report Series No. 364, Vienna, Austria.

Izak-Biran T, T Schlesinger, R Weingarten, O Even, Y Shamai, and M Israeli. 1989. "Concentrations of U and Po in Animal Feed Supplements, in Poultry Meat and in Eggs." Health Phys. 56:315-319.

Johnson JE, GM Ward, E Firestone, and KL Knox. 1968. "Metabolism of Radioactive Cesium $\left({ }^{134} \mathrm{Cs}\right.$ and $\left.{ }^{137} \mathrm{Cs}\right)$ and Potassium by Dairy Cattle as Influenced by High and Low Forage Diets." J. Nutr. 94:282-288.

Johnson JE, TR Tyler, and G.M Ward. 1969. "Transfer of Fallout Cesium-137 from Feed to Meat of Cattle." J. Anim. Sci. 29:695-699.

Johnson JE, GM Ward, ME Ennis, Jr., and KN Boamah. 1988. "Transfer Coefficients of Selected Radionuclides to Animal Products. I. Comparison of Milk and Meat from Dairy Cows and Goats." Health Phys. 54:161-166.

Johnson JE, and GM Ward. 1989. Screening Models to Predict Food-chain transfer of environmental toxicants. Final Rep. DOE/ER/6053-1, Colorado State University, Fort Collins, $\mathrm{CO}$.

Jones BE. 1989. "Technetium Metabolism in Goats and Swine." Health Phys. 57:331-336.

Kahn B, IR Jones, MW Carter, PJ Robbins, and CP Staub. 1965. "Changes in Milk Composition and Urine Output in Rations Composed of Different Ratios of Flaked Corn and Alfalfa Hay.” J. Dairy Sci. 48:809. 
Kennedy WE, Jr., and DL Strenge. 1992. Residual Radioactive Contamination from Decommissioning. NUREG/CR-5512. PNL-7994. Richland, WA.

Kirchner G. 1989. "Analysis of the transport of Chernobyl fallout nuclides through the pasturecow-milk food chain using a time-dependent model." In: The proceedings of the XVth regional congress of the International Radiological Protection Association. W Feldt, ed., Koln: Verlag TUV Rheinland, p. 196-201.

Kirchner G. 1994. "Transport of Iodine and Cesium Via the Grass-Cow-Milk Pathway After the Chernobyl Accident." Health Phys. 66:653-665.

Lengemann FW, and CL Comar. 1964. "Metabolism of 131I by Dairy Cows During LongTerm Daily Administration of the Radioesotope." Health Phys. 10:55-59.

Lengemann FW. 1970. "Metabolism of radioiodine by lactating goats given iodine-131 for extended periods." J. Dairy Sci. 53:165-170.

Lengemann FW, and RA Wentworth. 1978. "The transfer coefficient of 137Cs into cows milk as related to the level of milk production." Health Phys. 34:720-722.

Martin CJ, B Heaton, and J Thompson. 1989. "Cesium-137, ${ }^{134} \mathrm{Cs}$ and ${ }^{110 \mathrm{~m}}$ ag in Lambs Grazing Pasture in NE Scotland Contaminated by Chernobyl Fallout." Health Phys. 56:459-464.

Mayes RW. 1989. "The Quantification of Dietary Intake, Digestion and Metabolism in Farm Livestock and Its Relevance to the Study of Radionuclide Uptake." Sci. Total Environ. 85:29-51.

Mayes RW, and CS Lamb. 1989. "A possible method for estimating the true coefficient for radiocaesium in ruminants." Sci. Total Environ. 85:263-266.

Mayes RW, HF Eayres, NA Beresford, CS Lamb, and BJ Howard. 1992. "Changes with Age in the Absorption of Radiocesium by Sheep." Radiation Protection Dosimetry. 41: 83-86.

McClellan RO, H.W Casey, and LK Bustad. 1962. "Transfer of Some Transuranic Elements to Milk." Health Phys. 8:689-694.

Morgan JE, and CJ Beetham. 1990. "Review of literature for radium, protactimium, tin and carbon.” Nirex Radioactive Waste Disposal Safety Studies, UK Nirex Ltd. Harwell.

Moss BW, EF Unsworth, CH McMurray, J Pearce, and DJ Kilpatrick. 1989. "Studies on the Uptake, Partition and Retention of Ionic and Fallout Radiocaesium by Suckling and Weaned Lambs." Sci. Total Environ. 85:91-106.

Mullen AL, RE Stanley, SR Lloyd, and AA Moghissi. 1972. "Radioberyllium Metabolism by the Dairy Cow." Health Phys. 22:17-22. 
Mullen AA. 1974. Distribution of Ingested Plutonium in Chickens and Subsequent Transport to Eggs. NVO-142:213-220, Nevada Operations Office, Las Vegas, NV.

Mullen AA, SR Lloyd, and RE Mosley. 1976. "Distribution of Ingested Transuranium Nuclides in Chickens and Subsequent Transport to Eggs." In: Transuranium Nuclides in the Environment. IAEA. International Atomic Energy Agency.

Mullen AA, SR Lloyd, RE Mosley, GD Potter, and RG Patzer. 1977. Absorption, Distribution, and Milk Secretion of Neptunium in the Dairy Goat. NVO-181:267-279, Nevada Operations Office. Las Vegas, NV.

Nair S. 1984. Models for the evaluation of ingestion doses from the consumption of terrestrial foods following an atmospheric radioactive release. CEGB Berkley. RD/B/5200/N84.

Ng YC. 1982. A Review of Transfer Factors for Assessing the Dose from Radionuclides in Agricultural Products. Nucl. Safety. 23:57-71.

Ng YC, CS Colsher, and SE Thompson. 1982a. Transfer Coefficients for Assessing the Dose from Radionuclides in Meat and Eggs. Final Rep. to USNRC, NUREG/CR-2976, UCID-19464, Lawrence Livermore National Laboratory, Livermore, CA.

Ng YC, CS Colsher, DJ Quinn, and SE Thompson. 1982b. Transfer Coefficients for the Prediction of the Dose to Man via the Forage-Cow-Milk Pathway from Radionuclides Released to the Biosphere. Rep. UCRL-51939, Lawrence Livermore National Laboratory, Livermore, CA.

Patzer GG, WW Sutton, PB Hahn, and GD Potter. 1977. Comparison of curium-234 and plutonium-238 biological transport in dairy animals following intravenous injections. NVO181:243-265. Nevada Operations Office. Las Vegas, NV.

Pearce J, CH McMurray, EF Unsworth, BW Moss, FJ Gordon, and DJ Kilpatrick. 1989. "Studies of the Transfer of Dietary Radiocaesium from Silage to Milk in Dairy Cows." Sci. Total Environ, 85:267-278.

Pietrzak-Flis Z, L Rosiak, MM Suplinska, E Chrzanowski, S and Dembinska. 2001. "Daily Intakes of ${ }^{238} \mathrm{U},{ }^{234} \mathrm{U},{ }^{232} \mathrm{Th},{ }^{230} \mathrm{Th},{ }^{228 \mathrm{Th}}$, and ${ }^{226} \mathrm{Ra}$ in the Adult Population of Central Poland." Sci. Total Environ. 273:163-169.

Porter CR, CR Phillips, MW Carter, and B Kahn. 1966. “The Cause of Relatively High ${ }^{137} \mathrm{Cs}$ Concentrations in Tampa, Florida Milk Radioecological Concentration Processes." In Proceedings of an International Symposium, Stockhom, Sweden, 25-29 April 1996, pp. 95-101. Pergamon Press, NY. 
Prohl G, H Muller, and G Voigt. 1989. "The influence of the Feeding Practice and the Season on the Contamination of Animal Food Products After a Single Deposition of Radionuclides." Sci. Total Environ. 85:107-117

Sasser LB. 1965. The uptake and secretion of iodine-131 by lactating dairy cows resulting for a contaminated pasture. MS Thesis, Colorado State University, Fort Collins, CO.

Sasser LB, and CA Hawley, Jr. 1966. "Sectetion of I-131 into Milk Under Conditions of Environmental Contamination of Pasture." J. Dairy Sci. 49:1505-1510.

Sam D, WF Williams, DD Rockman, and JT Allen. 1980. "Transfer Coefficients of Radionuclides Secreted in Milk of Dairy Cows.” J. Dairy Sci. 63:1447-14450.

Sansom BF. 1964. "Transfer of Plutonium-239 from the Diet of a Cow to Its Milk." Brit. Vet J. 120:36-39.

Shaw G. 2001. "Radioecology-How Did We Get Here and What Do We Do Now." J. Environ. Radioact. 54:305-309.

Smith DD, KR Giles, and DE Bernhardt. 1977. Animal Investigation Program. 1973 Annual Report. Nevada Test Site and Vicinity. EMSL-LV-0539-3, Nevada Operations Office. Las Vegas, NV.

Stanley RE, EW Bretthauer, and WW Sutton. 1975. Absorption, Distribution, and Milk Excretion of Plutonium by Dairy Cattle. NVO-153 (UC-2) pp. 97-124. Nevada Operations Office, Las Vegas, NV.

Stewart HF, G.M Ward, and JE Johnson. 1965. "Availability of Fallout ${ }^{137}$ Cs to Dairy Cattle from Different Types of Feed.” J. Dairy Sci. 48:1-5.

Stover BJ, FW Bruenger, and W Stevens. 1968. "The Reaction of Pu(IV) in the Iron Transport Stem in Human Blood Serum." Radiat. Res. 33:381-394.

Sullivan MF, BM Miller, and JC Goebel. 1984. "Gastrointestinal Absorption of Metals $\left({ }^{51} \mathrm{Cr}\right.$,

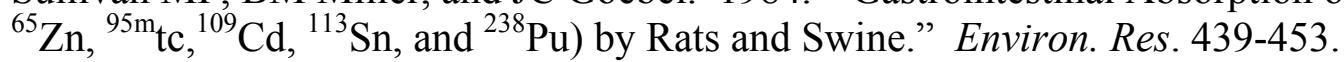

Sullivan MF, BM Miller, PS Ruemmler and JL Ryan. 1985. "Further Studies on the Influence of Chemical Form and Dose on Absorption of $\mathrm{Np}, \mathrm{Pu}, \mathrm{Am}$ and $\mathrm{Cm}$ from the Gastrointestinal Tracts of Adult and Neonatal Rodents." Health Phys. 48:61-73.

Sullivan MF, and PS Ruemmler. 1988. "Absorption of ${ }^{233} \mathrm{U},{ }^{237} \mathrm{~Np},{ }^{238} \mathrm{Pu},{ }^{241} \mathrm{Am}$ and ${ }^{244} \mathrm{Cm}$ from the Gastrointestinal Tracts of Rats Fed an Iron-Deficient Diet." Health Phys. 54:311-316.

Sumerling TJ, N Green, and NJ Dodd. 1984. "Uptake of Radionuclides by Farm Animals Close to a Major Nuclear installation." In: Radiation-Risk-Protection, pp. 156-159. IRPA Congress. Berlin. 
Sutton WW, and AA Mullen. 1977. Transport of Plutonium via Food Products of Animals. NVO-178:435-448. Nevada Operations Office, Las Vegas, NV.

Thomas JM, LL Cadwell, DA Cataldo, TR Garland, and RE Wildung. 1984. "Concentration of Orally Administered and Chronically Fed ${ }^{95 \mathrm{~m}}$ Tc in Japanese Quail Eggs." Health Phys. 46:657-663.

Thornton I, and P Abrahams. 1983. "Soil Ingestion--a Major Pathway of Heavy Metals into Livestock Grazing Contaminated Land.” Sci. Total Environ. 28:287-294.

Underwood EJ. 1976. "Mineral Imbalances in Farm Animals and Their Study and Diagnosis with Isotopic Tracers.” Atomic Energy Rev. 144:591-619.

Vandecasteele CM, M Van Hees, F Hardeman, G Voigt, and BJ Howard. 2000. "The True Absorption of I-131, and Its Transfer to Milk in Cows Given Different Stable Iodine Diets." J Environ Radioactiv. 47:301-317.

Van den Hoek J, RJ Kirchmann, J Colard, and JE Sprietsma JE. 1969. "Importance of Some Methods of Pasture Feeding, of Pasture Type and of Seasonal Factors on ${ }^{85} \mathrm{Sr}$ and ${ }^{134} \mathrm{Cs}$ Transfer from Grass to Milk." Health Phys. 17:691-700.

Vankerkom J, M van Hess, CM Vandecasteele, JP Culot, and GB Gerber. 1988. "Transfer to farm animals (ruminants) and their products of Cs-134 and I-131 after the Chernobyl accident." In: Proc. $4^{\text {th }}$ Int. Sym. On Radioecology impact of Accidents of Nuclear Origin on the Environment. CEN/CEA, Cadarache, France. 111-119.

Voigt G, K Henrichs, G Prohl, and HG Paretzke. 1988. "Measurements of Transfer Coefficients for ${ }^{137} \mathrm{Cs},{ }^{60} \mathrm{Co},{ }^{54} \mathrm{Mn},{ }^{22} \mathrm{Na},{ }^{131} \mathrm{I}$ and ${ }^{95 \mathrm{~m}}$ tc Feed into Milk and Beef." Radiat. Environ. Biophys. 27:143-152.

Voigt G, G Prohl, H Muller, H Bauer, JP Lindner, G Probstmeier, and G Rohrmoser. 1989a. "Determination of the Transfer of Cesium and Iodine from Feed into Domestic Animals." Sci. Total Environ. 85:329-338.

Voigt G, H Muller, G Prohl, H.G Paretzke, G Propstmeier, G Rohrmoser, and P Hofmann. 1989b. "Experimental Determination of Transfer Coefficients of ${ }^{137} \mathrm{Cs}$ and ${ }^{131} \mathrm{I}$ from Fodder into Milk of Cows and Sheep After the Chernobyl Accident." Health Phys. 57:967-973.

Voigt G, H Muller, HG Paretzke, T Bauer, and G Rohrmoser. 1993. " ${ }^{137}$ Cs Transfer After Chernobyl from Fodder into Chicken Meat and Eggs." Health Phys. 65:141-146.

Voigt G, C Schotola, G Probstmeier, and G Rohrmoser. 1994. "Influence of Stable Iodine on the Transfer of ${ }^{131}$ I into Cows' Milk." Radiat. Environ. Biophys. 33:243-250. 
Voors PI, and AW Van Weers. 1989. "Transfer of Chernobyl ${ }^{134} \mathrm{Cs}$ and ${ }^{137} \mathrm{Cs}$ in Cows from Silage to Milk." Sci. Total Environ. 85:179-88.

Vreman K, TD van der Struijs, J van den Hoek, PL.Berende, and PW Goedhart. 1989.

"Transfer of Cs-137 from Grass and Wilted Grass Silage to Milk of Dairy Cows." Sci. Total Environ. 85:139-47.

Ward GM, and JE Johnson. 1965. "The Cesium-137 Content of Beef from Dairy and Feed-Lot Cattle." Health Phys. 11:95-100.

Ward GM, and JE Johnson. 1986. "Validity of the Term Transfer Coefficient." Health Phys. 50:411-414.

Ward GM, and JE Johnson. 1989. “Assessment of Milk Transfer Coefficients for Use in Prediction Models of Radioactivity Transport.” Sci. Total Environ. 85:287-294.

Ward GM, JE Johnson, and LB Sasser. 1967. "Transfer Coefficients of Fallout Cesium-137 to Milk of Dairy Cattle Fed Pasture, Green Cut Alfalfa or Stored Feed.” J. Dairy Sci. 50:10921096.

Ward GM, Z Keszthelyi, B Kanyar, UP Kralovanszky, and JE Johnson. 1989. "Transfer of ${ }^{137}$ Cs to Milk and Meat in Hungary from Chernobyl Fallout with Comparisons of Worldwide Fallout in the 1960." Health Phys. 57:587-592.

Watkins BM, GM Smith, RH Little, and J Kessler. 1999. “A Biosphere Modeling Methodology for Dose Assessments of the Potential Yucca Mountain Deep Geological High Level Radioactive Waste Repository." Health Phys. 76:355-367.

Woodman RF, and AF Nisbet. 1999. "Derivation of Working Levels for Radionuclides in Animal Feedstuffs for Use Following a Nuclear Accident. Health Phys. 77:383-91.

Zach R and KR Mayoh. 1984. "Soil Ingestion by Cattle: a Neglected Pathway." Health Phys. 46:426-431. 


\subsection{Modeling Radionuclide Behavior in Soil, Plants, and Animals}

\subsection{Introduction}

Models applicable to regulatory situations vary according to their intended uses. Requirements for features and processes that are simulated are different for models used to respond to accidents than for models used to predict doses from future geochemical or geohydrological transport. The discussion presented here assumes that regulatory models for evaluating radioactive waste disposal or decommissioned sites are needed. For such models, the dynamics of most processes are unimportant, and only the integral or average exposure is estimated. In general, models used for predicting future behavior are applied to situations where conditions change slowly, and annual average modeling is appropriate.

\subsection{Soil Models}

The soil model used in the current versions of NRC codes such as GENII Version 1.485 (Napier et al. 1988) or GENII-S (Leigh et al. 1992) is illustrated in Figure 5.1. This model allows calculation of surface soil concentrations of radionuclides as a function of time with consideration of 1) leaching from surface soil, 2) deposition from air to surface soil, 3) irrigation deposition from water to surface soil, and 4) loss from surface soil from plant harvest. The soil model is applied separately for each exposure pathway allowing different soil concentrations to be used to evaluate each exposure pathway. For example, different soil concentrations are usually defined for leafy vegetable crops consumed directly by humans and for forage crops used by milk animals.

Figure 5.1 shows the primary compartment considered in the model, the surface zone. The surface soil is the portion on which deposition from the atmosphere and irrigation occurs, and that from which resuspension occurs. Radionuclides may be lost from the surface soil through harvest removal, radiological decay, and leaching out of the surface soil layer. This type of formulation is common to many models, such as GENII (Napier et al. 1988), RESRAD (Yu et al. 2002), ECOSYS (Mueller and Prohl 1993), and PATHWAY (Whicker and Kirchner 1987). All losses from the surface zone (harvest removal or leaching) are assumed to leave the system. Figure 5.1 also shows a subsurface soil zone and a subsurface waste-package compartment. These compartments are only used in analyses in which an initial contamination is postulated, such as might exist at a low-level waste-disposal site or the site of a past liquid leak. These compartments serve as sources to the surface soil, but there is no feedback from the surface soil to these compartments in most models.

The surface soil model shown in Figure 5.1 allows evaluation of the soil concentration over the intake period, accounting for prior atmospheric deposition and prior irrigation-water deposition. The soil model can be used to evaluate the soil concentration at the start of the intake period. After the start of intake, the soil model is used to follow the change in soil compartment concentrations as intake is evaluated. The deposition from prior years of deposition (air and water) is evaluated using atmospheric-deposition and water-concentration data provided as a function of time. The analysis is performed on an annual basis, using average atmospheric 
deposition and water concentrations for each year. The models and sub-models defined in the following section are applied on an annual basis as indicated by the time-period parameter, $\mathrm{T}_{\mathrm{yr}}$, representing a 1-year time period.

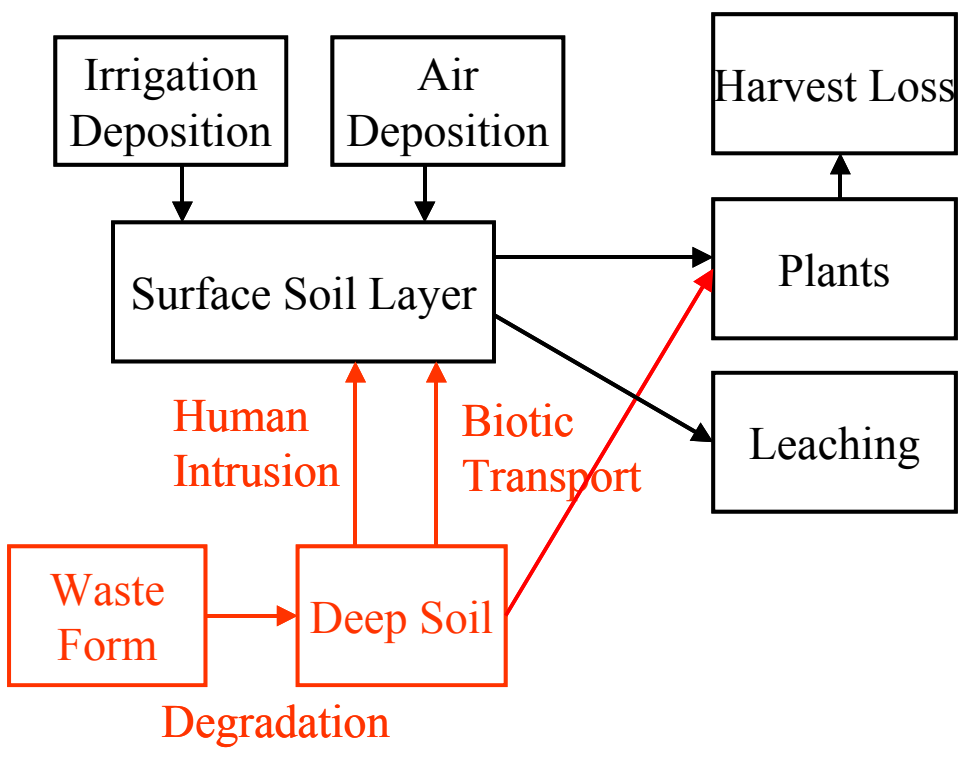

Figure 5.1. Generic Model for Radionuclide Transport in Surface Soils

The concentration of radionuclides in the surface soil compartment is defined by a differential equation that describes the change of concentration in surface soil as a function of time. For chronic releases, the initial amount in the surface soil is set to zero. The decrease from harvest is modeled as a step function following the time of harvest and does not appear in the differential equation for the surface zone. The differential equation for chronic releases for the surface-soil zone is as follows:

$$
\frac{\mathrm{d} \mathrm{A}_{\mathrm{i}}(\mathrm{t})}{\mathrm{dt}}=\left(\mathrm{R}_{\mathrm{bi}}+\mathrm{R}_{\mathrm{ai}}\right)-\left(\lambda_{\mathrm{Li}}+\lambda_{\mathrm{i}}\right) \mathrm{A}_{\mathrm{i}}
$$

where

$$
\begin{aligned}
\mathrm{A}_{\mathrm{i}}(\mathrm{t}) & =\text { amount of radionuclide } \mathrm{i} \text { in the surface soil zone at time, } \mathrm{t} \text { (atoms) } \\
\mathrm{R}_{\mathrm{bi}} & =\text { rate of input from irrigation water (atoms/y) } \\
\mathrm{R}_{\mathrm{ai}} & =\text { rate of input from atmospheric deposition (atoms/y) } \\
\lambda_{\mathrm{i}} & =\text { rate constant for radioactive decay of radionuclide } \mathrm{i}\left(\mathrm{y}^{-1}\right) \\
\lambda_{\mathrm{Li}} & =\text { rate constant for leaching of radionuclide from the surface soil zone }\left(\mathrm{y}^{-1}\right) .
\end{aligned}
$$

The differential equation for surface soil includes terms for deposition from air and irrigation water, which are based on amount deposited per unit area. The initial amounts are set to be zero. The amount at the end of a year is evaluated based on the amount present at the beginning of a year plus the amount deposited during the year. The concentration in the soil is the amount in a unit area of the soil divided by the mass of soil assigned to that unit area (a "soil areal density"). 
Radionuclide deposition mechanisms are nearly always phrased in terms of amount per unit area per unit time. To convert the deposition per unit area to a concentration per unit mass, an area density is assigned. This is the mass of soil in an area to a selected depth. Thus, it is actually a several-part assumption: the physical density of the soil and the depth to which the contaminant is assumed to be mixed. The product of the density and the depth is the areal density. In the GENII codes, the mixing depth is defined to be a constant $15 \mathrm{~cm}(6 \mathrm{in}$.). This is assumed to represent the depth to which plowing or other agricultural practices mix the soil on an annual basis (so that 1-year's deposition is mixed into the rooting zone and available for plant uptake). The code MEPAS (Strenge and Chamberlain 1995) allows user inputs, but the defaults are $15 \mathrm{~cm}$ (6 in.) for agricultural soils, and $4 \mathrm{~cm}$ (1.6 in.) for residential soils. The PATHWAY model uses $25 \mathrm{~cm}$ (10 in.). ECOSYS uses $10 \mathrm{~cm}$ (4 in.) for pastures and $25 \mathrm{~cm}(10 \mathrm{in}$.) for plowed soil. The NCRP screening model (NCRP 1999) conservatively uses $5 \mathrm{~cm}$ (2 in.). Because of its primary use as a code for remediation of previously contaminated soils, the RESRAD default is $200 \mathrm{~cm}$ (79 in.). The calculated soil concentration is inversely related to this assumption.

Removal from the surface soils through leaching into deeper soils is treated by means of a soilremoval-rate constant. The models in GENII, in RESRAD, in MEPAS (Strenge and Chamberlain 1995), described in NUREG/CR-5512 (Kennedy and Strenge 1992), and Till and Meyer (1983) all follow the same structure. (The MILDOS model [Strenge and Bander 1981] is similar, but uses a constant 50-year leaching half-time for all contaminants.) For surface soils, the rate constant, $\lambda_{\mathrm{si}}$, is a correction for long-term leaching of deposited radionuclides out of the surface soil (rooting and resuspension zones). The values for $\lambda_{\mathrm{si}}$ are calculated using the formula of Baes and Sharp (1981):

$$
\lambda_{\mathrm{si}}=\frac{10^{-2}(\mathrm{P}+\mathrm{I}-\mathrm{E})}{\mathrm{d}_{\mathrm{s}} \theta_{\mathrm{s}}\left[1+\frac{10^{3} 10^{-6} \rho_{\mathrm{s}}}{\theta_{\mathrm{s}}} \mathrm{Kd}_{\mathrm{si}}\right]}
$$

where

$$
\begin{aligned}
\lambda_{\mathrm{si}} & =\text { removal-rate constant for activity of radionuclide } \mathrm{i} \text { in the surface soil layer }\left(\mathrm{y}^{-1}\right) \\
\mathrm{P} & =\text { total annual precipitation }(\mathrm{cm} / \mathrm{y}) \\
\mathrm{I} & =\text { total irrigation rate }(\mathrm{cm} / \mathrm{y}) \\
\mathrm{E} & =\text { total evapotranspiration rate }(\mathrm{cm} / \mathrm{y}) \\
\rho_{\mathrm{s}} & =\text { surface soil bulk density }\left(\mathrm{kg} / \mathrm{m}^{3}\right) \\
\theta_{\mathrm{s}} & =\text { surface soil volumetric water content }\left(\mathrm{mL} / \mathrm{cm}^{3}\right) \\
\mathrm{Kd}_{\mathrm{si}} & =\text { surface soil distribution coefficient for radionuclide } \mathrm{i}(\mathrm{mL} / \mathrm{g}) \\
10^{-2} & =\text { units conversion factor }(\mathrm{m} / \mathrm{cm}) \\
10^{3} & =\text { units conversion factor }(\mathrm{g} / \mathrm{kg}) \\
10^{-6} & =\text { units conversion factor }\left(\mathrm{m}^{3} / \mathrm{mL}\right)
\end{aligned}
$$

In general, because precipitation is variable and because it is difficult to calculate the evapotranspiration, the $\mathrm{P}+\mathrm{I}-\mathrm{E}$ term is approximated as a constant "overwatering" term. 
The factor describing mobility (or transportability) of radionuclides in soil is the Kd. This term is empirical and rarely easily available for specific soils in specific locations. Frequently, measurements may be poor; for very insoluble materials, sometimes experiments may measure precipitation into a solid rather than reversible sorption. The values provided with the GENII Version 1.485 code are poorly documented.

Some models have slightly more sophisticated surface soil zone models. The ECOSYS, PATHWAY, and MACCS (Jow et al. 1990) models include a second mechanism for effective removal of radionuclides from the soil for plant uptake consisting of a second rate constant for "fixation" of contaminants. In these models, the radionuclide is bound to receptor sites in the soil and immobilized. In these models, the radionuclide is no longer mobile, so it is not available for plant uptake, although it still contributes to external exposure. More sophisticated models have been proposed, e.g., Schreckhise (1980) (shown in Figure 5.2); these models require a substantially increased number of parameters and can be functionally reduced to the simpler models described above.

None of the models reviewed include considerations of surface erosion, although this could be rationalized that material removed from one surface may deposit on another nearby. None consider more complex geochemical processes such as colloidal transport in the vadose zone. None addresses other physical mixing mechanisms like bioturbation. In all models, except the NUREG/CR-5512 model in certain cases, materials leached from the surface soil are "lost"they are no longer considered in the exposure assessment. None have addressed solubility limits, which are considered to be potentially important in some circumstances (NRC 2002).

Loss of activity from the surface soil zone by harvest is modeled as a step function applied at the end of each calculational year. The amount of loss is calculated from the plant concentration at harvest, the annual plant yield, and the soil concentrations at harvest. The calculation is represented by the following equation.

$$
\mathrm{C}_{\mathrm{si}}\left(\mathrm{t}_{+}\right)=\mathrm{C}_{\mathrm{si}}\left(\mathrm{t}_{-}\right)\left[\left(C_{s i}-\mathrm{C}_{\mathrm{ci}}\left(\mathrm{Th}_{\mathrm{c}}\right) \mathrm{Y}_{\mathrm{c}}\right) / C_{s i}\right]
$$

where

$$
\begin{aligned}
\mathrm{C}_{\mathrm{si}}\left(\mathrm{t}_{+}\right)= & \text {surface-soil concentration at soil location } \mathrm{s} \text { for radionuclide } \mathrm{i} \text { after correction for } \\
& \text { harvest removal at time } \mathrm{t}\left(\mathrm{Bq} / \mathrm{m}^{2}\right) \\
\mathrm{C}_{\mathrm{si}}\left(\mathrm{t}_{-}\right)= & \text {surface-soil concentration at soil location } \mathrm{s} \text { for radionuclide } \mathrm{i} \text { before correction } \\
& \text { for harvest removal at time } \mathrm{t}\left(\mathrm{Bq} / \mathrm{m}^{2}\right) \\
\mathrm{C}_{\mathrm{ci}}\left(\mathrm{Th}_{\mathrm{c}}\right)= & \text { crop-c concentration for radionuclide } \mathrm{i} \text { at time of harvest }(\mathrm{Bq} / \mathrm{kg}) \\
\mathrm{Y}_{\mathrm{c}}= & \text { annual yield of crop c }\left(\mathrm{kg} / \mathrm{m}^{2}\right) .
\end{aligned}
$$

The multiplicative term represents the average fraction of the contaminant in soil to that in crops over the year; this term is used rather than a simple subtraction of amount harvested because, for short-lived radionuclides, the amount harvested over the year may actually be larger than the amount remaining in the soil at the end of the year. 


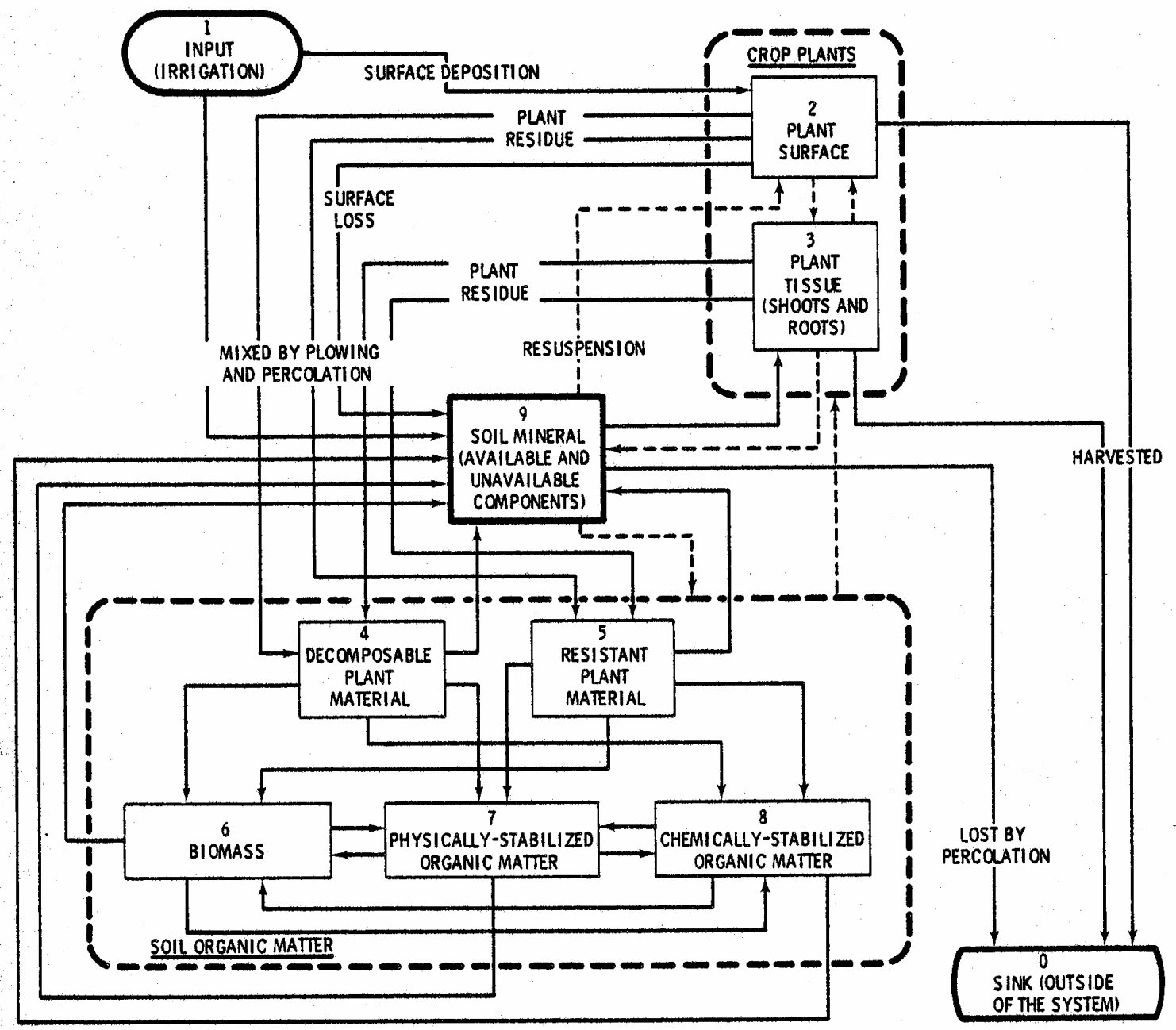

Figure 5.2. More Complex Soil Model (from Schreckhise 1980)

Application of the soil model for the case of continuous irrigation with a contaminated source results in the estimated concentration of contaminant in soil increasing with time until it reaches equilibrium. At equilibrium, the input rate equals the combined loss rates through decay, leaching, and harvest. For mobile radionuclides (those with small Kd values), the equilibrium can occur within a few years of the initiation of irrigation, as illustrated in Figure 5.3. However, for radionuclides with a large $\mathrm{Kd}$, and a small soil-to-plant uptake (which minimizes harvest loss), the approach to equilibrium soil concentration can take hundreds to thousands of years (Figure 5.3). This leads to the requirement for an additional input - the length of time irrigation is assumed to occur before the exposure of the individual under consideration. Most codes, such as GENII, MEPAS, or RESRAD, can be set to assume that the irrigation begins either at the time the exposure scenario begins, or at some time before that to allow for buildup. Once irrigation starts, it is assumed to continue at a constant annual rate (there may be seasonal starts and stops). 


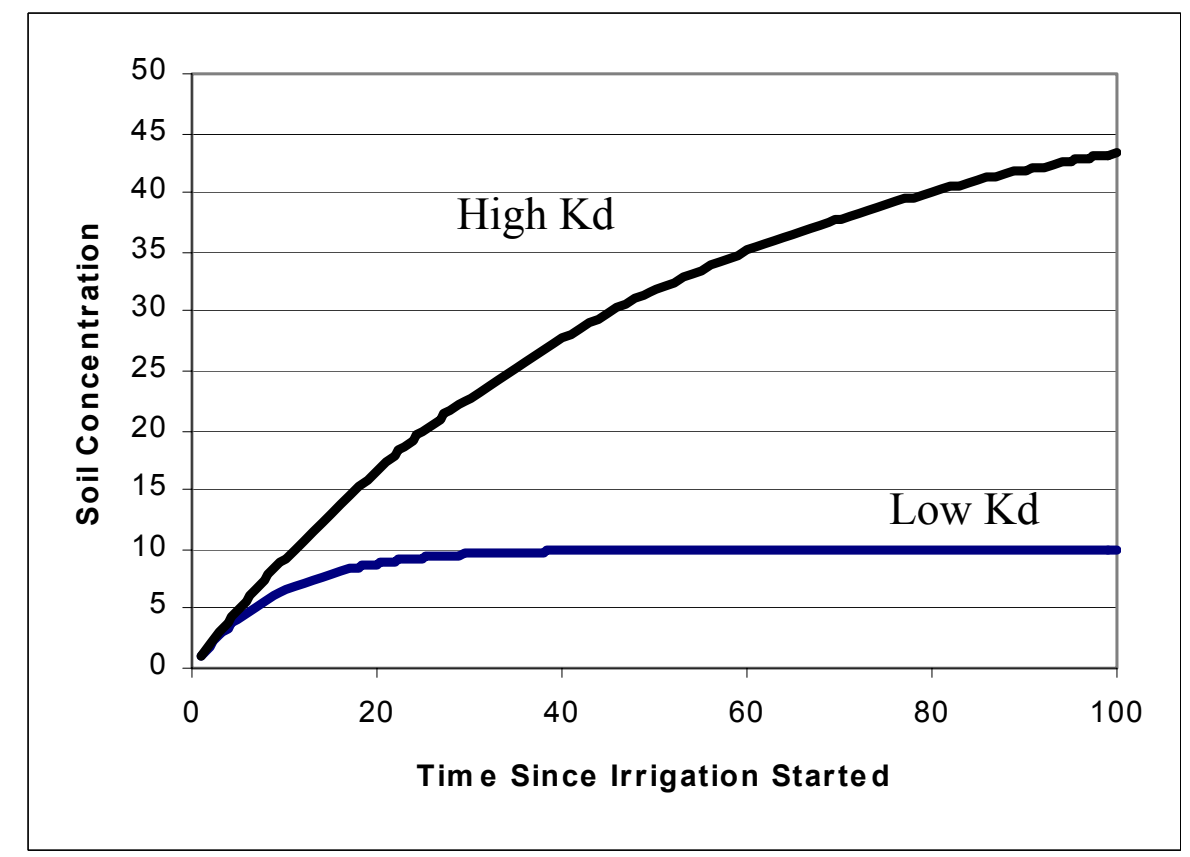

Figure 5.3. Idealized Behavior of Radionuclide Concentration in Soil Following Long Periods of Irrigation for Mobile and Immobile Radionuclides

An example application of an irrigation model is provided by the Hanford Site System Assessment Capability (SAC) (Bryce et al. 2002). In the most recent modeling application using the SAC, irrigation is assumed to start at all locations simultaneously at some fixed time following Hanford Site closure and continue indefinitely (Bryce et al. 2002). A slightly different example is provided by the analyses performed for the Yucca Mountain Project. In these analyses, the start time for the irrigation scenario was generated randomly, followed by a random period of time before exposure. Because the Yucca Mountain analyses use pre-calculated Biosphere Dose Conversion Factors, the analyses fit a set of factors generated for different periods of time following initiation of irrigation to an exponential curve The analyses also used the curve fit as a simple means of evaluating the impacts of long periods of irrigation (Wasiolek 2001). Both the Hanford and Yucca Mountain analyses are projected for very long times into the future (up to 10,000 years). Continuous irrigation has taken place for much shorter periods (about 100 years) in the United States, in California and Colorado. Increasing salinity in soils is a long-term problem. It is still an open question whether irrigation can continue for millennia.

The concentrations and depth distributions of radionuclides in soil have implications for other parts of the modeling scenario. Approaches to estimating direct external dose rates from materials in soil depend on the assumed distribution, as do those for estimating soil-to-plant uptake. 


\subsection{Direct External Dose Rates}

Nearly all computer codes for predicting radiation dose to people that include the pathway of direct irradiation from radionuclides in soil use an infinite source approximation. The source may be considered to be either an infinite flat plane or an infinite slab of a defined thickness. Tabulated dose-rate conversion factors are generally available, e.g., Federal Guidance Report 12, for plane and slab geometries. Often, plane source approximations are used for codes that model acute atmospheric depositions following accidents because it may be reasonably assumed that the deposited contaminants are on or near the soil surface. Most chronic codes assume some sort of slab in which the contaminants are uniformly mixed. The precalculated dose-rate conversion factors are available for several thicknesses of slab. For radionuclides with gamma emissions of relatively low energies, attenuation of the radiation within the soil layer may be significant. Therefore, the geometry in which the radionuclides are mixed is important. Thicker soil slabs have a lower concentration of deposited material and higher attenuation.

The GENII family of codes uses dose-rate conversion factors calculated for a 15-cm (6-in.) thick soil layer. These may be adequate for chronic situations, but may underestimate the dose rate resulting from acute depositions from accidental releases. Other codes that use plane sources should generally overestimate doses in most situations. In cases where the user can influence the assumed thickness, it is necessary to assure that the assumptions used in the concentration determination are also reflected in the selection of dose-rate factors.

\subsection{Simulation of Plants}

The most basic acceptable model of vegetation with respect to modeling of contamination processes is illustrated in Figure 5.4. The plant consists of two simple compartments- the internal mass of the plant and the outside surface. The concentration in plants at the time of harvest is evaluated as the sum of contributions from deposition onto plant surfaces plus uptake through the roots. The contribution from deposition includes deposition directly onto plant surfaces from the air (dry and wet deposition), deposition from material resuspended from soil, and material deposited from irrigation water. Weathering losses from plant-surfaces harvest is also included. The plant concentration at harvest from deposition pathways is evaluated as follows.

$$
\begin{gathered}
\mathrm{C}_{\mathrm{dci}}\left(\mathrm{T}_{\mathrm{yr}}\right)=\left[\mathrm{R}_{\mathrm{id}} \mathrm{r}_{\mathrm{dc}}+\mathrm{R}_{i \mathrm{w}} \mathrm{r}_{\mathrm{wc}}+3.15 \mathrm{E} 7 \mathrm{C}_{\mathrm{ci}}\left(\mathrm{T}_{\mathrm{yr}}\right) \mathrm{RF}_{\mathrm{c}} \mathrm{Vd}_{\mathrm{i}} \mathrm{r}_{\mathrm{ac}}+\mathrm{R}_{\mathrm{wi}} \frac{12 \mathrm{r}_{i \mathrm{c}}}{\mathrm{M}_{\mathrm{c}}}\right] \\
\frac{\mathrm{TV}_{\mathrm{c}}}{\mathrm{B}_{\mathrm{c}}}\left[\frac{1-\mathrm{e}^{-\lambda_{\mathrm{ci}} \mathrm{Tg}_{\mathrm{c}} 2.74 \mathrm{E}-3}}{\lambda_{\mathrm{ei}}}\right]
\end{gathered}
$$

where

$$
\begin{aligned}
\mathrm{C}_{\mathrm{dci}}\left(\mathrm{T}_{\mathrm{yr}}\right)= & \text { concentration of radionuclide } \mathrm{i} \text { on plant type } \mathrm{c} \text { at harvest from deposition processes } \\
& \text { for a } 1 \text {-year period }(\mathrm{Bq} / \mathrm{kg} \text { wet weight }) \\
\mathrm{T}_{\mathrm{yr}}= & 1 \text {-year exposure period }(\mathrm{y})
\end{aligned}
$$


$\mathrm{R}_{\mathrm{id}}=$ constant dry deposition rate of radionuclide $\mathrm{i}\left(\mathrm{Bq} / \mathrm{m}^{2} \mathrm{y}\right)$

$\mathrm{R}_{\mathrm{iw}}=$ constant wet deposition rate of radionuclide $\mathrm{i}\left(\mathrm{Bq} / \mathrm{m}^{2} \mathrm{y}\right)$

$\mathrm{R}_{\mathrm{wi}}=$ constant deposition rate of radionuclide $\mathrm{i}$ from irrigation $\left(\mathrm{Bq} / \mathrm{m}^{2} \mathrm{y}\right)$

$\mathrm{r}_{\mathrm{dc}}=$ interception fraction from airborne dry deposition for plant type $\mathrm{c}$ (dimensionless)

$\mathrm{r}_{\mathrm{wc}}=$ interception fraction for airborne wet deposition to plant type $\mathrm{c}$ (dimensionless)

$\mathrm{C}_{\mathrm{ci}}\left(\mathrm{T}_{\mathrm{yr}}\right)=$ average concentration of radionuclide $\mathrm{i}$ in farmland soil for crop type $\mathrm{c}$ for the current 1-year period $\left(\mathrm{Bq} / \mathrm{m}^{2}\right)$

$\mathrm{RF}_{\mathrm{c}}=$ resuspension factor for crop soil $\left(\mathrm{m}^{-1}\right)$

$\mathrm{Vd}_{\mathrm{i}}=$ deposition velocity of radionuclide $\mathrm{i}(\mathrm{m} / \mathrm{s})$

$12=$ months per year $(\mathrm{mo} / \mathrm{y})$

$\mathrm{r}_{\mathrm{ic}}=$ interception fraction for irrigation deposition to plant type c (dimensionless), generally equal to $r_{w c}$

$\mathrm{M}_{\mathrm{c}}=$ irrigation period for plant type $\mathrm{c}(\mathrm{mo})$

$\mathrm{TV}_{\mathrm{c}}=$ translocation factor for plant type $\mathrm{c}$ (dimensionless)

$\mathrm{B}_{\mathrm{c}}=$ total standing biomass for plant type $\mathrm{c}\left(\mathrm{kg}\right.$ wet weight $\left./ \mathrm{m}^{2}\right)$

$\lambda_{\mathrm{ei}}=$ effective loss-rate constant from plant surfaces representing weathering and radioactive decay for radionuclide i $\left(\mathrm{y}^{-1}\right)$

$\lambda_{\mathrm{ei}}=\lambda_{\mathrm{wi}}+\lambda_{\mathrm{I}}$

$\lambda_{\mathrm{wi}}=$ weathering-rate constant for crops for radionuclide $\mathrm{i}\left(\mathrm{y}^{-1}\right)$

$\mathrm{Tg}_{\mathrm{c}}=$ crop-growing period for plant type c (d)

$3.15 \mathrm{E} 7=$ units conversion factor $(\mathrm{sec} / \mathrm{y})$

2.74E-3 = units conversion factor $(\mathrm{y} / \mathrm{d})$.

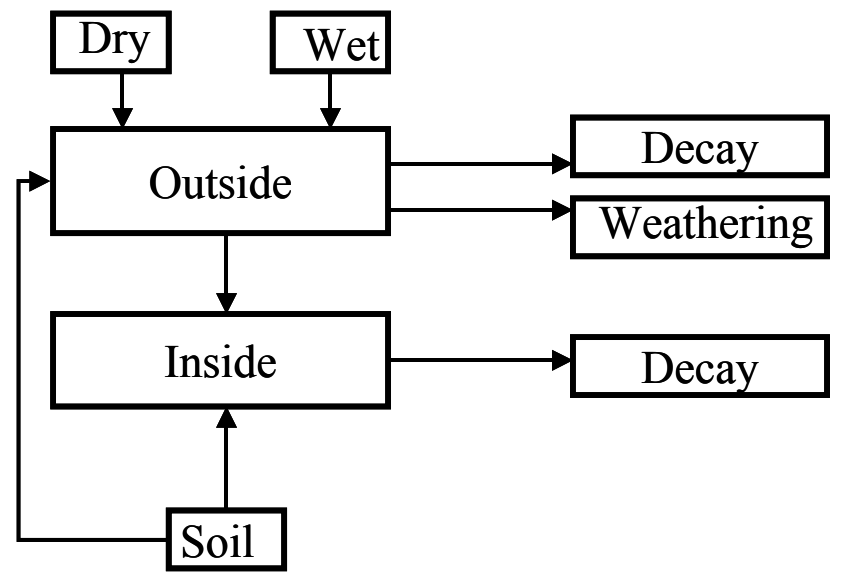

Figure 5.4. A Basic Model for Contamination of Plants 
The plants are also contaminated from root uptake from surface soil. The plant concentration at harvest from root uptake pathways is evaluated as follows.

$$
\mathrm{C}_{\mathrm{rci}}\left(\mathrm{T}_{\mathrm{yr}}\right)=\frac{\mathrm{C}_{\mathrm{ci}}\left(\mathrm{T}_{\mathrm{yr}}\right) \mathrm{Bv}_{\mathrm{ci}} \mathrm{f}_{\mathrm{c}}}{\mathrm{P}}
$$

$\mathrm{C}_{\mathrm{rci}}\left(\mathrm{T}_{\mathrm{yr}}\right)=$ concentration of radionuclide $\mathrm{i}$ in crop type $\mathrm{c}$ from root uptake pathways for a 1 -year period (Bq/kg wet weight)

$\mathrm{Bv}_{\mathrm{ci}}=$ concentration ratio for root uptake of radionuclide $\mathrm{i}$ in crop type $\mathrm{c}(\mathrm{Bq} / \mathrm{kg}$ dry plant per Bq/kg dry soil)

$\mathrm{f}_{\mathrm{c}}=$ dry-to-wet ratio for plant type c ( kg dry plant/kg wet plant)

$\mathrm{P}=$ areal soil density of farmland soil $\left(\mathrm{kg} / \mathrm{m}^{2}\right)$

$\mathrm{RP}_{\mathrm{sc}}=$ fraction of plant type $\mathrm{c}$ roots in surface soil zone (dimensionless).

The total concentration in the plant at the time of harvest is the sum of the contributions from deposition pathways and root-uptake pathways.

$$
\mathrm{C}_{\mathrm{hci}}\left(\mathrm{T}_{\mathrm{yr}}\right)=\mathrm{C}_{\mathrm{dci}}\left(\mathrm{T}_{\mathrm{yr}}\right)+\mathrm{C}_{\mathrm{rci}}\left(\mathrm{T}_{\mathrm{yr}}\right)
$$

where $C_{\text {hii }}\left(T_{y r}\right)$ is the concentration in plant type $\mathrm{c}$ at harvest for a 1-year period $(\mathrm{Bq} / \mathrm{kg}$ wet weight), and other terms are as previously defined.

Each of the key terms in the equations for plant contamination is a potential factor requiring investigation.

\subsubsection{Interception Fractions}

The fraction of material passing by the plane of the plant on its way to the soil surface that is initially captured by the plant is called the interception fraction. This may differ for wet or dry deposition. The deposition fraction in reality is probably a function of the plant biomass (the amount of vegetation per unit area), the size and type of the leaves (often measured as a leaf area index), the nature of the leaf surface (smooth, fuzzy), and even whether it is day or night. Interception fractions are needed for sprinkler irrigation deposition and for dry and wet deposition from air.

Many models, e.g., RESRAD, MEPAS, and CAP88-PC (Chaki and Parks 2000), use a constant dry interception fraction of 0.25 . The MILDOS code uses 0.2 . More sophisticated models that at least account for biomass have been proposed. An empirical relationship between biomass and interception fraction from atmospheric dry deposition was originally suggested by Chamberlain (1967). This model has been expanded by Pinder et al. (1988) for grasses and other species. The following form of the equation is suggested:

$$
\mathrm{r}_{\mathrm{dc}}=1-\mathrm{e}^{-A \mathrm{Y}_{\mathrm{c}} \mathrm{f}_{\mathrm{c}}}
$$


where

$\mathrm{r}_{\mathrm{dc}}=$ interception fraction for atmospheric dry deposition to crop type c (dimensionless)

$\mathrm{A}=$ empirical constant, about 2.9 for grasses, leafy vegetables, and grains, and 3.6 for fruits and other vegetables

$Y_{c}=$ standing biomass of the growing vegetation for crop type $\mathrm{c}\left(\mathrm{kg}\right.$ wet weight $\left./ \mathrm{m}^{2}\right)$

$\mathrm{f}_{\mathrm{c}}=$ dry-to-wet weight biomass ratio for crop type c (kg dry weight per kg wet weight).

The dry-to-wet ratio is required because the Pinder formulations are given in terms of dry biomass. This formulation results in the need to define the growing biomass as well as the harvested yield. Default values used by the GENII family of codes for biomass and dry-to-wet ratio are given in Table 5.1.

Table 5.1. Harvested Yield, Standing Biomass, and Ratio of Dry to Wet Vegetation Used in Interception and Harvest Removal Models

\begin{tabular}{|c|c|c|c|}
\hline Category & $\begin{array}{l}\text { Harvested }^{(\mathbf{a})} \text { Yield } \\
\text { (wet) for Soil } \\
\text { Removal }\end{array}$ & $\begin{array}{l}\text { Standing } \\
\text { Biomass (wet) for } \\
\text { Interception }\end{array}$ & $\begin{array}{c}\text { Dry-to-Wet }^{(\mathrm{c})} \text { Ratio } \\
\text { for Interception }\end{array}$ \\
\hline Leafy Vegetables & 2.0 & 2.0 & 0.10 \\
\hline Other Vegetables & 4.0 & 2.0 & 0.25 \\
\hline Grain & 0.6 & 0.8 & 0.18 \\
\hline Fruit & 2.0 & 3.0 & 0.18 \\
\hline Meat: Forage/Hay & $2.0^{(\mathrm{d})}$ & 1.0 & 0.20 \\
\hline Meat: Grain & 0.6 & 0.8 & 0.18 \\
\hline Poultry \& Eggs Grain & 0.6 & 0.8 & 0.18 \\
\hline Milk: Fresh Forage & $3.0^{(\mathrm{d})}$ & 1.5 & 0.20 \\
\hline Milk: Hay & $2.0^{(\mathrm{d})}$ & 1.0 & 0.20 \\
\hline \multicolumn{4}{|c|}{$\begin{array}{l}\text { (a) Adapted from data in Shor et al. (1982) for areas with highly productive agriculture. } \\
\text { (b) Derived from data in Shor et al. (1982), Strenge et al. (1987), or Napier et al. (1980). } \\
\text { (c) Adapted from Till and Meyer (1983), Section 5. } \\
\text { (d) Multiple cuttings. }\end{array}$} \\
\hline
\end{tabular}

The interception of material in irrigation water, $\mathrm{r}_{\mathrm{ic}}$, is not well studied. Thus, a default value of 0.25 is often used for all materials deposited on all plant types by irrigation. The interception fraction for wet deposition can be evaluated as a function of the rainfall rate and standing biomass based on experimental observations of Prohl and Hoffman (1993). The data by Prohl and Hoffman were used to develop relationships for anions, cations, and for insoluble particles for the GENII Version 2 application (Napier et al. 2002; Napier 2002). For anions, such as iodide and sulfate, the interception fraction is evaluated as follows:

$$
r_{w c}=2.3 Y_{c} f_{c} R^{-0.92}
$$


where

$\mathrm{r}_{\mathrm{wc}}=$ interception fraction from wet deposition to crop type c (dimensionless)

$\mathrm{Y}_{\mathrm{c}}=$ standing biomass of the growing vegetation for crop type $\mathrm{c}\left(\mathrm{kg}\right.$ wet weight $\left./ \mathrm{m}^{2}\right)$

$\mathrm{f}_{\mathrm{c}}=$ dry-to-wet weight biomass ratio for crop type c (kg dry weight per kg wet weight)

$\mathrm{R}=$ rainfall rate $(\mathrm{mm} / \mathrm{d})$.

For particles, Prohl and Hoffman presented the following relationship based on experiments using microspheres.

$$
\mathrm{r}_{\mathrm{wc}}=2.95 \mathrm{Y}_{\mathrm{c}} \mathrm{f}_{\mathrm{c}} \mathrm{R}^{-0.191}
$$

where terms are as previously defined.

Beyeler et al. (1999) also evaluated the results of Hoffman and Prohl. Beyeler et al. (1999) decided that it was difficult to assign anion/cation status without site-specific knowledge of groundwater chemistry and selected to use a single range of interception fractions. They recommend a central value of about 0.35 within a uniform range of from 0.1 to 0.6 for all crop types.

The ECOSYS code uses a formulation based on Leaf Area Index and the water-storage capacity of plant leaves. Buildup of the water film on the leaves during wetting events, the total amount of water deposited, and the radionuclide's ability to be fixed on the leaf (another interpretation of the data of Hoffman and Prohl) are considered. In this formulation, the wet interception fraction is estimated as

$$
r_{w c}=L A I_{i} S_{i} / R\left[1-\exp \left(\frac{-\ln 2}{3 S_{i}} R\right)\right]
$$

where LAI is the leaf area index of plant $\mathrm{I}, \mathrm{S}_{\mathrm{i}}$ is the retention coefficient for plant type $\mathrm{I}(\mathrm{mm})$, and $\mathrm{R}$ is the amount of rainfall $(\mathrm{mm})$.

If this equation results in an interception fraction greater than one, the value is set to one. Muller and Prohl (1993) provide estimates for the retention coefficient. As for the modified Chamberlain model described above, these vary for grasses, cereals, and corn, and for other plants.

\subsubsection{Contamination of Plant Surfaces with Soil}

Plants may acquire surficial contamination in the form of dust or splashed-up soil; the source is the soil in which the plant is growing. In Equation 5.4, this process is parameterized as consisting of resuspension of contaminated soil followed by local redeposition. This is the approach taken by the GENII family of codes, as well as RESRAD, PATHWAY, and ECOSYS. The model described in NUREG/CR-5512 uses a somewhat different parameterization, applying 
a "loading" of soil directly onto the plant. For radionuclides with concentration ratios greater than about 0.01 , this is a minor process. However, for contaminants with low concentration ratios that are not appreciably taken up by plants, such as plutonium, this may be the dominant pathway for contamination of the vegetation. The resuspension factor for food-crop and animalproduct pathways is representative of conditions on farmland, which may be different from the resuspension factor for the inhalation exposure pathway. Farmland would be expected to be tilled and have soil generally looser than soil for the general residential exposure situations.

\subsubsection{Weathering and Retention}

Losses from plant surfaces are frequently represented by a weathering rate constant, $\lambda_{\text {wi }}$. Several processes may be involved. Some measurements of this process have implicitly included plant growth. Volatile materials may evaporate back into the air. If precipitation occurs, or there is heavy irrigation, physical washoff processes may be present. The default-rate constant in GENII, and in PATHWAY for all radionuclides other than iodines, is based on a weathering half time of 14 days. The value in RESRAD $\left(20\right.$ year $\left.^{-1}\right)$ is equivalent to a half-time of about 12.6 days. ECOSYS uses a half-time of 25 days; the ECOSYS model attempts to account also for dilution via plant growth in pasture grasses. When combined, the ECOSYS results are in the range of 10 to 16 days.

\subsubsection{Translocation from Plant Surface to Edible Portion}

The translocation factor indicates the fraction of total deposition to plant surfaces that is incorporated into edible parts of the plant. In most models, e.g., GENII, RESRAD, and CAP88-PC, a value of 1 is assumed for leafy vegetables and forage crops where the whole above-ground portion of the plant is eaten, and 0.1 for all other vegetation. The value of 0.1 is assigned on the basis of very little information and is assumed to be an upper bound.

Some other models attempt to treat foliar absorption with more rigor. The PATHWAY model assigns radionuclides to different foliar absorption categories: $\mathrm{Cs}$, Te, and Mo are assigned rate constants of $5.5 \times 10^{-3}$ day $^{-1}$; strontium and barium are assigned $1.0 \times 10^{-3}$ day $^{-1}$; and I is assigned $8.5 \times 10^{-3}$ day $^{-1}$. All others are assigned absorption rate constants of zero. The ECOSYS model has two categories: mobile and immobile. The ECOSYS mobile category has translocation factors of from 0.1 to 0.15 (similar to the GENII defaults), but for the immobile category, the translocation factor is set to 0.005 to 0.02 (the ranges are functions of time before harvest). Cs, I, $\mathrm{Mn}$, and $\mathrm{Te}$ are considered to be mobile, and $\mathrm{Sr}, \mathrm{Ba}, \mathrm{Zr}, \mathrm{Nb}, \mathrm{Ru}, \mathrm{Ce}$, and $\mathrm{Pu}$ are considered to be immobile.

There has been much research into agricultural chemicals applied to foliage, some of which has been performed with radioactive tracers (e.g., Tukey and Wittwer 1956; Tukey et al. 1956). Potassium and sodium were found to be rapidly absorbed and highly mobile. Phosphorus, sulphur, and chlorine were absorbed at a slower rate, but were also mobile and were transported at a rapid rate. Manganese, zinc, copper, and molybdenum were found to be slightly mobile. Calcium, strontium, barium, iron, and magnesium were readily absorbed but did not move out of the leaf to which they were applied. 
A sensitivity analysis on a PATHWAY-like model shows that the translocation terms are quite important, http://www.oita-nhs.ac.jp/ irpa10/CD-ROM/Full/00439_11_208sr13h00159.pdf. For deposition during the growing stage of agricultural plants, the parameters associated with contamination by foliar absorption were relatively influential in long-term contamination as well as short-term contamination.

A major study of the Biosphere Dose Conversion Factors being used for the Yucca Mountain analyses (LaPlante and Poor 1997) evaluated the sensitivities of various parameters used in the GENII-S formulation for plant uptake. Unfortunately, the translocation parameters were not varied in this study, and it is not possible to explicitly state how important they are. However, in most cases with active deposition occurring, the foliar interception pathway is usually dominant over the root-uptake pathway — primarily because conservatively high values are assumed for the translocation factor.

\subsubsection{Soil-to-Plant Uptake}

The transfer factor, also known as the concentration ratio, is the ratio of the concentration of an element in a plant of interest to the concentration in the source soil. The transfer factor applies to long-term, chronic exposures and is ideally measured at equilibrium. Transfer factors are used in risk assessments to estimate the amount of radioactivity that could be present in a food crop based on the calculated concentration in the source soil. By calculating the concentration in the food, the total intake can be estimated and a dose calculated as a result of the annual intake. In terms of radionuclides, the transfer factor is used to calculate how many becquerels per kilogram of soil are transferred to the edible dry plant product ( $\mathrm{Bq}$ per $\mathrm{kg}$ ). For vegetation, the units are $\mathrm{kg}$ soil $/ \mathrm{kg}$ edible dry plants.

Numerous studies have been undertaken to quantify transfer factors for specific chemical elements as a function of food type. These studies have been compiled in several publications. Most computer codes reference one or more of these compilations as the source of their transfer factors. Several frequently referenced compilations include the International Atomic Energy Agency's Technical Report Series \#364, Handbook of Parameter Values for the Prediction of Radionuclide Transfer in Temperate Environments (IAEA 1994). This document encompasses a wide variety of plant types and is the result of extensive background investigations. It is based on data compiled by the International Union of Radioecologists. A second frequently cited reference is the NUREG/CR-5512, Residual Radioactive Contamination From Decommissioning: Technical Basis for Translating Contamination Levels to Annual Total Effective Dose Equivalent (Kennedy and Strenge 1992) because of its large set of data and traceable references. Other references include the National Council on Ionizing Radiation and Protection (NCRP) Report \#123 (1996), Screening Models for Releases of Radionuclides to Atmosphere, Surface Water, and Ground, and the series of documents by Coughtrey and Thorne (1983), Radionuclide Distribution and Transport in Terrestrial and Aquatic Ecosystems, Vols. 16.

The transfer factors are empirically derived; they are based on measurements made for various chemical forms of the radionuclide on selected types of plant in selected soil types. Experimental data are not available for all elements for all food types. Frequently, a few 
measurements on a very limited number of plant types are used to infer a transfer factor for all crops. Often, when no referenceable documents are available, data are derived based on chemical groupings in the periodic table of the elements, such that chemically similar elements are assigned similar values.

The PATHWAY code uses rate constants to relate uptake from soil. However, these rate constants are estimated using the steady-state concentration ratios as the long-term value.

In researching transfer factors, it is necessary to fully understand the nature of the experiment or natural system in which it was measured. The type of plant, the type of soil, the quantity of naturally occurring chemical analogues in the soil, and the stage of growth all influence the amount of contaminant absorbed into the plant through the roots. In addition, it is important to know whether the concentration measurements are made in terms of wet or dry plant. Vegetation is a large percentage water, and the degree of turgor in the harvested plant has a strong influence in the measured concentration. The intent in most codes is to use a concentration ratio between dry soil and dry plant matter and to adjust to the full mass of the plant with a dry-to-wet mass ratio. When taking transfer factors from the literature, it is important to note whether the values are reported in wet or dry weight.

The National Council on Radiation Protection and Measurements developed a set of soil-to-plant transfer factors for screening applications (NCRP 1999), basing it largely on the International Atomic Energy Agency/International Union of Radioecologists (IAEA/IUR) publication. However, the NCRP specifically assigned uncertainty ranges to the parameters in the form of geometric standard deviations for assumed lognormal distributions. The assigned geometrical standard deviations (GSDs) ranged from 2.5 to 3.0. However, the CR values adopted by NCRP are described as being "close to the top of the measured range for most nuclides," with higher values used for sparsely vegetated soils. Because the screening intent was to be conservative, the actual uncertainty range could be larger (with a higher possibility of lower values.) Biwer et al. (2000) adopted the NCRP ranges for use in the RESRAD code. Beyeler et al. (1999) independently evaluated the CR values for the NUREG/CR-5512 model. They report GSDs ranging from a minimum of 2.47, based on 1250 measurements of 23 nuclides as reported by Sheppard and Evenden (1990), to as high as 9.5. Most nuclides were assigned the 2.47 default; interestingly, those radionuclides with some conflicting data often had higher GSDs than those with no data. It is apparent that there is a large potential variability in the CD values as a result of "numerous and complex underlying processes such as climate, growing conditions, plant metabolism, plant rooting traits, soil type, soil moisture, soil texture, and soil pH (Beyeler et al. 1999)."

Some models make additional assumptions involving root uptake and the surface soil layer. The GENII codes and RESRAD also allow the root uptake CR to be modified if not all of the plants' roots are in the contaminated soil layer. The GENII codes and RESRAD assume that uptake is directly proportional to the fraction of roots growing in the contaminated zone. In GENII, this is accomplished using an input root-penetration factor, usually set to 1.0 for surface contamination and a lower value for contamination covered with a clean surface layer. A similar approach is taken in RESRAD, which derives cover and depth modifying factors as a function of the thickness of the clean overburden above a contaminated layer. Biwer et al. (2000) investigated rooting depths for various types of plants, and suggested that for stochastic simulations this be 
varied uniformly from 0.3 to 4.0 meters. However, Biwer et al. did not consider the actual appropriateness of the assumption of linearity of uptake with root fraction.

A key assumption of the concentration-ratio approach is that the CR is a constant as a function of concentration; that is, the uptake is linear. This may not be true for contaminants that are essential nutrients. Non-linear responses may be possible if plants scavenge essential elements at low concentrations but maintain a homeostatic balance at higher soil concentrations (Sheppard and Sheppard 1985). There is generally little information to evaluate this concept except for a few radionuclides such as cesium, which mimics potassium, or strontium, which mimics calcium.

Root uptake is important for biologically active or mobile contaminants. Some contaminants are discriminated against by biological systems, and their root uptake is minimal. For these types of radionuclides, other mechanisms may be the dominant ones for vegetation contamination. Such mechanisms include simple physical contamination of the external surface of the plant, such as resuspension and deposition of dust or splashup of contaminated particles of soil during rain or irrigation episodes. The GENII, RESRAD, and PATHWAY codes account for resuspension and local deposition using a resuspension factor and a deposition velocity, coupled with a dry interception fraction. The ECOSYS model is similar, but uses an atmospheric mass-loading factor rather than a resuspension factor. The model of NUREG/CR-5512 does not describe any particular mechanism, but allows definition of an amount of surface soil to be associated with a mass of plant material. The rainsplash component is frequently neglected.

Some key biologically-active elements are modeled in a separate way through the use of specific activity models. The concentrations of tritium or carbon-14 in environmental media (soil, plants, and animal products) are usually assumed to be related to the specific activity (Becquerels of radionuclide per kilogram of soluble element) in the contaminating medium (air or water). The fractional content of hydrogen or carbon in a plant or animal product is then used to compute the concentration of tritium or ${ }^{14} \mathrm{C}$ in the food product under consideration. The hydrogen contents in both the water and the nonwater (dry) portion of the food product are used when calculating the tritium concentration. For computational simplicity, some codes do not explicitly state that this assumption is being made; an "effective" transfer factor may be employed. A soil-to-plant concentration ratio of about 5 is roughly equivalent to the specific-activity models for cases of chronic atmospheric deposition. However, this concentration ratio is not applicable to cases of initial soil contamination or irrigation contamination. For airborne releases, it is assumed that plants obtain all their carbon from airborne carbon dioxide and that animals obtain all their carbon through ingestion of plants. The transfer of ${ }^{14} \mathrm{C}$ from water to plants is difficult to model because plants acquire most of their carbon from the air. Most currently available models for ${ }^{14} \mathrm{C}$ uptake by plants from water use variations on specific-activity models relating the activity in the plants directly to the activity in irrigation water. This is extremely conservative in that it assumes that plants receive all of their carbon from water. The models in GENII and RESRAD are based on ratios of grams of ${ }^{14} \mathrm{C}$ to grams of total carbon in soil and a correction for the amount of carbon plants obtain from soil, although these two codes use different assumptions about the natural distribution of carbon in soils and water.

Specific activity models have been recommended for other radionuclides. Attributes that lead to this type of recommendation are long half-life, high mobility, biologically essential element, and 
massive isotopic dilution in the geosphere and biosphere. Iodine-129 and ${ }^{36} \mathrm{Cl}$ are some of the most critical radionuclides to consider in intermediate- and high-level nuclear-waste management, and both have these attributes. A model of ${ }^{36} \mathrm{Cl}$ was developed by the French national radioactive waste management agency ANDRA (Sheppard et al. 1997) to predict the radiological consequences to human dose receptors. The approach had three parts, a literature and benchmarking review of other ${ }^{36} \mathrm{Cl}$ models and programs, the development of a ${ }^{36} \mathrm{Cl}$ model suitable for ANDRA applications, and the measurement of stable chlorine concentrations and parameter values in the relevant landscape. A major issue was to resolve the degree to which specific-activity relationships were useful. Soil-to-plant and aquatic food pathways were modeled using specific-activity relationships. For subsequent transfers, the model used more traditional transfer factors. The use of the partial specific-activity model simplified the problem and made the model and parameters more general. This is especially relevant for transfers of ${ }^{36} \mathrm{Cl}$ because the concentrations of stable chlorine in the environment can vary substantially as a result of oceanic effects and local mineralization. The preliminary field study confirmed some of the key parameters to add confidence to the chosen parameter values and their ranges. A similar model could be developed for ${ }^{129} \mathrm{I}$.

It has been observed that the soil-to-plant concentration ratio is related to the solubility of radionuclides in soil water. As such, there should be a correlation between the transfer factor and the Kd (e.g., Sheppard 1985). Although several attempts have been made to use this correlation, there are enough confounding variables that this has not been overly successful.

\subsection{Simulation of Animal Products}

Pathways by which animal products may become contaminated include animal ingestion of plants, water, and soil. The concentration in feed plants is evaluated in a similar manner to the food-crop calculations as defined in Equations 5.4 and 5.5.

The concentration in an animal product at the time of harvest (slaughter, milking, or egg collection) is generally evaluated as follows:

$$
\mathrm{C}_{\text {hai }}=\mathrm{Fa}_{\mathrm{i}}\left[\mathrm{C}_{\mathrm{wi}} \mathrm{d}_{\mathrm{aw}} \mathrm{U}_{\mathrm{aw}}+\mathrm{C}_{\mathrm{ai}} \mathrm{d}_{\mathrm{as}} \mathrm{U}_{\mathrm{as}}+\sum_{\mathrm{f}=1}^{\mathrm{N}_{\mathrm{af}}} \mathrm{C}_{\mathrm{fi}} \mathrm{d}_{\mathrm{af}} \mathrm{U}_{\mathrm{af}}\right]
$$

where

$\mathrm{C}_{\text {hai }}=$ concentration of radionuclide $\mathrm{i}$ in animal product $\mathrm{a}$ at harvest of the animal product for a 1-year period $(\mathrm{Bq} / \mathrm{kg})$

$\mathrm{Fa}_{\mathrm{i}}=$ transfer coefficient that relates daily intake rate by an animal to the concentration in an edible animal product a $(\mathrm{Bq} / \mathrm{L}$ milk per $\mathrm{Bq} / \mathrm{d}$ for milk and $\mathrm{Bq} / \mathrm{kg}$ meat per $\mathrm{Bq} / \mathrm{d}$ for meat)

$\mathrm{C}_{\mathrm{wi}}=$ average concentration of radionuclide $\mathrm{i}$ in water consumed by animals for a year $(\mathrm{Bq} / \mathrm{L})$

$\mathrm{C}_{\mathrm{ai}}=$ average concentration of radionuclide $\mathrm{i}$ in soil consumed by animals for a year (Bq/kg dry soil)

$\mathrm{C}_{\mathrm{cfi}}=$ concentration of radionuclide $\mathrm{i}$ in animal feed type $\mathrm{f}$ at time of consumption for a 1 -year period $(\mathrm{Bq} / \mathrm{kg}$ wet weight) 
$\mathrm{d}_{\mathrm{aw}}=$ fraction of animal type a water intake that is contaminated (dimensionless)

$\mathrm{U}_{\mathrm{aw}}=$ daily water intake rate for animal type $\mathrm{a}(\mathrm{L} / \mathrm{d})$

$\mathrm{d}_{\mathrm{as}}=$ fraction of animal type a soil intake that is contaminated (dimensionless)

$\mathrm{U}_{\mathrm{as}}=$ daily soil intake rate for animal type a $(\mathrm{kg} / \mathrm{d})$

$\mathrm{N}_{\mathrm{af}}=$ number of feed types, $\mathrm{f}$, fed to animal type a

$d_{a f}=$ fraction of animal type a feed type $f$ intake that is contaminated (dimensionless)

$U_{a f}=$ daily feed intake rate for animal type a of feed type $\mathrm{f}(\mathrm{kg} / \mathrm{d})$.

The key parameter in Equation 5.11 is the feed-to-animal product transfer factor Fa. Nearly all computer codes (GENII, RESRAD, ECOSYS, PATHWAY) use such transfer factors. Like the soil-to-plant concentration ratio, this is an empirical parameter based on accumulated measurements. And, like the soil-to-plant ratio, many of the data are extrapolated from a range of experimental animals and chemical analogues. In actual application, the animal product transfer factor should be considered to be a function of season, stable element ingestion rates by the animal, and age, physical health, and state of lactation of the animal. These terms are usually neglected, and the transfer function is considered to be a constant. In addition, the potential for complexation of radionuclides in food, with attendant changes in bioavailability, are neglected, so that intakes with soil and water are treated the same as intakes of radionuclides incorporated into feed and fodder.

There are several ways that the empirical measurements of the animal-product transfer coefficient have been made. Ideally, they are a measurement made of animals in equilibrium with a known long-term rate of intake, which requires known concentrations in feed and known quantities of feed consumed. This situation rarely exists. Alternatively, equivalent information can be obtained from a single, acute feeding, when the total excretion of the contaminant from the animal is measured. However, the excretion has to be followed completely, or the truncated data may underestimate the full result. In many instances, data are gathered on animals in working agricultural systems where average contaminant levels may be reasonably well known. However, even in these cases, the actual intake by individual animals is only inferred. Finally, less-valuable results are derived from data about radionuclide concentrations of food products without a known relationship to intake, information regarding stable elements, transfer data of related elements, and collateral data from another species. As a result, transfer data for animal products may be unreliable for some radionuclides and have wide uncertainty bands for most.

The NCRP screening model (NCRP 1999) addressed the variability in the animal-product transfer factors. The NCRP assumed a lognormal distribution and assigned GSDs ranging from 1.2 to 2.8 , depending on the quality of available data. These ranges were adopted by Biwer et al. (2000) for use with RESRAD. However, the values chosen by NCRP were intended to be near the upper end of the distributions, and the GSDs omit some of the lower observations. The NCRP admits that there is a lack of good data for many of the radionuclides, and the ranges were assigned based on the authors' judgements. 


\subsection{Sensitivity of Key Plant and Animal Parameters}

It is difficult to make generalizations about the relative importance of the various input parameters to the equations for estimating radiation dose from ingestion of plants and animals. Which parameters are important depends on both the exposure scenario being considered and the pathway of exposure, as well as which radionuclide is being considered.

In general for groundwater sources being used for irrigation, foliar interception tends to be more important than root uptake (in large part because the translocation from plant surface to edible portion is assumed to be large). For most gamma emitters, dose from external exposure to radionuclides in soil may be a comparable magnitude to dose from the ingestion pathways. For most transuranics, inhalation (of resuspended soil) can be comparable with or larger than ingestion - although this may be because the contribution via rainsplash to plant surfaces is neglected.

LaPlante and Poor (1997) performed an extensive sensitivity analysis of the input parameters to the GENII-S code used in the generation of biosphere dose conversion factors (BDCFs) used in the environmental-impact assessment for the Yucca Mountain high-level waste (HLW) repository. In these analyses, LaPlante and Poor evaluated the BDCFs for 41 radionuclides and included 43 sampled parameters. The sensitivity-analysis results indicated that interception factors, food consumption rates, and irrigation parameters (rates and prior years of irrigation) were important to the estimated doses for most radionuclides. For biologically mobile contaminants, the soil-to-plant and feed-to-animal transfer factors are also important. The parameters related to plant contamination with soil (resuspension and redeposition) are of moderate to low importance (but, a different formulation of this process, such as rainsplash, might have resulted in greater importance.) However, because of limitations of the GENII-S code, not all of the parameters (in particular, the translocation factor) were evaluated. Another concept not directly evaluated was the relationship between the assumed surface soil mixing depth and root uptake.

Although limited, the results of LaPlante and Poor (1997) substantiate prior observations and provide insights into the avenues by which the parameters could be improved in the future. The observation that interception fraction ranks high is important. The interception, retention, and weathering parameters for irrigation deposition are not well known and are all areas of potentially fruitful research. The observation that, for the biologically-mobile radionuclides, the transfer factors are important indicates that if preliminary analysis shows very small transfer factors, then additional refinement may not be warranted. The general lack of information about the translocation factor indicates that it, too, is a profitable area for study.

\subsection{Recommendations Related to Modeling}

Several areas related to modeling long-term biosphere accumulation and transport have been highlighted above. These address the model for radionuclide accumulation in soil during irrigation, the interception and retention of radionuclides on plants, the transfer of radionuclides from soil and plant surfaces into the edible portions of plants, and the transfer of contaminants in animal feed to edible animal products. 
Models are needed that account for the actual physical processes that occur in surface soils. The model generally used to describe the surface-soil layer is very simple and may omit key processes. Verification measurements are needed that indicate whether the simple model is sufficient; if not, the measurements should indicate what other processes should be included. These may include leaching, complexation, and physical (colloidal, particulate, biological) transport.

Some information is available on interception of irrigation water by plant surfaces. This should be further evaluated, and, if appropriate, models that account for chemical speciation, water deposition rates, and/or leaf-surface physiology should be developed.

Soil-to-plant transfer factors for biologically mobile radionuclides need to be developed. For the other potential contamination mechanisms, splashup should be reviewed and incorporated as a contributing mechanism beyond resuspension. Translocation from surfaces to edible portions is potentially very important for vegetation other than leafy vegetables and pasture, and it is probably seriously over-conservative in current applications.

\subsection{Section 5 References}

Baes CF, and RD Sharp. 1981. Predicting Radionuclide Leaching from Root Zone Soil from Assessment Applications. CONF-81606, Oak Ridge National Laboratory, Oak Ridge, TN.

Beyeler WE, WA Hareland, FA Duran, TJ Brown, E Kalinina, DP Gallegos, and PA Davis. 1999. Residual Radioactivity from Decommissioning, Parameter Analysis, Draft Report for Comment, vol. 3. NUREG/CR-5512, Sandia National Laboratory, Albuquerque, NM.

Biwer BM, S Kamboj, JJ Cheng, E Gnanapragasam, C Yu, J Arnish, D LePoire, YY Wang, JP Butler, H Hartmann, and SY Chen. 2000. "Parameter Distributions for Use in RESRAD and RESRAD-BUILD Computer Codes," Attachment C to CYu, DLePoire, E Gnanapragasam, J Arnish, S Kamboj, BM Biwer, JJ Cheng, A Zielen, and SY Chen. 2000. Development of Probabilistic RESRAD 6.0 and RESRAD-BUILD 3.0 Computer Codes. NUREG/CR-6697, U.S. Nuclear Regulatory Commission, Washington, D.C. Available at: http://www.orau.com/ptp/pdf/5512-3.PDF

Bryce RW, CT Kincaid, PW Eslinger, and LF Morasch. 2002. An Initial Assessment of Hanford Impact Performed with the System Assessment Capability. PNNL-14027, Pacific Northwest National Laboratory, Richland, WA. Available at: http://www.hanford.gov/cp/gpp/sac/sacdocs.htm

Chaki S, and B Parks. 2000. UPDATED User's Guide for CAP88-PC, version 2.0, 402-R-00-004, U.S. Environmental Protection Agency, Washington, D.C.

Chamberlain AC. 1967. "Transport of Lycopodium Spores and Other Small Particles to Rough Surfaces." Proc. Roy. Soc. London A296:45-70. 
Coughtrey PC, and MC Thorne. 1983. Radionuclide Distribution and Transport in Terrestrial and Aquatic Ecosystems, a Critical Review of Data. Vols. 1-6. AA Balkema, Rotterdam.

International Atomic Energy Agency (IAEA), International Union of Radioecologists (IUR). 1994. "Handbook of Parameter Values for the Prediction of Radionuclide Transfer in Temperate Environments." IAEA, Tech. Rep. Series No 364, Vienna, Austria.

Jow H-N, JL Sprung, Ja Rollstin, LT Ritchie, and DI Chanin. 1990. "MELCOR Accident Consequence Code System (MACCS) Model Description.” NUREG/CR-4691, Nuclear Regulatory Commission, Washington, D.C.

Kennedy WE, Jr., and DL Strenge. 1992. "Residual Radioactive Contamination from Decommissioning: Technical Basis for Translating Contamination Levels to Annual Total Effective Dose Equivalent," vol. 1. NUREG/CR-5512, U.S. Nuclear Regulatory Commission, Washington, D.C.

LaPlante PA and K Poor. 1997. "Information and Analyses to Support Selection of Critical Groups and Reference Biospheres for Yucca Mountain Exposure Scenarios." CNWRa 97-00, Center for Nuclear Waste Regulatory Analyses, San Antonio, TX.

Leigh CD, BM Thompson, JE Campbell, DE Longsine, RA Kennedy, and BA Napier. 1992. "User's Guide for GENII-S: A Code for Statistical and Deterministic Simulations of Radiation Doses to Humans from Radionuclides in the Environment." SAND91-0561A, Sandia National Laboratories, Albuquerque, NM.

Muller H and G Prohl. 1993. "ECOSYS-87: A Dynamic Model for Assessing Radiological Consequences of Nuclear Accidents." Health Physics 64(3):232-252.

Napier BA. 2002. “GENII Version 2 User's Guide.” Pacific Northwest National Laboratory, Richland, WA. Available at http://www.epa.gov/rpdweb00/neshaps/models.htm

Napier BA, WE Kennedy Jr., and JK Soldat. 1980. PABLM - A Computer Program for Calculating Accumulated Radiation Dose from Radionuclides in the Environment. PNL-3209, Pacific Northwest Laboratory, Richland, Washington.

Napier BA, RA Peloquin, DL Strenge, and JV Ramsdell. 1988. "GENII - the Hanford Environmental Radiation Dosimetry Software System. Volume 1: Conceptual Representation, Volume 2: Users' Manual, Volume 3: Code Maintenance Manual," vols. 1-3. PNL-6584, Pacific Northwest Laboratory, Richland, WA.

Napier BA, DL Strenge, JV Ramsdell, Jr., PW Eslinger, and C Fosmire. 2002. "GENII Version 2: Software Design Document." Pacific Northwest National Laboratory, Richland, WA. Available at http://www.epa.gov/rpdweb00/neshaps/models.htm

National Council on Ionizing Radiation and Protection (NCRP). 1996. Screening Models for Releases of Radionuclides to Atmosphere, Surface Water and Ground. NCRP Report No. 123, Vol. I., Bethesda, MD. 
National Council on Ionizing Radiation and Protection (NCRP). 1999. "Recommended Screening Limits for Contaminated Surface Soil and Review of Factors Relevant to Site-Specific Studies.” NCRP Report No. 129, Bethesda, MD.

Nuclear Regulatory Commission (NRC). 2002. "Integrated Issue Resolution Status Report." NUREG 1762, Nuclear Regulatory Commission, Washington, DC.

Pinder III, JE, TG Ciravolo, and JW Bowling. 1988. "The Interrelationships Among Plant Biomass, Plant Surface Area, and the Interception of Particulate Deposition by Grasses." Health Physics 55:51-58.

Prohl G and FO Hoffman. 1993. "The Interception, Initial and Post Deposition-Retention by Vegetation of Dry and Wet Deposited Radionuclides." VAMP Terrestrial Working Group, International Atomic Energy Agency, Vienna, Austria.

Schreckhise RG. 1980. "Simulation of the Long-Term Accumulation of Radiocontaminants in Crop Plants." PNL-2636, Pacific Northwest Laboratory, Richland, WA.

Sheppard MI. 1985. "Radionuclide Partitioning Coefficients in Soils and Plants and Their Correlation." Health Physics 49:106-111.

Sheppard MI, DE Elrick and SR Peterson. 1997. "Review and Performance of Four Models to Assess the Fate of Radionuclides and Heavy Metals in Surface Soil." Can. Journal of Soil Science 77(3):333-344.

Sheppard MI, and WG Evenden. 1990. "Characteristics of Plant Concentration Ratios Assessed in a 64-Site Field Survey of 23 Elements." Journa Environ. Radioact. 11: 15-36.

Sheppard MI and SC Sheppard. 1985. "The Plant Concentration Ratio Concept as Applied to Natural U." Health Physics 48:494-500.

Shor RW, CF Baes III, and RD Sharp. 1982. "Agricultural Production in the United States by County: A Compilation of Information from the 1974 Census of Agriculture for Use in Terrestrial Food Chain Transport and Assessment Models." ORNL-5768, Oak Ridge National Laboratory, Oak Ridge, TN.

Strenge DL and TJ Bander. 1981. "MILDOS - A Computer Program for Calculating Environmental Radiation Doses from Uranium Recovery Operations.” NUREG/CR-2011, U.S. Nuclear Regulatory Commission, Washington, D.C.

Strenge DL, TJ Bander, and JK Soldat. 1987. "GASPAR II - Technical Reference and User Guide.” NUREG/CR-4653, U.S. Nuclear Regulatory Commission, Washington, D.C. 
Strenge DL and PJ Chamberlain. 1995. "Multimedia Environmental Pollutant Assessment System (MEPAS): Exposure Pathway and Human Health Impact Assessment Models." PNL-10523, Pacific Northwest Laboratory, Richland, WA.

Till JE and HR Meyer. 1983. "Radiological Assessment - A Textbook on Environmental Dose Analysis.” NUREG/CR-3332, U.S. Nuclear Regulatory Commission, Washington, D.C.

Tukey HB and SH Wittwer. 1956. "The Entry of Nutrients Into Plants Through Stem, Leaf And Fruit, as Indicated by Radioactive Isotopes.” Progress in Nuclear Energy Biological Sciences Series Six, pp. 106-114. McGraw-Hill, New York and Permagon Press, London.

Tukey HB, SH Wittwer, FG Teubner, and WG Long. 1956. "Utilization of Radioactive Isotopes in Solving the Effectiveness of Foliar Absorption of Plant Nutrients." International Conference on the Peaceful Uses of Atomic Energy, vol. 12: 138-148. United Nations, NY.

Wasiolek MA. 2001. Nominal Performance Biosphere Dose Conversion Factor Analysis. ANL-MGR-MD-000009 Rev. 01. Office of Civilian Radioactive Waste Management. Available at: http://m-oext.ymp.gov/html/prod/rms/MOL200101230123P.HTM

Whicker FW, and TB Kirshner. 1987. "PATHWAY: A Dynamic Food-Chain Model to Predict Radionuclide Ingestion After Fallout Deposition.” Health Phys. 52(6):717-737.

Yu C, AJ Zielen, JJ Cheng, DJ LePoire, E Gnanapragasam, S Kamboj, J Arnish, A Wallo III, WA Williams, and H Peterson. 2002. User's Manual for RESRAD Version 6. ANL/EAD-4, Argonne National Laboratory, Argonne, Illinois. Available at:

http://web.ead.anl.gov/resrad/home2/. 


\begin{tabular}{|c|c|}
\hline $\begin{array}{l}\text { NRC FORM } 335 \\
\begin{array}{l}(2-99) \\
\text { NRCM 1102, } \\
3201,3202\end{array} \\
\text { BIBLIOGRACLEAR REGULATORY COMMISSION } \\
\text { (See insfructions on the reverse) }\end{array}$ & \multirow[t]{2}{*}{$\begin{array}{l}\text { 1. REPORT NUMBER, } \\
\text { (Assianed by MRC, Add Vol., Supp., Rev., } \\
\text { and Addendum Numbers, if any.] } \\
\text { NUREG/CR-6825 } \\
\text { PNNL-14321 }\end{array}$} \\
\hline \multirow{3}{*}{$\begin{array}{l}\text { 2. TTLE AND SUBTTLE } \\
\text { Literature Review and Assessment of Plant and Animal Transfer Factors } \\
\text { Used in Performance Assessment Modeling }\end{array}$} & \\
\hline & DATE REPCRTPUUELISHED \\
\hline & $\begin{array}{l}\text { 4. FIN OR GRANT NUMAER } \\
\text { Y6469 }\end{array}$ \\
\hline \multirow{3}{*}{$\begin{array}{l}\text { 5. AUTHOR(S) } \\
\text { D.E. Robertson, D.A. Cataldo, B.A. Napier, K.M. Krupka, L.B. Sasser }\end{array}$} & \multirow{2}{*}{$\begin{array}{l}\text { 6. TYPE OF REPORT } \\
\text { Technical }\end{array}$} \\
\hline & \\
\hline & 7. PEFAOD COWERED (molusive Dates) \\
\hline \multicolumn{2}{|c|}{ 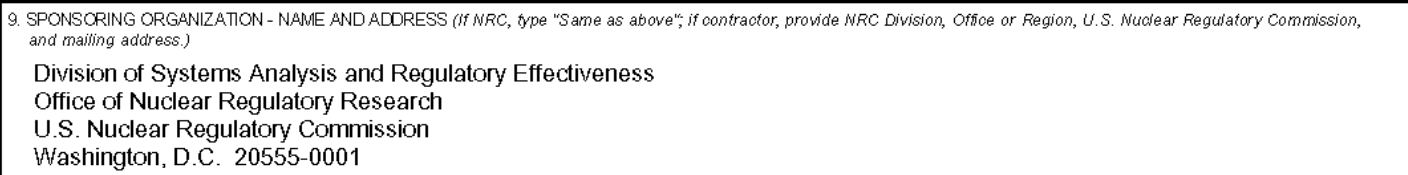 } \\
\hline \multicolumn{2}{|c|}{$\begin{array}{l}\text { A literature review and assessment was conducted by Pacific Northwest National Laboratory (PNNL) to update information on } \\
\text { plant and animal radionuclide transfer factors used in performance-assessment modeling. A group of } 15 \text { radionuclides was } \\
\text { included in this review and assessment. The review is composed of four main sections, not including the Introduction. Section } \\
2.0 \text { provides a review of the critically important issue of physioochemical speciation and geochemistry of the radionuclides in } \\
\text { natural soil-water systems as it relates to the bioavailability of the radionuclides. Section } 3.0 \text { provides an updated review of the } \\
\text { parameters of importance in the uptake of radionuclides by plants, including root uptake via the soil-groundwater system and } \\
\text { foliar uptake due to overhead irrigation. Section } 3.0 \text { also provides a compilation of ooncentration ratios (CRs) for soil-to-plant } \\
\text { uptake for the } 15 \text { selected radionuclides. Section } 4.0 \text { provides an updated review on radionuclide uptake data for animal } \\
\text { productes related to absorption, homeostatic control, approach to equilibration, chemical and physical form, diet, and age. } \\
\text { Compiled transfer ooefficients are provided for cow's milk, sheep's milk, goat's milk, beef, goat meat, pork, poultry, and eggs. } \\
\text { Section } 5.0 \text { discusses the use of transfer ooefficients in soil, plant, and animal modeling using reglatory models for evaluating } \\
\text { radioactive waste disposal or decommissioned sites. Each section makes specific suggestions for future research in its area. }\end{array}$} \\
\hline \multirow{6}{*}{$\begin{array}{l}\text { physioochemical speciation } \\
\text { geochemistry } \\
\text { bioavailability } \\
\text { radionuclide uptake } \\
\text { concentration ratio } \\
\text { transfer coefficient } \\
\text { performance assessment modeling }\end{array}$} & $\begin{array}{c}\text { 13. AVAILABILITY STATEMMENT } \\
\text { unlimited }\end{array}$ \\
\hline & 14. SECURITY CLASSIFICATION \\
\hline & $\begin{array}{l}\text { (This Page) } \\
\text { undassified }\end{array}$ \\
\hline & $\begin{array}{l}\text { This Report } \\
\text { undassified }\end{array}$ \\
\hline & 15 NUMAER OF PAGES \\
\hline & 16. PRICE \\
\hline
\end{tabular}

